marcelo2867@gmail.com

UNIVERSIDADE DE SÃO PAULO

FACULDADE DE FILOSOFIA, LETRAS E CIÊNCIAS HUMANAS

MARCELO FERRAZ DE PAULA

\title{
POESIA E DIÁLOGOS NUMA ILHA CHAMADA BRASIL
}

São Paulo

2012 


\section{MARCELO FERRAZ DE PAULA}

Poesia e diálogos numa ilha chamada Brasil

Tese apresentada à Faculdade de Filosofia, Letras e Ciências Humanas da Universidade de São Paulo para obtenção do título em doutor em Estudos Comparados de Literaturas de Língua Portuguesa.

Orientador: Prof. Dr. Mário César Lugarinho

São Paulo

2012 
Nome: PAULA, Marcelo Ferraz de

Título: Poesia e diálogos numa ilha chamada Brasil

Tese apresentada à Faculdade de Filosofia, Letras e Ciências Humanas da Universidade de São Paulo para obtenção do título de doutor em Estudos Comparados de Literaturas de Língua Portuguesa.

Aprovado em:

\section{Banca Examinadora}

Prof. Dr.

Julgamento:

Instituição:

Assinatura:

Prof. Dr. Instituição:

Julgamento: Assinatura:

Prof. Dr. Instituição:

Julgamento: Assinatura:

Prof. Dr. Julgamento: Instituição: Assinatura: 


\section{Agradecimentos}

Ao meu orientador, professor Mário César Lugarinho, pela confiança no trabalho, constante incentivo e amizade generosa.

Aos professores Jorge Valentim e Emerson da Cruz Inácio, pelas valiosas contribuições durante o exame de qualificação e, ao segundo, pelo decisivo apoio que vem desde muito antes do início do projeto.

Aos professores da faculdade de letras da USP, cada um com suas singularidades e visões moldaram, com lições e exemplos, os rumos da minha formação. Especialmente aos doutores Vagner Camilo, Jaime Ginzburg, Viviana Bosi, José Antônio Pasta Junior, Benjamin Abdala Junior, Paulo Motta Oliveira e Jorge de Almeida, meu respeito e gratidão.

Ao Fernando Medeiros, sempre prestativo e atencioso, pelo desprendido socorro que ofereceu na parte final do trabalho.

Ao Eloy e ao Fagner, sempre presentes com conselhos e ensinamentos que ultrapassam os limites deste trabalho mas que aparecem nele a todo instante.

Aos amigos que, com suas sugestões, indagações ou simples disposição a ouvir foram imprescindíveis durante a elaboração deste projeto: Ivana, Renata, Eduardo, Adriana, Ligia, Daniel, Nancy, Brunna, Minoti, e tantos outros.

À Jaque, pelo sentido que oferece a tudo isto. 
"A República Federativa do Brasil buscará a integração econômica, política, social e cultural dos povos da América Latina, visando à formação de uma comunidade latino-americana de nações"

Constituição da República Federativa do Brasil 1988. Art. $4^{\circ}$, parágrafo único. 
PAULA, M. F. Poesia e diálogos numa ilha chamada Brasil. Tese de doutoramento. Faculdade de Filosofia, Letras e Ciências Humanas, São Paulo, 2012.

\section{Resumo}

A veiculação de uma perspectiva comunitária voltada para a aproximação/integração dos países latino-americanos recebeu destacada importância nas produções culturais brasileiras das décadas de 1960 e 1970. Especialmente no âmbito das manifestações artísticas, novas articulações em torno de uma identidade latino-americana surgiam na pauta dos debates político-culturais. A partir deste contexto, o presente trabalho visa refletir sobre a importância do ideal americanista para a poesia brasileira do período, dando destaque à produção poética de Ferreira Gullar e Thiago de Mello. A escolha por estes dois autores justifica-se pela intensidade e dramaticidade com que suas obras encarnaram as esperanças e contradições da época, tanto no que se refere aos dilemas formais inerentes a uma concepção poética disposta a atuar politicamente na realidade social, transformando-a, como no espaço que oferecem à representação de uma união solidária entre os países da América Latina. A partir da leitura de seus poemas buscamos matizar a posição da fulguração americanista dentro de um projeto político e estético mais amplo, bem como os lugarescomuns que acompanham sua concretização formal. Damos especial atenção aos eventos e personagens que, a nosso ver, catalisam o viés comunitário daquele período, tornando-se protagonistas de vários poemas e confundindo-se simbolicamente com o próprio desejo de aproximação solidária: a Revolução Cubana, a celebridade de Pablo Neruda e Che Guevara e o exílio dos poetas brasileiros em países da América Latina, destacadamente no Chile de Allende, onde testemunharam a euforia construtiva e a frustração traumática do projeto socialista. Por fim, propomos um balanço crítico das limitações desta tendência, sem desconsiderar a importância de tais ensaios supranacionais em um país pouco sensível ao diálogo com culturas e sociedades afins, como tem confirmado a história brasileira. Encerramos a pesquisa vasculhando os escombros do discurso americanista nas obras mais recentes dos poetas - De uma vez por todas (1996) e Campo de Milagres (1998), de Thiago de Mello, e Muitas Vozes (1999) e Em alguma parte alguma (2010) de Ferreira Gullar - publicadas na última década do último século e na primeira do século corrente. Num contexto marcado pela consolidação da chamada globalização neoliberal e de crise dos discursos utópicos - que sustentavam a aspiração comunitária - procuramos identificar e examinar novos arranjos discursivos e, a partir deles, sugerir o lugar (ou não-lugar) da América Latina no rol de preocupações da poesia brasileira contemporânea.

Palavras-chave: Ferreira Gullar, Thiago de Mello, comunitarismo, América Latina, poesia brasileira. 


\title{
PAULA, M. F. Poetry and dialogues on an island called Brazil. Tese de doutoramento. Faculdade de Filosofia, Letras e Ciências Humanas, São Paulo, 2012.
}

\begin{abstract}
The propagation of a community perspective toward the approach/integration of Latin American countries received outstanding importance in the brazilian cultural productions of the 1960s and 1970s. Especially in the context of artistic manifestations, new articulations around a "Latin American identity" appeared on the agenda of political and cultural debates. This work aims to reflect on the importance of americanist ideal for brazilian poetry of the period, highlighting the poetic production of Ferreira Gullar and Thiago de Mello. The choice of these two authors is justified by the intensity and drama that his works embody the hopes and contradictions of the era, both in relation to the formal dilemmas inherent in a poetic conception willing to act politically on the national reality, transforming it, and in the space that offers the representation of a union and solidarity between the countries of Latin America. From his poems, then, we can gradate the position of the Americanist glare within a broader political and aesthetic project, as well as the platitudes that accompany its formal implementation. We give attention to the events and characters that, in our view, leverages the communitarian bias of those poets, becoming protagonists of several poems and symbolically mingling with their own desire for closer solidarity: the Cuban Revolution, the celebrity of Pablo Neruda and Che Guevara and the exile of the poets under study in Latin American countries, notably in Allende's Chile, where they witnessed the constructive euphoria and the traumatic frustration of the socialist project. Finally, we propose a critical review of the mistakes and limitations of this trend, without disregarding the importance of these supranational trials in a country not very sensitive to dialogue with cultures and societies alike, as it has confirmed the Brazilian history. We ended the research combing the rubble of the Americanist discourse in more recent works of the poets - De uma vez por todas (1996) and Campo de Milagres (1998), of Thiago de Mello, and Muitas Vozes (1999) and Em alguma parte alguma (2010) of Ferreira Gullar published in the last decade of last century and in the first of the current century. In a context marked by the consolidation of the so-called neoliberal globalization and of crisis of the utopian discourse - that supported the communitarian aspiration - we tried to identify and examine the new discursive formulations and, from them, suggest the place (or non-place) of Latin America in the list of concerns of the contemporary Brazilian poetry.
\end{abstract}

Key words: Thiago de Mello; Ferreira Gullar; communitarianism; Latin American; Brazilian Poetry. 
marcelo2867@gmail.com

\section{SUMÁRIO}

Introdução..

\section{Capítulo 1: As bases de um diálogo}

1.1- O Brasil dos anos 50: euforia política e drama poético .......................................................... 19

1.2- As máscaras e os espelhos: o escopo da latinidad na militância poética.................................. 24

1.3- Do drama linguístico ao engajamento poético: notas sobre duas poéticas que se cruzam ........ 30

1.4- Engajamento, PCB e América Latina ................................................................................ 43

\section{Capítulo 2- Eixos de uma poética americanista}

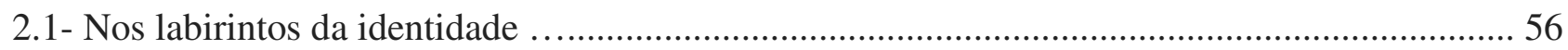

2.2- Thiago de Mello e o "Interlocutor Geral" .................................................................................... 73

2.3- A Revolução Cubana e a poesia brasileira ....................................................................... 85

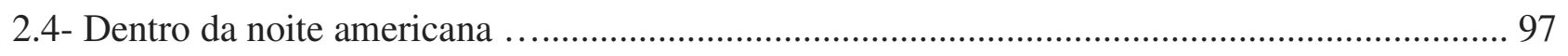

\section{Capítulo 3 - A América vista do exílio}

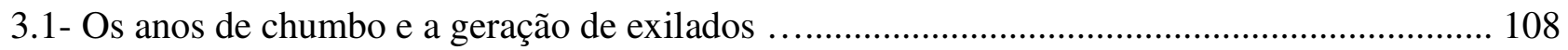

3.2- A experiência chilena: ascensão e queda ....................................................................... 126

3.3- O Poema Sujo e a São Luís latino-americana ................................................................... 142

3.4- Thiago de Mello: a língua do exílio e a língua do diálogo ............................................... 150

\section{Capítulo 4- De volta à ilha}

4.1- Saudades da utopia ou vergonha de um dia ter sonhado? ............................................... 159

4.2- Globalização e América Latina, memória e resistência .................................................... 167

4.3- De uma vez por todas, América ............................................................................... 171

4.4- Entre as ruínas da memória, ruínas de América .................................................................... 184

Considerações finais ........................................................................................................ 194

Referências Bibliográficas ....................................................................................... 199 



\section{Introdução}

A representação simbólica de um Brasil insular encontra fundamento no processo históricocultural de formação do país. De um lado, o Brasil está distante da antiga metrópole portuguesa, e dos países africanos com os quais compartilha o idioma, por conta da extensão abismal do oceano Atlântico. Por outro lado, permanece à deriva numa América Latina onde predomina a fala hispânica das nações vizinhas, sendo o idioma um muro não menos traumático para a inserção do país em um ideal americanista. Não por acaso, estes dois horizontes - a América Latina e os países de língua (oficial) portuguesa - se constituem como espaços privilegiados, no caso do Brasil, para uma aproximação de fundo comunitário, devido a convergências históricas, sociais, econômicas e de certa afinidade cultural capaz de justificar um contato mais duradouro e proveitoso (ABDALA, 2003, p. 67).

$\mathrm{Na}$ configuração do discurso identitário brasileiro, a predestinada imagem da ilha deixa revelar, conforme sugere Eduardo Lourenço (1999) ao pensar os trânsitos Brasil-Portugal, fortes indícios de soberba e de uma ilusória auto-suficiência por parte dos brasileiros. A conformidade, quase o orgulho do isolamento, revela certo ocultamento do passado e negligência em relação ao futuro, este porvir automático já contido nos germens da identidade brasileira, frequentemente acomodada no mito do "país do futuro", discurso do qual podemos deduzir facilmente a mascarada certidão de "um país sem passado". Mas do mesmo modo que indica uma inverossímil sensação de “autonomia natural” (LOURENÇO, 1999, p. 180) a metáfora da ilha também pode ser lida como indício de isolamento e solidão. Gera incômodo, exige saídas, diálogos, pontes.

Em um momento não muito distante da história brasileira, mais precisamente durante as décadas de 1960 e 1970, o desejo de superação da condição insular esteve em grande voga no debate cultural brasileiro, com abundantes exemplos na música popular, nas artes plásticas e, como tentará demonstrar este trabalho, na poesia. No horizonte daquela geração fulgurava, como um sol cheio de promessas, uma América Latina subdesenvolvida, explorada, desigual, farta de afinidades irrecusáveis e prenhe de uma ação política comum, coletiva. A memória compartilhada do passado colonial era atualizada no discurso político da época, que denunciava um presente de dependência econômica e penúria causada pela ação imperialista. Ativada por um discurso inflamado, o ideal de uma América Latina unida, a superar a arbitrariedade de suas fronteiras impostas por mãos estrangeiras, era adequado à proposta revolucionária que mirava um futuro comum de libertação e justiça social. Era, sem dúvida, um discurso de base abertamente esquerdista, promulgado por 
intelectuais adeptos ou simpatizantes das propostas socialistas que naquele período, ocupavam algumas das fileiras mais destacadas do pensamento latino-americano, inclusive no Brasil (SCHWARZ, 1978, p. 62).

Tomando como ponto de partida algumas das manifestações poéticas do período, a presente investigação se propõe a analisar a participação da poesia brasileira na difusão e construção de uma identidade latino-americana, defendendo a tese de que a aspiração americanista foi tema dos mais relevantes para a lírica brasileira nos anos 1960 e 1970 e que, por conta disso, merece estudo mais denso e detalhado sobre a natureza e os resultados alcançados por esta linhagem literária. Por isso tentamos examinar ao longo das próximas páginas as potencialidades estéticas abertas pelo horizonte comunitário, buscando compreender as pontes imaginárias e utópicas erguidas em nome da latinidade, bem como questionando a inegável fragilidade de suas estruturas.

Elegemos como objeto central de análise a produção literária de dois dos mais atuantes poetas brasileiros da segunda metade do século XX: o maranhense Ferreira Gullar e o amazonense Thiago de Mello. Trata-se de escritores que viveram intensamente a esperança da transformação social impulsionada pela palavra poética e sofreram as contradições e, em certa medida, o fracasso deste projeto. Por isso a irregularidade no rigor de suas produções não diminuir a relevância de um estudo mais sistematizado de suas expressões, suas crenças, inovações e, por que não, de seus equívocos. Encontramos nessas duas poéticas uma presença abundante de temas relacionados à vertente americanista aqui discutida: ora de maneira indireta, por meio de poemas que resgatam paisagens, personagens, eventos de países da América Latina, ora proclamando diretamente um sentimento identitário voltado para ação conjunta, sustentado pela crença numa "pátria grande" e na defesa figurativa da integração continental como estratégia libertária.

A escolha de uma abordagem comparativa coloca em questão semelhanças e diferenças entre os universos poéticos mencionados. No campo das semelhanças, cabe destacar a trajetória paralela dos autores, contemporâneos no sentido mais profundo do termo. Começaram a publicar em inícios dos anos 1950 e iniciaram uma publicação enquadrada no que se convencionou denominar de "arte engajada" durante a década de 1960. Vale ressaltar que no decorrer deste trabalho sempre que utilizarmos a expressão "engajamento" - daqui para frente escrita sem as aspas - ou suas variantes de sentido similar ("poesia comprometida", "poesia participante”), estaremos nos referindo à opção formal destas obras em não omitir ou ocultar as posições políticas de seus autores, assim como sua disposição mais ou menos declarada em participar ativamente da práxis social, procurando imprimir no trabalho artístico uma função de combate e de desmascaramento das forças hegemônicas (ABDALA, 2007, p. 96). 
marcelo2867@gmail.com

Além da adesão ao engajamento, ou justamente por conta dele, os poetas em estudo também foram vítimas da ditadura brasileira, sofrendo com perseguições, prisões e, posteriormente, exilando-se em países latino americanos, momento de fundamental importância para as representações da latinidade em suas obras. Outro ponto explorado no decorrer desta pesquisa e que justifica a escolha destes poetas, e não outros que também se dedicaram ao tema, é a longevidade de suas produções. Ambos continuaram escrevendo na década de 1990, momento em que a tendência americanista caía em desuso na literatura, aparentemente ficando confinada ao superado contexto de dualidade ideológica da Guerra Fria. Refletir sobre os caminhos trilhados nesta nova etapa e discutir as alterações desenvolvidas pelos poetas no tratamento dado à temática latino-americana nas obras mais recentes são objetivos que estas duas poéticas permitem realizar com certa desenvoltura.

No entanto, tais coincidências só ganham seu verdadeiro brilho quando utilizadas para iluminar os caminhos contrários que os autores escolheram para elaborar suas obras poéticas. Ferreira Gullar ficará eternizado na literatura brasileira como poeta de exuberante ousadia formal, experimentalista, radical, inquieto em seus motivos. É precisa a afirmação de João Luiz Lafetá (2007a) que o considera um verdadeiro "repórter do nosso tempo", por se comportar como uma espécie de para-raios de todas as polêmicas e crises literárias que agitaram o cenário poético brasileiro da segunda metade do último século. Da mais obstinada desfiguração da linguagem em seu primeiro livro, A Luta Corporal (1954), passando pela experiência vanguardista do concretismo e do neoconcretismo, até chegar à poesia popular e sectária dos versos de cordel e, enfim, à maturidade daquilo que Alfredo Bosi (2004) define como "memorialismo engajado", ilustração precisa de uma linguagem visceral evocada para dar vida às vertigens da memória, mescladas com uma pungente aspiração revolucionária. Ferreira Gullar atravessa as questões sociais e os debates estéticos mais controversos do período, logo expande os modelos aos quais se entrega, sempre com um temperamento poético muito próprio e certa fluidez na visão de mundo e de poesia que, mesmo oscilando, mostram-se fortes e ordenados.

Thiago de Mello é exemplo de postura oposta. Nunca foi poeta de extravagâncias formais, pelo contrário, quando erra é pelo prosaísmo excessivamente simplificado, nunca pela petulância esnobe ou pelos modismos cultuados. Sua obra corresponde a uma regularidade quase obsessiva de temas e formas, nos quais a técnica poética está, pelo esforço da própria voz criadora, ocultada num plano distante, livre de esteticismos ou hermetismos gratuitos. A carga dramática de seus versos é depurada e escondida por uma fachada de extrema comunicabilidade. É modelo de uma poesia genuína, mais próxima da disciplina proporcionada pela confiança na expressão do que à fúria trágica da linguagem moderna. Predomina a simplicidade dos versos metrificados tradicionais - 
marcelo2867@gmail.com

ainda que sem purismos de linguagem - de aparência espontânea e fluente. A rima é usada com certa recorrência e suas cadências oscilam entre uma musicalidade bastante elementar e um prosaísmo mais ou menos intencional, disposto a estabelecer uma cumplicidade com o leitor, gerando uma cadência simples e contínua.

Estas especificidades, como não poderia deixar de ser, se desdobram na recepção crítica das obras estudadas. Ferreira Gullar possui uma fortuna crítica sólida, na qual se destacam ensaios de críticos como Alfredo Bosi (2004), João Luiz Lafetá (2007), Alcides Villaça (1984) e Eleonora Ziller Camenietzki (2006), além de inúmeras resenhas, teses e artigos acadêmicos que acompanham as diversas etapas de sua trajetória, aspectos de seu estilo ou comentam com certa minúcia seus livros mais celebrados. Ao contrário disso, a bibliografia em torno da obra de Thiago de Mello é incipiente, contando com poucos artigos esparsos que não chegam a formular uma interpretação global da obra e tampouco se detém numa leitura mais detida de seus poemas, oscilando entre a bajulação acrítica do autor e o crivo performático da crítica demolidora.

O desequilíbrio no estágio da discussão acadêmica sobre os autores lança alguns desafios para o exame comparativo aqui proposto. Ainda que a discussão se concentre num tema específico, no caso a presença da América Latina, seria ilícito ignorar o lugar desta temática na poética de cada um. Neste sentido, fica patente um certo desnível entre o prestígio dos dois poetas; desnível que o trabalho ao invés de mascarar, procurou debater sem recorrer a preconceitos e leituras automatizadas. O cuidado que tentamos tomar é para que o maior reconhecimento da crítica pela poesia de Gullar, sua rápida assimilação pelo cânone literário e o consenso público frente à importância de sua obra, não ofusquem o outro objeto da comparação, a obra menos consistente e aplaudida de Thiago de Mello.

No que se refere, portanto, à contribuição para a fortuna crítica destes autores, nosso estudo reconhece uma inevitável demarcação crítica. As considerações sobre Ferreira Gullar, por serem apoiadas em pesquisas anteriores, reunidas numa respeitável fortuna crítica, procuram avançar em direção a um tópico importante de sua obra que, acreditamos, ainda não havia sido explorado a fundo pelos trabalhos anteriores. Graças ao avanço das discussões, temos subsídios suficientes para tomar alguns pressupostos e avançar o máximo possível na discussão, articulando a temática latinoamericana e os poemas no qual ela se concretiza com as principais facetas do poeta maranhense.

No caso de Thiago de Mello, a ausência de um alicerce crítico exige um constante movimento especulativo. Sentimos a necessidade de formular uma apreciação crítica e uma sugestão a respeito do conjunto da obra. O leitor notará que algumas hipóteses de leitura lançadas ao conjunto da obra de Thiago de Mello se reconhecem bastante provisória e sua função, além de 
marcelo2867@gmail.com

contribuir para futuros estudos que encarem o desafio de uma empreita totalizante da poesia do autor, é a de construir um conhecimento elementar a respeito desta obra; uma base mínima que permita um avanço seguro e proveitoso pelo tema da latinidade, que julgamos central em sua poética.

Para desenvolver tais questões, o estudo está organizado em quatro capítulos que seguem uma ordem cronológica bastante flexível, antecipando ou retomando informações cada vez que o movimento da reflexão assim o exigiu. Desse modo, percorremos os principais acontecimentos da segunda metade do século XX no Brasil e na América Latina, a partir da leitura de alguns poemas estratégico que evocam o desejo de diálogo entre os países do continente.

Partimos do momento de inauguração das duas poéticas estudadas, em inícios da década de 1950. Em seguida discutimos com mais delonga a decisiva passagem dos autores para uma poesia de fundo participativo, ligada a outros segmentos do movimento social da época, como os Centro Populares de Cultura (CPCs) e o próprio Partido Comunista Brasileiro (PCB). Na década de 1970 destacamos o exílio dos autores em países latino-americanos e, por fim, chegamos ao final do século: primeiro uma breve etapa de transição da euforia coletiva ao drama individual, culminando, nos anos 1990, na crise final do comunismo soviético, seguida pela ascensão da economia neoliberal e a consolidação daquela que seria sua faceta mais abrangente, o então denominado processo de globalização.

No primeiro capítulo fazemos uma apresentação geral dos poetas estudados, comentando as características de seus primeiros livros. Em sintonia com esta rápida familiarização com os autores, investigamos as condições históricas que permitiram ao pensamento americanista aflorar com grande relevância na arte brasileira durante a década de 1960. Fazemos também um breve panorama dos debates teóricos em torno da latinidade, do surgimento do termo a sua abundante mobilização durante o momento estudado, ressaltando sempre o papel problemático do Brasil nos sistemas interpretativos da América Latina.

Para esclarecer o destacado papel ocupado pelo comunitarismo na poesia brasileira dos anos 1960, discutimos o contexto da Guerra Fria e seus desdobramentos na cultura e na política nacional, relacionando-os sempre com os debates em torno da forma literária, das vanguardas poéticas e do papel do intelectual na sociedade, aquela altura marcados por grandes pressões sobre os artistas e esperanças de que ocorressem mudanças estruturais no país. Seguindo uma perspectiva crítica que busca conjugar o debate sobre a poesia e seus elementos técnicos e formais com os impasses históricos que a permeiam, tentamos entender as condições que criaram um terreno fértil para uma guinada de parte da poesia brasileira. Saindo de um nacionalismo tácito para uma perspectiva de 
solidariedade comunitária, na qual se destacava um esforço de diálogo com a América Latina, seus artistas, suas histórias e suas paisagens, elevados com uma simplicidade por vezes ingênua ao enfatizado rótulo da inequívoca fraternidade, sob o duvidoso lema do "tudo nos une, nada nos separa"

No segundo capítulo a abordagem é mais vertical. A partir da leitura detalhada de alguns poemas paradigmáticos, analisamos os pressupostos identitários veiculados por estas obras, salientando a diferença de abordagem da latinidade nas obras de Thiago de Mello e Ferreira Gullar e avaliando o resultado final alcançado por cada um. São levados em consideração os tratamentos dados às paisagens do continente e aos personagens resgatados em alguns dos poemas da época. Também é comentado o diálogo, explícito ou implícito, com outros artistas latino-americanos e o modo como estes elementos convergem para um projeto de aproximação entre os países latinoamericanos, com todos os complicadores de um projeto político que busca ser materializado na literatura. Algumas categorias de análise são retomadas e confrontadas, como a presença do pensamento utópico, o didatismo programático, a encenação mítica da união continental, o engajamento, dentre outros pontos de grande relevância para se compreender as potencialidades e os limites das manifestações da época. Alguns dos temas mais caros ao pensamento latinoamericano são apresentados e os exemplos colhidos na obra de Thiago de Mello e Ferreira Gullar são comparados: o diálogo com o poeta chileno Pablo Neruda, o épico efeito político e simbólico da Revolução Cubana, a figura jovial e, depois, o martírio de Che Guevara, são alguns dos polos que catalisam a dimensão comunitária, de viés latino-americano, destas poéticas e que são analisados à luz de um comparatismo ativo.

Já no terceiro capítulo são examinadas as produções escritas durante os anos de exílio dos poetas em países da América Latina, no início da década de 1970. Resgatamos trabalhos teóricos que analisam os impactos da experiência do exílio e de que forma eles se refletem na produção destes poetas, em especial no que tange ao ideal americanista. Interessa-nos compreender como a defesa do diálogo e da aproximação continental será afetada pela vivência prolongada (e forçada) dos poetas em países da América Latina. Soma-se à experiência negativa do exílio o conturbado momento histórico que presenciaram nestes países, ameaçados por golpes de estado e em constante tensão política. O evento mais sintomático desta fase foi, sem dúvida, o testemunho do golpe militar chileno e suas trágicas consequências para os diversos militantes exilados no país durante o governo de Salvador Allende, dentre eles, claro, Thiago de Mello e Ferreira Gullar.

1 Frase atribuída ao presidente argentino Sáez Peña em discurso proferido em visita ao Brasil, no início do século XX. A sentença seria retomada por personagens símbolos do ideal americanista na década de 1960, aparecendo, por exemplo, em discursos de Pablo Neruda e Che Guevara, com seu efeito alargado para sintetizar uma vocação latinoamericana para a integração. 
marcelo2867@gmail.com

Tratamos, pois, de acompanhar as representações poéticas que os autores fazem do golpe. Poemas importantes do período, nos quais é salientada a violência e a brutalidade das forças armadas, brotando em versos de fundo testemunhal a solidariedade a Allende e o efeito traumático da experiência ali vivida, a qual nos parece decisiva para a produção futura de ambos os poetas. Encadeados com este tema, está a análise do principal livro de Ferreira Gullar, o Poema Sujo (1976), e suas relações com o exílio, com a memória e com a América Latina, este último tema ainda pouco explorado pela crítica especializada. No caso de Thiago de Mello, destacamos as estratégicas literárias que imprime em sua obra com o intuito de diminuir a distância - inclusive linguística - entre o Brasil e os países latino-americanos, proposta constante em sua poesia e complementada com o ofício de tradutor contumaz da poesia hispano-americana.

Por fim, no quarto e último capítulo, adentramos pela década de 1990, mas não sem antes acompanhar uma rápida etapa de transição observada na produção dos autores nos anos 1980, quando retornam do exílio. Mormaço na Floresta (1984) e Num campo de margaridas (1986), de Thiago de Mello, e Na vertigem do dia (1980) e Barulhos (1987), de Ferreira Gullar, abrem caminho para uma reavaliação do trabalho criativo dos autores, resultando num impasse entre a produção mais abertamente engajada que trilharam nos anos anteriores e as novas perspectivas poéticas abertas por um novo cenário, no qual o espaço antes destinado a cantar o sonho de uma América livre e unida torna-se cada vez mais restrito, com uma incômoda fachada de anacronismo.

É momento de encarar algumas apostas políticas e estéticas que se mostraram equivocadas e rearticular a voz poética para uma nova resistência, que será a tônica de seus últimos livros, publicados no fim do século XX: Muitas Vozes (1999) de Gullar, e De uma vez por todas (1996) e Campo de Milagres (1998), de Thiago de Mello - além do mais recente Em alguma parte alguma (2010), de Gullar, lançado já na reta final de elaboração desta pesquisa, mas mencionado em um ou outro ponto da análise. Novamente os caminhos utilizados pelos autores serão opostos, merecendo uma mediação crítica que leia estes livros como respostas díspares ao novo estágio de crise utópica e esvaziamento da ação política.

Resta, pois, ao fim do trabalho, indagar as contribuições das obras aqui estudadas para se pensar as relações entre esta ilha chamada Brasil e os países hispano-americanos. Vasculhar o espaço possível do diálogo e a atualidade destas obras num momento de disforia e elevada desconfiança frente aos arranjos comunitários, em grande parte sufocados pela urgência dos acordos estritamente comerciais priorizados pela globalização neoliberal, verificados, por exemplo, nas principais conquistas do Mercosul ou da Unasul, órgãos em que a solidariedade cultural e o mútuo conhecimento entre os países membros são propostas marginais, quase decorativas, em comparação 
marcelo2867@gmail.com

à alardeada urgência de fortalecimento de mercados.

No campo inverso, mas não menos importante, nos indagamos em que medida o breve esplendor da utopia americanista durante das décadas de 1960 e 1970 contribuiu para o enriquecimento de nossa poesia. Como os poetas que optamos por estudar ampliaram sua expressão com o alargamento da perspectiva nacional e os diálogos então semeados? O que restou daquele ímpeto? Que poemas mantêm em sua tessitura formal as marcas felizes de um encontro com o "outro"? Um "outro" que ultrapasse qualquer exotismo eufórico, qualquer dado arbitrário de irmandade idealizada e que crave em nossa experiência cultural a marca da solidariedade e dos desafios em convivermos, talvez não como irmãos, incapazes que somos de falar a mesma língua, mas como amistosos conhecidos. Neste conhecimento, a poesia - e a reflexão sobre a poesia poderá prestar sua valiosa contribuição com seu manancial de imagens, ritmos e tensões. 


\section{1- As bases de um diálogo}

\section{1- O Brasil dos anos 50: euforia política e drama poético}

Durante o período que caracterizou a chamada Guerra Fria, a América Latina teve, talvez de maneira inédita em sua história, uma destacada importância estratégica no cenário global. Diferentemente do papel secundário exercido nas duas grandes guerras $\underline{\underline{2}}$, o continente assumiu um inesperado protagonismo na geopolítica mundial conforme se tornava cada vez mais tenso o dualismo ideológico determinado pelo conflito de influências entre EUA e URSS. Desse modo, a partir do impacto da Revolução Cubana, em 1959, era alardeada a tese, quase a certeza, de que o conflito entre o modelo capitalista estadunidense e o comunismo soviético seria decidido em terras americanas. Hipótese que animava a militância de esquerda, intensificando a crítica ao status quo e, simultaneamente, gerava duras reações das forças hegemônicas, tanto no âmbito interno - dos grupos políticos dominantes, levando aos famigerados golpes militares, com aval das burguesias locais - como no plano externo - com a costumeira vigília norte-americana em seu "quintal" latino.

O financiamento de focos guerrilheiros em vários países da América Latina, desenvolvidos com treinamento e capital cubano-soviético, ou a "Aliança para o progresso" - programa do governo estadunidense que, com o intuito de aliciamento e pressão econômica, investiu enormes quantias nos países latinos visando frear a ameaça socialista - são, ao lado das ditaduras militares semeadas por Washington, os desdobramentos mais conhecidos deste embate decisivo que se travava em solo americano.

No que diz respeito ao plano da cultura, esse repentino protagonismo teve consequências em todos os níveis imagináveis. Em primeiro lugar, os intelectuais e artistas eram cada vez mais cobrados a tomarem partido (muitas vezes em sentido literal) e atuarem com afinco na vida política

2 Ao comentar o caráter global da Segunda Guerra Mundial, o historiador Eric Hobsbawm salienta a participação secundária da América Latina no conflito, "participando apenas de forma nominal da guerra" (HOSBSBAWM, 2010, p. 30). Para mensurarmos a diferença no papel da América Latina durante o século XX e seus desdobramentos na vida cultural do continente, podemos pensar num exemplo bem simples do nosso repertório poético: em um poema brasileiro típico da Segunda Guerra Mundial, como "Carta a Stalingrado", de Carlos Drummond de Andrade, impera no sujeito lírico uma sensação de afastamento diante dos acontecimento fatídicos, dos combates e lutas sangrentas que se travavam numa longínqua, embora liricamente aproximada pelo ímpeto solidário do sujeito, Europa: "A tamanha distância procuro, indago, cheiro destroços sangrentos" (ANDRADE, 1984, p. 202). Os embates decisivos são desenvolvidos há muitos quilômetros, chegam ao sujeito, perplexo e solidário, apenas como notícias épicas (a poesia que fugiu dos livros e infesta os jornais, nas palavras do próprio poema). É diferente de muitas representações da Guerra Fria, conforme veremos ao longo do trabalho, nas quais os poetas demarcam um espaço enunciativo de proximidade com os grandes embates do período, atuando e sofrendo na escrita da História que se desenrola dramaticamente ao seu redor. Para maiores detalhes sobre a presença da Segunda Guerra na poesia brasileira ver trabalho de Murilo Marcondes Moura (1998). 
nacional, imbuídos de contribuir para os rumos estruturais do país, modificando-o. O debate sobre a função do intelectual já era efusivamente colocado desde os tempos do Estado Novo getulista, nos anos 1930. Escritores como Mário de Andrade, Carlos Drummond de Andrade e vários outros que haviam participado do movimento modernista passaram, marcados pela tentativa de cooptação dos pensadores por parte do governo Vargas, a questionar as pressões vindas de todos os lados e que, em última instância, incitavam os intelectuais a abandonar a reflexão mais criteriosa e autônoma para se envolverem diretamente nas causas pontuais da realidade política (MICELI, 1979). Os efeitos deste tenso embate intelectual referendava caminhos extremos que interpunham os homens de ideias num incômodo espaço entre a liberdade evasiva da "torre de marfim" e a pressão partidária que visava subjugar o ato criador à necessidade urgente de ação política pressentida naquele momento histórico.

Os dilemas vividos pela classe intelectual deste período buscavam sua sustentação teórica mais corrente nas obras de dois autores bastante comentados naquele período: Julien Benda e Antonio Gramsci. O ensaio La Trahison des Clercs (1975) é a obra mais conhecida de Benda e circulou abundantemente no Brasil dos anos 1930 e 1940, sendo muitas vezes discutida na correspondência de Mário de Andrade com seus inúmeros interlocutores. Para Benda, o ofício do intelectual se resume aos grandes temas abstratos e universais que ocuparam a energia dos homens de ideias ao longo da história humana. A Justiça, a Liberdade, a Razão, a Morte, a Religião e outras questões de ordem atemporal e transcendente, seriam, segundo ele, as únicas que mereceriam a inquietude do intelecto. Assim, o desvio de sua atenção para os debates mais rasteiros, sua adesão à causas sociais e políticas, enfim, sua investida oportunista nos jogos cotidianos de poder só poderia resultar em desvio de conduta e traição de sua verdadeira e imprescindível função.

A tese de Benda funda-se no outro extremo do pensamento de Gramsci, para quem a ação política é vista não como desvio, mas como uma extensão lógica inerente à atividade intelectual. $\mathrm{O}$ isolamento do sujeito na abstração escapista dos grandes temas e a apatia frente aos acontecimentos do presente seriam, para o pensador italiano, sintoma da covardia que afastou os intelectuais das decisões mais importantes da sociedade. Além disso, o teórico marxista formula um alargamento da noção de intelectual, não mais identificado como símbolo de distinção, autonomia e honraria elitista, mas ampliado-o a todos os atores sociais, como índice irrecusável de potencial transformador.

Mais recentemente, em suas Representações do Intelectual, Edward Said (2002) revisita estas duas formulações a respeito do estatuto do intelectual e busca, a partir delas, encontrar um intermédio mais razoável entre o espaço solitário da "torre de marfim" e as pressões da "praça de 
convites" comprometimento social e político, mas faz da transcendência propiciada pela "torre de marfim" seu espaço de atuação possível, sendo o distanciamento do proselitismo e das polêmicas cotidianas não uma omissão, mas uma saída estratégica para o cumprimento de sua verdadeira, perene, nobre e possível - função social. Pensando na vida intelectual brasileira, tanto o Drummond pós- $A$ Rosa do Povo como Mário de Andrade, embora censurassem as facetas mais evanescentes e escapistas do pensamento de Benda, viram na liberdade de reflexão por ele proposta - que não nega a práxis mas que tenta processar-se fora dela - a única saída diante da crescente cobrança dos órgãos da esquerda para que todos os simpatizantes do ideário comunista convertessem suas produções artísticas em teses doutrinárias, panfletos colhidos dos estreitos receituários jdanovistas para serem digeridos pelas massas trabalhadoras.

Já em meados da década de 40 este caudaloso debate - que, como sugere Said, assenta-se numa duvidosa incompatibilidade entre ação política e reflexão crítica - parecia estar, ao menos na poesia brasileira, em vias de superação. A divisão do trabalho intelectual, acelerada nos anos 40 e muito bem estudada por Iumna Simon (1993), retirou dos escritores a tradicional cobrança resultante do monopólio que a matéria literária possuía enquanto canal privilegiado de análise e reflexão sobre os problemas e as identidades nacionais. Até então, na tradição literária brasileira o escritor era, antes mesmo de um artista, um intérprete do Brasil, uma espécie de duplo do sociólogo, alguém que formulava certo conhecimento sobre o país. Conforme as ciências sociais desenvolviam-se nas universidades e o aparato teórico do new criticism ganhava adeptos em nossos meios críticos, os escritores, mormente os poetas, ganhavam margem para ampliar o estudo formal, para o aprimoramento da técnica literária e para uma maior liberdade criativa, "traduzindo a necessidade de se constituir um território próprio e autônomo para a expressão poética" (SIMON, 1993, p. 343). A função principal da literatura, ao menos da dita "literatura de permanência", deixava de ser o estudo e a formulação de conhecimentos sobre a sociedade brasileira e passava a encontrar na própria matéria linguística, na experimentação e no trabalho formal, sua preocupação primeira.

Como resultado deste processo de apuração da linguagem, tivemos nos anos 1940 um retorno quase que generalizado às formas fixas; enxurradas de sonetos se proliferavam em revistas e suplementos literários, rimas meticulosamente requintadas tornavam-se quase regra e um gosto pela mitologia clássica emergia com força em nosso cenário poético. Este retorno ao ritmo tradicional pode ser sentido tanto na sempre criticada "geração de 45 ", frequentemente marcada por um

3 "Na praça de convites" é o título que Carlos Drummond de Andrade (1996) escolhe para o capítulo de sua antologia poética que engloba os poemas mais identificados com a participação solidária. 
marcelo2867@gmail.com

esteticismo meio pedante, como por parte de nossos poetas mais importantes: Drummond, Vinícius de Moraes, Murilo Mendes, Jorge de Lima, Cecília Meireles, Manuel Bandeira, todos, àquela altura, dialogando em algum grau com a tradição clássica e as formas fixas. O êxtase causado pela libertação dos compromissos de interpretação do país lançaram vários de nossos autores ao outro extremo: a geração formada por nomes como Lêdo Ivo, ficaria marcada pelo meticuloso trabalho verbal e pela pouca substância crítica, a pouca inovação dos recursos expressivos, despertando em boa parte da crítica a convicção de que havia "abusos de pesquisas formais e queda na qualidade média da produção" (CANDIDO, 1985, p. 137).

Críticas como a de Antonio Candido multiplicaram-se rapidamente, de modo que já em meados da década de 1950 esta concepção de poesia sofisticada, obediente à padrões aristocráticos de bom gosto, já se encontrava em crise. De um lado, os movimentos de pretensão vanguardista retornavam com grande energia, primeiro com o concretismo paulistano e depois com o neoconcretismo carioca, ambos exigindo um tratamento mais radical e inovador da linguagem poética. Por outro lado, o período de relativa estabilidade democrática fortaleceu o desejo de reformas sociais e culminou com a consolidação da hegemonia das esquerdas no cenário cultural brasileiro, algo que vinha sendo esboçado desde a década de 1930, com o primeiro grande ciclo de crescimento do PCB. Uma nova proposta de articulação profunda entre arte e sociedade passou a reunir e congregar, no início da década de 1960, um grande número de intelectuais interessados num projeto de "conscientização das massas populares" visando transformações sociais profundas. Assim, o retorno às formas tradicionais era outra vez ressignificado como atitude regressiva, decadente, pois para a nova intelectualidade engajada "a relação direta estabelecida entre arte e sociedade era tomada como palavra de ordem e definia uma concepção de arte como serviço e superinvestida do ponto de vista de sua eficácia imediata” (HOLLANDA, 2004, p. 19).

Anulava-se os resquícios do discurso de Benda e suas releituras por parte de nossos modernistas - que afirmavam que o comprometimento do intelectual não deveria se envolver paternalmente com a realidade imediata e sim garantir o distanciamento mínimo para proferir um juízo o mais imparcial possível - e alardeava-se, como única opção válida, seu mergulho compulsório no "tempo presente".

É neste complexo cenário político e cultural que Ferreira Gullar e Thiago de Mello começam a publicar seus primeiros livros. Gullar edita A Luta Corporal em 1954, livro de impacto instantâneo, que se inicia com "Os Sete poemas portugueses", marcados por um tom comedido, vocabulário denso e grave, nuances simbolistas e métrica fixa, bem ao gosto da "geração de 45", e se encerra na mais voraz pulverização da linguagem em "Roçzeiral", experiência limite que abria 
espaço para as vanguardas em gestação. Depois deste livro de estreia ${ }^{4}$, flertará com o concretismo, mas logo romperia com as ideias do grupo paulistano e iria se tornar um dos mentores do neoconcretismo carioca. Sua participação nas vanguardas só é encerrada quando se aproxima dos CPCs e do engajamento mais aberto publicando, no início dos anos 60, os Romances de Cordel e depois, ao lado de figuras como Oduvaldo Viana Filho, o Vianinha, criaria algumas das mais importantes peças políticas do teatro Opinião, dentre as quais vale destacar Se Correr o bicho pega, se ficar o bicho come (1966) e A saída? Onde fica a saída? (1967). É essa inquietação constante e a posição destacada que ocupou em praticamente todos os principais movimentos que agitaram a arte brasileira na segunda metade do século XX que fez com que João Luís Lafetá o definisse como um verdadeiro "repórter do nosso tempo" (LAFETÁ, 2007a, p. 242).

Seu vibrante pensamento seria, com a mesma relevância, combustível teórico para o debate vanguardista e para o front cultural do partido comunista, merecendo destaque suas ideias a respeito da arte nacional que ficariam demarcadas no livro Cultura Posta em Questão (1966) e, mais tarde, em Vanguarda e Subdesenvolvimento (1974). Destes esforços teóricos reproduzimos um excerto que ilustra seu pensamento naquele momento de total entrega à causa revolucionária:

Quanto a mim, estou convencido de que o fenômeno presente da poesia, não apenas responde a causas sociais profundas, como encontra condições, dentro do próprio processo da poesia brasileira, para nele se inserir, ampliando-o e enriquecendo-o. Noutras palavras: sem recuar um passo do propósito político que os anima, mas antes firmando-se nele profundamente, podem os poetas, não apenas contribuir na luta de transformação social do país, como abrir perspectivas novas para a criação poética (GULLAR, 1974, p. 16).

Thiago de Mello, por sua vez, publicou seu primeiro livro em 1951. Sua poesia também nasce com vários ecos do formalismo cultivado pela geração que o antecedeu e que, é bom lembrar, continuava publicando naquele período ${ }^{5}$. Diferentemente de Gullar, seu caminho terá menos curvas e bifurcações nas variações formais que experimentará ao longo da carreira. Passará às margens do experimentalismo vanguardista, mas aceitará a urgência da cobrança política que, a partir de 1960, será matéria invariavelmente presente em seus escritos. Os primeiros livros do poeta deixam de lado o engajamento explícito e apenas tangenciam, ocasionalmente, uma vaga crítica social e uma cintilação a-histórica de utopia. É só a partir de Faz escuro mas eu canto (1966) que intensificará a matéria política de seus escritos. O comprometimento para com os mais humildes se torna um

4 A bem da verdade, Ferreira Gullar já havia publicado, em 1950, um outro livro de poemas, Um Pouco Acima do Chão, que ele logo renegaria, deixando assim de constar em suas poesias completas.

5 Para Alceu Amoroso Lima, Thiago de Mello "é um dos mais típicos representantes da chamada 'geração de 45"” (LIMA, 1966 apud MELLO, 1984, p. 151). Opinião que não compartilhamos, conforme se verá um pouco mais adiante. 
marcelo2867@gmail.com

obsessivo compromisso durante os anos de exílio e nunca mais abandonaria o tom solidário e didático de seus versos.

Por hora, nos afastemos outra vez dos escritores para analisarmos um outro aspecto do contexto histórico em que iniciam a publicação das obras que mais nos interessam para a presente reflexão, isto é, os textos marcados pelo rótulo do engajamento que escreveram a partir da década de 1960.

\section{2- As máscaras e os espelhos: o escopo da latinidad na militância poética}

Quando comentamos a importância que a América Latina assume no cenário geopolítico durante a Guerra Fria estávamos também lidando com um dos fatores que potencializaram o esforço comunitário levado a cabo nas obras poéticas daquele período. A generalizada sensação de que o futuro do mundo, seus rumos e sonhos, estava sendo decidido em solo americano alimentou a aproximação - ou melhor seria dizer o desejo de aproximação - entre atores sociais dos países latino-americanos. Propagava-se a crença de que a América poderia, enfim, oferecer sua contribuição civilizatória à humanidade, o que alimentava principalmente na juventude e nos intelectuais um entusiasmado desejo de participação coletiva, de fazer a História, de superar as feridas do subdesenvolvimento e criar novas formas de socialização, mais humanas e justas.

Assumia-se, como síntese da vocação à integração continental, o não superado passado de dominação e interferência estrangeira - primeiro com o colonialismo ibérico e depois com o imperialismo norte-americano. O senso crítico desta nova geração expandia ao grau extremo aquilo que Antonio Candido chamou de "consciência crítica do subdesenvolvimento" (1973). De acordo com o crítico paulista, até o século XIX imperava entre os intelectuais americanos uma "consciência amena do atraso". Ela era baseada na crença de que os países latinos, pela sua exuberância natural e juventude de espírito, estavam destinados ao inexorável caminho do progresso. Já nas primeiras décadas do século XX, tal confiança era em larga medida substituída por uma abordagem mais crítica e negativa, baseada na constatação de que os países latinos não lograram os avanços antes sonhados na época das independências, muito pelo contrário, as contradições internas e a dependência estrangeira se atualizavam com os mesmos efeitos nocivos do período colonial. Por fim, se formulava a tese de que nenhuma conquista social poderia ser alcançada de maneira espontânea, harmônica, ou seja, fora do âmbito da luta e sem as urgentes e profundas transformações na sociedade.

A gradual passagem de uma explicação mítica e natural da condição latino-americana para 
uma leitura problematizadora desta realidade - examinada, a partir do âmbito literário, por Antonio Candido, mas presente também nas ponderações de um Angel Rama (2008) ou de um Eduardo Galeano (1990), por exemplo - estava em consonância com o desejo de diálogo semeado por atores sociais dos países latinos e na ordenação de uma identidade que justificasse tal união. $O$ reconhecimento dos aspectos sociais, históricos e políticos comuns entre os países latinoamericanos passa a anteceder a celebração de convergências culturais, bem menos evidentes, dada a diversidade característica do continente ${ }^{6}$. O discurso identitário do período será formulado, pois, inicialmente no plano político, muitas vezes lido em chave idealizada e utópica, e dele decorrerá reconhecimentos de outras ordens, que apontam para as mesmas saídas históricas.

Seria exaustivo expor aqui, ainda que de modo sumário, todas as passagens históricas que contribuíram para a formação das nações latino-americanas e para a construção ideológica dos laços (bem como a fragilidade deles) entre o Brasil e os países vizinhos. A assinatura do Tratado de Tordesilhas seria um início óbvio para quem deseja acompanhar o desenrolar histórico destas relações. A partilha das novas terras impunha, desde a gênese do processo colonizador, uma linha virtual que separava as terras daquilo que viria a ser o Brasil, de colonização portuguesa, dos demais territórios, subjugados à metrópole espanhola. Este estudo passaria necessariamente também pelos processos de independência: o Brasil sem apresentar uma luta violenta, nas proporções dos vizinhos, que de várias maneiras se uniram contra o colonizador; sua independência tardia e limitada, colocando-o à sombra das lutas libertárias que construíram heróis emblemáticos como um Simon Bolívar ou um San Martín, mártires que deixavam projetos visando à constituição de uma única e grande nação (hispano) americana.

Partindo de uma espécie de psicanálise do imaginário social, o filósofo português Eduardo Lourenço, afirma que, devido a falta de um pai digno de ser morto, os brasileiros "puseram entre parênteses as suas raízes lusitanas, como recusa da relação obcecante de uma origem vinda de outro lugar" (LOURENÇO, 1999, p. 157). Se a arrastada independência brasileira afastou, como bem defende Lourenço, a busca de uma ancestralidade portuguesa, podemos completar dizendo que também resultou em desvios históricos, sociais e culturais entre a formação do estado nacional brasileiro e a consolidação das emergentes nações hispano-americanas. Basta observar as diferenças entre o romantismo nos países hispânicos - com seu resgate das lutas sangrentas e gloriosas pela independência, culminando na elevação mítica de uma elite criolla - e do brasileiro - que elegeu a

6 Eneida Maria de Souza, em diálogo com os estudos americanistas mais recentes, reconhece a configuração de um cenário em que países geográfica e socialmente próximos, mas culturalmente afastados, buscam a ordenação desmistificada de uma identidade conjunta, bem como a construção de uma história latino-americana. (SOUZA, 2007, p. 149). 
matéria indígena como traço maior da identidade nacional, substituindo o tom triunfalista da vitória diante do dominador pelo da conciliação sintética entre os grupos que formaram a imagem megalomaníaca de um país que supostamente "já nasceu avisado que seria independente" (LOURENÇO, 1999, p. 173).

Por isso, quando se começava a formular uma identidade latino-americana, os principais teóricos perguntavam-se com frequência o lugar (ou não-lugar) do Brasil naquela fulguração.

O termo América Latina só ganharia força no final do século XIX e surgia como resposta local ao então corrente uso da noção de panamericanismo, que abarcaria os países do continente lado a lado com a crescente potência norte-americana ${ }^{7}$. Como defesa de uma união em torno da condição econômica e cultural (inclusive linguística) dos países, o termo América Latina inicialmente exclui tanto os EUA como o Brasil de seu horizonte transformador:

a nova safra de pensadores latino-americanos batizados como a Geração de 900 zelou pela promoção de um movimento continental "espiritual" em defesa dos valores da "hispanidad" e da "identidade nacional" frente aos perigos que a influência da política norte-americana poderia potenciar (LOGUERCIO, 2007, p. 141).

Vem destes laços conturbados a força das palavras de Lourenço. A imagem que o filósofo lusitano esboça do Brasil como "país do disfarce" ilumina este tenso jogo de pertencimento: sem ter conquistado violentamente sua independência, restou acreditar que ela já estava dada naturalmente, mesmo antes dos portugueses aqui chegarem, distanciando-se, assim, tanto do "pai ausente" português, como dos países vizinhos que, por precisarem se organizar visando a imposição violenta e continentalmente articulada do projeto nacional, não puderam forjar a mesma falsa ideia de “autonomia espontânea” que os brasileiros inventaram para si. (LOURENÇO, 1999, p. 172-179)

Já separados pela força destes desencontros, e de tantos outros que não nos cabe aqui examinar a fundo, o Brasil entra no século XX. Os caminhos abertos pela modernidade convivem com as tradições e o conservadorismo herdados da sociedade patriarcal e escravista que movia a máquina colonial, dando o tom de uma convivência oportunista entre o moderno e o passadiço que seria, na ótica de sociólogos como Florestan Fernandes, um diferencial da modernização na América

7 A questão é aparentemente datada; mas só aparentemente. Esta mesma discussão tem ressonâncias no debate político contemporâneo por meio do impasse entre uma Área de Livre Comércio das Américas (a moribunda ALCA, encabeçada pelos EUA) e os projetos mais voltados para a construção de grupos paritários e horizontais, como pretende ser o MERCOSUL e a UNASUL. Malgrado a ênfase econômico/comercial destes grupos, explicada pelas imposições do Consenso de Washington, pode-se perceber o modo como as questões de interesse dos países ainda se mistura à busca da ordenação de um projeto identitário continental. A posição do Brasil nesta projeção, sempre controversa, vai oscilando: ora é visto como uma peça chave da integração latino-americana, ora como um gigante imperialista adormecido (hoje, já começando a despertar) a ser tratado com precaução dentro dos grupos supranacionais. 
Latina ${ }^{8}$. A afinidade entre os projetos modernistas, todos eles voltados para uma renovação estética radical, não foram, porém, suficientes para uma aproximação mais fértil neste período de intensa renovação artística. As vanguardas latino-americanas, que correspondem ao nosso movimento modernista, processavam na década de 1920 uma ampla circulação de manifestos, poemas e movimentos dentro do continente, a tal ponto que figuras como Vicente Huidobro, Pedro Mariátegui e Cesar Vallejo, além de conviverem juntos nas longas estadas em Paris, tinham trânsito livre na América de fala hispânica e, mais a frente, nos anos 1930, até mesmo alavancaram um olhar crítico sobre a antiga metrópole espanhola ${ }^{9}$, num processo de redescoberta da Espanha e restabelecimento crítico de laços culturais.

Enquanto isso, no Brasil o modernismo mostrou-se programaticamente endógeno. Justa exceção feita ao conceito de antropofagia, retomado anos mais tarde por grande parcela da crítica americanista e até hoje matéria indispensável para se pensar a cultura latino-americana ${ }^{10}$, as demais contribuições da reflexão modernista ficaram opcionalmente concentradas no entendimento do país, da sua cultura e diversidade regional. Frente ao intercâmbio e circulação de ideias e propostas nas vanguardas hispano-americanas, o debate sobre a América Latina em nosso meio intelectual ficou restrito à revistas de breve circulação, como a Terra de Sol, dirigidas por autores secundários, sem o prestígio dos nomes graúdos do modernismo brasileiro que seriam rapidamente absorvidos pelo cânone nacional ${ }^{11}$. A ênfase dos escritos de Mário de Andrade, por exemplo, recaía sempre numa aproximação crítica da cultura nacional, sobretudo da popular, com o intuito de fecundá-la com o olhar erudito da renovação estética, o que explica, em partes, seu relativo desinteresse em relação à América Latina e sua engajada recusa à matriz portuguesa ${ }^{12}$.

8 O termo "modernização conservadora" é adotado por Florestan Fernandes (1974) para explicar as particularidades e contradições da modernização brasileira. Os desdobramentos do conceito têm gerado uma sólida tradição dentro crítica sociológica brasileira.

9 Trata-se de um retorno estratégico ao diálogo com a antiga metrópole. No final da década de 20, os literatos hispano-americanos ensaiam uma aproximação com a ex-metrópole gerando fecunda circulação de repertórios. Ver ZANETTI (1993).

10 Ver por exemplo as reflexões propostas por Eduardo Subirats (2001), ao relacionar o conceito de antropofagia, desenvolvido por Oswald de Andrade, com os desafios culturais enfrentados pela América Latina.

11 Em sua tese de doutoramento, Raquel dos Santos Souza (2008) estuda algumas das principais revistas literárias do período. A autora observa que a vertente americanista foi bem menor que a vertente lusitana, sendo, no entanto, esboçada na revista América Latina, que daria origem à Terra de Sol. Não obstante, ela conclui que o desejo de circulação de repertórios nunca se concretizou de fato e o foco americanista se diluia gradativamente de modo que nos números derradeiros, fora a contribuição de um ou outro colaborador estrangeiro, tínhamos todas as características de uma revista brasileira típica, nos moldes das demais publicações modernistas.

12 Tal recusa aparece de maneira confessa em vários trechos de seus textos programáticos e de sua vasta correspondência. Em carta a Manuel Bandeira, o poeta paulista escancara, como parte de seu programa literário e cultural, a aceitação de uma "língua brasileira", livre das ressonâncias portuguesas. Com um desdém que ilustraria 
A matriz estética, tanto hispânica como brasileira, era francesa; dizia-se até que, nas primeiras décadas do século, a capital artística da América Latina era Paris. No entanto, enquanto os autores argentinos, chilenos, peruanos, colombianos, participavam de debates comuns, liam com animado interesse os manifestos uns dos outros e realizavam conferências conjuntas entre os países, no Brasil muito pouco se conhecia dos movimentos que se deflagravam na América Latina ou em Portugal, a não ser uma ou outra informação que aqui chegava por meio de notícias trazidas por intelectuais estrangeiros que para cá se transferiam.

Um dos raros nomes fortes deste diálogo travado entre Brasil e América Hispânica nos anos 1030 foi Alfonso Reyes, humanista e escritor mexicano, embaixador do México no Brasil entre 1930 e 1937. Em pesquisa sobre o intelectual mexicano, Cecília Laura Alonso discute o trabalho de Reyes durante o tempo que passou no Rio de Janeiro. Sua atuação visava abrir algum espaço para se formular um pensamento latino-americano e, com esta ideia, publica Monterrey: correo literário de Alfonso Reyes: "ponto de contato entre Reyes e seus amigos intelectuais, onde o intercâmbio cultural era constante e se punha em questão pontos de vista sobre o Brasil, México e América Latina" (ALONSO, 2006, p. 28).

Apenas em meados da década de 1950 esta tendência começa a ser temporariamente revertida. Pelas razões já apresentadas, e outras que trataremos de discutir no decorrer da análise, o olhar de boa parte da nossa intelectualidade volta-se para a América Latina, convertida em um privilegiado horizonte de união política e transformação social. A aparente soberba antes dominante entre a intelectualidade brasileira passa a ser contrastada por um forte sentimento de pertença e um consciente desejo de solidariedade. As diferenças que marcaram o caminho singular do Brasil, ilhando-o dentro da América de fala hispânica, tornavam-se, no discurso da época, menores que as inequívocas convergências: a condição de exploração, a luta contra o imperialismo, a mestiçagem, a injusta distribuição de terra e renda, iam tilintando como palavras-chave que alimentavam um sentimento de comunitarismo que a literatura de teor participativo logo trata de tomar como sua bandeira.

A hesitação dos pensadores do século XIX, duvidosos em inserir o Brasil no grande projeto latino-americano, dá lugar a discursos identitários que em momento algum questionam a presença brasileira num projeto de América. Os exemplos são sólidos e contundentes: na poesia, com o Canto General (1951) de Pablo Neruda, espécie de enciclopédia lírica do continente; nos estudos teóricos do período, como em As veias abertas da América Latina (1971) de Eduardo Galeano, até chegar ao 
discurso político de um Che Guevara, o Brasil sempre estava inserido naquela noção de América, compartilhando tanto as dificuldades impostas pela dependência, como os "sonhos diurnos" (BLOCH, 2005) que convidavam ao combate.

Poetas latino-americanos antes negligenciados e de circulação restrita no Brasil começavam a ser traduzidos no país. A poesia completa de Cesar Vallejo é traduzida pelo próprio Thiago de Mello; os chilenos Vicente Huidobro e Nicanor Parra também ganham edições em português. A Revista Civilização Brasileira chega a ser lançada simultaneamente em vários países latinoamericanos, superando a tiragem de 45 mil exemplares num mesmo número, contando com colaborações de vários escritores do continente (AZEVEDO, 1999). Neruda é recebido na Academia Brasileira de Letras, Che Guevara é condecorado por Jânio Quadros, vários eventos pareciam mostrar que a inserção do Brasil na América Latina poderia deixar de ser mero acaso geográfico para se tornar, nos sonhos de uma geração, um ensaio de solidariedade e atuação conjunta.

\section{3- Do drama linguístico ao engajamento poético: notas sobre duas poéticas que se cruzam}

É na véspera deste embate traçado na campo literário brasileiro que Thiago de Mello e Ferreira Gullar publicam suas primeiras obras, ainda na década de 1950. Data de 1951 o lançamento de Silêncio e Palavra, primeiro livro de poemas de Thiago de Mello, e de 1950, ainda em São Luís do Maranhão, de Acima do Chão, estreia de Gullar em livro, muito embora o autor renegue tal publicação e considere A Luta Corporal (1954) como marco inicial de sua trajetória literária.

O contexto social, como já sublinhamos mais atrás, apresentava uma ampla série de tendências em embate dentro da poesia brasileira. O ímpeto modernista havia perdido o fôlego de outros tempos; a rotinização de suas inovações ia esvaziando o caráter de ruptura que lhe dava sentido. Além disso, a essa altura, boa parte dos modernistas mais ilustres, seja os da chamada primeira ou segunda geração, já ocupavam confortáveis poltronas dentro do cânone brasileiro, inclusive dentro de instituições como a Academia Brasileira de Letras. Este esgotamento da proposta vanguardista gerou uma rápida passagem da contestação quase iconoclasta do modernismo heroico, para uma condição de modelo mais prestigiado.

Como consequência deste "envelhecimento do moderno" $\underline{13}$, processava-se em nossas letras

13 O termo é inicialmente utilizado por Adorno e analisado por Peter Burguer (1988, p. 81-95). De acordo com o crítico, a rápida diluição da proposta modernista é sentida em toda a arte ocidental. O retorno às formas clássicas, o culto à tradição e a generalizada perda da energia contestatória das vanguardas artísticas seriam alguns dos principais indícios deste processo. 
um sintomático abandono do experimentalismo coloquial em nome de um regresso às formas fixas, à mitologia e à estruturação poética tradicional. A chamada "geração de 45" acabaria, até os dias atuais - visto que boa parcela da nossa alta crítica ainda é visceralmente modernista - estigmatizada por esta postura taxada de regressiva, evasiva e esteticista, já que seus membros elaboravam um retorno mais ou menos passivo à ideia de "poesia pura", no que ela teria de mais conservador. Vale destacar, contudo, que se fora, anos mais tarde, renegada pelo cânone literário por conta de seu hermetismo opaco, purismo e gosto pelas divagações evanescentes, a dita "geração de 45" travava com seus contemporâneos um faiscante debate, no qual tanto Thiago de Mello como Ferreira Gullar eram atores de primeira linha. Como explica Vagner Camilo, em ensaio que estuda a posição de Carlos Drummond de Andrade nesta guinada classicizante da poesia brasileira, o debate a respeito dos rumos da poesia naquele período histórico era de alcance abrangente:

(...)nesse contexto marcado pela especialização do trabalho artístico, as tendências formalistas e classicizantes da poesia vieram acompanhadas de um intenso e acalorado debate de ideias não só entre os poetas, mas também entre os críticos do período que, à discussão sobre a natureza do 'essencialmente estético', o hermetismo, a poesia pura, as formulações teóricas e o legado poético de Eliot, Valery e seguidores, aliavam a disseminação dos postulados do new cristicism, então em voga. (CAMILO, 2001, p. 56)

Parece infecundo nos aproximarmos dos dois poetas estudados sem ter em mente a clara dimensão do impasse que está no cerne de suas obras: valeria a pena, naquele momento de intensa pressão social, render-se ao virtuosismo poético de um "neo-parnasianismo", ressaltando o artesanato da linguagem, a perícia metafísica do artista? Ou melhor seria atender ao ruidoso chamado do tempo presente e entregar-se à participação política, convertendo, assim, a poesia em instrumento pedagógico-propagandístico, sacrificando o trabalho formal mais denso para atender à comunicação direta com a instância tão longínqua e reticente chamada vagamente de "povo"?

Acreditamos ser este o impasse inicial das duas poéticas em questão, ao menos em seus primeiros livros, às vezes encenado dialeticamente no interior de seus motivos, gerando resultados interessantíssimos do ponto de vista da riqueza expressiva, mas outras vezes sem atingir síntese alguma, sendo, nestas situações, apenas um eufórico entregar-se a cada uma dessas perspectivas. Para encerrarmos momentaneamente a discussão sobre as tendências poéticas dos anos 1950, podemos destacar também que é no decorrer deste embate entre duas posturas literárias distintas - e mais uma terceira via, de atualização vanguardista, não menos importante, cujo expoente máximo é o movimento concretista - que a solidariedade latino-americana encontrará ecos em nossa poesia e se tornará, como defendemos neste trabalho, matéria relevante na produção artística daquele momento. 
Esboçado este painel geral, podemos aprofundar nosso olhar na direção das primeiras obras dos autores estudados. O estudo destes livros iniciais não toca exatamente na questão de um diálogo latino-americano, o que explica a opção de não levarmos a cabo uma leitura exaustiva dos seus poemas, guardando fôlego para a análise dos livros em que a matéria americanista é mais abundante e acabada. Não obstante, a compreensão dos condicionamentos sociais e dos percursos individuais que levam os poetas a se irmanarem num projeto cultural mais amplo exige a elaboração de um cuidadoso panorama dos temas e formas contidos nestes primeiros livros. Da mesma maneira que se faz imprescindível um mapeamento da posição que estes autores ocupavam na constelação da poesia brasileira naquele momento específico e como este espaço se desloca no decorrer de suas trajetórias.

Comecemos por Thiago de Mello. Menos conhecido - e reconhecido - que Ferreira Gullar, Thiago de Mello nasce em Barreirinha, pequena cidade do Amazonas ${ }^{14}$. Chega ao Rio de Janeiro em 1948, onde inicia o curso de medicina, que logo abandona para dedicar-se exclusivamente à poesia. Seu livro de estreia, Silêncio e Palavra (1951) recebe uma acolhida bastante favorável que logo coloca o escritor amazonense como um dos poetas da nova geração com maior prestígio entre a crítica especializada. A respeito do entusiasmo com o qual é recebido pela alta intelectualidade carioca como virtuoso poeta, podemos citar a admiração de Manuel Bandeira diante dos seus versos $\underline{15}$ e a longa resenha que Álvaro Lins - então um dos críticos mais respeitados do jornalismo brasileiro - tece sobre a primeira obra do poeta. Nela ele diz:

Poetas principais de nossa literatura: estou tentado a pedir-vos um lugar, ao vosso lado, para o poeta de Silêncio e Palavra. Com vinte e seis anos, e um só livro publicado, o Sr. Thiago de Mello bem demonstra, todavia, que já se acha em condições de situar-se na primeira linha da nossa poesia contemporânea (LINS, 1952 apud MELLO, 1984, p. 25)

Após Silêncio e Palavra, o poeta manterá uma publicação regular de livros de poemas até 1960, momento no qual se aproxima de vez do debate político que transformará sua expressão literária, muito embora o primeiro resultado poético dessa nova faceta de sua poesia só venha a público em 1966, com o livro Faz escuro mas eu canto, quando já era adido cultural do Brasil no Chile. Demarcamos, assim, o que poderia ser visto como uma primeira fase da poesia de Thiago de

14 Assim como em Gullar, a cidade natal será frequentemente tematizada pelo poeta e será um dos alvos do nosso estudo no último capítulo do trabalho, quando analisaremos as obras mais recentes, publicadas num contexto de refluxo político e distopia.

15 No prefácio da primeira de edição de Vento Geral - obra que reúne a produção poética de Thiago de Mello, Manuel Bandeira afirma: "É grande poeta, um dos grandes de sua geração e de qualquer geração". (BANDEIRA, 1960 apud MELLO, 1984, p. 163) 
Mello; ela abarca os livros Silêncio e Palavra (1951), Narciso Cego (1952), Romance do primogênito (1952), O Andarilho e a manhã (1953), Tenebrosa Acqua (1954) e Toadas de Cambaio (1959), sendo que o livro seguinte, Ponderações que faz o defunto aos que lhe fazem o velório (1960), já começa a se distanciar das característica iniciais.

Trata-se, neste momento de busca por um timbre próprio, de livros fortemente marcados pela estética da "geração de 45", que apresentava nomes como Lêdo Ivo, Alphonsus de Guimaraens Filho, Mauro Mota, Domingos Carvalho da Silva, dentre outros. Praticamente todos os poemas desta fase apresentam um sistema fixo de metro, embora, no caso singular de Thiago de Mello, pouquíssimos tenham rimas regulares. Trata-se, sem dúvida, de uma marca pessoal do autor, identificada por Manuel Bandeira (apud MELLO, 1984, p. 112) como uma estratégia para escapar dos cacoetes formais da época. Apesar desta tímida ruptura com o formalismo, seus primeiros poemas apresentam um vocabulário solene, cadências caprichosas, sem nenhuma referência ao coloquialismo modernista. Os temas são graves e abstratos, não raro intensamente metafísicos; poucas vezes (talvez em dois ou três poemas e de maneira dispersa, rarefeita) trazem em seu horizonte o mundo histórico e uma vaga insinuação sobre problemas sociais.

É oportuno, a título de ilustração, comentarmos um poema exemplar presente em seu livro primeiro:

\section{O muro invisível}

É inútil minhas palavras ultrapassarem fronteiras se eu ainda permaneço.

Muro invisível existe entre o dizer e o fazer e, talvez, à sua sombra, apenas envelheçamos.

Jamais saberá a relva quando o orvalho descerá, e é dádiva da terra o que amadurece os frutos.

Sou qual a ávida planície esperando vir dos céus a chuva fertilizante. Entremente, vejo flores, sem saber se colherei. 
Em termos formais, o poema marca bem uma adequação aos preceitos estéticos de refinamento do verso: em primeiro lugar, apresenta uma métrica fixa em redondilha maior sobre as quais vale uma constatação já alertada por Álvaro Lins: "Mello apanha em suas mãos a redondilha maior, o metro por excelência da poesia popular, a fim de aristocratizá-lo, de utilizar-se dele com requintes e refinamentos estruturais de expressão artística." (LINS, 1952 apud MELLO, 1984, p. 20).

A "aristocratização da redondilha", na voz conservadora de Álvaro Lins, assume um tom de elogio. E, por sinal, é fácil aceitar que tenha sido um elogio bem aceito pelo poeta, visto o padrão de pureza e limpidez formal que sua poesia almejava alcançar, enquanto manifestação de uma beleza sensitiva e intelectualizada. Anos mais tarde, quando se consolida como um autor comprometido, o sentido desta "aristocratização" ganhará, certamente, uma acepção pejorativa, alienante e, portanto, contraditória aos objetivos de suas obras "maduras"

No poema em questão, o mencionado requinte das redondilhas consiste em sua utilização para tratar de um tema grave - desordenação dos ciclos naturais como meio de representar a cisão entre o sujeito e a linguagem - e na roupagem com a qual elas revestem o poema com uma dicção reflexiva, de porte notadamente erudito. Vale observar o constante emprego de vocabulário e símbolos próprios da tradição lírica ("sombra", "relva", "flores”), a frequência de vocábulos poucos usuais, rebuscados ou que não correspondem a uma paisagem nacional, como aquelas do gosto modernista, ("Entrementes", “dádiva", "planície”) e, por fim, de uma sintaxe sofisticada, alheia ao emprego popular, sobretudo no que se refere às requintadas inversões ("Jamais saberá a relva", "Muro invisível existe", dentre outras).

A linguagem é tematizada e empregada no poema mais como um obstáculo do que como uma ferramenta para a comunicação. As palavras são inúteis, surgem como uma falsa extensão do sujeito, fadado a tão somente permanecer, suspenso nos muros do silêncio sem superar os espaços que seu discurso é capaz de ultrapassar. Há no tom do poema e em suas imagens indícios de um incômodo frente a autonomia da linguagem, prefigurando uma ruptura que é própria da modernidade e remete a nomes importantes como Valery e Eliot. Chega-se a levantar, bem ao gosto

16 Deixaremos entre parênteses, ao menos por enquanto, o juízo valorativo contido na ideia de maturidade. É muito comum encontrar vários leitores da poesia de Thiago de Mello afirmando que seus primeiros livros são muito superiores às obras pós guinada participativa. Dizem estes que, acometida por um romantismo capenga e voluntarioso, o poeta perde a densidade e o rigor que semeava nos primeiros livros. Por isso, ao falarmos de obras "maduras" nos referimos às que foram escritas a partir de meados dos anos 1960, quando o poeta já ocupava posição destacada diante de um considerável número de leitores, sem pressupor de antemão que estas, por serem escritas depois, possuem uma maior qualidade em relação às anteriores. 
da lírica moderna ${ }^{17}$, o alcance real das palavras e sua ineficácia comunicativa, a dolorosa cisão entre sujeito e linguagem: "É inútil minhas palavras/ ultrapassarem fronteiras/ se eu permaneço". Também merece destaque a utilização de elementos da natureza no símile central do poema: "sou qual a ávida planície”, capaz de fundir o homem e a terra num contínuo de desejo, dúvida e imobilidade. O indivíduo, enquanto natureza estática, permanece melancolicamente preso, fincado no chão, vendo as palavras alçarem voos dos quais ele não participa.

O sóbrio jogo de palavras revestidas de camadas condensadas de significados marca a experiência autônoma da leitura: leitura que é acima de tudo contemplativa, como apontava outro de seus críticos contemporâneos, também simpático ao "verso por excelência" praticado pela "geração de 45":

Ela [a poesia de Thiago] exprime-se na linguagem por excelência do verso, dando a ilusão de uma experiência intelectual que fosse independente de nós mesmos, que pertencesse tão-somente às palavras, existissem dentro delas. Como se as palavras, elas mesmas, pensassem. (MONTENEGRO, 1984, p. 107).

É esta a tônica dos primeiros livros. Não há ali nenhuma alusão aos países latino-americanos ou a qualquer visão de solidariedade, luta política, exploração social, léxico básico dos livros posteriores. Pelo contrário, as temáticas giram em torno dos grandes temas: o amor, a busca da verdade, a própria poesia e a morte. Em poucos poemas a matéria externa aflora, como é o caso de "Poema de Natal" e "Romance de Salatiel" (um dos poemas mais interessantes do primeiro livro, senão de toda a trajetória do autor). Nota-se, entretanto, que quando resolve falar dos homens em sua concretude social, o autor opta por poemas narrativos, descrevendo uma realidade que é construída a partir da observação o mais imparcial possível da cena.

Em “Poema de Natal” (MELLO, 1984, p. 65), por exemplo, há uma situação de miséria, descrita com tom realista, mas sem que o eu-lírico estabeleça uma cumplicidade afetiva com o personagem que advém das classes mais pobres. A descoberta da miséria não se configura, como se dará mais tarde, a partir do impacto subjetivo decorrente da interpretação lírica do mundo social: revolta, desejo de participação e solidariedade, seja com os homens que lhe rodeiam ou, num projeto mais amplo, com todos os explorados irmanados pela condição de subdesenvolvimento.

Quanto a este distanciamento estético da matéria social tratada, vale citar a primeira estrofe do poema "Romance de Salatiel", que narra a cena de um funeral, a partir da imagem do rosto do defunto:

17 Pensamos sobretudo nas ideias de Hugo Friedrich (1978, p. 07-36) e sua definição da lírica moderna - ou de uma das variantes dessa lírica, como corrigem seus críticos, dentre eles Michael Hamburguer (2007) - e também nos poetas que marcaram esta geração: Eliot, Mallarmé, Valery, todos eles questionando os tenros limites da linguagem, sobretudo do discurso poético, para fora dela mesma. 
Se foi triste, se não foi, se gostou de olhar o azul, se sofreu por desamor, se digeriu a contento, se procurou Deus (achou-o?), não conta mais. Salatiel já é a matéria sem gana que se oferta, horizontal, aos olhares e aos pêsames.

(MELLO, 1984, p. 67)

Como dissemos, várias mudanças se processarão na poesia de Thiago de Mello na medida em que ele se aproxima da militância política. Enquanto se processam alterações em sua visão de mundo, ocorrem também mudanças em sua poesia: no lugar da linguagem castiça, dos vocábulos justos, bem medidos, ele dará forma, sobretudo a partir de Faz escuro mas eu canto (1966), a um obcecante desejo de comunicabilidade. Sendo a alardeada "conscientização mobilizadora das massas" a finalidade maior desse momento de comprometimento político, o poeta se esforçará para simplificar o vocabulário e a sintaxe, experimentando um tom de cordial fraternidade para com o leitor, em substituição ao que antes era manifestação individualista, especulativa, alheia aos acontecimentos e problemas imediatos.

Apesar disso, diferentemente de Ferreira Gullar, as mudanças que engendra na forma literária jamais serão radicais, pulverizantes ou, como o poeta maranhense chega a esboçar, “suicidas". Permanecerá, em sua expressão poética, o mesmo desenho comedido e sóbrio dos versos, a mesma adesão às cadências tradicionais. O apoio da métrica não será jamais abandonado, mal e mal o poeta flerte com o verso livre com alguma constância, beirando a prosa poética. Por fim, se observará uma mudança drástica em seu rol de assuntos e na maneira como a voz lírica os desenvolve: a preocupação recorrente com a morte se transformará, a partir da conversão política, em cantos celebratórios da vida; o sentimento de comedida melancolia, nunca confessional, mas constantemente repisada em seus primeiros livros, se metamorfoseará num compromisso pactual com a alegria, encarada como ponte para a fraternidade e alimento da luta social - jamais aparecerá, nem nos duros anos de exílio, nem na doce nostalgia que seus poemas de velhice deixam transparecer, algo que se compare a um poema como "Cantilena Triste" (MELLO, 1984, p.46) e outras elegias amargas contidas nos livros anteriores a Faz escuro mas eu canto. A angústia só será matéria de seus versos quando ligada ao coletivo ou, parafraseando um outro poeta de seu tempo, ele só sofrerá as dores de seu povo (NERUDA, 1992, p. 342).

São essas mudanças em sua visão de mundo e na concepção de poesia que tornam possível o "olhar para fora". E este "para fora" equivale tanto a olhar para além dos dramas do sujeito e descobrir os conterrâneos que vivem na pele as feridas da injustiça social, como também olhar para 
além das fronteiras nacionais e encontrar uma situação que se repete nos mais variados países do terceiro mundo. Desse modo, a partir da guinada que sua poesia dá em nome dos menos favorecidos e de uma causa política de base socialista, poderemos acompanhar o espaço privilegiado que o diálogo com a América Latina adquire na poética do escritor do Amazonas.

Passemos agora para a obra de Ferreira Gullar. O poeta maranhense costuma explicar em suas entrevistas que o modernismo não havia ainda chegado a sua capital nordestina quando ele começou a se interessar por poesia. O contato com a criação literária dava-se a partir do estudo de gramática, lendo os parnasianos "oficiais" e conhecendo a estrutura dos decassílabos, os esquemas de rima e metros da tradição. Marcado por esta concepção poética - a essa altura dada como superada nos centros intelectuais do país - o autor publica Acima do Chão, em 1950, com a ajuda financeira da mãe. Ainda em São Luís, trabalha como jornalista e, também em 1950, vence um importante concurso regional de poesia com o poema "Galo". Nisso já havia conhecido a obra de Drummond e Fernando Pessoa e vive a primeira das muitas metamorfoses pelas quais passaria enquanto intelectual e artista.

Com o convite drummondiano ao "tempo presente" e o abandono da expressão de aflições íntimas, propiciado pela obra de Pessoa, Gullar lançará em São Luís o manifesto do "antiquentismo", que convocava a todos - transeuntes, padeiros, professores... - a abandonar a poesia "quente", altissonante e retórica, preocupada com as dores e questionamentos imediatos, e encarar a poesia como um exercício mental, isto é, construído a partir de uma "frieza intelectual", termo que utilizamos algumas vezes ao comentar os primeiros poemas de Thiago de Mello. É com estas ideias fervilhando na mente que o poeta muda-se para o Rio de Janeiro. Ainda com alguns resíduos delas exercerá grande papel como crítico de arte, sobretudo de artes plásticas - aliás, atividade que mantém até os dias de hoje e que certamente é indissociável de sua atuação artística: a mão do crítico e a mão do poeta frequentemente se cruzam no decorrer de suas publicações.

Já no Rio de Janeiro, publica A Luta Corporal (1954), livro considerado pelo poeta sua verdadeira estreia para as letras. A obra pode ser organizada em alguns grandes núcleos que já demarcam as inquietudes do poeta na busca de seus motivos: primeiro os "Sete poemas portugueses", que parecem bem sintonizadas com o rigor métrico, a regularidade das rimas e a temática simbolista em voga no momento; depois uma sequência de belíssimos poemas que antecipam o tom de sua madureza, como "Galo galo", "A morte das pêras", "O anjo"; e, por último, poemas que questionam de maneira mais radical o drama da linguagem, constituídos por alguns poemas em prosa, agressivos, carregados de termos chulos, até chegar à pulverização linguística do dadaísta "Roçzeiral". Ou seja, o livro é aberto com a cadência bem ritmada dos "Sete poemas 
portugueses":

Calco sob os pés sórdidos o mito

que os céus assegura - e sobre um caos me assento.

Piso a manhã caída no cimento

como flor violentada. Anjo maldito (...)

(GULLAR, 2009, p. 7)

E termina com a linguagem furiosa, hermética e autodestrutiva de "Roçzeiral", um poema que só faz sentido (se o faz...) na leitura oral, cumprindo, em partes, as expectativas do autor em criar um poema que surgisse juntamente à linguagem que o mantém:

\section{(...) \\ OASTROS FÓSSEIS \\ SOLEILS FOSSILES \\ MAÇÃS Ô TÉRRES \\ PALAVRA STÊRCÃ}

DEOSES SOLERTES PA-

LAVRA ADZENDA PA-

LAVRA NÚ-

MERO FÓSSEIL

LE SOLÊLIE Póe

ÉL FOSSIL PERFUME

\section{LUMEM LUNNENi}

\section{U Z Z E N M}

(GULLAR, 2009, p. 57)

Desse modo, o livro é uma grande caminhada da expressão poética a partir da aflição criativa vivida pelo autor nesse período: parte de um simbolismo comedido e sofisticado, bem ao gosto das correntes que pregavam um retorno à depuração lúcida do verso, e, ao término da "luta", atinge o dadaísmo incomunicável de um poema no qual a linguagem se rompe completamente, expondo, assim, a fissura que resta ao sujeito após o duro embate contra a forma poética, um silêncio atordoado, análogo ao intransponível muro do poema de Thiago de Mello.

Neste sentido, "a luta referida no título é esforço tremendo contra a repressão, procura da liberdade que se expressa, sob metáforas, em diferentes poemas" (LAFETÁ, 2007a, p. 218). O combate é contra o academicismo esteticista dos novos poetas do período e, simultaneamente, uma radicalização das conquistas modernistas a essa altura já banalizadas enquanto instrumento renovador. Por conta disso o livro vai ser uma espécie de marco na elaboração das novas 
vanguardas artísticas que germinavam no início dos anos 1950. É graças a ele que Gullar chamará a atenção dos concretistas paulistas e contribuirá com o movimento.

Seu grande interlocutor, nesta chegada ao Rio, é Mário Pedrosa, que funcionava como ponte entre o grupo concretista de São Paulo e seus entusiastas cariocas. Ferreira Gullar, então, sai da máxima tensão arrebatadora com que terminara A Luta Corporal - o poeta assume que chegou inclusive a considerar seriamente a hipótese de não mais escrever após a crise na qual se encerra o livro - e buscará refúgio na ordem construtivista da estética concretista. Sem nos alongarmos muito neste problemático debate, apenas preâmbulo indispensável da questão que de fato nos interessa, podemos definir o concretismo como um movimento que visava inaugurar uma nova linguagem poética, capaz de ser a síntese da sociedade industrial moderna, na qual o Brasil, vivendo o entusiasmo desenvolvimentista do governo JK, começava a mergulhar. Como estética de ruptura, o movimento idealizava a superação histórica do verso, o fim da retórica romântica e pungente da qual a sintaxe literária estava invariavelmente "contaminada" e, como consequência, marcava-se o surgimento de uma arte racionalista, afim dos lances publicitários, gráficos, de modo a constituir uma "arte de exportação".

O namoro de Gullar com a arte concreta é, contudo, breve, ainda que cercado de nuances já estudadas por mais de um intérprete ${ }^{18}$. Interessa-nos, aqui, tão somente verificar a busca intensa do autor por uma linguagem nova e sua atuação nas polêmicas do período. Após a conturbada aproximação com o grupo paulista, Gullar será o grande teórico do movimento neoconcreto, que terá, além do poeta, nomes de primeira linha das nossas artes plásticas, como Lygia Clark e Hélio Hoiticica. A ruptura surgirá com base na discordância entre a autonomia da forma perante seu significado e sua articulação com a cultura; ponto este muito bem explicado por Gullar:

A teoria da gestalt afirma a expressividade da forma em si. A forma tem uma expressão, independente do que ela signifique. Eu concordava, mas, quando isso era aplicado na arte, vinha a minha discordância. Porque nenhuma forma é pura. A forma da qual a gestalt fala existe enquanto fenômeno de laboratório. Mas na vida, de fato, como na arte, as formas estão impregnadas de significados. Então, a noção de boa forma que a gestalt sugere é incabível na arte, porque não existe boa forma na arte, nem melhor forma. (GULLAR, 1994, p.7)

Se as dimensões filosóficas e políticas deste debate acabaram tornando-se datadas, o mesmo não pode ser dito das suas conquistas formais. O desejo de construir uma obra de arte autônoma, fora do âmbito da cultura, foi condenado ao ostracismo pelo absurdo que carregada; no entanto, o repertório formal fundado pelos poetas concretistas e neoconcretistas permaneceu conduzindo 18 Ver BENTO (1957), BRAIT, (1981) e JUNQUEIRA (1977). 
algumas das vertentes mais fortes da poesia posterior. $\mathrm{O}$ verso, de fato, não foi abolido, mas certo ideal de concisão, certa repulsa à pompa retórica, a utilização de elementos gráficos e a exploração consciente do espaço em branco do papel foram elementos que seguiram conquistando adeptos. Sem dúvida, foi a partir deles que Ferreira Gullar desenvolveu o estilo que melhor caracteriza seus poemas mais importantes.

Para encerrarmos esta brevíssima apresentação do cenário das vanguardas na década de 1950, e permitindo que a questão retorne fluentemente mais adiante, vale a pena citar uma breve e didática passagem do livro "Poesia e política", de Eleonora Ziller Camenietzki:

Em resumo, as divergências entre o concretismo e o neoconcretismo podem ser apontadas, de forma esquemática, do seguinte modo: o concretismo se apresentava como alternativa racionalista e universalista em contraposição a uma cultura nacional ainda romântica, retórica e espontaneísta. O neoconcretismo, ao assumir a questão da subjetividade, recolocava o problema da expressão/criação em contraposição à noção concretista de arte como produção/invenção. (CAMENIETZKI, 2007)

No final da década de 1950, Ferreira Gullar se despojava da sua confortável posição enquanto criador refinado, crítico e polemista reconhecido e membro ativo do debate mais erudito que a arte brasileira travava naquele momento, para se entregar à militância política. $\mathrm{O}$ debate estético, então, passa a ser subjugado à questão ética. Em guinada ousada, Gullar deixa para segundo plano as divagações sobre Merleau-Ponty, Pound e a fenomenologia, e se volta para os versos de cordel. Se o debate do qual era protagonista erguia-se diante das diferenças pontuais entre o concretismo e o neoconcretismo, agora sua posição era a do radicalismo político. Os manifestos que tratavam dos rumos da arte de vanguarda - debates inacessíveis, pela sua erudição, mesmo para o dito cidadão médio esclarecido ${ }^{19}$ - são substituídos pela atuação direta: arte comprometida com a revolução social.

Neste vértice da história brasileira recente, as atuações intelectuais de Ferreira Gullar e Thiago de Mello acumularam convergências que antes pareceriam inconciliáveis. A poesia genuína de Thiago, conservadora em sua forma e meditativa em sua comportada regularidade, e a poesia inquieta de Gullar, que passara pelos experimentalismos mais violentos e pelos debates estéticos

19 Uma das preocupações dos vanguardistas era complementar a divulgação das obras (através, por exemplo, das Bienais) com a apresentação didática das diretrizes do movimento. O Suplemento Dominical do Jornal do Brasil (STJB) era um dos veículos que davam escape ao debate estético em voga naquele momento. Com texto de apresentação, que almejavam "educar" os leitores para a contemplação "correta" das obras. Mesmo com estes textos, a discussão era restrita, recebendo críticas amenas, mas sintomáticas, de nomes como Manuel Bandeira e Carlos de Drummond de Andrade, que com posições semelhantes viam na celeuma concretista uma poesia restrita a ser modelo aplicado de uma filosofia estética, poesia que necessitava de manual de instruções para ser lida e que só teria algo a dizer aos estetas já adequadamente inseridos nas terminologias abstratas fornecida aos leitores pelos eruditos teóricos/poetas. Ver CAMENIETZKI (2006, p. 38). 
marcelo2867@gmail.com

pungentes no período, precisavam, naquele momento, encontrar uma forma literária que conciliasse a criação e a atuação, a expressão e a comunicação. Partindo do rosto mais ou menos formado que cada uma das poéticas já apresentavam, com seus motivos e particularidades, os dois poetas iniciaram transformações substanciais no modo de escrever e, mais ainda, no modo de conceber a poesia. Trata-se do mergulho no universo popular que daria o tom de suas criações nos esperançosos anos 1960.

\section{4- Engajamento, PCB e América Latina}

Até o ano de 1958, quando foi aprovada a Declaração de Março, o partido comunista brasileiro (PCB) mantinha a firme defesa do realismo socialista em seu front cultural. A política do partido aliciava os escritores simpatizantes da causa comunista para aderirem ao "populismo" literário, àquela altura tratado pelo dogmatismo pecebista como o único caminho válido para o escritor engajado.

Vale frisar que:

A Declaração de Março foi concebida sob o impacto internacional do processo de desestalinização iniciado pelo XX Congresso do PCUS, procurando responder, também, à necessidade de corrigir a atuação sectária dos comunistas, tornada evidente no contexto brasileiro após o suicídio de Vargas em 1954. (FREDERICO, 1998, p. 275).

Antes da aprovação deste documento, e de certa forma mesmo algum tempo depois, a política cultural de base jdanovista ditava rígidas normas de criação para a intelectualidade ligada ao PCB, tornando padrão - palavra por si só oposta à natureza do fazer artístico - uma literatura de fundo didático. Jdanov fora secretário nacional de cultura da era stalinista e contumaz defensor do realismo socialista como único modelo de arte comprometida e revolucionária, capaz de fazer frente ao suposto individualismo cínico da arte burguesa, cujos referenciais de inovação e criticidade estariam em perfeita sintonia com o pessimismo e pedantismo das classes abastada. Tal concepção se espalhou rapidamente pelos PCs de todo o mundo, posta como política oficial do PCUS, criando no âmbito da arte engajada uma geração de obras bastante contestáveis em sua eficácia doutrinária e muito criticadas em sua validade estética:

Buscava-se uma representação nítida das emoções e sentimentos humanos, mas nada que lembrasse o expressionismo burguês com ênfase deturpadora no pessimismo, o desespero e descrédito no homem e no futuro. Lançava-se ao total desmerecimento gêneros como o drama, a ópera e até a comédia de costumes. $\mathrm{O}$ universo temático deveria estar restrito à vida operária e camponesa. No caso do 
gênero histórico, valorizava-se apenas o que retratasse o processo revolucionário. Enfatizava-se o caráter pedagógico das obras épicas para a devida formação comunista dos trabalhadores. (CAMILO, 2001, p. 74)

A cartilha jdanovista gerou constrangimentos e debates duros no interior do próprio partido. Nos casos mais emblemáticos, Carlos Drummond de Andrade e Rachel de Queiroz abandonaram a militância partidária em decorrência da pressão para que suas obras se encaixassem dentro da estética defendida pela direção partidária. Após a ruptura, ambos sofreram uma intensa perseguição e foram vítimas de calúnias mordazes nos veículos da mídia comunista. O mesmo vale para autores como Manuel Bandeira e Mário de Andrade. Ocasionalmente os dois poetas demonstravam certa simpatia, ainda que desconfiada, pelo ideário socialista, mas em virtude da intensificação do dogmatismo cultural tornaram-se críticos ferrenhos do PCB, expandindo esta repulsa ao próprio ideário socialista, após a intromissão partidária no fazer literário. O proselitismo colocou uma questão candente no cenário intelectual: afinal, estariam dispostos os artistas de esquerda a abandonar a busca por uma linguagem própria e aceitar o modelo uniforme de arte forjado e imposto verticalmente pelo partido?

É neste contexto de polêmicas e ânimos acirrados que a poesia de Thiago de Mello e Ferreira Gullar passam por um intenso processo de "descoberta" do mundo social. Embora não estivessem ainda filiados ao PCB em finais da década de 1950, ambos tinham uma participação efetiva em atividades por ele orquestradas. Gullar era figura em ascensão na UNE (União Nacional dos Estudantes) através dos CPCs (Centro Popular de Cultura), do qual viria a ser presidente. Thiago de Mello, por sua vez, era amigo íntimo de Ênio Silveira - dono da Editora Civilização Brasileira, que seria uma espécie de braço forte do partido na cena editorial - além de colaborador assíduo dos jornais de esquerda.

A adesão à poesia propagandística por parte de Gullar e Thiago ocorre, naquele momento, não por uma imposição tácita do PCB - como ocorreu com Drummond e Rachel de Queiroz, que não aceitaram a pressão do partido - mas pela confiança no papel que a arte parecia ter a desempenhar nos rumos da revolução brasileira. Gullar e Thiago demonstraram, numa breve etapa de suas trajetórias, convicção na validade histórica dos preceitos fomentados pelo partidão e, ao contrário do que já foi dito muitas vezes por vários de seus intérpretes, tal entrega não poderia ser simplesmente ingênua, pueril e demagógica.

Afinal, Gullar já era um crítico reconhecido, protagonista de um dos debates mais espinhosos da cultura brasileira recente, e Thiago de Mello, num outro caminho, também já conquistara um espaço como poeta dos mais talentosos, com um estilo seguro e referendado apreço 
formal já aplaudido em cinco livros de considerável reconhecimento pela crítica da época.

A entrega à poesia de viés populista, muito próxima ao panfleto, se dá numa análise mais ou menos ampla das forças que se opunham, em franca tensão, no horizonte da produção cultural brasileira. Por isso, mesmo tendo ambos, anos mais tarde, revisado, criticado e, no caso de Gullar, até condenado o entusiasmo militante com o qual se entregaram ao engajamento poético, seria uma simplificação brutal considerar este momento de entrega simplesmente como uma passagem turva e irrelevante na trajetória brilhante de Ferreira Gullar ou como o momento em que Thiago de Mello perdeu-se para sempre da boa poesia, como costuma geralmente circular, de forma cristalizada, na fortuna crítica dos autores ${ }^{20}$. Do ponto de vista crítico, aceitar a imposição política de um modelo artístico qualquer é tão danoso como referendar, de antemão, que toda adesão a este modelo seja invariavelmente espúria.

Em outros termos, para a literatura engajada, vale muito a afirmação proposta por Benjamin Abdala Jr:

As séries superestruturais, da mesma forma que a realidade político-social, não se fecham a conceituações meramente rituais: seus efeitos, certamente não desejados para esta perspectiva militante de "combate", seriam paralisantes. Se a prudência, ainda numa situação de consolidação do poder nacional, pode pedir soluções pragmáticas, estas não podem ser apriorísticas, dogmáticas, determinando a conduta artística, uniformizando-a num figurino. Se um projeto é necessário ele deve prever a diferença produtiva, a abertura crítica. (ABDALA, 2007, p. 107).

Nos termos da produção poética dos autores, apenas os Romances de Cordel (1967), de Gullar, funcionam realmente como um desenvolvimento mais sistemático da cartilha jdanovista. Nos ensaios críticos que formulou no período, ele defende a arte nacional, ataca duramente o formalismo, a autonomia da arte e defende com convicção o papel renovador que a literatura teria a contribuir com o desenvolvimento social. Mesmo assim, são raros os momentos em que sua poesia se debruça ao panfletário. Fora da experiência com o cordel - que são desde sua origem marcados como uma contribuição política, por isso já concebidos à margem da criação central do autor Gullar não abafará facilmente suas expressões particulares, trazendo quase sempre um tom inovador

20 Os ensaios de João Luiz Lafetá (2007a) e Heloísa Buarque de Hollanda (2004) são exemplos dessa "unanimidade com algo de exorcismo" (SCHWARZ, 1999, p.219) que se formou em torno dos CPCs e da série Violão de Rua, publicação poética do movimento. Lafetá, segundo Camenietzki (2006), se afasta da poesia de Gullar para desenvolver o conceito de "populismo literário", não conseguindo relacionar satisfatoriamente os problemas que detecta no pragmatismo cepecista ao universo peculiar da poesia do autor maranhense. Já no trabalho de Heloísa Buarque de Hollanda o problema decorre da escolha dos poemas que utiliza para discutir a questão do engajamento e didatismo na poesia dos CPCs. Munindo-se de uma verdadeira antologia dos poemas mais simplórios e simplistas da Violão de Rua, a autora apresenta seu severo julgamento da experiência cepcista, apontando, com bastante pertinência, seus limites e devaneios, mas sem inserir no debate poemas desta mesma série que contrariam o cenário catastrófico, em termos artísticos, por ela proposto. 
à sua militância poética. Por isso, é totalmente válida a constatação de Lafetá ao observar que para os poemas de cordel escritos por Gullar "os recursos retóricos são mais importantes que os poéticos" (LAFETÁ, 2007a, p. 229), enquanto que nos livros propriamente autorais, a matéria poética está no centro das reflexões do artista, ainda que em contínuo atrito com suas aspirações políticas.

O espaço ocupado por estes poemas na fortuna crítica de Gullar sinaliza que a aventura do poeta pelo cordel não trouxe contribuições significativas para a poesia brasileira, não sendo portanto uma apropriação criativa desta forma tradicional. Tampouco deixou contribuições para o próprio gênero popular do cordel, já que o desejo de reverenciar a cultura popular impedia qualquer alteração formal inovadora em sua estrutura. Entretanto, não parece se tratar de um mero "desvio", ou de um retrocesso, como defende, por exemplo o próprio Lafetá (2007a, p. 62) e sim de uma concessão do poeta ao militante, visto que o poeta não deixou de produzir sua obra central paralelamente aos cordéis. Ele inclusive escreveu, na mesma época dos romances de cordel, poemas centrais do livro Dentro da Noite Veloz (1974), vários deles aplaudidos por essa mesma parcela da crítica.

São quatro as peças que compõem os cordéis escritos por Ferreira Gullar: "João da BoaMorte: cabra marcado pra morrer", "Quem matou Aparecida? História de uma favelada que ateou fogo às vestes", "Peleja de Zé Molesta com Tio Sam" e "História de um valente". A gama de personagens abrange as diversas vítimas do sistema capitalista, as quais eram incitadas a seguir os exemplos dos heróis, numa linha literária de forte base lukacsiana, representados nos poemas. Assim:

Os "romances" focalizam tipos brasileiros de humilhados e ofendidos: o camponês a quem se nega a oportunidade de trabalho; a doméstica seduzida e engravidada pelo patrão, depois prostituta e suicida; o cantor cearense, franzino, que leva todo mundo na esperteza, inclusive o Tio Sam; e o militante revolucionário, no caso, Gregório Bezerra, cuja coragem e generosidade são apontadas como exemplos para o povo. (CAMENIETZKI, 2006, p. 103)

Já Thiago de Mello, por estar menos envolvido no cotidiano do partido, terá um envolvimento bastante peculiar com o dogmatismo pecebista: o seu Ponderações que faz o defunto aos que lhe fazem o velório (1960) é, sem dúvida, marcado pelo modelo valorizado pelos comunistas: retrata personagens pobres em situações heroicas, questiona a divisão de classes, a exploração e instiga no leitor a necessidade de superação da ordem vigente como única forma de suplantar a alienação do personagem central, morto sem de fato ter podido viver a vida ${ }^{21}$. No 
entanto, para além de um compromisso social mais visível, há uma manutenção do estilo grave e meditativo que o caracterizava, além de uma dificuldade em se aproximar da vida em sua concretude material, isto é, o poeta ainda se mantém numa distância confortável do coloquial e do prosaico. Essa timidez, aliada a uma abstração carcterística, persistirá em toda a produção de Thiago de Mello. Se comparado com o hiper-realismo incisivo de Gullar, os poemas de Thiago ficam sempre com uma aparência de solidariedade piedosa, de adesão afetiva ao que sofre, sem que o rosto do explorado se formule ou a causa de sua dor estremeça o conforto e a segurança do leitor.

A situação é curiosa: Ferreira Gullar de fato se entregou mais profundamente à aventura cepecista, a encenação da revolução através da poesia e a certo "populismo literário", mas é em Thiago de Mello que os efeitos da crença na linguagem lírica como instrumento capaz de alterar a realidade social permanecem intactos por mais tempo. Se para Gullar a instrumentalização da poesia a serviço de um projeto político é breve e rapidamente problematizada (já em 1970 vai dizer que "a poesia não move o pau de arara"), na obra de Thiago ela vai se desenvolvendo gradativamente, de forma duradoura, sem jamais perder de vista o ethos solidário e convocatório de sua voz lírica carregada de piedade e luz.

No final dos anos 1950, momento de iniciação na poesia comprometida por intermédio direto do PCB, há nos dois poetas - cada um a seu modo - um compromisso conscientizador, mediado por uma forma simples, zelosa em ser acessível às massas $\underline{22}$. O desejo de dialogar com os mais humildes abre um novo campo para que os poetas, tradicionalmente representantes das classes dominantes, conheçam a dura realidade do campo e das indústrias. Cria-se, assim, um sentimento que é, ao mesmo tempo, repleto de euforia e culpa. O que se mostra na forma adotada - os cordéis de Gullar são uma reverência às manifestações genuínas deste povo marginalizado - ou na própria tematização, como se nota também na "Cantiga de Claridão”, de Thiago de Mello:

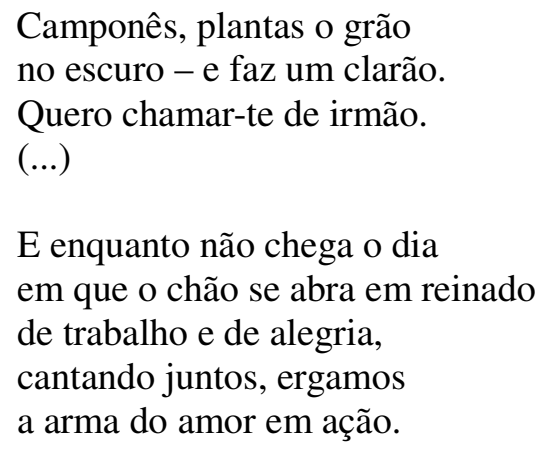

dois importantes poemas de Gullar partem mais ou menos desse motivo ("Notícia da morte de Alberto Silva" e "Homem Comum"), além de uma porção de exemplos na música popular, como "Construção", de Chico Buarque, "Pequeno perfil de um cidadão comum", de Toquinho e Belchior, e uma série de outras manifestações.

22 Heloísa Buarque de Hollanda (2004), em ensaio já citado, chega a falar em "tradução" deformadora do estilo poético para a sintaxe comum. 


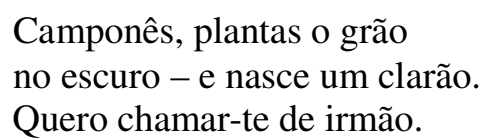

(MELLO, 1984, p. 228-229)

O desejo de irmandade, o horizonte utópico, a conclamação alegórica à luta política, além da representação de um personagem típico, o camponês, são traços que aproximam o poema do modelo lírico praticado por boa parte dos poetas engajados do período. A simplicidade também aflora: as rimas simplórias em "ão", a forma "cantiga", marcam a desejada simplicidade do poema, seu ritmo fácil de apreender, oposto à sintaxe elegante e o vocabulário rebuscado que é comum em seus livros anteriores.

A metáfora da semente indica a chegada de um tempo futuro, redentor, mas que não se desenvolve passivamente, pois precisa ser erguido no presente, isto é, na imagem do plantio. O camponês é o personagem a quem o poema prega suas promessas e presta sua solidariedade; é ele também o vértice da pirâmide em que se projetam as metáfora do campo ("grão", "semente", "plantio", "colheita"). O jogo entre claro e escuro é outro recurso utilizado no poema para simbolizar a passagem de um tempo presente ("escuro") para o tempo iluminado da utopia, que emerge como um clarão - este "clarão" está reforçado pelo grupo de palavras com as quais rima ("grão", "clarão", "irmão", cujo atrito entre as fricativas e a cadeia de nasais finais simulam a visualidade da luz repentina e forte, deixando no ar uma outra palavra que parece contida subliminarmente no trecho: "trovão"). Diga-se de passagem, o jogo entre luz e sombra será muitas vezes retomado do decorrer de nossa argumentação, visto ser um clichê característico da obra de Thiago, exaustivamente reordenada em quase todos os seus poemas. Por fim, o desejo de comunhão entre o "eu" (o intelectual, o artista) e o homem comum do campo, com quem o poema busca se comunicar, redimindo-se talvez de seu rebuscamento anterior.

É possível, ainda, ler nas entrelinhas do verso "Quero chamar-te de irmão" o sentimento de culpa acumulado, de negligência passada em relação aos explorados, que agora emerge como personagem central do poema. A forma poética é revertida para confirmar o desejo de irmandade: ela é simplificada para que o diálogo proposto no âmbito do conteúdo não seja impedido pelo descompasso da forma. A vigilância excessiva, quando não o auto-patrulhamento, acaba reduzindo o poder expressivo do poema, tornando banal a sua promessa e pouco convincente o seu chamado. Eis o projeto por trás da simplicidade primária do poema, alvo de críticas e limite de sua dimensão estética mais rigorosa.

Em termos de proposição teórica, podemos dizer que o fascínio dos intelectuais ligados aos 
CPCs pela cultura popular não negava a constatação de que essa cultura, por conta do domínio e da opressão, apresentava um fundo alienado. É dentro deste movimento que está a chave para a compreensão do movimento cepecista: caberia aos autores ligados ao projeto revolucionário partir desta cultura legítima, acessível e positivamente popular para, de dentro dela, alcançar uma matéria questionadora, que denunciasse as condições precárias e a exploração destas camadas da sociedade, "educando-as" para a luta política. Eis aí o fundamento básico do que seria a "arte popular revolucionária", tal como apresentada no "Anteprojeto do Manifesto do Centro Popular de Cultura" (apud HOLLANDA, 2004): uma "forma popular atrasada" fecundada pela consciência de classe e pela ideia de futuro próspero preconcebida pelos autores empenhados na conscientização do "povo". Ideias complexas do debate político e das terminologias marxistas travestidas numa forma popular com uma história e desenvolvimento próprio, pouco conhecida por esses poetas, na grande maioria citadinos, vindos de uma formação literária canônica.

A dimensão estética dessa poesia, como não poderia deixa de ser, passa a ser drasticamente abalada na medida em que é suplantada pela questão ética; a validade da obra não quer localizar-se mais no ordenamento intelectualizado e expressivo da matéria linguística e sim no papel que dispõe a exercer em determinado contexto social, como defendeu o próprio Gullar:

Se, como acreditamos, as obras de arte refletem conceitos, pontos de vista sobre a realidade, a função social do artista deve ser deduzida da influência que possa ter o significado global de sua obra no processo social(...). Uma obra pode estar tecnicamente muito bem realizada mas, por seu significado, ser menos válida do ponto de vista social que outra. (GULLAR, 1966, p. 38)

Em Cultura Posta em Questão (1966), temos uma elaboração consistente da reflexão que Gullar desenvolvia a respeito da participação direta do "artista-cidadão". No trecho citado, encontramos em primeiro plano o desapego ao formalismo. Para o autor, era a obsessão hedonista pela questão da forma que restringia a circulação dos textos eruditos a membros de uma diminuta elite letrada. A “arte revolucionária”, de viés popular, crítico e comprometido, não perderia de vista a questão dos procedimentos literários, mas estes estariam subordinados ao compromisso ético que a obra exerceria no meio social. Visando abafar discussões estéreis sobre a "alta literatura", o escritor empenhado pregava a necessidade de que os intelectuais tomassem partido na práxis, colocando seus conhecimentos à disposição do ideal revolucionário. Para esse conceito de poesia, capaz de definir um novo estatuto para o poeta, é evidente que não há espaço nem para as discussões vanguardista que Gullar travara nos anos 1950, nem para a "poesia aristocrática" que Álvaro Lins observara como grande virtude do estreante Thiago de Mello.

Animados por esta proposta, os poemas de Gullar abandonavam, momentaneamente, a 
posição central que a depuração estética e a inquietude formal ocupavam em sua reflexão artística. $\mathrm{O}$ embate contra a linguagem e a polêmica em torno de conceitos finamente sutis tornam-se inócuos diante do comprometimento político. Longe dos desgastados debates vanguardistas, Gullar cumpria importantes tarefas na prática educativa dos CPCs com seus versos de Cordel:

\section{(...)}

Morava João nas terras de um coronel muito rico. Tinha mulher e seis filhos um cão que chamava Chico, um facão de cortar mato, um chapéu e um tico-tico.

Trabalhava noite e dia nas terras do fazendeiro. Mal dormia, mal comia, mal recebia dinheiro; se recebia não dava para acender o candeeiro. João não sabia como fugir deste cativeiro. (...)

(GULLAR, 2009, p. 111-112)

Neste poema a valorização da cultura popular aparece especialmente na utilização do cordel como forma literária. O tom épico favorece a descrição dos sofrimentos dos camponeses, sua tomada de consciência e tentativa de resistência frente às forças sociais pelas quais está subjugado. Da exploração à revolta, os cordéis de Gullar, em conformidade com as intenções políticas do autor, tecem uma narrativa que exibe, realisticamente, as condições adversas das vítimas do latifúndio e, como consequência pedagógica dessa denúncia, valoriza a tomada de consciência da personagem, o João Boa Morte.

Tomada de consciência e mudança social andariam juntas, numa crença exagerada de que bastaria ao intelectual cumprir sua função de "educar" as classes exploradas para que a revolução viesse a galope. A poesia se imbuía da grande missão de ser este canal transformador e, neste aspecto, Heloísa Buarque de Hollanda é dura ao fazer o balanço da poesia de aspiração popular e seu desejo de conversão das classes mais pobres:

Poeticamente, esta opção traduz-se numa linguagem celebratória, ritualizada, exortativa e pacificadora. O laborioso esforço de captar a 'sintaxe das massas' significa para o escritor a escolha de uma linguagem que não é a sua. Programaticamente ele abre mão do que seria a sua força, a palavra poética - seu único engajamento possível -, em favor de um mimetismo que não consegue realizar, não levando, inclusive, em conta o nível de produção simbólica nessa mesma poética popular. Produz-se, então, uma poesia metaforicamente pobre, codificada e esquemática. (HOLLANDA, 2004, p. 62) 
Naturalmente, como já vimos, renegar em bloco esta concepção de poesia pode ser um exagero. Ao lado de uma leva de poemas facilmente olvidáveis e outros amplamente bisonhos, alguns deles citados no texto de Heloísa Buarque de Hollanda, este engajamento elementar, esta aproximação entusiasmada do popular, serenando seus excessos mais gritantes, gerou também sempre, é claro, com as especificidades de cada um deles - páginas notáveis como um Morte e Vida Severina (1955), alguns poemas de Vinícius de Moraes e do próprio Gullar, além de várias das letras mais importantes da música popular brasileira, para ficarmos somente nos exemplos mais conhecidos.

Além disso, e sem assumir a ingrata tarefa de defender a poesia cepecista, a experiência dos centros populares de cultura propiciou um contato direto dos autores com as classes sociais tematizadas nas obras. Longe de ser a encenação demagógica da celebração de uma camada pobre que os intelectuais jamais conheceram efetivamente, o CPC propiciou uma vivência prolongada com estes atores e tal conhecimento testemunhal da realidade social, com suas injustiças e revoltas. O debate sobre os problemas do Brasil e a descoberta física e arrebatadora daqueles que os vivem mais intensamente seria imprescindível na fase de madureza dos autores estudados e de tantos outros. Quando a militância literária volta a exigir uma linguagem pessoal e o drama da expressão retorna à cena, em tensão com a consciência crítica conquistada, este momento ganhará uma importância fundamental na compreensão das obras seguintes.

No poema "Ponderações que faz o defunto aos que lhe fazem o velório", de Thiago de Mello, já não há apropriação de gêneros populares, mas a forma narrativa prevalece; o personagem central é também das camadas pobres e, no leito de morte, faz um silencioso apelo aos vivos para não gastarem, entre cansaços e obediências, a vida que lhes é dada:

$$
\begin{aligned}
& \text { Não vou dizer a palavra } \\
& \text { essencial: a que resuma } \\
& \text { o segredo e indique o rumo. } \\
& \text { Contudo parto seguro } \\
& \text { de que amanhã vai chegar } \\
& \text { e meu povo será poder. }
\end{aligned}
$$

(MELLO, 1984, p. 194)

Tal como nos Romances de Cordel, a consciência da exploração e da não plenitude da vida gera o desejo de transformação da realidade. Não obstante, é fácil observar, desde já, uma sintomática diferença no modo de expressão dos poetas: em Thiago de Mello a atmosfera é toda abstrata; mesmo quando trata da realidade dura, do sofrimento causado pela injusta distribuição de riqueza, sua linguagem deixa-se impregnar de uma dimensão piedosa, mais de uma cumplicidade 
cristã do que de crítica efetiva. Ao contrário disso, Gullar evitará qualquer efusão lírica, qualquer sentimentalismo derramado, mantendo um coerente materialismo que, como sugere Alfredo Bosi (2004), funciona como espécie de fio condutor das suas diversas, e radicais, escolhas formais.

Assim sendo, durante o momento de maior participação no engajamento literário, o que em Gullar será violência e revolta, em Thiago será solidariedade e compaixão; o que em Gullar será punhos, movimento, detritos, em Thiago será fraternidade e anúncios otimistas de alvoradas; o que em Gullar será ânsia, vertigem, em Thiago será esperança, utopia.

Fechando esse tópico, cabe ressaltar que, com a Declaração de Março, temos a base social concreta para que esta noção populista e instrumental de poesia seja, ao menos em seu radicalismo mais constrangedor, superada. Se até finais da década de 1950 o PCB alardeava que a única maneira do escritor atuar na realidade pública, contribuindo para as desejadas mudanças sociais, era na entrega ao realismo socialista oficial, com a desestalinização dos PCs esta política é abandonada. Os escritores simpáticos aos ideias socialistas ganham uma margem maior para desenvolverem suas concepções de arte sem serem molestados pela camisa de força ideológica do partido. A esquerda se torna mais heterogênea, na medida em que o PCB perde a força de unidade e aglutinação dos vários grupos que carregavam a bandeira do socialismo, principalmente após o golpe militar, quando cai outra vez na clandestinidade.

Dentro da poesia engajada abriam-se janelas para uma diversificação dos assuntos e abordagens. Sem abandonar o comprometimento com a causa popular, os poetas ganhavam novo fôlego para incorporarem a revolta em novas combinações literárias: a memória, a rotina e até mesmo a lírica amorosa eram retomadas em suas potencialidades críticas, carregadas sempre com o tempero do inconformismo e da denúncia política.

Antes do fim da política jdanovista, a valorização do nacionalismo e da cultura popular elevada como símbolo do nacional - eram os pontos básicos a serem celebrados. A forma era dada a priori; o ethos dos personagens giravam em torno de dois ou três atributos fixos, quase sempre idealizados e estereotipados. A finalidade imediata dessa poesia era a politização dos explorados e seu fim maior, após a tomada de consciência, era a própria revolução brasileira.

Fora da esfera cultural, o PCB optara por se alinhar a uma burguesia progressista com o intuito de acirrar a luta de classes e, conforme a concepção etapista característica desta época, aglutinar forças para uma futura mudança efetiva. No que se refere aos acordos supranacionais, o único dualismo em voga neste período era o da questão nacional e sua relação com o internacionalismo proletário. Não havia, até a década de 1950, uma articulação concreta com vistas a estabelecer um diálogo entre o Brasil e os países da América Latina. Os PCs funcionavam de 
marcelo2867@gmail.com

maneira isolada, extremamente preocupados em forjar, cada um a seu modo, um modelo de nacionalismo que desse conta das complexas identidades em jogo nos países do continente. Mesmo entre os intelectuais de esquerda, valorizava-se muito mais a especificidade do Brasil na América, sua grandeza mítica, natureza exuberante, suas figuras típicas, o regionalismo, a fome no nordeste, o abandono na Amazônia, enfim, os problemas particulares do país.

A flexibilização pecebista em torno da questão da arte nacional foi o acontecimento interno para que os artistas ligados à esquerda expandissem seu rol de assuntos e buscassem na solidariedade latino-americana uma matéria poética fecunda. Deixava-se de lado a ênfase restrita ao nacional e se estimulava, ainda que indiretamente, arranjos identitários mais amplos. Logo, o PCB perderia sua hegemonia no plano cultural. A esquerda continuaria mantendo sua força no jogo cultural, mas o partido já não seria capaz de integrar as várias tendências que surgiam. Os comunistas já não brigavam mais pelo poder dentro do partido; várias dissidências se organizavam e iam desde o movimento contracultural até os grupos ligados à luta armada, do PCdoB aos movimentos de base da igreja católica, passando pelos mais diversos grupos, todos ligados a uma noção mais ou menos identificável como "esquerdista", mas com concepções e práticas tão distintas e conflitantes que seria impossível pensar numa unidade de ação homogênea com o PCB ocupando papel relevante.

Fora do país, outros acontecimentos beneficiavam o esforço comunitário. O maior deles certamente foi o impacto da Revolução Cubana. No plano simbólico, a vitória de um grupo guerrilheiro comprovava a possibilidade de vitória sobre o imperialismo norte-americano em um país extremamente próximo e totalmente dependente dos vizinhos capitalistas. Já no plano material, criou-se rapidamente uma rede de treinamento de guerrilheiros, inclusive com investimentos soviéticos, em novas guerrilhas que logo expandiram a influência cubana nas esquerdas de todo o continente. A revolução triunfante animava artistas do mundo inteiro a se irmanarem na resistência da ilha e na propagação estratégica de seu modelo. É nesta época que nomes como Che Guevara e Pablo Neruda tornavam-se familiares no nosso meio intelectual, a eles eram dedicados poemas, condecorações e amizades. Por fim, o AI-5 veio desmembrar a força esquerdista na cultura brasileira, mandando para o exílio aqueles que desafiassem a ditadura, calando a muitos, alguns para sempre. Vários dos exilados partiram para países latino-americanos. Gullar e Thiago testemunharam a esperança e a derrocada do governo comunista no Chile e circularam pelo continente conhecendo suas paisagens e problemas.

Com tudo isso formamos um painel geral com as condições que catalisaram a presença tão marcante do comunitarismo e da solidariedade cultural entre o Brasil e os países latino-americanos 
marcelo2867@gmail.com

nas décadas de 1960 e 1970. Evidenciamos, assim, o pano de fundo contextual que direcionou Ferreira Gullar e Thiago de Mello para posição destacada dentro da militância poética e passamos rapidamente a estudar, com base em cada um dos eventos apresentados, a importância que a América Latina atingirá na obra lírica dos dois autores. 


\section{2- Eixos de uma poética americanista}

\section{1- Nos labirintos da identidade}

Enquanto parte de um projeto fundamentalmente político, a adesão, por parte dos autores analisados, a um projeto/ideal de América Latina unida só ganharia forma e profundidade literária na medida em que sustentasse a ativação - ou mesmo a construção - de uma identidade continental. A causa socialista e a militância política de parte considerável da intelectualidade brasileira, conforme vimos no capítulo anterior, explicam em grande parte o projeto ideológico por trás da investida na latinidad nos anos 1960 e 1970. Não obstante, para elucidarmos o projeto estético que dá vida às obras em questão, precisamos direcionar nossa atenção para a questão da(s) identidade(s) por elas vinculadas. A simples menção a uma perspectiva comunitária tendo em vista articulações entre o Brasil e os países vizinhos se sustenta no princípio de que há, no plano da história latinoamericana, uma série de elementos capazes de justificar a integração dos países e atores sociais neles envolvidos. Tais convergências, de fundo político, econômico e cultural, determinariam uma experiência compartilhada, fomentando hábitos comuns, práticas sociais paralelas e saídas políticas dignas de serem articuladas.

Ao escritor interessado em disseminar a cooperação e o diálogo, caberia a ativação do imenso rol de imagens, tradições e sincresias sócio-históricas que permeiam o discurso da e sobre a América Latina para imprimir em suas obras o horizonte comunitário. É esta "identidade continental" reivindicada e posta em movimento na poesia dos autores aqui estudados, bem como seus fundamentos, origens, limites e abusos, que trataremos de examinar com mais afinco nesta altura da reflexão.

Tema dos mais abordados nas ciências sociais e mais recentemente foco primordial de interesse das mais diversas áreas do conhecimento, a formação das identidades nutre com a literatura uma relação de profundos contatos. O texto literário alimenta-se frequentemente de conteúdos identitários correntes, ao mesmo tempo que os recria e os expande, rasurando-os ou reciclando-os conforme as exigências de seu tempo. Há também os conhecidos casos em que o texto literário chega a inaugurar novas visões e formas de auto-representação, aglutinando em seu 
discurso atributos que modulam uma identidade coletiva antes oculta ou inexistente. É o que mostra, por exemplo, os estudos de Benedict Anderson (1989), ao comentar o papel dos romances nacionais na formação dos estados europeus modernos. Com a adoção das línguas vulgares como idioma literário e a elaboração das grandes obras de formação, os textos literários ocupavam posição destacada no imaginário matricial das novas nações, sendo um dos polos de veiculação dos discursos nacionais, chave para a coesão social e base simbólica para a justificação destes estados. Coube à literatura, neste caso e em tantos outros, contribuir para a solidificação dos espaços nacionais, ativando aspectos identitários e, depois, sendo estas obras partes indissociáveis desta mesma identidade ${ }^{23}$.

Com base nos principais teóricos que têm se debruçado sobre a questão da identidade, partiremos da ideia de observar este escorregadio conceito enquanto algo construído no e pelo discurso (HALL, 1999). A identidade estaria fundida em um modo específico de prática discursiva capaz de formular, a partir de partes mais ou menos comuns, um todo integrado, coeso, virtual e minimamente compartilhado pela coletividade, capaz de gerar em membros de um grupo social um sentimento de pertença e identificação com as práticas e costumes aglutinados neste discurso. É, portanto, a base discursiva que compõe a unidade, sempre transitória, da identidade. E à identidade cabe, por sua vez, o papel de fundar na dinâmica da práxis um (re)conhecimento coletivo, um elo de relativa segurança entre o sujeito e o grupo no qual está inscrito.

Tal visão, em voga nos estudos atuais, refuta a crença numa identidade essencial, imutável, e salienta sua fluidez inerente - mais visível e radical em nosso tempo de extrema fragmentação -, seu caráter múltiplo, elaborado e re-elaborado na interação social. Desse modo, cumpre notar os interesses de quem reivindica uma identidade, pois:

As identidades são activadas, estrategicamente, pelas contingências, pelas lutas, sendo permanentemente descobertas e reconstruídas na acção. As identidades são, assim, relacionais e múltiplas, baseadas no reconhecimento por outros atores sociais e na diferenciação. (MENDES, 2002, p. 505).

No caso de algo tão abstrato e controverso como a veiculação da "identidade continental" aqui analisada, fica evidente o delicado jogo de nuances que atuam sobre o sentir-se latino-

23 Clássicos como Dom Quixote, A Divina Comédia, Os Lusíadas são exemplos de obras que exerceram posição destacada na formação dos seus respectivos estados e que se transformaram em parte constituinte das identidades nacionais. Ou seja, contribuíram de alguma forma para unidade linguística, territorial e política dos estados e, com as sucessivas apropriações de seus conteúdos pelo discurso político, tornaram-se símbolos importantes e lê-las (ou estudá-las) contribui, de algum modo, para que os indivíduos se incluam nesta coletividade. 
americano: afinal de contas, que laço seria capaz de unir, do Atacama ao Caribe, todos os indivíduos do continente numa única expressão iluminadora dos nossos problemas sociais mais espinhosos? Como reunir a grande bacia de línguas, dialetos e culturas numa palavra integradora, num projeto comum, sem ferir a diversidade e a particularidade de cada grupo? Ou mais ainda: como justificar um paralelismo sociocultural já historicamente segmentado, permeado de vários caminhos e desencontros, numa formulação simbólica que dê sentido à ação conjunta e a torne suficientemente límpida a ponto de, sem falseá-la, compensar as inquestionáveis diferenças?

Tais questionamentos vêm se impondo como sólidos desafios ao diálogo comunitário desde a formulação de uma ideia de América Latina, chegando às reflexões acadêmicas atuais envoltas por desconfianças e ceticismo. Para os mais otimistas, nenhuma das inequívocas diferenças entre os países americanos seria capaz de desestimular o interesse na busca/elaboração de uma identidade comum, que delimite nosso lugar no mundo e nos conduza à ação conjunta, marcando a sedutora expectativa de juntos sermos mais fortes e menos solitários. Já para os céticos, tal identidade não poderia surgir senão enquanto farsa, sendo invariavelmente um apelo ingênuo da demagogia política. No centro do imbróglio, como vemos, está a legitimidade ou não desta identidade colocada em questão, validade ou não de um discurso que tantas vezes desliza do debate político para o plano da cultura e, logo, para a literatura.

Outro dado importante é que havendo em nosso tempo "identidades múltiplas, concorrentes e interligadas" (HALL, 1999, p. 24), não poderíamos falar em circulação de uma identidade latinoamericana contida, idêntica, na poesia de Ferreira Gullar, Thiago de Mello e demais poetas que a exploraram. O que temos, de fato, são várias identidades em constante atualização, ora se complementando, ora negando e refutando umas às outras. Na elaboração estética do texto poético, mesmo quando recolhidas de uma aspiração política comum, as identidades em jogo serão literariamente tão distintas como os estilos dos autores e suas visões de mundo.

Dois poemas dos autores analisados serão agora lidos por nós como exemplos paradigmáticos deste debate. Em "Nós, latino-americanos", de Ferreira Gullar, e "O coração latinoamericano", de Thiago de Mello, a diferenciação quanto aos princípios que regem o esforço solidário aparece de forma extremamente interessante. Embora, grosso modo, os dois poemas partam de uma base comum que funda a identidade latino-americana em torno da paisagem social isto é, da pobreza e dependência econômica - e histórica (o passado colonial e o projeto libertário) 
por trás deste fio maior encontramos diferentes formas de refundá-la na linguagem poética.

Por terem feito parte de um primeiro momento da militância poética, vigente até meados dos anos 1960, no qual o grande projeto literário era a constituição de um nacionalismo de fundo popular, os dois poetas acabam tendo, num segundo momento, o grande desafio de conciliar uma identidade nacional, a partir da visão já consagrada pelo modernismo brasileiro, com uma posição supranacional, ou seja, com um olhar que questiona a posição do Brasil no cenário global, com a América Latina aparecendo como horizonte privilegiado para a aproximação. Tudo isto articulado também com linhas mais "regionais", já presentes no chamado "romance de 30" e no discurso da sociologia, que marcam a delimitação da diversidade, de vários Brasis dentro do Brasil, que na poesia emerge como espaço particular do sujeito, o local de onde ele dialoga tensamente com os centros nacionais e que é liricamente fundado como o chão sobre o qual emana o cosmopolitismo dos poetas. Em outras palavras, estamos falando do próprio tópico da cidade da infância - o Amazonas fluvial de Thiago de Mello e a São Luis "quente e realíssima"24 de Gullar - espaços distantes dos centros econômicos brasileiros para onde convergem as lembranças mais remotas dos sujeitos. A dimensão "regionalista" contida no tópico da cidade da infância retornará ao debate com maior ênfase no capítulo final do trabalho.

Uma excelente ilustração da convivência destas três linhas (regional, nacional e cosmopolita) em nossa literatura pode ser vista em um sintomático poema de Carlos Drummond de Andrade que, não por acaso, recebe o nome de “América” (ANDRADE, 1987, p. 195-196). Nele as linhas do nacional se cruzam com o global contido no título. A “América" surge como espaço da desmesura, das infinitas possibilidades que brotam dos mapas a partir da rememoração que o sujeito faz das antigas aulas de geografia e, da mesma maneira, se cruza com a realidade mais imediata do espaço de origem, a pequena cidade mineira do poeta, abafada pela intuição do "mundo grande" ("Uma rua começa em Itabira que vai dar em qualquer lugar do mundo"). Esta "América" não é ainda a América Latina atrasada, terceiro-mundista, pronta para a necessária transformação, mas Drummond esbanja ternura no olhar individualista do sujeito que, pequenino frente ao continente, com os pés fincados na pequena cidade mineira com sua "vida besta", descobre dentro da sua solidão que também os bois, as pessoas simples a sua volta, são parte desta "América", assim como

24 A expressão é utilizada por Alfredo Bosi (2004). Para o crítico, a cidade da infância é o núcleo central e irradiador dos sentidos mais candentes da produção poética de Gullar. 
o Brasil, este gigante insondável em sua totalidade ausente, como diz em outro poema: "A gente viajando pela pátria sente saudade da pátria” (DRUMMOND, 1987, p. 36)

Analisando o poema de Thiago de Mello, descobrimos como o espaço da desmesura latinoamericana, da diversidade inalcançável, é refundado sob o signo do pertencimento. Passemos imediatamente ao poema:

\section{O coração latino-americano}

Incas, ianomamis, tiahuanacos, aztecas, mayas, tupis-guaranis, a sagrada intuição das nações mais saudosas. Os resíduos. A cruz e o arcabuz dos homens brancos. $\mathrm{O}$ assombro diante dos cavalos, a adoração dos astros.

Uma porção de sangues abraçados.

Os heróis e os mártires que fincaram no tempo

a espada de uma pátria maior.

A lucidez do sonho arando o mar.

As águas amazônicas, as neves da cordilheira.

O quentzal dourado, o condor solitário, o uirapuru da floresta, canto de todos os pássaros.

A destreza felina das onças e dos pumas. Rosas, hortênsias, violetas, margaridas, flores e mulheres de todas as cores, todos os perfis. A sombra fresca das tardes tropicais. O ritmo pungente, rumba, milonga, tango, marinera, samba-canção.

$\mathrm{O}$ alambique do barro gotejando

a luz ardente do canavial.

O perfume da floresta que reúne, em morna convivência, a árvores altaneira e a planta mais rasteirinha do chão.

$\mathrm{O}$ fragor dos vulcões, o árido silêncio

25 Poderíamos retirar diversos exemplos semelhantes na música popular brasileira. A canção brasileira dos anos 70 também se aventurou intensamente na "descoberta" cultural da América Latina e na exaltação da união solidária entre os países e seus atores. Cabe destacar, porém, que esta tendência, assim como no poema de Drummond e na poesia de Gullar e Thiago, não perde de vista a veiculação de uma identidade nacional e regional articulada livremente com a proposta americanista. Pensemos nas canções de Milton Nascimento, tão interessadas na representação poética da "mineiridade" como no entusiasmo de uma latinidad várias vezes retratada em suas gravações ("Volver a los diecisiete", "Gracias a la vida"). Mais visivelmente ainda, a música "Sou apenas um rapaz latino-americano", de Belchior, lançada em 1974, assume abertamente esta identificação latino-americana em seu refrão, mas este sentimento de pertença emerge justamente da saga de um nordestino buscando melhores condições de vida na "cidade grande". Em todos os casos, a convivência entre estes vários níveis identitários não apresenta desconforto para os sujeitos que as reivindicam, são, como explicou Stuart Hall (1999, p. 16) múltiplas. 


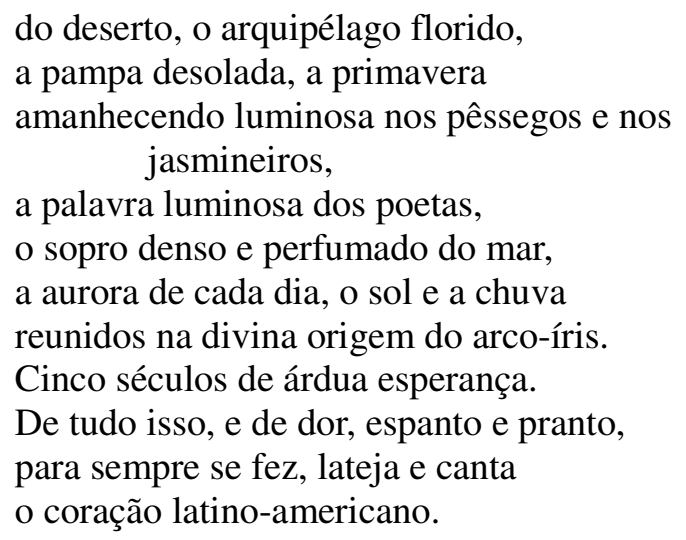

O poema de Thiago de Mello está presente no livro De uma vez por todas, publicado em 1996. Trata-se, portanto, de uma elaboração tardia que representa a mais detalhada definição do que seria, na ótica do poeta do Amazonas, a identidade continental que inspira vários de seus cantos. Embora a América Latina seja tema dos mais profícuos para o autor, a ocorrência do tema em sua obra é abundante principalmente quando trata de personagens/amigos do continente ("Canção para Victor Jara", "Canto a Nemésio Antunez"), paisagens ("Água de remanso", "Mormaço de primavera") e acontecimentos históricos do continente ("O cupim nos esteios", "O que me espantou").

"O coração latino-americano" é o único dos seus poemas em que a identidade que orquestra o diálogo americanista está formulada com grande fôlego, sendo o poema inteiramente dedicado a difundir a visão de uma pretensa unidade continental. Ele está contido em um livros mais recente, posterior ao período de maior recorrência da latinidad na poesia brasileira. Por isso não pode deixar de ser lido como uma espécie de síntese do sentimento que o poeta profetizava desde Faz escuro mas eu canto (1966) demonstrando constante fascínio pela América Latina, seus símbolos e seu povo.

Nota-se que no poema em questão o sentimento de pertença brota, metonimicamente, do próprio coração, de uma forma natural e contínua, que pulsa e se coloca em estado de comunhão com os índices semânticos que definem a identificação:

O fragor dos vulcões, o árido silêncio

do deserto, o arquipélago florido, a pampa desolada, a primavera amanhecendo (...)

De tudo isso, e de dor, espanto e pranto, 
para sempre se fez, lateja e canta

o coração latino-americano.

A estrutura do poema apresenta uma única e longa estrofe, estendida do primeiro ao último verso. Algumas palavras são isoladas, aparecendo solitárias em versos menores. Este recurso cumpre a função de dar destaque visual à certas expressões e contribui para tecer um fio que, ligado à regularidade do ritmo, liga os vários núcleos do poema. "Tempo", “cordilheira”, "pássaros", "samba-canção" e "jasmineiros" são as palavras, semanticamente conectadas, que se desmembram do grupo ao qual estão sintaticamente subordinados e "escorregam" para o verso seguinte, nos quais estão marcadas pelo isolamento e pelo recuo da página. Este procedimento contribui para reforçar a cadência do poema, na medida em que a quebra dos versos mais longos guia o tempo plácido da leitura, retificando o tecido harmônico do conteúdo, ou seja, da identidade que se expressa.

Os vários grupos semânticos que constituem a ampla cadeia de dados justapostos contêm, cada um, vários signos com forte teor identitário que vão sendo elencados de maneira aparentemente solta, casual. A sonoridade límpida cria a impressão de que as imagens vão brotando espontaneamente, numa única e inquebrantável corrente, tal como dita a fluência da sintaxe.

No entanto, a disposição das imagens segue uma ordem bastante sugestiva e nada aleatória: cada um dos elementos enumerados interage e complementa os que o acompanham dentro de cada núcleo que, por sua vez, fazem parte da cadeia maior do poema, que seria um quadro da própria identidade latino-americana. Dessa maneira, podemos delimitar alguns grupos: um, o primeiro a ser enunciado, que corresponde aos grupos indígenas formadores do continente, outro abarcando paisagens naturais e a geografia, outro expondo a fauna e a flora, depois os ritmos e assim por diante, sempre com imagens fortemente caracterizadoras da natureza e da cultura tradicionalmente mencionadas como típicas da América Latina.

Chama atenção a insistente aglutinação da diversidade: a extensa lista de atributos do continente se desenvolve de forma plácida, não como modo de expor a diferença entre as inúmeras culturas presentes na América e sim como estratégia de pacificar os opostos, sublimando as tensões para justificar a união. Com isso, na fluidez do poema, a variedade exuberante é sorrateiramente invertida, tornando-se um traço singular, único, identificador - monótono, poderiam dizer alguns. É com esta intenção que o poeta recorre muitas vezes à justaposição de antíteses: "as águas amazônicas, as neves da / cordilheira", "a árvore altaneira/ e a planta mais rasteirinha", "o árido 
silêncio do deserto, / o arquipélago florido". Não há nenhuma tensão perturbadora entre os elementos, embora eles se refiram a realidades e sensações opostas. Água e neve, o alto e o rasteiro, o deserto e as flores integram-se num todo maior, resultante da soma destes e de todas as outras imagens que se sucedem organizadamente no poema. Não há ruído ou impasse abalando a paz sublime destes cenários que se abraçam, se harmonizam em um todo coeso que expressa a identidade que funde os vários elementos - de ordem natural e cultural - num único "coração latino-americano".

A formulação presente no poema de Thiago de Mello nos remete a uma ideia de Roberto Schwarz no ensaio "Nacional por subtração" (1978), sempre retomada no debate sobre a cultura brasileira - e sua tese pode ser útil para refletirmos também a cerca da América Latina. O crítico nota que em nossas obras literárias a identidade é construída com base na eliminação daquilo que não é nativo, ou seja, em uma comparação tácita com a matriz europeia, o traço marcante da identidade nacional - ou se ampliarmos a sua tese, da identidade continental - seria as sobras, aquilo que lhe é único, sem correspondente na cultura europeia. O poema dialoga com esta concepção ao sugerir que a especificidade latino-americana é a sua própria condição de estar no mundo, marcando uma identidade feita de "resíduos", como chega a aparecer literalmente no poema.

A busca pelo nativo, pelo particular e a ênfase programática na natureza são desdobramentos quase imediatos desta identidade que se proclama residual. O poeta resgata, com intensos ecos românticos, a exuberância da natureza como força propulsora do sentir-se americano. São abundantemente mencionados, de maneira um tanto quanto folclórica, alguns dos animais e plantas típicos das diversas regiões do continente, assim como cintilam paisagens, florestas, danças e ritmos, além da cultura mais popular, tão bem vista pelos poetas engajados dos anos 1960 .

Enfim, é bem vindo na constelação do poema tudo aquilo que soa como genuíno, sem par nos grandes centros ditos civilizados. Coloca-se um sinal de positivo na beleza agreste e se valoriza, de maneira mais ou menos idealizada, a pujança, a grandeza, a desmesura do cenário latinoamericano, do qual se retira a crença num destino social a altura da exuberância natural sobre a qual o continente se ergue.

Retomando as contribuições do ensaio "Literatura e Subdesenvolvimento", de Antonio Candido, podemos interpretar o poema de Thiago de Mello como manifestação nostálgica de uma 
identidade elementar que historicamente cai em descrédito no início do século XX, quando irrompe uma visão crítica do subdesenvolvimento. É fácil encontrar no poema analisado vestígios das formas que Antonio Candido apontava nas manifestações literárias do século XIX, contemporâneas à independência, momento no qual:

A literatura fez-se linguagem de celebração e terno apego, com apoio da hipérbole e na transformação do exotismo em estado de alma. O nosso céu era mais azul, as nossas flores mais vistosas, a nossa paisagem mais inspiradora que a de outros lugares, como se lê no poema de Gonçalves Dias, mas que poderia ter sido assinado por qualquer um dos seus contemporâneos latino-americanos entre o México e a Terra do Fogo. (CANDIDO, 1973, p. 14)

Vale, contudo, ressaltar que estes ecos românticos convivem, no interior do poema examinado, com uma consciência da necessidade de mudança. Sendo um amálgama de diversas paisagens naturais - a floresta e a cordilheira, a onça e o puma, o deserto e o vulcão, entre outros - e diversas práticas culturais - a milonga, o tango e o samba, a palavras dos poetas, o barro dos alambiques - únicas, plenas de cores e movimentos, a identidade latino-americana só poderia, então, surgir como projeto político, como a "espada de uma pátria maior". Ao apresentar com tamanha harmonia e limpidez os mais tenros e exóticos aspectos da América Latina, o poema apresenta um desejo de igual aproximação da realidade social do continente, daí a sua originalidade: ele parte de uma análise crítica da realidade para vicejar, em seguida, uma identidade idealizada e, com efeito, aceita o risco de perder-se entre o chão da história e a abstração idealizante.

O poema, a certa altura, acaba sendo uma lista plasticamente construída de estereótipos desta identidade. Ele apresenta elementos díspares com o intuito de fundi-los e fazer da soma inverossímil de suas realidades o significado da própria condição latino-americana. Na enumeração retirada do caldeirão de imagens que representam o espaço americano, o autor resgata o projeto de heróis e mártires que anunciavam um futuro de união muito bem definido, ainda que caprichosamente longínquo ou sabidamente utópico, como "um sonho arando o mar".

Por fim, é preciso retornar ao início do poema e ponderarmos um pouco mais sobre os primeiros elementos que estalam do "coração latino-americano":

Incas, ianomamis, tiahuanacos, aztecas, mayas, tupis-guaranis, a sagrada intuição das nações mais saudosas. Os resíduos. 
A matéria indígena aparece no topo da reflexão identitária. A ancestralidade ameríndia é evocada como base étnica que daria o traço distintivo do ser latino-americano. Neste ponto, a diferença do poema em relação à idealização romântica do índio é quase nula. Nos primeiros versos, temos encenada, de maneira lírica e sintética, a formação do povo latino-americano: primeiro aparece a matriz indígena, marcada pelos vários grupos que habitavam nosso solo antes da chegada dos europeus; em seguida a chegada do homem branco, marcado pela religião católica (“A cruz e o arcabuz do homem branco") e, por fim, a luta pela independência e a mestiçagem reunidos numa única imagem bastante poderosa ("Uma porção de sangues abraçados”), na qual a mistura dos sangues estaria ligada tanto à resistência interna e ao sofrimento, quanto à vocação do continente a se integrar em laços co-sanguíneos:

\footnotetext{
Os heróis e os mártires que fincaram no tempo a espada de uma pátria maior.

A lucidez do sonho arando o mar.
}

Diferentemente do que observaremos na fulguração identitária presente na poesia de Ferreira Gullar, na obra de Thiago de Mello a explicação social e a aspiração transformadora da realidade comumente dividem espaço com uma explicação mítica do drama social latinoamericano. No poema em questão, por exemplo, o escritor do Amazonas não deixa de pintar um cenário carregado de exotismo, de belezas altissonantes e de um passado longínquo, sustentado por uma matriz comum. Os personagens da independência são elevados à condição de mártires e heróis de uma pátria unida; os grupos indígenas são resgatados como a base étnica e espiritual do novo homem que surge em nosso território, tudo isso inscrito na metáfora do coração capaz de suportar os "cinco séculos de árdua esperança" com toda a "dor, espanto e pranto" resultantes da consciência crítica e moderna do subdesenvolvimento. Os "cinco séculos" mencionados começam a ser contados, é claro, a partir do momento mítico do descobrimento da América pelos europeus.

Obviamente, a harmonia entre as diferenças, tônica do poema, é somente um artifício da linguagem, uma estratégia enunciativa bastante problemática. Lançar mão dos diversos grupos indígenas só faz algum sentido se lido numa vertente simbólica. Na prática, sabemos que eles jamais formaram um grupo coeso, sequer com práticas culturais minimamente semelhantes. Como defende o poema, há uma natureza comum e um passado que nos une; temos, todos nós, um mesmo sangue, fazemos parte de uma grande família, uma "pátria maior" - crenças que serão pulverizadas 
no poema de Gullar que leremos a seguir - e essas "verdades" são indissociáveis, nascem com o sujeito, pois brotam do seu próprio coração.

O procedimento da poesia de Thiago de Mello é semelhante ao utilizado por Pablo Neruda na constituição do seu Canto General (1992) cuja ousada ambição era ser uma espécie de enciclopédia poética da América Latina. Na ordenação do discurso nerudiano, predomina a lucidez do crítico, do poeta questionador, irmanado à causa libertária e convidando ao combate todo o povo americano, do qual o sujeito lírico ascende como porta-voz. No entanto, é a presença do mito que estrutura o longo livro, da evocação do mito fundador em "Alturas de Macchu Pichu”, passando pela celebração dos grandes guerreiros indígenas - ícones da resistência ao invasor estrangeiro - até alcançar o lirismo combatente dos últimos poemas. O efeito da explicação mítica, rigorosamente construída no livro de Neruda e presente de forma mais pontual no poema de Thiago de Mello, exerce uma função que é tanto ideológica, ao apontar para um caráter transcendente da identidade, como estético, pois ilumina a experiência social criando novos significados, dando-lhe uma roupagem simbólica, atemporal. É justamente a tentativa de alcançar uma "transcendência da identidade" ${ }^{26}$ que cristaliza o texto no tempo, que o torna inseparável das práticas sociais, acompanhado pelo ritmo grave e constante deste sujeito que não se mostra, que é quase uma voz solta, voz coletiva que reparte o legado de um coração carregado de imagens e símbolos.

O predomínio do mito e da natureza como suporte para a identidade só poderia fazer sentido para uma identificação que também se quer natural, espontânea, na medida em que a própria voz lírica oculta o caráter transitório e em permanente construção das identidades em jogo. Por isso, esses elementos brotam diretamente do coração - coração este marcado "para sempre" pela dor, o pranto e o espanto - como consequência de um passado mítico, mas também histórico, irrecusável. Eis a grande marca do poema: reduzindo o discurso identitário ao feltro estático da natureza, ele já nasce tendo o sonho da "pátria maior" como seu ponto de partida e de chegada ${ }^{27}$.

26 A noção de uma identidade fixa, duradoura, sólida, é teoricamente combatida pelos estudiosos que tratam da questão nos tempos atuais. Como explica Stuart Hall, vivemos uma era em que as identidades entram em colapso, resultando numa descentração dos indivíduos de seu lugar no espaço e na cultura e tornando, desse modo, cada vez mais tênue e fragmentária a ideia que temos de nós próprios. (HALL, 1999, p. 12-25)

27 Avessa a toda espécie de (supra)nacionalismo mitificador, Leyla Perrone-Moisés (2007) alerta para o equívoco resultante da crença de que a semelhança entre os problemas políticos e econômicos gerariam, automaticamente, paralelismos culturais propícios à integração. Segundo a autora, a exaltação do exotismo e do folclore regional enquanto símbolos identificadores da América é um erro grotesco. Embora a reflexão de Perrone-Moisés sintetize uma forte tendência dos estudos americanistas atuais, é de se notar que em alguns pontos de sua análise a vacina contra o "folclore" vem em doses altas demais: ao refutar a criação e reprodução de Macondos e Sertões Veredas, escritos para o 
Poderíamos dizer que a identidade forjada no poema, e válida para boa parte da poesia de Thiago de Mello, existe somente enquanto justificativa para uma "comunidade de vida e destino", expressão discutida por Bauman (2005, p. 17) a partir das ideias de Siegfried Kracauer. Uma comunidade de vida e destino, segundo o autor, seria aquela "dada ao indivíduo a partir de seu nascimento e dentro da qual vivem [seus membros] juntos numa ligação absoluta" (BAUMAN, 2005, p.18). A "pátria maior" referida no poema, ou o "coração latino-americano" que lhe dá nome, são arranjos discursivos que enlaçam o leitor numa adesão solidária a esse sentimento de pertença. A voz lírica que anuncia a identidade americana vem somente avisar o leitor de que ele faz parte de um irrecusável conjunto de práticas sócio-histórico-culturais correspondentes a um determinado espaço afetivo/geográfico. A identidade forjada no poema é, assim, uma consequência imediata de se ter nascido neste lugar, é o sentido que nos une, nossa condição de estar no mundo.

Desviando nosso olhar para o poema "Nós, latino-americanos" de Ferreira Gullar, veremos como ele encara a identidade latino-americana a partir de uma ótica distinta, quase oposta, a de Thiago de Mello. Primeiramente, vale notar, retomando a classificação de Bauman, a forma como a identidade presente no poema se dispõe a justificar uma "comunidade fundida unicamente por ideias ou por uma verdade de princípios" (p. 18), por isso refuta tudo que soe como "identidade inerente" e renega qualquer preceito de identificação que não seja construído socialmente, transitório, parcial. Que o diga a leitura do poema:

\title{
Nós, latino americanos
}

à Revolução Sandinista

\author{
Somos todos irmãos \\ mas não porque tenhamos \\ a mesma mãe e o mesmo pai: \\ temos é o mesmo parceiro \\ que nos trai. \\ Somos todos irmãos \\ não porque dividamos \\ o mesmo teto e a mesma mesa:
}

\footnotetext{
deleite de estrangeiros que desejam consumir uma imagem já pronta de um continente que segue uma lógica nãoeuropeia (ou que não segue lógica alguma), a autora desconsidera a difícil busca pelo particular latino-americano. É como se o constrangimento de "os de fora" nos verem em nossa diversidade descomunal fosse suficiente para invalidar tudo que possa soar exótico (isto é, sem correspondentes na Europa "civilizada") em nossa literatura, a ponto de cair no outro de extremo de elevar o intelectualismo cosmopolita de um Borges como a manifestação mais adequada, senão a única válida, para iluminar a compreensão de nosso continente.
} 


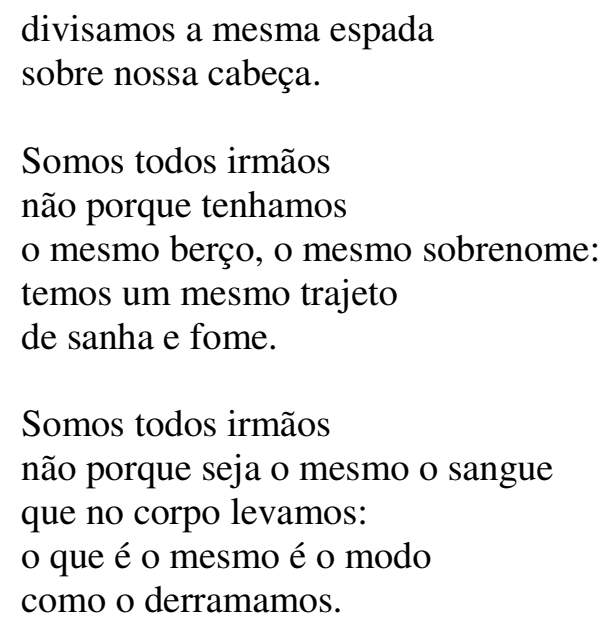

(GULLAR, 2009, p. 378)

O poema faz parte do livro Barulhos, publicado em 1987, portanto já circunscrito na fortuna crítica do autor como momento de alta maturidade expressiva. Tal como em "O coração latinoamericano", de Thiago de Mello, trata-se de um olhar mais distanciado em relação aos anos de maior atuação político-partidária e aos anos do exílio na América Latina, quando as impressões sobre os países americanos emergiam no interior de suas obras, envoltas pelo calor do momento político e pelas atribulações vivenciadas pelos poetas.

O poema não deixa de ser uma revisão do grande entusiasmo com que era debatida a latinidad nos anos 1960 e 1970, com um tom de lúcido balanço destas representações e de enfrentamento das limitações a elas impostas. Podemos observar no poema alguns traços que confirmam um estilo muito sólido conquistado pela poesia de Ferreira Gullar: por um lado a abordagem mais problematizadora da temática social, alheia aos estereótipos da poesia engajada e sem fechar-se numa abordagem dogmática da causa política; por outro lado é aprimorada a exploração da linguagem coloquial e de situações prosaicas, com a concisão e a ênfase visual no verso que são resquícios de sua apoderação crítica das vertentes vanguardistas com a qual polemizou.

O poema é dedicado à Revolução Sandinista, primeiro indício de uma solidariedade de base latino-americana, irmanada com as lutas travadas no continente. A homenagem à revolta popular na Nicarágua é o mote para uma investida nas tensões que permeiam o diálogo entre os países americanos. Neste sentido, a identificação com a luta na Nicarágua se oferece como marco evocado para se examinar critica e liricamente uma noção mais ampla de identidade. Enquanto processo revolucionário, a Revolução Sandinista representava o desejo de independência num país onde a 
maior receita econômica vinha da agricultura desenvolvida nos grandes latifúndios de propriedade norte-americana. A homenagem ao movimento, que seria violentamente contido pelas forças estadunidenses, marca no poema uma posição de adesão ao projeto de América livre, vendo na luta nicaraguense os indícios de um destino comum, libertário, tal como já anunciamos no decorrer do primeiro capítulo, e busca no compartilhamento dessa revolta o anseio transformador e o alicerce de uma identidade comum.

Podemos inicialmente afirmar que a tese fundamental de "Nós, Latino-americanos" reside na sustentação de uma identidade latino-americana. Mas seu discurso identitário não aceita, em momento algum, se refugiar na celebração ingênua de um estado de espírito absoluto e inegável de pertencimento. Numa leitura mais atenta, vemos já no título o início da tensão entre o ser ou não ser latino americano. Ela se apresenta linguisticamente por meio da ambiguidade do significante "nós", que, numa leitura mais óbvia, é lido como pronome pessoal da primeira pessoal do plural, endossando um sentido de unidade e de união em torno do qualificador comum: o ser "latinoamericano", o "nós" coral típico do canto participativo. Porém, numa outra camada de significação, secundária, embora possível, o "nós" do título assumiria o papel de substantivo e, neste caso, sua carga semântica se aproximaria simbolicamente da noção de descontinuidade, embaraço - um nó cego. Seguindo esta segunda leitura, o "latino-americano" do título passaria de substantivo, isto é, de algo fixo, estável, ocupando a posição de aposto na primeira variante, para se converter em adjetivo, marcando a fluidez típica das identidades sociais. Assim, a marca de pluralidade e congregação do "nós" pronome está em atrito com o imbróglio do "nó cego" da identidade latinoamericana. A leve fissura semântica no interior do discurso coral não suplanta, porém, os laços assumidos pela voz enunciativa, ao contrário, as ilumina. Ou nas palavras de Alfredo Bosi:

uma das marcas constante da poesia aberta para o futuro é a coralidade. O discurso da utopia é comunitário, comunicante, comunista. O poema assume o destino dos oprimidos no registro de sua voz (...) O coro atua, necessariamente, um modo de existência plural. São as classes, estratos, os grupos de uma formação histórica que se dizem no tu, no vós, no nós de todo poema abertamente político. Mas o coro não se limita a evocar uma consciência de comunidade; ele pode também provocá-la, criando nas vozes que o compõem o sentimento de um destino comum. (BOSI, 2000, p.214- 215).

A sutil ambiguidade do título já prefigura a "provocação" do ideal fixo de identidade e contribui para a (re)formulação de um "destino comum” sustentado em bases bastante originais 
para aquele momento.

O poema em si nada mais é que a encenação problemática deste jogo contínuo entre o que é fixo e o que é transitório, entre o que é dado naturalmente e o que é alcançado através de escolhas, principalmente políticas, mas também culturais. A estrutura simples, sustentada pelos paralelismos, reforça em cada estrofe a tensão entre as identidades tradicionalmente formuladas e as identidades tecidas na práxis como um horizonte de ação conjunta. Há, evidentemente, no tecido da voz lírica a confiança num princípio comum capaz de definir e distinguir o povo latino-americano dos outros povos, assim como há uma simpatia à aproximação possível dos países e a crença na convergência histórica do continente. Afinal, martela na cabeça de cada estrofe, como estribilho, a positiva convicção de que "somos todos irmãos". Entretanto, o poeta utiliza uma espécie de inversão estrutural na qual se apresenta o refrão não como clímax, mas como início, posto no primeiro verso de cada estrofe. A confiança na irmandade é ponto de partida (seu ponto de chegada não é proclamado no poema, mas fica implícito, podendo ser a revolta, a ação conjunta, a própria revolução latino-americana), um dado a priori a ser negado, desdobrado, invertido e finalmente apresentado em novos termos pelo poema.

Se o poema desenvolvesse pacificamente seu verso principal, "Somos todos irmãos", e explicasse liricamente os fundamentos desta fraternidade, teríamos, provavelmente, um resultado final semelhante ao observado no poema de Thiago de Mello: chegaríamos a uma identidade inerente, retumbante ao propagar elementos de uma cultura comum que formasse um só "coração latino-americano". Definitivamente não é o que ocorre no poema em questão: a identidade possível na poesia de Gullar não se constitui somente às margens desta visão que aqui chamamos, na falta de um nome melhor, de mítica ou "natural”, mas insurge-se contra ela.

No segundo verso de cada estrofe a adversativa "mas" - ora enunciada ora subentendida se coloca em tensão com o estribilho e o sentido fraternal que ele expressa. Cria-se uma estrutura que se repete a cada estrofe, modulando um ritmo e reforçando uma ideia, com a seguinte base: “somos todos irmãos, mas não por isso e sim por aquilo". Voltemos a primeira estrofe:

Somos todos irmãos mas não porque tenhamos a mesma mãe e o mesmo pai: temos é o mesmo parceiro que nos trai. 
Num primeiro momento não se explica o motivo pelo qual "somos todos irmãos". A queda rítmica e semântica propiciada pela posição forte da adversativa "mas" demonstra que a ordem sintática focaliza a negação: ela primeiro desconstrói a irmandade para em seguida refundá-la sob outra matiz; ela diz primeiro não, para em seguida dizer que sim, que há uma irmandade possível. O "não" é direcionado exatamente para o grupo de elementos que simbolizam a dimensão espiritual da identidade. O poema renega com veemência qualquer aproximação de ordem mítica, ancestral, sanguínea, justamente aquelas que ganham estatuto intelectual na luta pela independência e tornamse lugares-comuns com a literatura romântica. As imagens são diversificadas; cada estrofe do poema se deforma um determinado fator identitário construído pela tradição americanista, mas todos estes elementos têm algo em comum: são arbitrários, absolutos, irreversíveis.

Na primeira estrofe nega-se a importância da matriz comum. Não somos irmãos, diz o poema, por termos o mesmo pai e a mesma mãe - que podem significar o passado indígena e a colonização ibérica; na segunda estrofe nega-se o espaço familiar, com a imagem de um mesmo berço, referindo-se, talvez, à formação dos estados nacionais latino-americanos, e a mesma mesa, pondo em evidência a proximidade geográfica e o constante intercâmbio entre os países; na terceira, nega-se o sobrenome e na quarta o próprio sangue, criando uma espécie de paradoxo entre a crença na irmandade e o reconhecimento de não se ter o mesmo sangue.

Repara-se que, se verdadeiros, nenhum dos atributos poderiam ser negados, pois já nascem com o próprio sujeito. O poema não questiona exatamente a base de verdade destes termos - apenas se diz que não são eles que nos tornam irmãos - mas sim a sua validade para modular o conhecimento que temos de nós mesmos enquanto coletividade. Talvez até exista um mesmo sangue, o nome, a ascendência - não é isto que está em questão - mas tais atributos não servem para definir a conturbada relação entre os países latino-americanos, pois não se trata de uma irmandade normal, aleatoriamente distribuída, logicamente incontornável, mas sim de uma opção, um projeto baseado na análise da realidade social de cada um dos grupos e atores interessados.

Somos irmãos, retumba o verso principal de cada estrofe, mas não irmãos comuns, de mesmo berço, sangue e sobrenome, somos irmãos por compartilhar os mesmos dilemas políticos e dramas sociais, a mesma perfídia e o mesmo sangue derramado.

Dessa maneira, retomando o pensamento de Bauman, o modelo apregoado no poema não se aplica a uma "sociedade de vida e destino", tal como vimos no poema de Thiago de Mello, mas 
levanta a questão da América Latina como uma "comunidade fundada unicamente num jogo de princípios e projetos comuns" (BAUMAN, 2005, p.17). É de se supor que a poesia de Gullar, cuja base é visceralmente materialista, perderia algo de seu apelo expressivo ao abandonar a encenação poética do mito e da ancestralidade comum como justificativa espiritual para o desejo político de cooperação entre os países latino-americanos. Mais que isso, tal abandono significaria um passo para a deformidade do discurso literário e um exacerbado risco de frieza ao se reduzir a crença (ideologicamente construída) de que "somos todos irmãos" a um conjunto estreito de propaganda ideológica e arranjos políticos.

Entretanto, a habilidade do poeta reside na capacidade de fugir destas armadilhas e ser convincente, tanto do ponto de vista crítico como estético, ao salientar a base histórica das identidades em trânsito no discurso sobre o continente. O poema gera surpresa e convida à reflexão justamente por dialogar criticamente com os estereótipos que naturalizam uma imagem exótica da América Latina; ele inova ao transferir do plano espiritual para o plano político o discurso identitário, algo que poucos poetas, mesmo aqueles considerados extremamente "políticos", conseguiram acompanhar.

Ao invés da segurança de serem herdeiros de um mesmo pai e uma mesma mãe, de comerem na mesma mesa, se desenvolverem em berço comum e terem a identificação no sobrenome e nos laços sanguíneos, o poeta reduz à identidade a um único traço: a falta. $\mathrm{O}$ que nos une é precisamente aquilo que não temos e precisamos conquistar. É o parceiro que trai (referência certa ao imperialismo norte-americano), o mesmo sangue sendo derramado (ou seja, o sangue no chão e não o que corre na segurança das veias), a mesma fome, que justificam a solidariedade entre os povos do continente.

São questões que apareciam de maneira incidental no poema de Thiago de Mello, que também fazia menção a uma América explorada e sofrida ("Cinco séculos de árdua esperança”), mas que se diluíam, enquanto crítica, no painel harmônico do poema. Nos dois casos trata-se de uma concepção que atende a três momentos didaticamente marcados: a primeira apontada para o mesmo passado, marcado por surrupiamentos inglórios, extermínio da matriz indígena e domínio colonial; a segunda firmada no presente, denunciando a interferência estrangeira, personificada no imperialismo norte-americano, a desigual divisão de riquezas e a persistência do latifúndio e, por último, uma terceira via apontada para um futuro de justiça e liberdade, mediado pela luta 
revolucionária. Não obstante, o poema de Ferreira Gullar relativiza o passado e realça o presente enquanto argumento para a ação (é a fome de agora, o sangue agora derramado que justifica a união) enquanto para Thiago de Mello o passado ainda é a âncora que nos reúne numa mesma condição.

Com estas considerações, formamos um painel com as principais linhas de força que regem os diálogos latino-americanos nas obras dos poetas estudados, deixando grafada aquela que nos parece a diferença primordial entre suas poéticas. Os dois poemas que tematizam com maior fôlego a questão da identidade latina dão uma ampla sustentação para a compreendermos as representações da América Latina em seus livros centrais, publicados nos anos 1960 e 1970. Passando, agora, para a análise de poemas em que a questão latino-americana aparece de maneira mais fortuita e indireta, retornaremos, sempre que conveniente, à tese formulada a partir das interpretações aqui desenvolvidas: a América mítica de Thiago, com sua paisagem natural e conclamação à solidariedade e a irmandade espontânea entre os povos; e a América visceral de Gullar, com seu olhar desconfiado e tensa fulguração identitária, as bases materiais de seu discurso e a construção de uma identificação que é opcional, projetiva e voluntária.

\section{2- Thiago de Mello e o "Interlocutor Geral"}

A obra do poeta chileno Pablo Neruda vem sendo tratada ao longo das últimas décadas como uma das mais ambiciosas e efusivas celebrações da América Latina dentro da lírica do continente. Sobretudo em sua obra mais extensa, o Canto General, publicado em 1950, o autor elabora um audacioso canto de celebração do continente e de seu povo. De acordo com Enrico Mario Santí, o livro usa a linguagem poética para construir um amplo mosaico da América Latina, destacando, em primeiro plano, a geografia do continente, por meio do ritmo truncado e irregular dos poemas. Ganham relevo em suas páginas o sofrimento dos habitantes latino-americanos, a denúncia corrosiva da miséria decorrente da exploração imperialista, conclamando explicitamente à luta política como única solução possível para reverter a sina de desigualdade e dependência (SANTÍ, 2002, p. 12-18). A propaganda ideológica se reveste, liricamente, de uma história marginal do continente, destacando vozes silenciadas, lutas provisoriamente derrotadas, num canto extenso, 
instável e vigoroso.

O livro começou a ser concebido em viagem do poeta a Machu Pichu, símbolo máximo da América pré-colombiana, no momento em que Neruda era reconhecido como um dos principais poetas do Chile, famoso por seus poemas de amor e pela estética vanguardista de Residencia en la Tierra (1937). Durante o passeio, o poeta ainda calculava os impactos da experiência que testemunhou na Guerra Civil Espanhola, incluindo a perda do poeta e amigo Federico García Lorca. A conversão ao socialismo era um caminho em marcha e, com base nas epifanias vividas em meio às ruínas da civilização inca, o poeta funde o desejo de transformação revolucionária com uma visão integradora do continente, sendo a utopia de uma América unida um dos germens de seu canto revoltoso. A saga para publicar o livro tornou-se digna de um romance de aventura. Só foi de fato consumada no exílio, de maneira clandestina, após passar por uma intensa perseguição política dentro de seu Chile natal, na qual cruzou todo o país tentando escapar das tropas governistas $\underline{28}$. Escrito na condição de foragido político, o Canto General:

se trata más bien de una enciclopedia que reúne múltiples temas, gêneros y técnicas. La unidad de esa enciclopedia es el tema de la América: un poema cuyas dimensiones hemisféricas se identifican moral e geograficamente con el continente americano.* (SANTÍ, 2002, p 14)

A fama dos seus versos de amor, aliada à imagem combativa que tanto sua poesia comprometida como sua atuação pública tratavam de propagar, foram criando toda uma mitologia ao redor do poeta. Chegou a ser senador da república e por pouco não foi candidato à presidência do Chile - abriu mão da candidatura junto ao partido comunista em apoio à campanha vitoriosa de Salvador Allende. Por isso, desde finais dos anos cinquenta e de maneira crescente ao menos até a sua morte, em 1973, Pablo Neruda reunia um conjunto de atributos que despertava a admiração de boa parte da intelectualidade brasileira e mundial, grande parte dela marcada profundamente por ideais da esquerda.

Era irresistível para os autores politicamente engajados ter como modelo aquele homem

28 Para maiores detalhes sobre o contexto de produção do livro e a importância de Machu Pichu em sua elaboração, ver o livro de memórias escrito por Neruda, Confesso que vivi (1977), e uma de suas biografias mais detalhadas, Neruda, de Volodia Telteiboin (1996).

* Se trata mais de uma enciclopédia que reúne múltiplos temas, gêneros e técnicas. A unidade desta enciclopédia é o tema da América: um poema cujas dimensões hemisféricas se identificam moral e geograficamente com o continente americanos. 
que criara uma rica expressão poética, altamente comprometida com as causas populares; que era louvado por boa parte da crítica como poeta dos mais capacitados, sempre cotado para receber o prêmio Nobel de literatura, que iria, enfim, receber em 1971. Mais que isso, era poeta de um público amplo, inclusive alcançando uma circulação considerável entre grupos de trabalhadores humildes, público que todos os poetas militantes almejavam conquistar, quase sempre com fracassos retumbantes.

Pela força sedutora de sua obra e pela celebridade sectária das suas empolgantes aparições, Neruda converteu-se numa espécie de exemplo a ser seguido pelos poetas que desejavam algo mais que o simples artesanato do verso. Era difícil ser poeta na América Latina dos anos 1960 sem se posicionar diante dos ecos altissonantes de Pablo Neruda. As novas gerações se dividiam acirradamente entre fiéis seguidores (ou, não raro, imitadores) do pomposo estilo nerudiano e detratores ferrenhos de seu legado. Mesmo no Chile, Pablo de Rokha e Nicanor Parra - só para ficarmos em exemplos dos mais graúdos - formularam todo um receituário de contestação e superação do vate: Rokha era o líder de uma frente, quase uma cruzada, detratora do poeta ${ }^{29}$, enquanto Parra, o outro grande poeta chileno da segunda metade do século XX, formulava sua noção de "(anti)poesia" como negação ao tom retórico e laudatório de Neruda - ao menos deste Neruda mais politizado e oficialista.

Neste intenso debate muita coisa, é claro, permanecia no tom rasteiro da perseguição ideológica: os que discordavam da opção política do poeta rechaçavam com rancor a qualidade de sua obra, enquanto alguns adeptos de seu comunismo pouco se aprofundavam em seus poemas para elevá-los à condição de obras-primas da literatura universal. Havia, porém, para além disso, divergências de outras ordens: os antagonistas de Neruda surgiam mesmo dentre os poetas $\operatorname{comunistas}^{\underline{30}}$, inclusive dentro do seu próprio partido. Estes julgavam ver em sua poética pretensamente revolucionária o conservadorismo das formas superadas, o lirismo verborrágico, a imponência imagética e verbal em detrimento da abordagem objetiva da realidade social.

Se o impacto da obra nerudiana propagou-se por todo o continente latino-americano de maneira rápida e intensa, no Brasil podemos afirmar que ele foi particularmente próspero. A história

29 Para se ter uma dimensão dos embates entre Neruda e seus críticos vale a pena ler o artigo "Neruda: sus críticos y sus biografos" (SALERNO, 2004).

30 Era o caso de Pablo de Rokha, poeta assumidamente marxista e, não obstante, o maior dos antagonistas de Neruda. 
de um sólido diálogo entre Pablo Neruda e a literatura brasileira começou a ser ensaiada no ano de 1948, ou seja, enquanto Neruda se dedicava à construção do Canto General. O poeta foi convidado pelo PCB para participar da cerimônia de libertação de Carlos Prestes, num grande evento público ocorrido no estádio do Pacaembu, em São Paulo. A esta altura, Neruda era conhecido como poeta experimentalista, com fortes ecos surrealistas - assim já havia sido citado em nossa poesia formando o rol de preferência de Drummond, em "Consideração do Poema"31 - mas que depois de presenciar os absurdos da guerra iniciara sua conversão política e a adesão de sua obra à luta social.

Durante a primeira viagem pelo Brasil, Neruda é, num momento inicial, recebido e homenageado por Manuel Bandeira, na Academia Brasileira de Letras $\stackrel{32}{2}$. Dentro do partido comunista havia uma acirrada disputa entre Oswald de Andrade e Jorge Amado para decidir quem saudaria o poeta chileno diante da multidão de operários e militantes ansiosos pela noite apoteótica. Por motivos jamais aceitos por Oswald, Jorge Amado acabaria sendo o escolhido. O romancista baiano e Pablo Neruda iniciaram ali uma amizade de longa data ${ }^{\underline{33}}$. Neruda também travou contato com Prestes, o homenageado da noite, com Carlos Drummond de Andrade e outros importantes intelectuais ligados, naquele momento, ao partido comunista. Diante de 120 mil pessoas, ao lado de Jorge Amado e Nicolás Guillén, fez um eloquente discurso que, futuramente, graças a sua formulação lírica, seria reunido junto aos poemas do Canto General ${ }^{34}$.

Depois do evento oficial, descobre, em companhia do cicerone Vinícius de Moraes, a vida boêmia, as belezas e injustiças do Rio de Janeiro, também fundando uma amizade duradoura cujo interessante resultado literário pode ser visto no livro História Natural de Pablo Neruda: uma

31 "Neruda e sua gravata flamejante", diz o conhecido poema, na estrofe em que o sujeito enumera uma lista de autores ligados ao pensamento vanguardista, como Maiakovski e Apollinaire. (ANDRADE, 1987, p. 109)

32 Pouco tempo depois, quando o dogmatismo pecebista pulverizou de vez a já minguada simpatia de Manuel Bandeira pelo socialismo, o poeta do cacto relembraria a passagem na academia como um teatro patético. Curiosamente, é em uma entrevista ao amigo Thiago de Mello que ele rememora a passagem na Academia Brasileira de Letras: "Houve um tempo em que vi com bons olhos os comunistas. É que ainda não estava a par da política celerada deles. Por isso fui inocente útil. Coloquei meu nome em abaixo-assinado protestando contra violência da polícia. Fui convidado e aceitei saudar Pablo Neruda numa festa comunista. A pedido deles, levei Neruda e Nicolás Guillén à Academia Brasileira de Letras.” (BANDEIRA, 1952, p. 234)

33 Sobre este assunto, vale a leitura do artigo de Ariana Witkóvski (2004). A autora examina com profundidade os vínculos de amizade, criação e convicções políticas entre Neruda e Jorge amado.

34 Em Confieso que he Vivido, Neruda relembra com carinho do evento, dando-lhe uma exagerada importância para os rumos que sua poesia viria a seguir após aquele momento de busca intensa: ““Um poeta que lê seus versos diante de cento e trinta mil pessoas nunca mais será o mesmo nem pode escrever da mesma maneira depois dessa experiência” (NERUDA, 1977, p. 312). 
elegia que vem de longe (2006) que Vinícius escreve após a morte do amigo, em 1973. Nesta curiosa obra, o tom amargo e elegíaco decorrente da perda se mescla com as lembranças alegres das passagens vividas com Neruda. Para o nosso estudo, é importante observar que a apresentação da edição mais recente de História Natural de Pablo Neruda... é escrita por Ferreira Gullar. Neste breve texto, confirmamos uma das marcas do autor maranhense: a concisão é absoluta, o prefácio ao livro de Vinícius é objetivo, limpo, quase técnico, diríamos. Não se deixa entrever nenhum sentimento de fascínio por Neruda e mesmo em relação ao próprio Vinícius de Moraes - amigo próximo de Gullar e o grande responsável pela publicação do Poema Sujo (1976) no Brasil, enquanto o autor cumpria seu exílio no Chile - as palavras de estima são econômicas, sem nenhum alumbramento, nenhuma exaltação. Mais adiante, quando comentarmos o papel dos prefácios na obra de Thiago de Mello, sempre carregados de afetividade e embutidos na atmosfera solidária que fundamenta seus livros, o contrate com este pequeno texto de Gullar pode ser bastante esclarecedor.

Depois deste primeiro contato com alguns dos nossos escritores mais importantes, Neruda logo se converterá numa espécie de interlocutor do Brasil na América Latina. Diante da tênue e tensa relação entre Brasil e América Hispânica, já examinadas no primeiro capítulo, Neruda assumia para si a tarefa de preencher a lacuna enunciativa, tornando-se, por sua atuação literária e política, uma espécie de embaixador dos poetas brasileiros no Chile e nos outros países da América Latina nos quais sua obra circulava com semelhante êxito. O resultado é que vários de nossos autores passaram a ser mais conhecidos no continente - ainda que em círculos muito bem determinados -, e receberam diversos convites para eventos literários e políticos, ajudando a formar uma inédita onda de intercâmbios real entre poetas destes países. $\frac{35}{}$

Por outro lado, ao marcar terreno frente ao intrincado nacionalismo do PCB, Neruda desperta em nossos autores um interesse pelos poetas dos países vizinhos. Mesmo os grandes

$35 \mathrm{O}$ avanço pode ser medido pelos encontros de escritores, que se tornaram comuns naquele momento de intensa cobrança em relação ao papel social dos intelectuais. Eles atestam a importância de Neruda para uma circulação de repertórios entre o Brasil e os países hispano-americanos. O antológico congresso da ABDE (Associação Brasileira dos Escritores), realizado no Rio de Janeiro, em 1945, contava, dentre os convidados estrangeiros, com apenas dois latino-americanos (para se ter uma ideia, estavam presentes oito franceses). Neste congresso ficou marcada a posição dos intelectuais brasileiros em favor das liberdades democráticas, contra o Estado Novo getulista, representando um importante passo na história intelectual brasileira, no qual as posições examinadas no primeiro capítulo (dogmatismo partidário, autonomia crítica, torre de marfim) foram colocadas em intenso debate (LIMA, 2010, p. 12-18). Menos de uma década depois seria realizado em Goiânia o I Congresso da Cultura Brasileira, desdobramento indireto do grande encontro intelectual organizado no Chile, por Neruda e Gabriela Mistral. Sem ter, é claro, as mesmas proporções e importância histórica do encontro de 1945, chama atenção a inversão verificada na nacionalidade dos convidados: foram mais de 30 autores dos países vizinhos - doze apenas na comitiva que vinha do Chile, sob a batuta de Neruda, a estrela maior do evento (TEITELBOIM, 1996, p. 367-368). 
nomes das vanguardas latino-americanas do início do século XX - nos anos 1950 já completamente inseridos no cânone da literatura hispano-americana - só serão traduzidos para o nosso idioma nesta época e por autores ligados a este projeto: como se faz notar pelas rápidas traduções dos livros de Neruda para o português ou, por exemplo, a tradução da Poesia Completa de Cesar Vallejo (1985) feita por Thiago de Mello. Por fim, o próprio Neruda escolherá o jornal carioca $O$ cruzeiro para divulgar os primeiros excertos de suas memórias, que depois formariam o núcleo vivo de Confesso que vivi (1977).

É durante aquela breve, porém movimentada, viagem pelo Brasil que Pablo Neruda conhecerá Thiago de Mello. A esporádica conversa entre os dois num encontro fortuito na editora de Ênio Silveira se transformaria, poucos anos depois, em grande amizade e parceria intelectual das mais interessantes. Os dois retomam o contato quando Thiago assume o cargo de adido cultural do Brasil no Chile, momento em que estreitam os laços. Após o golpe militar brasileiro, o poeta amazonense é preso e, depois de libertado, retorna às pressas para cumprir parte de seu exílio no Chile. Durante este período, viverá em uma das casas de Neruda, tendo contato intenso com o autor e sua derradeira esposa, Matilde Urrutia. Nesta época, traduzirão as obras um do outro e escreverão, a quatro mãos, um livro de poemas, do qual foram distribuídas entre amigos algumas poucas cópias.

A admiração prévia e em seguida a convivência com Neruda terão lá sua importância nas mudanças que sofrem a poesia de Thiago de Mello nos anos 1960, embora o tortuoso assunto das influências literárias nos pareça, para esta discussão, menos interessante do que a transposição da celebridade de Neruda à condição de um recorrente personagem da literatura brasileira. Em outros termos, parece mais intensa a presença de Neruda como um tema, um personagem, do que propriamente como um "mestre" no sentido de difusão de um estilo.

No entanto, o crítico carioca José Guilherme Merquior, em coro com a polarização anteriormente mencionada, não concorda com este juízo e renegaria em bloco um grupo de poetas taxados pejorativamente de "nerudinhas" (MERQUIOR, 1960 apud CAMENITZKI, 2006, p. 38) , alcunha com a qual se referia jocosamente a Moacir Félix, Geir Campos e Thiago de Mello.

$\mathrm{O}$ teor severo das palavras de Merquior diz respeito à utilização de uma linguagem pomposa, do ritmo declamatório, farto de metáforas carregadas, além, é claro, da insistência ao anunciar, de forma muitas vezes maniqueista, inimigos mordazes e auroras invencíveis. Há também 
a encenação de uma comunhão com o povo, mistificado como instância suprema da luta social e o esforço em homogeneizar diferenças por meio de uma poesia laudatória, pregando sempre a união em torno de uma causa única, infalível. É preciso ter em conta que estas características, embora maciçamente reconhecidas pela crítica especializada na poesia de Neruda ${ }^{36}$, referem-se a uma parte relativamente curta da obra do poeta chileno - basicamente a uma parte de Canto General (1950) e Las Uvas y El Viento (1963) - e com algumas ressalvas poderíamos apontar expedientes semelhantes na obra dos brasileiros, sem que isso configure, a nosso ver, papel que justifique o rótulo criado pelo crítico carioca.

Interessante é perceber que Merquior poupa Gullar de suas críticas. Mais que isso, em artigo posterior, ele louva a obra do autor maranhense como exemplo de superação disto que, para ele, seria uma poesia piegas, simplista na forma e demagógica nas convicções. De acordo com o jovem Merquior e com a tradição crítica na qual está inserido, nem Neruda, muito menos seus seguidores, se disciplinavam para imprimir na forma de seus poemas o ímpeto libertário das causas que defendiam. Neruda era apresentado como um poeta de muito vigor e pouco rigor, já seus discípulos tupiniquins nem vigor tinham. Malgrado cantassem a mudança, permaneciam presos a uma poesia derramada, recalcitrando romantismos superados e perdendo seu poder possível de mobilização. Estamos diante de uma reformulação da conhecida máxima consagrada pelo poeta russo Maiakvoski: a de que não existe arte revolucionária sem forma revolucionária. Ou como o crítico João Luiz Lafetá defende ao pensar o modernismo brasileiro: “o projeto estético, que é a crítica da velha linguagem pela confrontação com uma nova linguagem, já contém em si o seu projeto ideológico possível” (LAFETÁ, 1974, p. 4). Observemos um trecho da argumentação de Merquior em favor da poesia de Gullar:

a sua surpreendente capacidade de liricizar, sem nunca estetizar o chulo e o banal, que lhe permite evitar a erva daninha da literatura engajada - o clichê ideológico. Se não pode dizer que o prosaísmo esteja de todo ausente dessas páginas, várias das quais não chegaram propriamente a uma solução rítmica adequada, vibra no conjunto uma virtude quase respiratória, uma direiteza visceral lembrando aqui e ali a grande voz de José Brodsky (...). Em vez do fácil clamor dos protestos genéricos, a consciência social de Gullar prefere dar a palavra às coisas, ao seu contido e compungido senso de lacrimae rerum. Um poeta participante que recusa tanto o slogan quanto a poesia digestiva, e destila com minúcia o sentido humano de suas lembranças. (MERQUIOR, 1990, p. 75)

36 Nesta crítica se destaca alguns textos consagrados, como os de Hernán Loyola (1997) e Alain Sicard (1981). 
Entretanto, a celeuma em torno de Pablo Neruda mostrava-se bem mais ampla e confusa no calor dos anos 1960. Outros intelectuais seguiram o caminho inverso ao de Merquior e não hesitaram em aproximar Ferreira Gullar de Neruda, lançando sobre ele o rótulo - ofensa mortal ou elogio sublime, dependendo do atacado e do atacante - de "Don Pablito Neruda do Brasil". Trata-se de Décio Pignatari, o “inimigo íntimo”, que em 2007 faz o seguinte comentário sobre Gullar: "Inicialmente até chegamos a trabalhar juntos. Mas, posteriormente, acho que o Gullar repensou: 'eu tenho condições de ser o Don Pablito Neruda do Brasil'. Então ele entrou para o Partidão" (PIGNATARI, 2007). Mais para reatiçar antigas polêmicas do que para uma análise poética mais séria, o ataque de Pignatari serve para mostrar como a recepção crítica de Neruda em nosso meio era contraditória (e ainda é, visto que o texto em questão, em que ela é resgatada, data de 2007) e baseada em preconceitos tanto contra como a favor do chileno.

Resta, pois, por trás das pontes tênues que a crítica lançou em torno de Neruda e Gullar, a bela tradução que o poeta maranhense faz para o delicioso e lúdico Livro das Perguntas (NERUDA, 2009), mostrando, tardiamente, que nem Neruda se limitava ao militante agressivo e retórico presente em alguns de seus livros, nem que o temperamento lírico de Gullar era o oposto preciso ou a cópia dócil do vate chileno.

O inquebrantável debate que tem a poesia de Neruda como um de seus vértices principais continua vivíssimo em nossos dias e está representado por Ferreira Gullar, que mesmo ao flertar com a poesia populista, com o cordel, não perdia de vista a constituição de uma obra inovadora, capaz de dar voz, no plano estético, ao desejo de renovação da ordem social. A luta contra a forma poética e ânsia pela expressão pessoal afastam drasticamente a poesia dos dois autores que escolhemos para estudar. Thiago de Mello chega a enunciar em seus poemas a reverência de sua obra ao plano instrumental da poesia; exalta frequentemente sua recusa aos padrões estetizantes da poesia vanguardista e confessa desprezo em relação à obsessiva procura de originalidade no plano da elaboração formal:

Nada criei de novo.

Nada acrescentei às formas

tradicionais do verso.

Quem sou eu para criar coisas novas,

pôr no verso, Deus me livre, uma

invenção.

(MELLO, 1996, p. 14) 
Taxada como sintoma de apatia, conservadorismo e até mesmo como ignorância literária, a "humildade" regularmente expressa pelo sujeito da poesia de Thiago de Mello nos parece muito mais interessante se analisada como elemento coerentemente ordenado na construção de um ethos que é o polo radiador de sua poética. A enunciada recusa ao experimentalismo está de acordo com o tom que o poeta amazonense imprime em sua obra, que é o da cumplicidade com o leitor, forjada com base na máxima ocultação da forma literária: ao anunciar suas auroras, a poesia de Thiago de Mello se despoja, às vezes de maneira um pouco desastrada, de sua própria dimensão estética: ela finca raízes no desejo de "comunicar-se" e acredita coerentemente que esta conquista só é possível às custas do mero "enfeitar-se". Assim, encontramos passagens instrutivas como a seguinte:

Ofereço arte poética?

Inauguro nova flor?

Não.

Entrego um rumo de amor.

(MELLO, 1996, p. 14)

No livro Poesia e política: a trajetória de Ferreira Gullar (2006), a autora Eleonora Ziller Camenietzki desenvolve uma breve reflexão comparativa entre Ferreira Gullar e Pablo Neruda. Ao assinalar a dimensão oposta dos dois escritores, ela chama com pertinência a atenção para o tom triunfalista da obra de Neruda, sempre segura da vitória final, a redenção do povo em torno de uma causa comunista, o que dá a sua poesia uma vocação para a palavra encantada, que se faz linguagem de exaltação e estímulo à luta, ao passo que em Gullar (ela está pensando basicamente no Poema Sujo) a rica inquietação da voz lírica não permite certezas inexoráveis, como também não se deixa tornar porta-voz de uma causa maior; ao contrário, faz com que o drama social surja por meio do choque do sujeito com a mais trivial realidade que o cerca.

Ele não abandona a consciência da forma literária e as contradições inerentes à expressão lírica para alcançar a comunicação com o leitor, mas faz da tensão entre sujeito x mundo o elo pelo qual se instiga no leitor um novo olhar sobre as práticas que o rodeia. Vale assinalar que esta distinção serve de guia para entendermos a gradativa inserção de Ferreira Gullar entre os principais autores de nosso tempo, bem como o relativo esquecimento da obra mais empenhada de Neruda nos dias de hoje e, mais ainda, o generalizado desprezo da academia pela poesia de Thiago de Mello. Após estabelecer semelhanças entre o Poema Sujo de Gullar e o Canto General de Neruda - como por exemplo a situação do exílio e a proximidade ideológica dos autores - Camenietzki reforça a distância entre as duas poéticas: 
O Poema Sujo, entretanto, não se resume à afirmação de qualquer programa político. Ao contrário, pode ser inserido numa perspectiva bastante crítica em relação à política da esquerda naqueles anos. Nenhum indício o faria crer que a vitória seria inexoravelmente alcançada, nem mesmo ele se sentia autorizado a falar das dores de todos os homens. Suas dúvidas não lhe permitiam sequer a confiança em que algo maior do que ele o sustentava, como ocorre em Canto General de Neruda.(CAMENIETZKI, 2006, p. 167)

Por outro lado, a semelhança entre a poesia de Pablo Neruda e Thiago de Mello, estaria na criação de uma aura de solidariedade entre o poeta e o leitor - facilmente desdobrável entre o vate e o povo, respectivamente - forjando a conclamação da união contra um inimigo figurativo e gerando uma obsessiva polaridade entre exploradores e explorados, algozes e vítimas e, exaustivamente repetidos na obra de Thiago, escuridão e luz, treva e aurora, tendo o canto como mediador entre a esperança e o triunfo final, ou seja, a própria utopia.

Esta ultima ideia está contida no título do livro Faz Escuro Mas Eu Canto (1966). A luz e sua ausência surgem como metáforas da vida social, da opressão e exploração (treva, escuridão, breu) e da utopia anunciada pelo poeta e inscrita na força solar do canto (luz, claridade, manhã, sol, alvorada). A constante repetição dos termos é um dos clichês mais execrados - e execráveis - de sua obra, mas no caso específico do título em questão, o jogo didático entre luz e sombra ganha um significado menos banal. Ali o "escuro" é menos evasivo, pois se refere mais concretamente à ditadura brasileira, sendo, portanto, uma sugestiva menção à privação de liberdade, e que se completa na rebeldia, na resistência: "mas eu canto". O canto emerge como o oposto preciso da escuridão, o canto é luz, desafio, claridade. A construção também é mais feliz pela escolha sintática inusitada: o verbo fazer exige um sujeito, por isso gera estranheza, pois sugere um agente externo, algo que a formulação indeterminada "Está escuro mas eu canto" não daria conta.

Faz escuro mas eu canto é o primeiro livro publicado por Thiago de Mello após o golpe militar brasileiro. Nele está minuciosamente marcada a adesão do poeta a uma causa libertária de fundo socialista. Há, inclusive, um capítulo no qual é encenada a conversão, com uma série de poemas que demonstram a tomada de consciência ("A vida verdadeira”, "39 anos de um cidadão brasileiro"). É a partir dele que ocorre a explosão da temática social que se tornaria marca registrada de sua poesia - comprometimento que antes era ocasional, velado, tímido. Por conta de tudo isso, não pode ser por acaso que o livro seja dedicado a Pablo Neruda e, também não por acaso, a América Latina é exaltada como um espaço de luta, destinado à liberdade. Eis a dedicatória do 
livro:

\author{
Para Pablo Neruda \\ - o meu Paulinho - \\ voz cristalina e ardente, que se ergue \\ cantando em cada amanhecer \\ a libertação de nossa América.
}

(MELLO, 1984, p. 208)

A pequena nota realça a intimidade entre o poeta e o ilustre homenageado, visível no epíteto carinhoso "meu Paulinho". Prefigura-se uma convivência prévia entre ambos, uma cumplicidade e mútuo respeito. A voz de Neruda retumba com seu canto libertário, cercado de luzes matutinas ("voz cristalina", "amanhecer"), erguido em nome da causa latino-americana. Portanto, nos poucos "versos" que compõem a dedicatória - pelo teor solidário da poesia de Thiago não podemos deixar de ler as suas singelas dedicatórias, apresentações e cólofons como partes integrantes da unidade lírica que rege seus livros - reunimos os três aspectos mais marcantes da representação de Pablo Neruda pelos poetas brasileiros: a imagem do companheiro leal, a militância libertária em prol da aproximação latino-americana e a grandeza da voz poética do chileno.

Neruda era o astro maior de uma luta mais ampla; sua poesia era tida como arma das mais poderosas e os poetas que com ele dialogavam, dentro da dinâmica de solidariedade, o saudavam como modelo maior a ser seguido, vide um trecho do "Soneto a Pablo Neruda", de Vinícius de Moraes:

E o seu amor - o amor que hoje encontramos...

Por isso, ao se tocarem nossos ramos

Celebro-te ainda além, Cantor Geral

Porque como eu, bicho pesado, voas

Mas mais alto e melhor do céu entoas

Teu furioso canto material!

(MORAES, 1967, p. 33)

Neruda é o "Cantor Geral" - em referência óbvia ao seu Canto General - aquele que voa mais alto e melhor, mas cujos laços fraternais não deixam de se prolongar por conta desse aparente desnível. O “canto maior" (no caso, o de Neruda) e o "canto menor" (assumido, com típica modéstia, por Vinícus) se enlaçam num só e tornam-se mais fortes por conta disso. Essa mesma perspectiva celebratória está presente em muitos poemas, depoimentos e trabalhos críticos de Thiago de Mello. 
No poema "A mão", por exemplo, a imagem de Neruda escrevendo seu famoso "Alturas de Machu Picchu" é comparada com os atos de escrita de Homero e Cervantes, ao elaborarem suas obras-primas. O poeta chileno é ali saudado como um clássico e seu poema já cultuado como obra destinada a ter para a América Latina o mesmo papel que uma Ilíada ou o Dom Quixote tiveram para sua respectivas culturas $\underline{37}$

Num outro poema de Thiago, "Tradução, verso e música”, o nome de Neruda aparece novamente com o viés da cumplicidade entre os escritores:

\author{
Mas já é de Neruda \\ poeticamente \\ dele \\ a manhã que eu juro que vi.
}

(MELLO, 1996, p. 82)

O poema fala sobre as artimanhas da tradução e no excerto mencionado comenta a sensação do poeta ao ter um de seus versos traduzidos pelo amigo chileno. Explora-se a ideia da tradução como transcriação, com a "manhã" contida no poema de Thiago sendo atribuída a Neruda, que assume a missão de reinventá-la para o espanhol.

Num último exemplo, temos o caminho inverso. É Neruda quem homenageia o parceiro com um soneto de circunstância. Cabe explicar que era prática comum do poeta chileno presentear os amigos com singelos sonetos, que não seriam publicados em sua obra, mas que serviam como regalos de ocasião. Além de Thiago, sabe-se que Vinícius de Moraes e Jorge Amado também receberam estes poemetos de Neruda. Na maioria dos casos, os próprios homenageados tratavam de publicar os sonetos em suas obras e é justaente na abertura de De uma vez por todas (1996) que vem à tona o interessantíssimo “Thiago y Santiago", inicialmente escrito no Chile em 1963:

\title{
(...)
}

Te perdonamos porque con tu bella

de rosa en rosa y de estrella em estrella, te llamará el Brasil a su desfile

37 A elevação de Neruda à condição de "poeta maior" não é, evidentemente, exclusividade dos autores brasileiros. Ao receber o prêmio Nobel de literatura, Gabriel García Marquez havia formulado em seu discurso uma sentença quase idêntica a que Thiago de Mello escreveria no poema "A mão", anos depois. Disse o escritor colombiano: "Ầ poesia que o velho Homero enumerou em sua Ilíada [...] à poesia que retém, no delgado andaime do tercetos de Dante, toda a fábrica densa e colossal da Idade Média. À poesia que com tão milagrosa totalidade resgata nossa América nas "Alturas de Macchu Picchu", de Pablo Neruda, o grande, o maior" (MARQUEZ, 2011, p. 30). O mesmo "Alturas de Macchu Picchu" é assinalado como obra-prima de Neruda, o mesmo conjunto de enumeração de autores clássicos, a mesma natural inserção do poeta chileno, ou mais explicitamente latino-americano, entre as obras mais representativas da cultura ocidental. 
Te irás, hermano, con la que elegistes, tendrás razón, pero estaremos tristes, que hará Santiago sin Thiago de Chile?

(MELLO, 1996, p. 5)

O poema fala da despedida de Thiago ao sair da casa de Neruda e retornar para o Brasil. O poeta brasileiro retornaria ao país após cumprir missão diplomática, mas, aqui chegando, seria preso e, pouco depois, voltaria ao Chile, agora na condição de exilado político. Em seu soneto, Neruda faz um trocadilho com o nome do amigo brasileiro e a capital chilena, além disso, lamenta a falta que o poeta e amigo faria em seu país, num melancólico pesar que, contudo, não deixa de reconhecer a importância do regresso sugerindo uma "missão" a ser cumprida pelo amigo em seu Brasil natal.

Há, claro, outras referências entre Pablo Neruda e Thiago de Mello, mas acreditamos que os exemplos mencionados são suficientes para esboçar o fecundo diálogo que eles travaram em suas obras bem como a importância de Neruda enquanto "cantor maior" da causa latino-americana e atuante interlocutor da poesia brasileira na América Hispânica durante a década de 1960. Talvez as circunstâncias políticas do momento até dispensassem a intermediação de um nome da envergadura quase mítica de Pablo Neruda para que o desejo de diálogo ganhasse ecos para além da "ilha Brasil", no entanto, não resta dúvida de que sem a popularidade de Neruda, tanto nos círculos intelectuais latino-americanos como dentro do Chile, parte deste trânsito de obras, ideias e autores seria menos produtivo e interessante.

\section{3- A Revolução Cubana e a poesia brasileira}

No decorrer dos anos 1960, a carga simbólica da Revolução Cubana ultrapassou todas as fronteiras imagináveis e se converteu no duradouro exemplo de luta armada vitoriosa na América Latina. Ela foi hasteada, sob o olhar de toda uma geração, como a prova viva de que o povo, convencido da justeza de uma causa, poderia se revoltar diante da opressão e erguer-se em triunfante revolta. Por isso:

Nenhuma revolução poderia ser mais bem projetada para atrair a esquerda do hemisfério ocidental e dos países desenvolvidos, no fim de uma década de 
conservadorismo global; ou para dar à estratégia da guerrilha melhor publicidade. A revolução cubana era tudo: romance, heroísmo nas montanhas, ex-líderes estudantis com a desprendida generosidade de sal juventude - os mais velhos mal tinham passado dos trinta -, um povo exultante, num paraíso turístico tropical pulsando com os ritmos da rumba. E o que era mais: podia ser saudada por toda a esquerda revolucionária. (HOBSBAWM, 2010, p. 427).

Multiplicava-se, de livro em livro, de discurso em discurso, o êxtase de se ver surgir em uma pequena ilha, a poucos quilômetros da maior potência capitalista do mundo, um levante de grandes proporções que mudaria os rumos políticos da América Latina, apimentando a tensa dualidade entre o modelo norte-americano e a opção socialista. A esse desenlace de base política se misturava formulações culturais carregadas de simpatia pelo grupo de jovens barbudos e idealistas capazes de animar as forças populares, derrubar um governo ditatorial e lançar Cuba na projeção das grandes nações soberanas, auto denominada a própria ilha da utopia em construção. Vale reforçar tais ideias com as justas palavras de Ángel Rama, para quem a Revolução Cubana:

Es, obviamente, un hecho político-social, pero sería miopía ignorar la recepción de tales hechos en el mundo del espíritu - en la realidad civilizadora - y sería desconsideración y error creer a nuestros intelectuales tan desprendidos de la realidad histórica para que un fenômeno que ha puesto en América toda una ascua renovadora, no los afectara hondamente (...) La revolución no ha venido a traer paz, sino guerra, y ha servido de imprevista montaña que separó las aguas en sentidos distintos y opuestos ${ }^{*}$. (RAMA, 2006, p. 49)

A luta liderada por Fidel Castro assumia a missão de provar que era possível derrotar o gigantesco inimigo e sua aparência de invencível para cravar no continente as calejadas promessas de justiça social, reforma agrária, ampliação dos serviços sociais e, como a revolução mostrou depois de assumir o poder, a própria adoção do socialismo. De simples rebelião guerrilheira localizada, a luta armada foi realçada com contornos heroicos e o clamor que se espalhava pela esquerda latino-americana era o de que nenhum país negligenciasse a lição da Sierra Maestra garantindo, como num espontâneo e irresistível efeito dominó, que aquela luta se espalhasse por todos os países contagiando o continente inteiro:

Mas se você é honrado, não deve se conformar.

\footnotetext{
* É, obviamente, um feito político-social, mas seria miopia ignorar a recepção de tais feitos no mundo do espírito na realidade civilizadora - e seria ignorância e erro crer em nossos intelectuais mais desprendidos da realidade histórica para que um fenômeno que espalhou por toda América uma ânsia renovadora não os afetasse profundamente (...) A revolução não veio trazer a paz, e sim a guerra, e acabou servindo de imprevista montanha que separou as águas em sentidos distintos e opostos.
} 
Ponha a prancheta de lado

e venha colaborar.

O povo pobre cansou da fome

que o dólar vem aumentar

e vai sair para a luta

que Cuba soube ensinar.

(apud HOLLANDA, 2004, p. 29)

O fragmento do poema citado foi escrito por Oscar Niemeyer, publicado na Violão de Rua, a já mencionada revista do CPC, e faz uma convocação aos seus colegas arquitetos pedindo que superem o conformismo burguês e se irmanem à luta popular, seguindo à risca a lição cubana. Com mensagem idêntica, e mesma forma simplória e simplista, multiplicavam-se pelos quatro cantos da América poemas, artigos, livros, pinturas e canções que homenageavam a ousadia revolucionária e pintavam o quadro antológico dos libertadores ovacionados pela multidão de cubanos, entusiasmada pelo atrevimento de inaugurar um regime peculiar, que mais de 50 anos depois permanece gerando calorosos debates e controvérsias nos dias de hoje. Citando novamente Ángel Rama, recuperamos algumas das impactantes consequências de Cuba para a discussão da identidade intelectual na América Latina, do movimento de politização da literatura e o novo espaço do escritor nesta sociedade:

Se han radicalizado las posiciones y al mismo tiempo se ha producido un deslizamiento hasta la izquierda.(...) Podría argumentarse que la Revolución cubana, el gobierno nacional, han provocado una toma de posición en lo que un escritor tiene de ciudadano y no en su específica cualidad de intelectual artista. No es así: si consideramos a la Revolución cubana el hecho cultural, es porque creemos discenir una remoción ideológica y psicológica de grandes proyecciones para la vida intelectual del país ${ }^{*}$. (RAMA, 2006, p. 50)

A inspiração que chegava de Havana era a da rebeldia, da necessidade de se construir a história; seu triunfo soava como a prova definitiva e irrefutável de que a luta dos mais sofridos alcançaria a mesma glória com que os cubanos marchavam para a sua capital. Tanto que no início dos anos 1990, já após a derrocada da URSS, Ferreira Gullar relembrava o impacto da notícia:

Eu estava de plantão naquela noite de 31 de dezembro de 1958, na redação do diário de notícias, quando a notícia chegou: Batista tinha fugido às pressas, a revolução cubana estava vitoriosa. Eu não era ainda um militante de esquerda, mas odiava Batista e simpatizava com aquele grupo de jovens revolucionários que se

\footnotetext{
* As posições se radicalizavam e, ao mesmo tempo, se produzia um deslocamento para a esquerda. Poderia se argumentar que a Revolução cubana, o governo nacional, provocaram uma tomada de posição naquilo que o escritor tem de cidadão e não em sua qualidade específica de intelectual artista. Não é assim: se considerarmos a Revolução cubana um fato cultural, é porque imaginamos discernir um impacto ideológico e psicológico de grandes proporções para para a vida intelectual do país.
} 
sublevara contra a ditadura. As notícias iam chegando e compondo aquele quadro extraordinário na vida dos povos latino-americanos. (GULLAR, 1992, p. 48)

Assim como Gullar, parte graúda da militância do período ampliava o campo de visão e via não apenas a vitória de um grupo ou de um país, mas o triunfo do continente inteiro, destinado a seguir o caminho inaugurado pelos cubanos. A data oficial da Revolução Cubana seria $1^{a}$ de janeiro de 1959, dia em que o ditador Fulgêncio Batista foge do país e os guerrilheiros assumem o poder. Entretanto, o marco que transformaria a Revolução Cubana de um fato político a um evento cultural sem precedentes na América Latina seria o rompimento das relações com os EUA e a oficialização da República Popular de Cuba, logo seguida pela adesão ao bloco socialista, isso já em meados de 1961.

Como fermento deste percurso que vai da vitória militar, em 1959, à entrada no bloco socialista, estão os conhecidos e inflamados discursos de Ernesto Che Guevara - que será uma espécie de símbolo do inconformismo e da entrega própria da revolução. De combatente virtuoso, Guevara passa a ser, nos primeiros meses após a vitória, um tipo peculiar de embaixador informal da Cuba revolucionária, falando em nome do país diante da ONU e do bloco socialista, com o qual Cuba começava a dialogar. Sua postura torna-se gradativamente mais radical e agressiva, com críticas duras ao capitalismo e ao imperialismo norte-americano, incentivando novos focos guerrilheiros e divulgando publicamente a solidariedade de Cuba para com as lutas nos países latino-americanos e na África.

É neste período - que Florestan Fernandes chega a chamar de "revolução dentro da revolução" (FERNANDES, 1979, p. 69) - de adesão ao bloco socialista que teremos uma investida na situação política de Cuba por parte dos intelectuais de esquerda, acompanhada por uma revalorização da revolta armada, dos anos de luta guerrilheira até a tomada do poder. Importante lembrar que durante o período de combates contra o exército de Batista o caminho do socialismo não era tão óbvio para os insurgentes. O próprio governo norte-americano preferiu não investir militarmente na resistência do governo aliado - para alguns menosprezando a força dos rebeldes, para outros concluindo que, mesmo vitoriosa, os liderados de Fidel Castro não conseguiriam implementar mudanças na aparentemente sólida organização do estado cubano.

Até então a economia da ilha era totalmente dependente dos EUA, que possuíam (e ainda possuem) base militar em território cubano. La Havana era o famoso local local onde soldados e 
magnatas norte-americanos iam se divertir com jogos de azar e prostituição; com seus cassinos e armazéns humanos que ficaram cinematograficamente registrados no clássico filme soviético Soy Cuba. Somente após consolidarem um governo revolucionário é que as tensões entre EUA e o novo governo cubano mostraram suas reais dimensões, quando as promessas de mudanças radicais começavam a ser postas em prática.

É, portanto, no início de 1962 que assistimos a um boom da Revolução Cubana pelos mais diferentes campos das artes e nos mais diferentes lugares. Mesmo os que negavam o caminho da luta armada, como era o caso de Ferreira Gullar, não deixavam de admirar a eficácia política daqueles jovens que não só implementavam um governo socialista com ampla base popular, como o faziam nas condições mais delicadas que se podia imaginar, dada a proximidade geográfica e a dependência econômica frente aos EUA. Da mesma maneira, alguns anos mais tarde, quando os movimentos ligados à contracultura, que deram o tom das agitações de 1968, atuavam com base em críticas severas tanto ao capitalismo como ao marxismo ortodoxo, a fotografia do marxista Che Guevara serviria de lábaro às grandes manifestações; nelas a Revolução Cubana, mais que exemplo político ou ideológico, era retomada em toda sua dimensão simbólica, festiva e utópica.

No caso do Brasil, como já vimos, as transformações em Cuba colocavam em xeque a ênfase que a esquerda do país dava ao nacionalismo e à política de alianças com a burguesia, que eram então desenvolvidas com base em orientações do PCUS e compartilhada por vários dos partidos comunistas latino-americanos. Ao lado da análise das especificidades do país e no posicionamento diante de sua etapa histórica de desenvolvimento, os militantes começavam, a partir da notícia estrondosa da revolução, a chamar atenção para as articulações supranacionais, ativando identidades atrofiadas e estabelecendo novos canais de comunicação entre os países.

Sofrendo os efeitos da experiência cubana, o cenário da esquerda brasileira se dinamiza: ganham força, dentro e fora do partido, os grupos que defendiam a luta armada e que iriam desembocar nas chamadas guerrilhas romântica dos anos 1970 (algumas com treinamento e subfinanciamento cubano) e as articulações entre os países latinos passam a ser propostas com mais frequência, principalmente no âmbito da circulação cultural. A poesia, e as artes em geral $\frac{38}{\text {, surge }}$ como canal para se pensar as semelhanças entre os países, forjando acontecimentos, descrevendo

38 Uma boa parte do cinema de Glauber Rocha, por exemplo, é marcado pelos vários anos em que morou em Cuba. Na ilha caribenha filmou alguns de seus filmes, organizou outros e dialogou profundamente com os principais expoentes do cinema cubano. 
cenários e heróis, assumindo, assim, a missão de impulsionar o debate político.

Lembremos também que o governo cubano, àquela altura, estava convicto de que a sobrevivência econômica do país dependia da quebra de seu isolamento dentro da América Latina ${ }^{39}$. Era interesse estratégico do regime semear tanto a luta de grupos revolucionários, armados ou não, como a cumplicidade de grandes intelectuais, que dariam fôlego para o governo revolucionário diante da opinião internacional. Para o estreitamento dos laços entre a ilha e os demais países latino-americanos foi criada a Casa de las Américas. O órgão era, e ainda é, responsável pela política cultural cubana e fomentou, principalmente em seu auge nos anos 1970, o intercâmbio entre artistas e pensadores do continente, financiando publicações, traduções, viagens, concertos coletivos, dentre outras atividades menos nobres, como o filtro ideológico da arte cubana. Desse modo, o papel da Revolução Cubana na tendência comunitarista surge não apenas por conta de uma inspiração, de um exemplo a ser seguido, mas é também estimulada como parte estratégica para a consolidação do socialismo em Cuba e sua dispersão pelo continente: trata-se, do ponto de vista cubano, de um programa de governo.

Desse modo, quando trazemos esta discussão para o campo literário, não poderíamos deixar de ver nas obras do período um grande fascínio pela experiência lograda no país caribenho. Como bem ilustra o poema de Niemeyer, os autores engajados chamavam atenção para o ensinamento contido na vitória dos guerrilheiros e a potencialidade daquela mesma vitória se repetir no Brasil. Era preciso aprender com Cuba para que o país seguisse o mesmo caminho (ou caminho semelhante): o da revolta popular, das reformas sociais e do socialismo.

Na trajetória de Ferreira Gullar, o início dos anos 1960, como já vimos, corresponde a um momento de esgotamento e frustração com o debate vanguardista - cujo refinamento teórico e a radicalização formal geravam a sensação de esterilidade e incompreensão diante do público. Fatigado pelo debate das vanguardas tardias, o autor se volta para o outro extremo e almeja, nessa nova etapa, uma participação coletiva de alcance amplo. É uma fase em que a criação conjunta dá o tom de sua atuação artística, primeiro com o CPC, do qual seria presidente e um dos principais expoentes, e, após o golpe militar, à frente do teatro Opinião, ao lado de Vianinha.

39 A história recente do país caribenho mostrou que, à duras custas, Cuba conseguiu sobreviver ao isolamento e a derrocada da União Soviética, seu grande parceiro econômico. No entanto, após um período de miséria generalizada, os cubanos presenciaram uma relativa melhora graças, outra vez, a articulação com os países da nova esquerda latino-americana, sobretudo no projeto da Alba e nos acordos bilaterais com a Venezuela, Bolívia, Equador e o próprio Brasil. 
Com o golpe militar brasileiro, ruíam temporariamente as esperanças de reformas de base ensaiadas pelo governo João Goulart. Surgia, então, a emergência de, primeiramente, se derrotar a ditadura para, depois, retomar as aspirações que estavam tão vivas antes de 1964. No mesmo dia da tomada do poder pelos militares, Gullar decide efetivar sua filiação ao partido comunista e participar de qualquer forma da resistência ao golpe. Apesar de estar próximo aos dirigentes do "partidão" desde os tempos de CPC, Gullar acaba optando por oficializar sua filiação no pior momento possível, quando o partido, após um período de crescimento expressivo, voltava a operar na clandestinidade.

É um momento de escassa produção poética. Sua expressão em versos passara pela crise encenada em A Luta Corporal e buscara, sem sucesso, saídas no conceitualismo vanguardista e, depois, no engajamento didático, que era muito menos uma busca de expressão que delimitasse uma "fase" poética do que o desejo de auxiliar, por meio da sua atividade de escritor, na luta social. Perplexo, descobria que a experiência do neoconcretismo - cujo resultado mais ambicioso fora o "poema enterrado" $\underline{40}$ - o havia levado para o domínio das artes plásticas e não mais da linguagem literária, enquanto que nos Romances de Cordel havia se despojado de todo trabalho estético, portanto de suas inquietações mais profundas, para gerar uma poesia mais "acessível” para as massas trabalhadoras. Na vanguarda, Gullar alcançara a máxima incomunicabilidade com o público, pois mesmo as camadas letradas dificilmente apanhariam todas as nuances teóricas, conceituais e estéticas que incendiavam a rixa entre concretistas e neoconcretistas. Nos versos de cordel e no teatro "realista", entretanto, o poeta sacrificaria a pesquisa formal em nome da comunicabilidade, mas não só se frustrava com a falta de interesse do "público alvo" como também adquiria a consciência de que negligenciava o desenvolvimento artístico de seu temperamento lírico e das suas potencialidades criativas.

A superação deste impasse só começa a ganhar forma a partir dos debates que o grupo Opinião desenvolvia a respeito do trabalho artístico e do fim político ao qual se prestava. Neste grupo, surgido como resistência à ditadura, estavam, além de Gullar e sua esposa Thereza Aragão,

40 Trata-se de um dos pontos limites da experiência neoconcreta. Após apresentar sua série de "não-objetos", Gullar utiliza a casa do pai de Hélio Oiticica para construir uma sala de $2 \times 2$ metros, abaixo do nível do solo e, dentro dela, distribui vários cubos menores empilhados, cada um de uma cor e tamanhos diferentes, ao fundo do último deles estava escrito a palavra "Rejuvenesça". Seria, conforme relata ironicamente o autor, o primeiro poema da literatura mundial com endereço definido. Após esta experiência, destruída após uma chuva torrencial, Gullar dá como encerrada sua aventura pelo neoconcretismo, pois, ele relata, já havia ultrapasso os limites da poesia e penetrado, sem perceber e sem desejar, nos domínios das artes plásticas. 
Vianinha, Armando Costa, Pichin Pla e outros, sem contar a participação de Nara Leão, Zé Kéti e João do Vale no importantíssimo show "Opinião", que inaugurou o front cultural de oposição à ditadura $^{41}$. É com a peça Se correr o Bicho, se ficar o Bicho come, de 1965, que Gullar e Vianinha se reconciliam com o sentido estético mais elaborado sem, com isso, abrir mão da essência crítica de suas obras. Por isso, pode-se dizer que:

\begin{abstract}
é com o teatro Opinião que Gullar e seus parceiros reconhecem a lição aprendida com o CPC: não basta simplificar a obra de arte, querer introduzir conteúdos políticos para que ela seja facilmente compreendida pelo povo. No teatro Opinião, os temas políticos da atualidade continuavam subindo ao palco, mas, agora, com um acabamento formal requintado. Em cena, a luta contra a ditadura, mas com qualidade dramatúrgica. A obra de arte engajada pode (e deve) ter qualidade estética. (MOURA, 2001, p. 77)
\end{abstract}

Com este novo sentido para sua atuação intelectual, Ferreira Gullar voltava a dedicar-se com mais afinco à poesia. Seu livro seguinte só seria publicado quase uma década depois, quando cumpria parte do seu exílio por países da América Latina, como Chile, Argentina e Peru, além de um período na União Soviética. É com Dentro da Noite Veloz (1975) que, como defende a maioria dos seus críticos $\frac{42}{}$, se dá o início da fase madura de Gullar, na qual predomina, de acordo com Alfredo Bosi, uma estética que poderia ser sintetizada como "memorialismo engajado" (BOSI, 2008, p. 213). Neste livro já está determinado o caminho da superação do nacionalismo, efetivado na definição de tipos brasileiros (o camponês nordestino, o malandro carioca, o operário explorado, típicos dos seus romances em cordéis) e a abertura política para um olhar mais amplo, trazendo para o discurso poético, por exemplo, o fascínio pela Revolução Cubana.

Com base nesta linha internalizada na própria ordenação do livro, podemos compreender as características mais contundentes desta nova linguagem de contestação e o impacto da luta cubana enquanto estímulo material para o esforço americanista na produção do poeta maranhense. Vejamos como estas questões ganham forma poética em um dos poemas do livro:

\title{
Cantada
}

Você é mais bonita que uma bola prateada de papel de cigarro

Você é mais bonita que uma poça dágua

límpida

num lugar escondido

Você é mais bonita que uma zebra

que um filhote de onça

41 Ver HOLLANDA (2004, p. 35-39) e SCHWARZ (1978, p. 80-84).

42 LAFETÁ (2007a, p. 214 ), BOSI (2008, p. 211), VILLAÇA (1984, p. 68), CAMENIETZKI (2006, p. 54) 


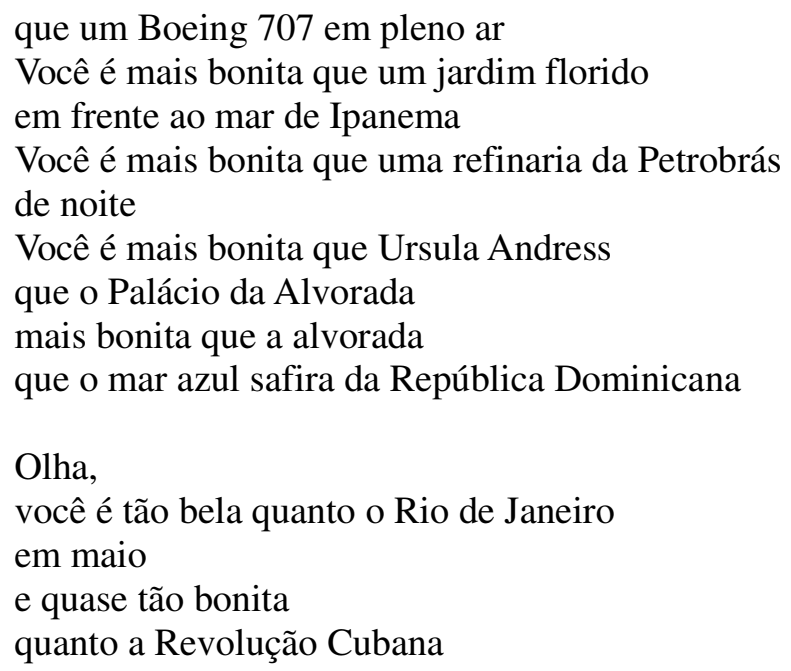

Este poema de Ferreira Gullar pode ser lido como uma paródia dos clichês da lírica amorosa. O título, "Cantada", surge como variação coloquial e despojada de variantes mais nobres como "canto", "canção", comumente visitadas como modo elevado e solene de se declarar à mulher amada. O poema subverte os lugares-comuns sentimentalistas e bajuladores presentes em boa parte da lírica amorosa de cunho romântico ou que dela deriva. Isso ocorre pois há uma quebra da visão idealizada da mulher, oferecendo uma abordagem altamente realista e irônica na declaração de amor. É neste jogo intertextual de superação e subversão de expectativas do leitor que reside a lógica, a crítica e até um leve roçar de humor neste poema de Gullar.

Nota-se que a carga emotiva perde seu fundo romântico conforme a cadeia de comparações se estabelece: ao invés dos termos sublimes, de imagens nobres e plasticamente rebuscadas para darem a dimensão da beleza da mulher para quem se declara, o poema tece aproximações inusitadas, símiles com base em elementos do cotidiano, marcados pela banalidade, por serem corriqueiros e prosaicos.

A marca desta etapa da poesia de Gullar, correspondente ao estilo alcançado na chamada maturidade lírica do autor, pode ser notada neste mergulho em objetos do dia a dia a fim de ressinificá-los poeticamente. O verso livre, permeado de aliterações, paranomásias e rimas ocasionais gera um efeito iluminador sobre esta poesia das coisas; e é a partir das "coisas" que as ideias políticas, a angústia do sujeito, sua revolta, a denúncia da injustiça e da exploração ganham estatuto poético: "a visão que se tem não é triunfalista nem dogmática. A má positividade é afastada por um movimento de autorreflexão, que está constantemente colocando o poeta frente a si mesmo" 
(LAFETÁ, 2007, p. 203).

O poema em questão quebra logo de início a expectativa do leitor ao romper com as imagens da tradição, em prol da valorização do insólito, do antipoético. Comparar o ser desejado com um papel de cigarro amassado, com uma poça de água ou com uma refinaria da Petrobrás é a maneira do autor firmar uma visão literária, ou mesmo uma poética, concentrada nos resíduos diários do "tempo presente" $\underline{43}$. O efeito das comparações pouco usuais gera uma reconfiguração dos juízos sobre os objetos mencionados. Isto é, para que a situação declaratória do poema se mantenha válida, é preciso que o leitor reflita a respeito dos termos selecionados. Em outras palavras, o jogo enunciativo gera uma tensão entre o conteúdo e a forma como ele é apresentado: ou a musa é banal e prosaica como as imagens com as quais é confrontada, ou de fato há nestes elementos do cotidiano uma beleza que a aproxima da musa, beleza esta ofuscada pela pressa da vida moderna e reconfigurada no poema que lhe lança uma luz nova, reveladora. A leitura mais válida parece ser a que indica que o inusitado das comparações deixa implícito que tais objetos tenham alguma beleza, ainda que secreta aos olhos mecânicos com os quais são comumente trespassados, e que ser "mais bela" que o papel de cigarro têm lá seu mérito e graciosidade. Aproveitando a imagem presente neste verso, lembramos que outro ponto muito comentado na poesia de Gullar é a ênfase nos detalhes plásticos - a textura (amassada) e a cor (prateada) - remetem à visualidade que o Gullar crítico de arte empresta aos seus poemas.

Há, portanto, um convite para que o leitor encontre, nas pequenas ninharias diárias uma beleza que tem sido milenarmente ignorada pelos poemas de amor. Algo semelhante pode ser dito sobre as comparações menos corriqueiras, como o filhote de onça - imagem da natureza, mas também símbolo da agressividade e da destreza -, o Boeing 707 - com sua beleza metálica e artificial, representando, talvez, a inteligência humana e se pretendendo índice da modernidade - ou a praia da República Dominicana, talvez a única imagem plenamente idílica do poema, que, ao lado do Rio de Janeiro, são os cenários diurnos, ambos latino-americanos, valorizados enquanto dignos de contemplação.

Nos versos finais, porém, o radicalismo das comparações começa a ofuscar a musa, gerando, assim, o ápice da paródia amorosa e a surpresa algo anedótica contida em seu desfecho. A cada comparação, a mulher desejada torna-se menos absoluta. Ao celebrar a musa, quem se declara é Dentro da noite veloz: "A poesia é o presente". 
uma voz racional e lúcida, que em nada se confunde com os suspiros exaltados dos tradicionais sujeitos enamorados. É dentro desse despojamento que o poema assume uma carga política mais forte, crescente, ao passo que a superioridade da mulher desejada é, na hierarquia do poema, regressiva. Só no verso final percebemos se tratar de um poema político e não de uma lírica amorosa. O expediente é significativo para compreendermos a obra do autor: a partir de Dentro da Noite Veloz o lugar do engajamento na poesia de Gullar não é mais de superfície, programático, mas nasce como consequência de uma visão de mundo, como olhar de um sujeito, vertigem e resíduos de um mundo em constante deterioração.

Na última estrofe, temos a quebra definitiva do tom bajulatório das comparações; do inusitado ao projectivo, o poema faz emergir a limitação da beleza da musa. A repetição da fórmula “você é mais bonita que..." é a tônica do primeiro segmento do poema, mas dá lugar, no desfecho, a uma sentença de igualdade inserida por um marcador próprio da oralidade: "Olha, você é tão bonita quanto o Rio de Janeiro em maio" e, por fim, não consegue alcançar a beleza de um fato, ou melhor, de um projeto político e a utopia que ele encerra: a mulher não poderia ser senão "quase tão bonita quanto a Revolução Cubana".

O desfecho irônico crava, de maneira simpática e original, o seu centro irradiador de sentidos: no fim das contas, dentro do sistema comparativo de "Cantada", é a Revolução, e não a mulher desejada, que ocupa o lugar mais destacado. Não obstante - e talvez aqui resida sua força expressiva - tal destaque à causa política é apenas parcial e não deformador; não há na lógica interna do poema nenhuma contradição, muito ao contrário, é de se aceitar que a formulação "você é quase tão bonita quanto a Revolução Cubana" seja, de fato, um elogio - ainda que surpreendente pela tradição amorosa com a qual o poema dialoga e, problematicamente, adere. A mulher a quem o poema é dirigido não sai de cena humilhada, ferida por não ser "a mais bela", ao contrário, deveria, quem sabe, sair, pela coesão da voz lírica, satisfeita de quase se igualar à beleza suprema de uma causa.

Thiago de Mello terá também um duradouro fascínio pela Revolução Cubana, devidamente registrado em verso. O poema "Segunda Declaración de amor" (MELLO, 1996, p. 148-149) atualiza a simpatia do poeta pelo governo de Fidel Castro, simpatia esta já apresentada em Poesia Comprometida... No poema, Cuba é apresentada a partir da fala de uma repórter que apresenta, televisivamente, a miséria e a opressão do povo cubano. Ao sujeito lírico, cabe o contra-discurso, a 
defesa do regime, a argumentação hipotética contra a moça que é descrita como portando um "sorriso demoníaco" por demonstrar um prazer incontido ao noticiar as mazelas do país caribenho. Se o poema de Gullar testemunha a euforia militante sentida nos momentos após a revolução, o de Thiago de Mello se dedica ao período de normalização do regime, sobretudo o de maior dificuldade, nos anos 1990, após o fim dos auxílios soviéticos.

O poema é um exemplo do que há de menos relevante na poesia de Thiago de Mello. Talvez sirva para ilustrar a faceta menos interessante de sua produção e os equívocos mais enrustidos em seu canto. Sem apresentar uma consistência poética, o autor recorta dois discursos cristalizados que se opõe, estaticamente: o da mídia capitalista, com seus evidentes preconceitos e ranços raivosos em relação a Cuba, e a do militante passional deslumbrado pelo regime. Não há nenhuma confrontação entre essas duas visões, nenhum olhar novo que supere o eterno papo de botequim, com argumentos previsíveis, que se tornou os colóquios sobre Cuba. O prosaísmo é latente no poema: se não fosse escrito em versos, ninguém farejaria qualquer indício de lirismo no texto, que na primeira parte apresenta a voz da repórter, por sua vez metonímia da "imprensa universal":

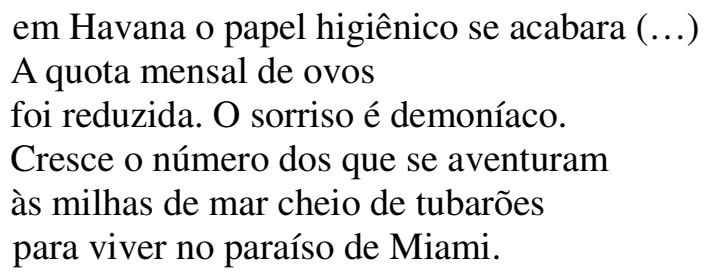

Segue-se à acusação da falácia tendenciosa da imprensa, a defesa banal, tão ingênua e frágil como a fala da repórter, do regime por parte do sujeito lírico:

Palavra alguma sobre o mal de chaga.

O embargo econômico mais perverso, a cada instante mais aperfeiçoado contra a vida, a vida, dos cubanos.(...) A moça diz, quase um raspão, que em matéria de saúde e educação Cuba até que deu alguns bons passos. Passos?

A medicina nuclear cubana, inventa, fareja, descobre (enquanto nós ainda estamos no chinelo).

Os argumentos são conhecidos de todos: as conquistas sociais cubanas, as dificuldades diante do embargue econômico. Certamente são pontos imprescindíveis para qualquer análise do 
papel de Cuba no cenário atual, de suas conquistas e erros, mas transcritos sem nenhuma mediação criativa para o discurso poético, os tópicos histórico-sociais perdem qualquer potencial literário ou, se é essa a intenção do poeta, deixam de ser persuasivos pela fixidez das posições apresentadas. $\mathrm{O}$ desfecho busca um caminho de síntese, modesta porém partidária. O sujeito diz que "Cuba está longe de ser uma sociedade perfeita", mas não abandona o uso indiscriminado do clichê ideológico:

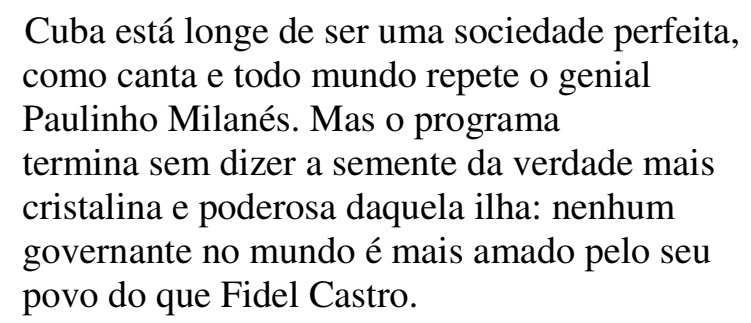

A exposição destes olhares sobre Cuba, no poema de Thiago de Mello, não provoca, não surpreende, não abala as convicções do leitor, perdendo com isso seu efeito estético, núcleo fundante de todo texto literário. Tentando não aderir a uma tradição de poemas de exaltação retórica da Revolução Cubana - poemas em tom maior, elevando heróis e mitificando os episódios e os combates - o poeta não alcança sua intenção aparente que é a de ser um balanço do socialismo cubano nos dias atuais. Recaindo na derramada apologia ao "governante no mundo mais amado pelo seu povo", o poema perde seu potencial crítico, misturando-se à banalidade dos argumentos superficialmente apresentados.

\section{4- Dentro da noite americana}

Para examinarmos a importância de Ernesto Che Guevara na circulação de um certo ideal de América Latina unida em voga nas décadas de 1960 e 1970, tal como apresentado até aqui, seria pouco o evocarmos apenas enquanto um dos personagens mais contundentes da Revolução Cubana. O fascínio que envolve o líder guerrilheiro ultrapassou todos os limites da luta que o consagrou e o colocou em posição destacada na política global. A ousadia dos discursos, a defesa apaixonada e muitas vezes impactante de seus ideais, aliado ao ilustre papel que ocuparia no desenvolvimento do socialismo em Cuba, explicam apenas a respeitosa admiração que recebeu em vida, mas não são suficientes para decifrar a atualidade do mito no qual se converteu. 
Se falarmos de alguns valores como a entrega, a impavidez sem limites, o espírito voluntarioso, o sacrifício, o martírio, a firmeza de caráter, valores transgressores de contestação radical ao status quo que são facilmente atribuídos ao mítico Che Guevara, começamos a entender por que sua história continua despertando vivo interesse em nossa época. Interesse que o leva a ser constantemente revisitado pelo cinema, pelas artes plásticas e pela música popular ${ }^{44}$, bem como a ser alvo de várias biografias - que vão de capas de revistas historigráficas e pseudo-historiográficas, abundantes em qualquer banca de jornal, à histórias em quadrinhos - e a força impressionante que ainda mantém aquele famoso retrato, tirado por Alberto Korda, ainda hoje um dos mais - senão o mais - reproduzidos do mundo, seja em flâmulas exibidas em greves e protestos ou em roupa de banho de grife sofisticada.

O poema "Dentro da Noite Veloz" (GULLAR, 2009, p. 195-202) dá nome ao livro que Ferreira Gullar publica em 1975 com poemas escritos durante a década anterior. Este belo exemplo da produção lírica de Gullar, corresponde a uma especulação sobre o estar no mundo a partir do embate com a imagem de Che, questionando os motivos que o levaram da prestigiosa posição que ocupava na política oficial cubana para a trágica aventura revolucionária na selva da Bolívia. É este poema que nos dedicamos a ler com mais atenção nas próximas páginas.

Em "Dentro da noite Veloz" o escritor novamente rejeita o tom pomposo da homenagem para expressar, mais que a admiração pelo destemido guerrilheiro, a consternação diante da luta aparentemente perdida, as esperanças abaladas pelo fracasso e a ânsia humana de progredir na aventura libertária ali levada aos seus limites. A subjetividade lírica se indaga diante do corpo mortalmente humano de Guevara, exposto como troféu de guerra na pequena escola de La Higuera $\underline{45}$, e o confuso desejo de perpetuar a revolta contida na fatídica noite de 8 outubro, quando houve o último tiroteio entre os rebeldes e os soldados e onde, de alguma forma, o poema apresenta como instante em que se decidia o futuro do continente. A voz lírica permanece solidária a Guevara, mas

44 As aventuras do jovem Guevara pela América Latina, convertida em parábola de formação no filme Diários de Motocicleta, de Walter Salles, ou o viés épico da trilogia Che, Steven Soderbergh, são exemplos das últimas retomadas de Che Guevara pelo cinema de grande alcance, sem contar documentários e as diversas produções de caráter regional. Nas artes plásticas citamos apenas os contundentes e badalados trabalhos de Andy Warrol. Na música, as canções de Sílvio Rodriguez, como a empolgada "Hasta siempre, comandante", dão prova desse fascínio.

45 Curiosamente, Che Guevara é reverenciado na cidade como uma espécie santo, tanto pela fama posterior, como pela força dos retratos de seu cadáver estendido na cadeira, exibido pelas tropas governistas. Jorge Castañeda (1997) sugere a semelhança do corpo, a barba espessa, o corpo esguio, abalado pela fome e pelas batalhas, com a imagem de Cristo na via crúcis. 
não ao Guevara mítico - herói impávido e sem medos - e sim ao homem falível, desamparado, abandonado pelos aliados e cercado pela força superior dos inimigos.

Mais que uma adesão simplória à figura do guerrilheiro, o sujeito o questiona - ou melhor dizendo, questiona a si mesma, reflexivamente, ao recriar como interlocutor a imagem do comandante tombado - e faz do exemplo humano (mais que político) de sua causa, da identificação com sua luta, um tenso processo de questionamento coletivo.

Uma das estratégias discursivas utilizadas para aproximar o sujeito indagante e o herói em seu calvário é a marcação textual de um espaço comum, que os aproxima, e que não poderia ser outro senão o continente latino-americano:

\section{Súbito vimos ao mundo e nos chamamos Ernesto. Súbito vimos ao mundo e estamos} na América Latina.

O poema é o mais longo do livro e está dividido em oito partes. Entre elas há uma alternância de diferentes estilos de verso, com espaço para a métrica fixa e rimada e para o verso livre e prosaico. A primeira dessas partes tem como cenário a quebrada do Yuro, local da derradeira resistência dos guerrilheiros liderados por Che:

Na quebrada do Yuro eram 13,30 horas

(Em São Paulo

era mais tarde; em Paris anoitecera; na Ásia o sono era seda)

$\mathrm{Na}$ quebrada do do rio Yuro a claridade da hora mostrava seu fundo escuro:

as águas limpas batiam sem passado e sem futuro. Estalo de mato, pio de ave, brisa nas folhas era silêncio o barulho

a paisagem (que se move) está imóvel, se move dentro de si lavando

(igual que uma máquina de lava 


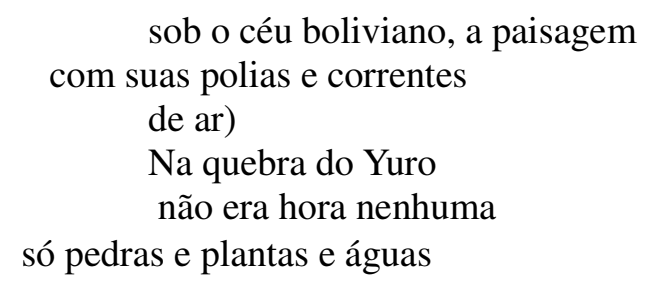

Nessa altura, mais importante que o espaço é a figuração do tempo: determina-se 13:30h como momento exato do tiroteio, um instante situado no passado cronológico pela marcação verbal ("Na quebrada do Yuro eram 13:30 horas") mas presentificado na envergadura do tempo histórico, como um presente suspenso, um tempo fora do tempo: "Na quebrada do Yuro não era hora nenhuma"; além de um outro tempo, a-histórico, natural, marcado pelo bater das águas "sem passado e sem futuro". A tensão dinâmica entre estas camadas temporais reforçam um quadro presentificado, destinado, por se revelar enquanto discurso, a repetir-se sucessivamente cada vez que ativado por um novo leitor.

$\mathrm{Na}$ segunda parte, a marcação quase jornalística do horário do tiroteio se dissolve na simultaneidade de acontecimentos e espaços, ao mesmo tempo alheios e interligados à tarde boliviana. A claridade da tarde esconde aspectos noturnos. A imagem da noite irrompe como metáfora do drama social, da opressão e da violência. No entanto, esta noite se difere do recorrente jogo entre treva e claridade que apontamos na poesia de Thiago de Mello. A noite da poesia de Gullar não é estática e restrita a uma simbologia pré-definida, ao contrário, é repleta de movimento, "veloz", "se move dentro de si”, sem encontrar saídas óbvias para sua superação na constelação testual. Na poesia de Thiago de Mello, para relembrarmos, as imagens da noite frequentemente são utilizadas como artifício metafórico para anunciar a aurora, sempre inexorável, que se aproxima como um duplo da noite e seus sentidos negativos:

Madrugada camponesa. Faz escuro (já nem tanto), vale a pena trabalhar. Faz escuro mas eu canto porque a manhã vai chegar.

(MELLO, 1984, p. 226)

A verdade é a luz pequena ardendo na escuridão.

Da terra, ela nasce e cresce 
de vida, na tua mão.

(MELLO, 1984, p. 330)

\begin{abstract}
Não quero fazer um poema, quero acender uma estrela para entreter a esperança.
\end{abstract}

(MELLO, 1984, p. 272)

Mas em Gullar o contraste noite x dia, isto é, realidade x utopia, opressão x liberdade, não aparece de maneira tão didática. A noite, pouco frequente em sua poesia bastante solar, surge como momento de agitação, tensão e movimento, como podemos muito bem observar novamente no poema em análise:

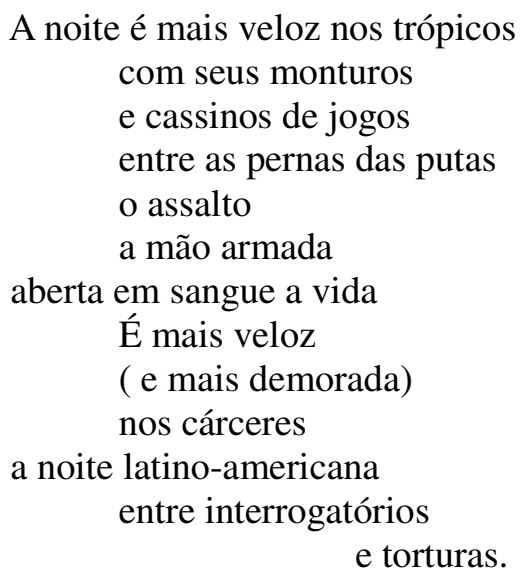

As duas primeiras partes, portanto, capturam, tal como a lente de uma câmera - o ritmo dos versos e a materialidade das imagens se aglutinam de maneira a simular o processo eisensteiniano de montagem cinematográfica - o cenário selvagem no qual "um tiro/ explode em pássaros”, com a sonoridade dos fonemas plosivos reforçando a carga semântica que compõe a cena do tiroteio. Os eventos em torno da luta de Guevara se desenrolam, pois, num espaço próprio do poema, em sua dinâmica impura de tempo, mais profunda que a anterior delimitação jornalística das 13:30h, um tempo fora do tempo, pois "não era hora nenhuma", apenas movimento "da paisagem como um trem".

De repente, na terceira parte, há um corte brusco:

Ernesto Che Guevara teu fim está perto não basta estar certo 
para vencer a batalha

Ernesto Che Guevara

entrega-te à prisão

não basta ter razão

pra não morrer de bala

Ernesto Che Guevara

não estejas iludido

a bala entra em teu corpo

como em qualquer bandido

Ernesto Che Guevara

por que lutas ainda?

a batalha está finda

antes que o dia acabe

Ernesto Che Guevara

é chegada a tua hora

e o povo ignora

se por ele lutavas.

$\mathrm{O}$ verso livre das duas primeiras partes do poema, espalhado plasticamente na folha em branco, dá lugar a uma espécie de "canção". Nas quadras fixas predominam a redondilha menor e rimas recorrentes, com o paralelismo demarcado em cada estrofe, tendo como termo central o interlocutor, no caso o próprio Che. De uma voz lírica fixada em descrever um cenário e criar uma atmosfera, passamos a um diálogo fictício com Che Guevara; é aqui que a situação narrada se pessoaliza na imagem do líder guerrilheiro, que aparece numa situação de enorme dificuldade, sem o ar triunfante do herói, em condição de desamparo extremo, diante do qual é aconselhado, por uma voz lírica perplexa, a desistir: "entrega-te à prisão", "por que lutas ainda?", "é chegada a tua hora". Guevara surge humano e frágil, e é aconselhado a reconhecer que "a bala entra em teu corpo/ como em qualquer bandido" e que "a batalha está finda".

Do drama pessoal de Guevara emerge o dilema da luta política e os questionamentos de uma geração: a guerrilha não conseguira conquistar o almejado apoio popular e os combatentes, exaustos e isolados, viam-se na região acidentada do Yuro cercados por tropas do exército boliviano, os rangers apoiados pelo poder bélico da CIA. Nessa altura do poema é até possível aferir um tom derrotista, trágico, com os revolucionários cercados, na iminência de serem capturados pelas forças imperialistas. A ideologia subversiva é posta em xeque, volta-se sobre ela mesma para questionar-se. O senso de realidade é sentido na lucidez pragmática deste "eu" que se 
dirige ao comandante ferido; o embate social entre a utopia e as forças reacionárias estão mesclados ao dilema individual: o desejo vão de resistência se confronta com a vergonha da derrota consumada, dos limites da ação humana, assumindo este conjunto uma alta dramaticidade.

A quarta parte é a mais narrativa de todas. Os versos são mais longos e irregulares. O tempo cíclico da natureza (contido nas imagens do correr das "águas do Yuro") e o tempo histórico (dado pelo tiroteio que decidiria, de alguma forma o futuro político do país e do continente) misturam-se vertiginosamente em um só movimento, contínuo e apressado:

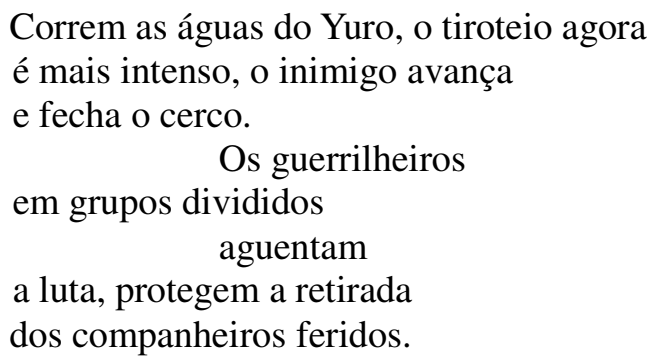

Temos um relato marcadamente realista dos acontecimentos ocorridos naquela noite de outubro. O trecho, bastante documental, poderia ser facilmente confundido com uma nota de jornal ou com o depoimento de algum dos sobreviventes não fosse a disposição poética dos versos: os diferentes níveis de recuo criam uma ordenação solta, exigindo que a leitura deslize conforme as quebras radicais dos versos. A irregularidade é mais que reforço rítmico, é visual, e mimetiza a confusão embaralhada da noite e a velocidade fatídica da ação narrada, com a ação fragmentária e a correria dos combatentes perseguidos. O desconforto do leitor ao remontar a sintaxe estilhaçada entre os versos gera sensações análogas à vertigem dos personagens encurralados na selva, no centro do tiroteio.

Em meio a essa narrativa do confronto entre guerrilheiros e soldados, o poeta desloca bruscamente a ação (ou a sua câmera, se persistimos com uma leitura cinematográfica do poema) para outros lugares e contextos:

Uma greve em Santiago. Chove na Jamaica. Em Buenos Aires há sol nas alamedas arborizadas, um general maquina um golpe. Uma família festeja bodas de prata num trem que se aproxima de Montevidéo. À beira da estrada 
muge um boi da Swift. A Bolsa

no Rio fecha em alta

ou baixa.

Na luta travada em solo boliviano são sobrepostas diversas imagens que aludem ao contexto sócio-político da América Latina. São dados prosaicos, da mais banal realidade, mas que na tessitura do poema são aproximados por um fio de instabilidade que lhes é comum: a chuva, a greve, um general maquinando um golpe, um trem que se movimenta, o boi de uma multinacional que muge ou a bolsa de valores expondo seu saldo irrelevante. Os acontecimentos são simultâneos e ecoam entre os tiros que estalam no Yuro, reunindo num único espaço de tempo diversos fragmentos da realidade latino-americana que ressoam entre si e pesam, como síntese esvaziada, no desfecho trágico do comandante Che Guevara.

Alcides Villaça caracteriza este recurso, bastante frequente na poesia de Gullar, como um tipo de sincronização e a explica do seguinte modo: “A sincronização, ou necessidade dela, parece nascer como efeito de uma recusa, que recai, desde os primeiros poemas de Gullar, sobre a mobilidade fragmentária do mundo(...) O poeta anseia dizer tudo, adotar pontos de vista diferentes, mas simultâneos." (VILLAÇA, 1984, p. 135).

Em seguida, na quinta parte, os versos voltam a ter maior regularidade, tanto na métrica como na disposição que ocupam no papel. A alteração no ritmo - lembremos que o poema transita por vários estilos - está em sintonia com a calmaria advinda após o término do combate. Sai a prosa alucinante dos versos livres e entra a ordem visual e sonora das quadras, com predomínio da redondilha maior e rimas abundantes, embora livremente distribuídas. Che Guevara está capturado e é levado para a pequena cidade de La Higuera, onde fica preso em uma escola nas poucas horas que antecedem a ordem de execução. É o fim do homem audacioso que "Não morrerá das feridas/ ganhas no combate/ mas da mão assassina/ que o abate".

A noite e seu movimento cheios de vertigem termina com "um golpe escondido ao nascer do dia”. O nascer do dia e a morte se relacionam; enquanto a noite era o espaço da luta, do movimento, da dinâmica, a manhã, tradicionalmente relacionada à utopia, é o instante da execução, anticlímax por excelência. O herói, demasiado humano e feito de carne e sangue, não existe mais. A derrota já anunciada no tiroteio se confirma e é descrita sem afetação; o cenário da captura de Guevara não é, a essa altura, cercado de glória e promessas de novas lutas, e sim de uma solidão tragicamente lírica: 


$$
\begin{aligned}
& \text { É o seu último vôo } \\
& \text { sobre a América Latina } \\
& \text { sob o fulgor de estrelas } \\
& \text { que nada sabem dos homens } \\
& \text { que nada sabem do sonho, } \\
& \text { da esperança, da alegria } \\
& \text { da luta surda do homem } \\
& \text { pela flor de cada dia } \\
& \text { É o seu último vôo } \\
& \text { sobre a choupana de homens } \\
& \text { que não sabem o que se passa } \\
& \text { naquela noite de outubro. }
\end{aligned}
$$

O foco recai sobre o voo e, com o recurso da visão aérea ${ }^{46}$, três camadas de espaço se enlaçam, novamente com a exploração da sincronização: primeiro a imagem cósmica, as estrelas "que nada sabem dos homens" e ignoram a luta travada naquela noite; num segundo plano a América Latina, o espaço social e afetivo que justifica e abriga as esperanças postas em marcha; e num terceiro plano, mais imediato, a choupana onde os camponeses vivem a marcha habitual da existência, também alheios ao combate ali travado em seu nome.

É a última referência direta a Guevara no poema. A partir de então, nas três partes seguintes, o esforço narrativo dá lugar à reflexão propriamente lírica. O sujeito ganha contornos próprios, passa a tecer questionamentos, protestar e denunciar. As páginas que correspondem ao desfecho de “Dentro da noite veloz" talvez sejam o mais preciso anúncio do Poema Sujo: o verso livre rico em aliterações, assonâncias e paranomásias, a inserção de termos exilados da lírica tradicional, como os rebuscados nomes das multinacionais, e até a adoção de termos chulos atestam a visceralidade e a pungência presentes no melhor da poesia do autor maranhense.

A imagem da noite e sua agitação veloz voltam a se articular com o contexto sombrio da América Latina: as ditaduras e a tortura, a miséria e a exploração. O fantasma do imperialismo vem à tona através das multinacionais estabelecidas no continente e estas, por sua vez, ganham vida no poema a partir de imagens concretas: a Armour Company cintila numa lata de ervilha, a Cerro de Pasco Corporation resplandece no rosto do trabalhador das minas de chumbo e silicose. Os fragmentos do subdesenvolvimento latino-americano vão sendo amalgamados sugestivamente pela

46 Recurso também caro à poesia de Gullar, vide o poema "Fotografia aérea", de Muitas Vozes. A estratégia permite ao sujeito imprimir uma visão ampla do cenário, ao mesmo tempo que coloca em perspectiva os eventos sociais, que, diluídos na grandeza da cena contemplada, perdem seu aspecto totalizador. 
voz lírica, reunindo num todo particular a soma de detritos, resíduos, ruídos que compõem a parte final do longo poema.

Mais que isso, a crítica ao sistema capitalista se materializa no próprio sujeito, é ele que tem seu futuro e opções definidas a contragosto pelas exigências tirânicas do modelo (representadas pelos nomes estrangeiríssimos das empresas multinacionais) que ordena e determina a ordem social:

\author{
Serei cantor \\ serei poeta? \\ Responde o cobre (da Anaconda Copper): \\ Serás assaltante \\ e proxeneta \\ policial jagunço alcagueta. \\ Serei pederasta e homicida? \\ serei viciado? \\ Responde o ferro (da Bethlehem Steel): \\ Serás ministro de estado \\ e suicida \\ Serei dentista? \\ talvez quem sabe oftalmologista? \\ otorrinolaringologista? \\ Responde a bauxita (da Kaiser Aluminium): \\ Serás médico aborteiro \\ que dá mais dinheiro
}

Por fim, temos um belo desfecho que marca a transitoriedade já apresentada no título. $\mathrm{O}$ martírio de Che Guevara é ressignificado em seu fim trágico. A possibilidade de mudança é dada pelo potencial transformador expresso na noção de que "a vida muda". A fórmula é repetida cinco vezes na última parte do poema, ora em símiles que levam em conta imagens da natureza, que ratificam o sentido de mudança e renovação ("A vida muda como flor em fruto", "A vida muda como água em folhas") ora com um sentido em aberto, destacando assim a ambiguidade do termo "muda", que qualifica a vida tanto em seu ímpeto de mudança como em sua mudez, isto é, a ausência de sentido ou respostas para os problemas então levantados.

Dentro deste embate entre mudança e mudez, entre a imagem do herói tombado e a necessidade de transformação social que supere a "noite latino-americana", o poema parece fincarse nesta última. O movimento é de superação e tomada de consciência, e se encerra com a esperança de que a luta engendrada por Guevara na selva boliviana se multiplique em mais 
movimento e agitação popular, pois é na sua inserção no movimento perpétuo da história que germina o exemplo do combatente incompreendido, abrindo caminhos para que a caída do mártir se converta em novas revoltas. O trânsito da derrota individual para a esperança do triunfo coletivo é sublimada na cadeia aliterativa de "muda", "morto" e "multidão" formando um contínuo que encerra o poema:

a vida muda

a vida muda o morto em multidão. 


\section{3 - A América vista do exílio}

\section{1- Os anos de chumbo e a geração de exilados}

O golpe militar de 1964 representou uma dura derrota às forças políticas da esquerda brasileira ao quebrar uma sequência de governos eleitos que vinha desde o final dos anos 40 . Germinava, nos anos anteriores ao golpe, a esperança de se colocar em prática uma série de reformas com vistas à diminuir drasticamente as desigualdades sociais no país, fortalecer o aparato do estado nacional, aprofundar conquistas trabalhistas, consolidar a democracia e garantir a reforma agrária. A tomada do poder por parte dos militares, apoiados pela burguesia nacional, resultou num desânimo imediato, um choque, uma perplexa desilusão dos atores envolvidos na luta política daqueles anos. O abalo era visível também na cena cultural, cujos membros eram, em sua maioria, entusiastas das mudanças que, por algum momento, pareciam reluzir com maior intensidade no horizonte brasileiro.

A euforia política dava lugar a um momento de perplexidade. Intelectuais e artistas imprimiam em seus trabalhos os caracteres da incerteza, da mea-culpa e da reafirmação dos compromissos então firmados. Viria o tempo de perseguições, torturas, assassinatos? Qual seria a postura do regime militar? Seria breve ou, tal como nas alegorias tecidas pelo realismo mágico latino-americano, roubariam a cena tiranos revestidos de uma perpetuada eternidade?

Para surpresa de muitos, os primeiros anos da direita militar no poder foram de enorme efervescência do ponto de vista das manifestações culturais. Como explica Roberto Schwarz, durante o governo Castelo Branco a repressão dos militares recaía com maior truculência na militância direta, ou seja, sindicatos, lideranças do partido comunista, líderes das lutas no campo, estes sim eram violentamente perseguidos. Enquanto isso, nas grandes cidades ainda existia alguma tolerância às manifestações culturais de viés contestador ou mesmo de orientação abertamente revolucionária. De tal modo que "apesar da ditadura de direita há [naquele momento] relativa hegemonia cultural da esquerda no país" (SCHWARZ, 1978, p. 62).

Segundo Roberto Schwarz, os eventos promovidos por uma encorpada esquerda cultural não chegavam a incomodar o regime por conta do caráter localizado e restringido de sua atuação. Era 
curto o alcance de livros, shows e peças de teor subversivo. Por isso, apesar de terem essas manifestações a ambição radical, e nada amigável, de derrubar a ditadura, a circulação deste material era restrita a uma parte da juventude urbana, acadêmica e de classe média. Fazia-se, no período imediatamente posterior ao golpe de 64, uma arte de fundo catártico, que gerava um nicho mercadológico fiel, sem assustar as forças hegemônicas com seus rituais e epifanias políticas.

A indústria cultural dava seus primeiros passos no Brasil, incentivada pelo governo militar, que tinha na mercantilização da cultura e na subordinação dos mercados editorais e fonográficos às diretrizes do capitalismo monopolista uma das forças de seu "projeto modernizador" (PELLEGRINI, 2001, p. 80). A arte de contestação "liberada" pelo regime era, portanto, marcada pelo público jovem, de classe média, militantes-consumidores já convertidos ao ideário socialista, ou ao menos esquerdizante, reunidos em rituais apoteóticos, mas de pouco alcance mobilizador. Poderíamos, assim, afirmar que no plano cultural:

esta situação cristalizou-se em 64, quando grosso modo a intelectualidade socialista, já pronta para prisão, desemprego e exílio, foi poupada. Torturados, e longamente presos, foram somente aqueles que haviam organizado o contato com os camponeses, os operários, marinheiros e soldados. Cortadas naquela ocasião a ponte entre o movimento cultural e as massas, o governo Castelo Branco não impediu a circulação do ideário esquerdista, que embora em área restrita floresceu extraordinariamente. (SCHWARZ, 1978, p. 62)

A interpretação deste período histórico, tal como proposta por Roberto Schwarz, não está imune a algumas críticas. Ao salientar o escasso potencial agregador e mobilizador das manifestações culturais, fica subtendido que a vitalidade da arte anti-ditatura praticada num período imediatamente após o golpe poderia não passar de mera concessão do regime; um regalo de misericórdia dos generais aos antigos membros do front cultural pecebista, premiando-os com alguma liberdade por confiarem astutamente em sua total inefetividade.

Falta nesta hipótese, para completarmos o entendimento deste cenário, uma análise um pouco mais detida sobre a rápida capacidade de reorganização de alguns grupos da esquerda cultural após o golpe militar. Com notável velocidade, a incredulidade geral frente à queda do governo Jango, marcada pela sensação coletiva de que todos os projetos fermentados na década anterior tornar-se-iam pó com o triunfo das forças conservadoras, foi convertida em um difuso, mas contundente, desejo de resistência. O show Opinião, organizado pelo grupo homônimo já mencionado mais atrás, do qual Gullar era um dos membros, foi parte desta tática de resposta 
instantânea ao baque sofrido.

Nara Leão, Zé Kéti e João do Vale subiam ao palco diante de uma multidão ainda atordoada, estarrecida por desconhecer os rumos que a luta política iria tomar a partir de então. Conforme discute Heloísa Buarque de Hollanda (2004), o tom festivo do encontro - em oposição à sisudez e a melancolia esperada diante do impasse histórico vivido - não pretendia oferecer lição alguma a respeito da ultrajante derrota política que o golpe significou para a esquerda. Tampouco se esforçava em apresentar linhas de atuação, encontrar culpados, ou gerar novas promessas para a juventude que ali se reunia, extasiada, para fazer do espetáculo um evento cívico, verdadeiro ato de comunhão coletiva e expurgação do desolador contexto que se apresentava. A ideia era apenas romper o silêncio, mostrar que apesar de confusas e atônitas, existiam vozes dissonantes e "mais que nunca é preciso cantar”, como ecoava no refrão da música “Quarta-feira de cinzas”, de Vinícius de Moraes, e que "podem me prender, podem me bater que eu não mudo de opinião", como dizia a letra da música que dava nome ao espetáculo.

O mesmo vale para o êxito da Revista Civilização Brasileira (RCB), também pensada na esteira do golpe e lançada em março de 1965. Ela reunia colaborações de intelectuais de várias correntes teóricas, marcando um espaço amplo de debate a respeito da condição do país e da América Latina. Como já dissemos mais atrás, tanto Ferreira Gullar como Thiago de Mello eram presenças constantes nas páginas da revista, o primeiro com poemas e artigos sobre teoria cultural ${ }^{47}$, o segundo com diversos poemas $\underline{48}$. Além da sua importância para a compreensão do pensamento de esquerda no Brasil pós-golpe, a RCB merece dedicada atenção neste trabalho por ser um dos raros momentos em que a atuação estética-política dos dois autores analisados esteve coletivamente circunscrita num único projeto, em que, se não havia um contato direto entre os dois, sem dúvida eram abundantes os interlocutores comuns, marcando um ponto de relativa convergência

47 Eleonora Ziller Camenietzki difere bem a atuação de Gullar no SDJB, como "crítico de artes plásticas”, e na RCB como "teórico da cultura"; além da abrangência do objeto que considera em seus estudos, outra diferença básica é a postura do analista, não mais concentrado primordialmente no debate estético, mas desviando seu faro questionador para os problemas da cultura em um país subdesenvolvido como o Brasil. (CAMENIETZKI, 2006, p. 92-93).

$48 \mathrm{Na}$ Revista Civilização Brasileira Gullar publica inúmeros artigos de teoria cultural, dentre eles "Por que parou a arte brasileira", no primeiro número da revista; no segundo volume publica os poemas "O açúcar", "Maio 1964", "Agosto 1964" e "Dois e dois: quatro", todos eles reunidos futuramente em Dentro da noite veloz; também têm o seu perfil, com dados bio-bibliográficos e uma entrevista, apresentado no quarto número da revista. Já Thiago de Mello, além de trabalhar constantemente na organização da RCB, publica um longo poema no número três da revista, realiza entrevistas e também tem um perfil publicado em suas páginas (REVISTA CIVILIZAÇÃO BRASILEIRA, 1965-1967). 
(ideológica, muito mais que estética) que iria se diluir radicalmente nos anos seguintes.

Portanto, mais que uma simples concessão estratégica da ditadura, a resistência da cultura de esquerda no pós-golpe foi resultado de uma reação imediata, automática, por isso pouco consequente, de várias frentes que ao invés de amargurar o retumbante fracasso da "cultura pedagógica", a fragilidade da arte frente ao conservadorismo regressivo, tão internalizado na formação histórica da sociabilidade brasileira, saíram às ruas em número elevado. Se há alguma surpresa na resposta de nossos atores culturais ao golpe militar foi a de manterem praticamente inabalada a crença numa transformação social profunda posta em movimento pelo gatilho da arte:

A infinita repetição de argumentos, conhecidos de todos - nada mais redundante, a
primeira vista, que o teatro logo em seguida ao golpe - não era redundante:
ensinava que as pessoas continuavam lá e não haviam mudado de opinião, que com
jeito se poderia dizer muita coisa, que era possível correr um risco. (SCHWARZ,
1978, p. 80)

Se antes cabia à arte conduzir as massas para a desejada revolução, agora ela era proclamada a primeira trincheira na luta contra a ditadura. A cumplicidade para com um público - localizado, mas suficientemente amplo - livrou, neste primeiro momento, os artistas de uma perseguição mais intensa, pois num momento de consolidação das forças militares no poder, os efeitos de uma investida truculenta poderia resultar num abalo da imagem do regime: caso a violência governamental criasse um mártir entre os ruidosos aglomerados de opositores, formados por artistas reconhecidos e estudantes de classe média, uma explosão de protestos seria imediata e, talvez, incontornável para o regime.

No ano em que o golpe foi consumado, Thiago de Mello cumpria missão diplomática no Chile. Rapidamente foi afastado de seu posto, voltando para o Brasil em seguida. Ferreira Gullar era presidente do CPC da UNE, além de manter a atividade de jornalista e crítico de arte. O primeiro, estarrecido, esperava voltar ao país e ajudar na resistência contra a ditadura, enquanto o segundo, tão logo chegou a confirmação do golpe, filiou-se ao partido comunista como gesto de solidariedade aos companheiros que novamente, após um período de crescente importância institucional, atuariam na clandestinidade. Este gesto iria transformar subitamente os rumos da sua vida nos anos de chumbo.

Ferreira Gullar encontrara no grupo Opinião um sólido foco de contestação, sobretudo nas peças de teatro que cria em parceria com Oduvaldo Viana Filho, o Vianinha. Sua produção volta-se 
para o teatro, a televisão e para os ensaios teóricos - os livros Cultura posta em questão (1966) e Vanguarda e Subdesenvolvimento (1974) são dessa época - deixando a poesia em segundo plano.

O impasse que vivenciara ao término de A Luta Corporal, quando alcançara a incomunicação, a ininteligibilidade máxima, com o poema "Roçzeiral", lhe rendeu uma crise de linguagem que as experiências com as vanguardas não conseguiram contornar. Depois de descobrir que a aventura de elaborar um poema que brotasse ao mesmo tempo que a linguagem que o dava forma era tão somente uma marcha irremediável para o obscurantismo estéril, Ferreira Gullar descobriu com o "Poema Enterrado", ponto máximo de sua dedicação ao plano neoconcreto, que ele, um poeta, estava vagando pelo domínio das artes plásticas. Daí um longo silêncio poético, ao menos na publicação de livro inédito. Sua atenção se volta para formas que, a seu ver, seriam instrumentos mais úteis para a causa que defendia. Os poemas de cordel, escritos neste período, são a prova de que o poeta estava imbuído de um projeto político que dividia espaço com a busca de uma expressão mais íntima.

Já Thiago de Mello segue caminho contrário: intensifica sua produção literária na medida em que adere à militância política. Ao converter de vez sua poesia à instrumento na luta contra a ditadura - tônica particularmente perceptível nos livros Faz escuro mas eu canto, de 1966, e Canção do amor armado, de 1967 - o poeta publica com grande intensidade e, como consequência, com uma irregularidade visível na perda do rigor formal das suas publicações. Nesta nova fase o ato criador adquire um caráter de urgência: o compromisso ético do canto sufoca qualquer filtro técnico ou arquitetura verbal mais apurada. Seus poemas se pretendem faróis guiando a emancipação humana; os sentimentos do sujeito passam a ser diretamente relacionados ao contexto político no qual está vivendo e o caráter humanizador e afetivo de seu canto insinuam como farsa qualquer intenção acadêmica ou esteticista que abale o laço de cumplicidade desejado entre o poeta e o leitor:

Trabalho de homem para homem, palavra que me faz ser, escrever não seja ofício alheio ao chão de viver. Tenha sempre a tessitura alada da claridão, mas principalmente seja de serventia a quem vive ferido na escuridão.

(MELLO, 1984, p.355) 
Enquanto Gullar é contido, teorizando sobre o sentido popular da poesia e buscando uma forma de conciliar na sua linguagem os dramas do sujeito em viva sintonia com a realidade social que o envolve, Thiago é voluntarioso e elabora sua poesia como instrumento utilitário, "que seja de serventia a quem vive ferido na escuridão". Enquanto Gullar migra sua atuação intelectual para outras atividades, deixando parcialmente em suspenso a sua condição de poeta, Thiago de Mello se entrega com paixão à produção literária, imprimindo nela os signos do protesto e fazendo, em seus livros, o que Gullar fazia no teatro Opinião, ou seja, estabelecer uma resistência à ditadura, comover denunciando, ou denunciar comovendo, tudo isso sem perder o propósito esclarecedor próprio da arte empenhada.

Vejamos dois exemplos drásticos desta expressão. Em Gullar o coloquialismo brutal, cru, direto no âmago dos objetos cotidianos - por isso mesmo carregados de ideologia - como vemos nestas linhas que esboçam uma arte poética:

Todas as coisas de que falo são de carne como o verão e o salário.

Mortalmente inseridas no tempo, estão dispersas como ar no mercado, nas oficinas, nas ruas, nos hotéis de viagem.

(GULLAR, 2009, p. 174)

Ao passo que em Thiago de Mello as imagens são mediadas pelo juízo abstrato do sujeito, mais evanescentes, moralizadas, sem um terreno histórico mais consistente. Trata-se mais da busca humana por justiça, dos sonhos mais elementares de igualdade, do que de crítica erguida frente a um contexto histórico específico:

Escrevo esta canção porque é preciso.

Se não a escrevo, falho com o pacto que tenho

Abertamente com a vida.

E é preciso fazer alguma coisa

para ajudar o homem.

(MELLO, 1984, p. 323)

A sensação moral de que "é preciso fazer alguma coisa" surge com uma clareza profética, talvez até carregada de culpa, mas não se aplica a atos concretos. Quase sempre o "fazer algo" acaba costurando um traço metalinguístico que retorna ao próprio canto: canta-se porque é preciso, porque é preciso fazer algo pelo homem, bastando, no fim das contas, o canto a si mesmo, e a 
missão está cumprida. Seria, paradoxalmente, uma arte pela arte genuína, não estivessem o canto e a vida fundidos pela experiência íntima do autor. Pois "este ofício de escrever/ sem tirar nem pôr, é o mesmo/ que o ofício de viver; / quero dizer o de amar.". (MELLO, 1998, p. 14)

Entre 1964 e 1968 a conjuntura nacional passa por mudanças significativas. É um momento, ainda segundo Roberto Schwarz, no qual uma nova geração de estudantes, os mesmos que formavam a esquerda festiva, responsável pelas primeiras articulações culturais contra a ditadura, alcançava a maturidade para novamente se organizarem com os trabalhadores da cidade e do campo, bem como com as outras forças sociais que se organizavam. Dentro de seu raciocínio, o crítico marxista alega que em 1968 a juventude, agora organizada em semi-cladestinidade, dera um grande passo na direção de ultrapassar as barreiras da ideologia e interferir de fato na estrutura social. Deixava de ser massa barulhenta, mas de pouco alcance popular, portanto de pouca eficácia revolucionária, para se tornar, de fato, uma ameaça ao regime. Ao se tornar uma ameaça concreta, a direita passa a temer a atuação destes novos grupos e suas ações isoladas: o sequestro de diplomatas estrangeiros, roubos a bancos, proliferação de grupos armados: o fechamento do cerco, a tortura, a repressão violenta, própria dos regimes desta natureza, passava, então, a ser uma consequência óbvia.

Diferentemente das alas mais exaltadas do PCB, que viam na radicalização das forças críticas à ditadura um amadurecimento político - essa nova massa que surgia com capacidade de "dar base material à ideologia" - Ferreira Gullar posicionou-se contra a radicalização dos grupos de esquerda. Crítico da luta armada, Gullar terá seu nome lançado como candidato ao diretório do PCB na tentativa de, com seu prestígio, garantir a vitória da chapa moderada diante do avanço dos grupos determinados a seguir a aventura guerrilheira. Em análise futura, o poeta relembra o debate travado dentro do partido:

Enquanto os setores mais maduros da esquerda afirmavam que o caminho para
derrotar a ditadura era a luta pelas liberdades democráticas, aproveitando-se de
todas as brechas que o regime fora obrigado a deixar, a ultra esquerda embarcava
no delírio da luta armada, deslocando a disputa para o terreno onde o adversário
tinha mais força e tirocínio. Assim, as ações terroristas e a repressão passaram a se
alimentar uma da outra. (GULLAR, 1998, p. 17)

Como última chave para tecermos um painel desse momento, podemos completar dizendo que o aumento substancial da repressão, culminando no pérfido AI-5, é engendrado não ao acaso, 
apenas como resposta às crescentes forças de oposição, mas é também ápice de uma etapa de consolidação do governo militar. Se a perseguição de intelectuais e artistas, a censura e o aumento desenfreado da truculência eram atitudes temerárias para os militares no período imediatamente posterior ao golpe, já em meados de 1968 o espaço para expor sua faceta mais autoritária era possível devido à euforia social propiciado pelo dito "milagre econômico". Pois:

Passa-se a viver um clima de ufanismo, com o Estado construindo seus grandes monumentos, estradas, pontes e obras faraônicas, enquanto a classe média, aproveitando-se das sobras econômicas do 'milagre', vai, maravilhada, comprar seus automóveis, televisões coloridas e apartamentos conjugados para veraneio. No campo da produção cultural a censura torna-se violentíssima, dificultando e impedindo a circulação de manifestações de caráter crítico. Não mais os militantes são violentamente perseguidos, como professores, intelectuais passam a ser enquadrados à farta na legislação coercitiva do Estado, sendo obrigados, em muitos casos, a abandonar o país. (SCHWARZ, 1978, p. 76)

As aparentes conquistas no âmbito econômico acabam sendo utilizadas como cortinas para desviar, ocultar, ou em certos casos até justificar, a violência cometida nos porões da ditadura. Junto ao avanço da luta armada, a ilusão desenvolvimentista, fundamentada na opção econômica de atrair a qualquer custo os investimentos estrangeiros, alavancando ainda mais o abismo da dependência econômica, foram fundamentais para que o regime expusesse toda sua vocação coercitiva e inaugurasse uma era perseguições, torturas e exílios, pois, agora, "dispondo da força, dispensavam o clamor popular" (Idem, p.78).

Thiago de Mello é um dos primeiros a sofrer com a perseguição do regime. Após perder seu posto de adido cultural no Chile, o poeta volta ao Brasil para tomar posição na luta contra o governo militar. Em 1965 é preso numa manifestação política - lembremos que a "condescendência" inicial dos militares para com os eventos culturais não era estendida para os protestos políticos propriamente ditos. Desse mesmo protesto participaram intelectuais importantes como Antonio Callado, Carlos Heitor Cony e Glauber Rocha, todos eles presos durante vários dias. A passagem é lembrada, ou melhor, denunciada pelo poeta em dois poemas denominados "Iniciação do cárcere", ambos do livro Canção do Amor Armado (1966). Os quinze dias que passou na prisão são lembradas neste poema de forte tom memorialista. Nele a solidão do cárcere é revestida de uma significação aberta, comunicante, afirmando-se enquanto voz de contestação à tirania e refundando o pacto com a liberdade contida na imagem da alvorada ou refletida na metáfora da flor, desaguando, enfim, no anúncio da união do povo para a construção da utopia, expediente típico de 
sua obra:

\section{Iniciação do cárcere}

É preciso que Amor seja a primeira palavra a ser gravada nesta cela. Para servir-me agora e companheira seja amanhã de quem precise dela.

Não sei o que vai vir, mas se desprende dessa palavra tanta claridão, que com poder do povo me defende e me mantém erguido o coração.

No muro sujo, Amor é uma alegria, que ninguém sabe, livre e luminosa como as lanças de sol da rebeldia, que é amor, é brasa, e de repente é rosa.

(MELLO, 1984, p. 275-276)

O poema é de uma cadência séria, quase solene. A sonoridade grave, farta de vogais fechadas ("e", "o" e nasais) e as rimas bem medidas fazem relembrar seu livro de estreia, no qual a apuração verbal era tônica de sua produção poética. A obra, no entanto, não se restringe a esta atmosfera carregada, reforçada pelo campo semântico que indica a opressão ("prisão", "tortura", “cárcere"). O espaço sombrio da prisão é atenuado, se não suprimido, pelo fundo sublime da resistência: a palavra Amor, em letras maiúsculas, a rosa, a claridão, apontam o horizonte da utopia, quebrando a negatividade do drama individual em prol da esperança na redenção coletiva.

O vocábulo "Amor" gravado na cela da prisão possui várias significações: primeiro o de resistência, de reafirmar as convicções no espaço do inimigo. Entretanto, e aqui temos uma especificidade do autor, a palavra escolhida não é de protesto, tampouco uma palavra de ordem, afirmação de uma causa política, é a palavra "Amor”, com sua carga abstrata, sua tessitura diáfana, idealista, tantas vezes mal vista pela literatura de protesto.

Uma outra função da palavra escrita na cela é servir de companheira a outros que ficarem presos ali, isto é, a palavra assume um poder solidário, sua simples evocação tem poder de abrir caminhos; sem saber direito como, talvez resguardando o mistério mais profundo da poesia, o poeta não explica como aquele conjunto de letras, com sons e formas desenhadas na parede, poderá ser luz, consolo ou mesmo explodir em rosa, amiga da rebeldia, mas o simples gesto de escrevê-la é um 
compromisso humanizador, compromisso que o liga ao leitor que a encontrar e tomá-la como amiga. Neste sentido, a palavra cheia de promessas, brilhando altiva em ambiente hostil bem poderia servir como uma espécie de arte poética de Thiago de Mello, o traço característico e ordenador de sua obra nesse período.

Por fim, podemos comentar rapidamente um outro aspecto presente no poema, o do testemunho. Estudando romances publicados durante a ditadura, Regina Dalcastagné constata a presença de um "espaço da dor", que faz essas obras serem pensadas como "um lugar onde a memória é resguardada para exemplo e vergonha das gerações futuras" (DALCASTAGNÉ, 1996, p. 25). A palavra escrita sempre guardou o desejo inquieto de durar, por isso a grafia do vocábulo "Amor" nos porões da ditadura é por si só resistência da memória, mas não apenas a memória da dor, do sofrimento, dos absurdos cometidos naquele período, como também a das esperanças mais singelas capazes de brotar do terror e do medo e permanecer viva na parede da memória, ou seja, no corpo-texto do poema. Livre de qualquer ódio político e pronta para o perdão, a palavra de Thiago de Mello cumpre a missão de salvaguardar a memória da violência sofrida, ao mesmo tempo que faz perdurar as promessas que justificavam e iluminavam aquela situação de dor e solidão.

Logo após a libertação, o exílio torna-se a saída mais conveniente, graças à situação estável que conquistara no Chile durante os anos em que por lá morou. Seu retorno para o país andino era uma solução urgente devido ao risco de reincidir na polícia política dos ditadores. Era o início do exílio imposto. Após o grande período de exílio opcional, Thiago era privado de seu país e retornava para o país que o havia acolhido nos anos anteriores.

Ferreira Gullar, por sua vez, sofrerá como efeito imediado do golpe a perda da presidência do CPC, que é extinto, enquanto a UNE, sua mantenedora, é lançada na clandestinidade. Nos anos seguintes, sua atividade cultural é exercida sem grandes reviravoltas, até o decreto do AI-5. Daí em diante, apenas o medo era companheiro constante: o risco de cair nas mãos dos adversários permeava sua rotina com uma tensão sem trégua, seja na redação do jornal em que trabalhava, na organização dos espetáculos, no anúncio de amigos desaparecidos. Trata-se de um terror próprio dos regimes totalitários: apoiados numa imagem de onipresença punitiva, o Estado espalhava o pânico entre seus desafetos declarados. A sensação de risco mortal, sentida constantemente num país marcado pela ausência de liberdade política, ganha contornos poéticos no poema "Maio de 1964": 


\section{Maio de 1964}

Na leiteira a tarde se reparte

em iogurtes, coalhadas, copos

de leite

e no espelho meu rosto. São

quatro horas da tarde, em maio.

Tenho 33 anos e uma gastrite. Amo

a vida

que é cheia de crianças, de flores

e mulheres, a vida,

esse direito de todos

que nenhum ato

institucional ou constitucional

pode cassar ou legar.

Mas quantos amigos presos!

Quantos cárceres escuros

onde a tarde fede a urina e terror.

Há muitas famílias sem rumo esta tarde

nos subúrbios de ferro e gás

onde brinca irremida a infância da classe operária.

Estou aqui. $\mathrm{O}$ espelho

não guardará a marca de meu rosto,

se simplesmente saio do lugar

ou se morro

se me matam.

Estou aqui e não estarei, um dia, em parte alguma.

Que importa pois?

A luta comum me acende o sangue

e me bate no peito

como o coice de uma lembrança.

(GULLAR, 2009, p. 169)

O poema oferece um testemunho dos primeiros movimentos da ditadura. É também indício de uma transição importante na obra do autor. A revolta, a rebeldia, a identificação com as classes exploradas e a formulação de uma "luta comum" dão o tom inequívoco do poema de protesto; entretanto, o eu do poema se questiona, se indaga (“que importa pois?") não apenas a respeito das questões mais pontuais da realidade social, mas também se demora em divagações mais íntimas. A situação inicial, ou o "susto inspirador" que Gullar defenderia mais tarde como a grande marca de 
seu processo criativo ${ }^{49}$, é o seu reflexo no espelho, tema repisado pela tradição como índice de crises identitárias e autoanálise. Aqui, porém, o espelho em que o poeta mira a si mesmo é o da vitrine de uma leiteria, numa tarde ensolarada, num país que vive sob regime de exceção. O mesmo sujeito que tem uma gastrite, dois pés e mãos, apresenta a esperança, o desejo tão humano "que nenhum ato inconstitucional ou constitucional pode cassar".

A aproximação entre o poeta e os homens simples da rua não se dá por um desejo voluntário e professado do sujeito em ser parte da urbe em movimento, e sim pelos elementos que vão brotando vivamente no poema: a visceralidade do corpo e a revolta, a esperança, que adquirem o mesmo índice de naturalidade. As referências à ditadura são econômicas e precisas: o ato inconstitucional, as prisões dos amigos, a tortura, além do próprio título, "Maio 1964", montam um contexto em que a iminência da morte ("se morro/ se me matam") é mensurada e pressentida pela interioridade inquietante do sujeito.

O poema anuncia uma situação de pânico e terror que iria constituir um capítulo lamentável tanto na história do país como na biografia de Ferreira Gullar. Em dezembro de 1968 ele é avisado por colegas do partido que um dos companheiros, após ser duramente torturado, acusou o nome de Gullar aos militares. O risco era iminente: a imposição de seu nome, contra a sua vontade, para a direção do partido, fazia de Gullar um alvo particularmente cobiçado. O destino de diretores nas câmaras de tortura era dos mais brutais, culminando frequentemente na morte.

Assim que descobre a delação forçada que o comprometia, Gullar passa a viver como fugitivo dentro de seu próprio país. A liberdade antes escassa é reduzida a nada. Passa breves períodos de esconderijo em esconderijo: a casa de sua sogra e o apartamento de amigos acolhem o poeta, já impedido de sair às ruas e com seu nome na lista de procurados.

Mesmo com todo cuidado, acaba caindo nas mãos da repressão. Levado para interrogatório, é torturado e passa alguns dias presos. O sofrimento, o pavor da morte iminente mesclado com a esperança da libertação são tratados em outro dos poemas deste período:

49 Nas entrevistas mais recentes o autor tem dito recorrentemente que a tônica de seus poemas é um flash inicial, um susto advindo das inusitadas experiências do cotidiano, que o leva a escrever. Ver as entrevistas para a Revista Bravo, março de 2009, e à Folha de São Paulo, em 02 de junho de 2010. 


\title{
O prisioneiro
}

\author{
Ouço as árvores \\ lá fora \\ as nuvens \\ Ouço vozes \\ risos \\ Uma porta que bate \\ É de tarde \\ (com seus claros barulhos) \\ como há vinte anos em São Luís \\ como há vinte dias em Ipanema \\ Como amanhã \\ um homem livre em sua casa.
}

(X3, PE, Vila Militar , Rio, 2/1/69)

(GULLAR, 2009, p. 194)

O "amanhã" de liberdade - representado no poema pela segurança do lar - sonhado pelo poeta tardaria ainda quase oito anos para se concretizar. Com a ajuda da pressão de intelectuais e amigos, Gullar é liberado, mas continua sendo perseguido pela polícia política. A vida clandestina segue até 1971, quando o partido lhe oferece condições razoáveis de segurança para que ele fugisse para a Argentina e, de lá, seguiria para Moscou, onde realizaria um curso sobre teoria marxista. Era o início do doloroso período de exílio.

Nos anos seguintes passaria por Moscou, Santiago, Buenos Aires e Lima. Voltaria a ser poeta de fato, já que as atividades teatrais e teóricas lhe afastaram momentaneamente da publicação de versos e escreveria, no exílio, sua obra mais aplaudida, o Poema Sujo. Sobre o poema "O prisioneiro", que trata dos dias em que ficou preso no Rio de Janeiro, é interessante notar, ao fim do texto principal, a inscrição do local e data no qual foi escrito: (X3, PE, Vila Militar , Rio, 2/1/69). O artifício, diga-se de passagem, é muito comum na poesia de Thiago de Mello, para quem a inscrição supra-textual da situação de escrita acaba contribuindo para gerar o contorno de proximidade entre o sujeito lírico e o leitor, tão marcante de sua poética. Mas em Gullar é, sem dúvida, um caso isolado, digno de atenção. Indicar o local no qual foi preso, oferecendo elementos biográficos e contextuais para o poema, o aproxima da ideia de testemunho. O breve poema, carregado de traumas e ressentimentos, assume o papel de documentar as experiências de alguém exposto a uma 
situação de violência social efetuada por um governo totalitário.

Narrando uma passagem dolorida de sua vida, Gullar deseja, evidentemente, mais que tematizar um capítulo autobiográfico: ele quer chamar atenção para uma situação de violência institucionalizada que vitimou milhares de vítimas como ele e se constitui como momento-chave da história recente do Brasil. Trazendo as marcas da situação de escrita e, de certa maneira, relativizando a autonomia do poema em relação ao contexto social no qual foi concebido, o artifício recria, à luz da experiência particular e da linguagem poética, um evento histórico de lamentáveis proporções. A poesia não se omite em participar da vida pública e dos embates que afloram na política brasileira. Calar-se não é uma opção, só é possível escrever em consonância com a realidade imediata, devido ao seu peso dilacerador e a necessidade de confrontar-se com ele, de superá-lo:

$$
\begin{aligned}
& \text { Como ser neutro, fazer } \\
& \text { um poema neutro } \\
& \text { se há uma ditadura no país } \\
& \text { e eu estou infeliz? }
\end{aligned}
$$

(GULLAR, 2009, p. 190)

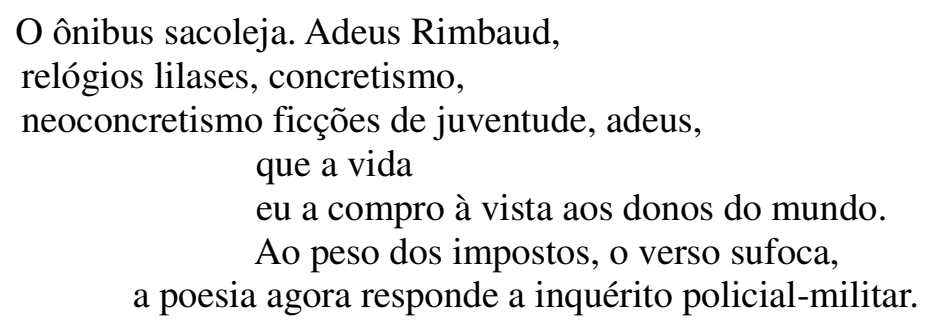

(GULLAR, 2009, p. 170)

Atualmente afloram interessantes estudos que relacionam a literatura com o momento histórico correspondente à ditadura militar no Brasil $\stackrel{50}{ }$. Pensando as interações entre o contexto de violência e repressão política-cultural com problemas de ordem narrativa, como a escrita do testemunho, do trauma, da memória, estas pesquisas têm ajudado a compreender as características do período e a oferecer novas abordagens para o texto literário. São leituras que não se prendem exclusivamente nos elementos linguísticos responsáveis pela "literariedade" destes textos, mas que estabelecem trânsitos interpretativos entre o texto e a história, entre memória e trauma, bem como

50 O já mencionado texto de Regina Dalcastagne (1996), as análises de Jaime Ginzburg da obra de Clarice Lispector (2009) e Caio Fernando Abreu (2008), os ensaios de Márcio Seligmann-Silva (2003), além da sólida produção acadêmica ligada aos grupos de pesquisa "Literatura e Autorismo" (CNPq) e "Literatura e Violência" (FAPESP), são exemplos deste importante debate. 
as diversas forma de representar a violência.

Não obstante, as contribuições mais importantes destas tendências críticas têm sido desenvolvidas no campo da prosa, tomando como objeto de reflexão romances, crônicas, contos, ou mesmo diários e cartas, mas quase nunca textos poéticos. A falta de teorização que aproxime a reflexão sobre a poesia brasileira com as noções de testemunho e o autoritarismo do regime militar pode ser explicada por dois motivos: 1) a tese legada pela tradição crítica moderna de que a poesia é o domínio da experiência íntima, centrada no reino da expressão e, por isso, incompatível com a descrição objetiva da realidade. Tal tese é desenvolvida, no mínimo, desde a estética de Hegel e tem uma de suas formulações mais contundentes no livro Que é a literatura? (1989), de Jean-Paul Sartre, no qual o autor defende como termos inconciliáveis o engajamento e a especifidade da lírica 51; 2) a ideia já cristalizada de que o período correspondente à ditadura militar brasileira representou um "vazio cultural" no país, particularmente sentido na produção poética. A demanda por textos líricos, de acordo com esta visão, ficou quase que totalmente a cargo da música popular, cuja produção era realmente próspera neste período e para onde teriam migrado os principais talentos daquela geração, deixando a poesia no vão dos debates estéreis, das intrincadas celeumas linguísticas, restando pouquíssimos autores dignos de análise.

Contrariamente a esta silenciosa exclusão da poesia nos debates sobre testemunho no Brasil, acreditamos que a breve leitura que fizemos do poema "Iniciação do cárcere", de Thiago de Mello, e dos poemas "O Prisioneiro" e "Maio 1964", de Ferreira Gullar, podem vir a contribuir para o debate em torno destas questões, sem dúvida, fundamentais para a compreensão e apreciação da poesia brasileira daquele período.

A intensa perseguição do regime militar brasileiro fez com que Thiago de Mello e Ferreira Gullar encontrassem no exílio a saída mais viável perante os riscos que corriam no país. Ao terror

51 Ao desenvolver suas reflexões, Sartre conclui: "compreende-se facilmente a tolice que seria exigir um engajamento poético. Sem dúvida a emoção, a própria paixão - e por que não a cólera, a indignação social, o ódio político - estão na origem do poema. Mas não se exprimem nele, como num panfleto ou numa confissão. À medida que o prosador expõe sentimentos, ele os esclarece; o poeta, ao contrário, quando vaza suas paixões em seu poema, deixa de reconhecê-las; as palavras se apoderam delas, ficam impregnadas por elas." (SARTRE, 1989, p. 17-18). A prosa seria o domínio da palavra banal, da expressão corriqueira, utilitária, manjada pelo escritor para sustentar ideias, ao contrário da poesia, cuja marca maior seria o caos da interioridade, a luta sangrenta contra a linguagem, o hermetismo sempre hostil ao engajamento. Certamente as teses de Sartre não se aplicam aos poetas estudados neste trabalho, tampouco abarca uma forte tendência da lírica moderna, de Brecht a Neruda, que empresta à linguagem poética a rebeldia e o desejo de mudança. A esta visão de Sartre se contrapõe, por exemplo, as ideias de Adorno desenvolvidas no célebre ensaio "Lírica e sociedade" (ADORNO, 2003). Apesar de desaprovar o engajamento explícito, Adorno estabelece as bases para uma reflexão mais profunda entre as relações sutis e complexas entre lírica e sociedade. 
do tirocínio e truculência do regime, os dois passariam a ter na experiência degenerativa do exílio o desdobramento doloroso daquele contexto histórico. A privação do verdadeiro lar, o corte abrupto do contato com familiares e amigos somavam-se ao impedimento de atuar diretamente no contexto político de seu país, tudo isso faz com que os dois poetas entrem numa fase em que a melancolia aparece como aspecto marcante de suas obras.

Saudade de casa, sentimento de impotência, revolta e estranhamento são danos psicológicos frequentemente associados ao estigma do exílio, mas, passando detidamente por eles, pretendemos chegar a um outro ponto menos comentado: como seguir cantando a América Latina agora que ela vem a ser cenário forçado das mais duras privações e angústias vividas por estes sujeitos? Para encararmos essas perguntas, passaremos da apresentação do contexto histórico que fez com centenas de brasileiros fossem impossibilitados de viver livremente em seu próprio país para tecermos algumas breves considerações a respeito do exílio na literatura, a partir das contribuições de alguns dos autores que se dedicaram a examinar esta questão.

Como bem se sabe, a experiência do exílio têm sido desde os primórdios tema fecundo para a arte literária. Da Odisséia à Divina Comédia, da formação dos estados nacionais à escala formidável de desterrados, exilados e imigrantes do século XX fizeram, de acordo Edward Said, de nosso tempo uma época de pessoas sem lar (SAID, 2003, p. 46-47). Há um conjunto de obras da tradição literária criadas por escritores nesta condição, seja por privação política, seja por debilidades de outra ordem, econômica ou cultural, todas estas capazes de levar um aglomerado assombrosamente grande de artistas, intelectuais, trabalhadores a deixarem seus países de origem em busca de melhores condições de vida. No caso de nossa contemporaneidade, a persistência da angústia derivada do exílio é marca importante da literatura atual e aponta para a persistência do drama da falta da segurança do lar, das tradições e heranças culturais e afetivas.

No entanto, se há algo capaz de unir os exilados de toda natureza é a condição de incontornável desacordo com o local onde se tentará a dura, e até certo ponto impossível, tarefa de erguer um novo lar. Cria-se um embate profundo com a cultura que, por menos estranha que lhe pareça, estará para sempre em débito com o local familiar, os hábitos e saberes que lhe deram o primeiro sentido para mundo. Faz parte de seu horizonte o retorno ao lar natal, ainda que este esteja murado pelos conflitos políticos, acometido pela opressão ou longamente condenado à miséria econômica. No exílio, a plenitude não passa de delírio, a aflição torna-se parte indissociável da 
rotina e muitas vezes narrar a "fratura incurável entre o homem e um lugar natal" (SAID, 2003, p. 46) passa a ser a única maneira de compensar o tempo irreversível, fundando na escrita um novo lar, ainda que provisório, ainda que frágil ${ }^{52}$.

Os livros escritos por Ferreira Gullar e Thiago de Mello durante a primeira metade dos anos 70 podem ser interpretados em suas relações diretas com o momento de exílio vivido por seus autores, bem como permitem uma articulação com a situação histórica da América Latina, marcada neste período, como se sabe, pelos governos ditatoriais. A saída do país, em tese, permitiria alongar o horizonte de abordagem dos problemas sociais e políticos do Brasil. O olhar distanciado, ainda mais para dois autores tão envolvidos nas polêmicas mais apaixonadas daquele momento, poderia trazer novos arranjos para aprofundar a encenação poética dos projetos em conflito. Naturalmente, esta mudança de foco caberia também para a própria vertente americanista de seus poemas: trafegando por países da América Latina, testemunhando agitações revolucionárias e participando de derrotas monumentais - como o golpe militar chileno - o propósito do comunitarismo poderia vir a ganhar nuances inovadoras, principalmente pela descentralização do olhar idealizado, com os pés fixados no Brasil, para uma vivência prolongada nos países interlocutores desta fulguração.

Não por acaso, os anos de exílio têm sido abordados com grande interesse pelas mais recentes especulações em torno da obra de Ferreira Gullar. Após lançar seu livro de memórias, Rabo de Foguete: os anos de exílios (1998) vários de seus principais intérpretes lançaram novos olhares sobre a poesia deste período, que inclui o aclamado Poema Sujo $\underline{\underline{53}}$.

Rabo de Foguete é um relato sobre os anos em que o autor passou vagando de um lugar para outro, primeiro perseguido pela ditadura brasileira, depois sendo obrigado a deixar o país, assistindo a golpes de direita no Chile e na Argentina, correndo graves riscos pela sua condição de militante de esquerda. A narrativa do livro é objetiva e serena, esforçando-se para não deixar transparecer impressões, ressentimentos, emoções derivadas do trauma decorrente da privação da liberdade política: exalta no estilo o relato despojado dos acontecimentos, ocultando em camadas mais sutis as ressonâncias internas da reclusão, da revolta e da saudade dos familiares, elementos que ganham corpo na poesia escrita nos anos 70, como vemos no sintomático poema "Exílio":

52 Que o diga o já proverbial, e frequentemente mal lido, dito de Fernando Pessoa: "Minha pátria é a língua portuguesa".

53 Dentre estes estudos vale citar o de Davi Arrigucci (1998), "Tudo é exílio", e o artigo de Cris Gutkoski (2007), "Estruturas da fuga do exílio em Ferreira Gullar". 


\section{Exílio}

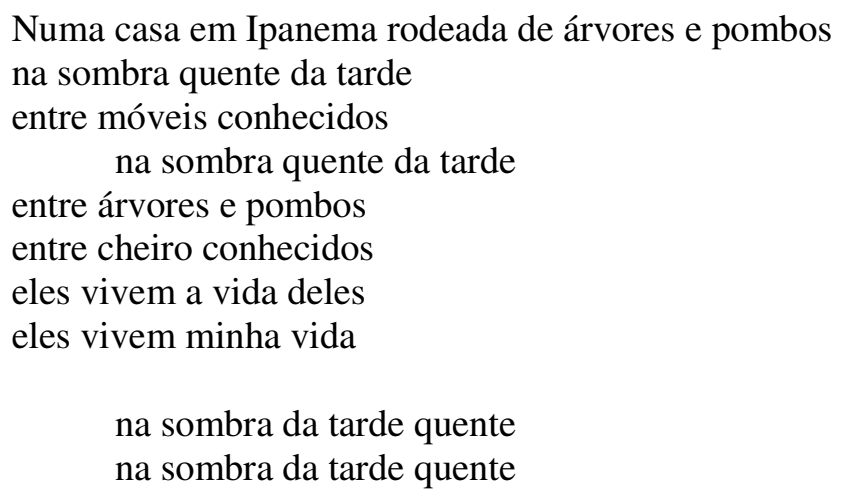

(GULLAR, 2009, p. 221)

Neste breve poema de condensada emotividade, o exílio é tratado pela ótica da perda e da ausência. O cenário é Ipanema, mas uma Ipanema imaginada, espaço dos afetos e da segurança idílica do lar. A imagem da "tarde quente" é repetida várias vezes no poema de modo a marcar um obsessivo desejo de regresso aquele espaço, modulando um contraponto implícito com a frieza vivida no momento de enunciação, exprimida pela voz do exilado. Nesta casa sonhada - a casa que está impossibilitado de retornar - os objetos são conhecidos, o clima aconchegante, os rostos familiares, flutuam na memória como um passado presentificado.

A descrição do lar apresenta elementos altamente positivos: os cheiros conhecidos, os móveis conhecidos, a tarde agradável. Dos contornos da casa, em Ipanema, entre amálgamas lucidamente dispostos e repostos, surge, ao fim, a imagem dos que vivem naquele cenário tão acolhedor, mas com ordenação sintática oposta a apresentada no início do poema: "na sombra quente da tarde" se transforma em "na sombra da tarde quente". Os amigos, a esposa, os filhos: "eles vivem a vida deles"; e se chega a constatação central, embaralhada entre os versos que se repetem e se renovam em novas formulações, misto de delírio e indício de melancolia extrema, de que "eles vivem a minha vida", cravando, assim, a existência abalada do sujeito, a vida suspensa pelo exílio e ininterruptamente vivida (sem ele) na tarde radiante do Rio de Janeiro.

Já na obra de Thiago de Mello o impacto do exílio é, num primeiro olhar, menos danoso. São poucos os poemas que tratam diretamente da condição de exilado, ao menos no sentido negativo que lhe é mais comum. A tristeza destrutiva e raivosa, da vida em suspenso, como no poema de Gullar, é revertida, em seus versos, num amistoso desejo de regresso. A vivência mais fraternal com os antigos amigos chilenos ameniza o ímpeto pelo regresso ao Brasil. Não que ele 
deixe de existir, é claro, mas não chega a marcar seus poemas pela amargura e o incômodo da distância. Qualquer ressentimento parece, nestes livros de Thiago de Mello, dar lugar à gratidão pelo acolhimento dos novos companheiros, como podemos ver no poema "39 anos de um cidadão brasileiro":

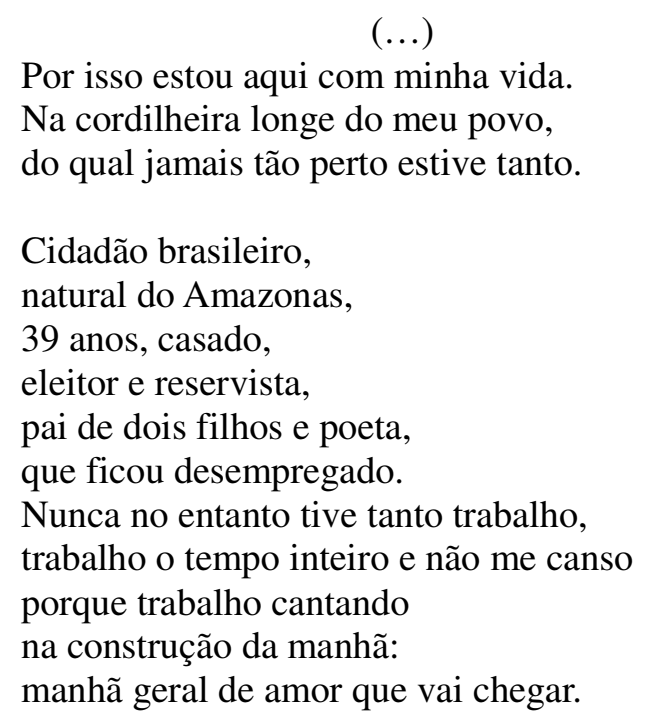

(MELLO, 1984, p. 235)

O sofrimento, enquanto sentimento individual, parece estar abolido de sua poesia nestes anos de máximo empenho em cantar a justiça, a solidariedade e o futuro. As dores individuais não cabem ali, só são mencionadas com uma dose de culpa, para serem em seguida negadas. A aparente angústia de estar fora do país, "longe do meu povo", é rapidamente atenuada pela confiança de que “jamais estive tão perto”. Todas as derrotas e sofrimentos objetivos (o exílio, a saudade do Amazonas onde nasceu, a distância dos familiares) são facilmente convertidos em contentamento abstrato. Uma pena, pois ficamos apenas com o retrato parcial e pouco convincente dos grandes exemplos recolhidos das vidas mais humildes, dos triunfos caprichosos da amizade, desta manhã iluminada cantada pelo poeta (de uma luz enfadonha e tão intensa que não nos deixa ver o que ela de fato poderia significar), sem um aprofundamento no drama humano que ligaria o sujeito ao momento histórico vivido, prenhe de sentidos e experiências.

\section{2- A experiência chilena: ascensão e queda}

A passagem de Thiago de Mello e Ferreira Gullar pelo Chile coincide com um momento de 
complexidade política talvez sem precedentes na história da América Latina. A construção do socialismo era uma realidade docemente vivida pelos intelectuais do país e pela grande comunidade de exilados que ali se estabeleceu buscando refúgio diante de perseguições sofridas em seus países de origem. Ficando apenas em nomes brasileiros mais conhecidos, podemos citar Paulo Freire, Mario Pedrosa, Fernando Henrique Cardoso, além de tantos outros, que encontravam-se asilados no Chile no começo dos anos 70. O contexto político é bem conhecido: Salvador Allende subia ao poder como o primeiro governo declaradamente socialista eleito democraticamente na América Latina.

A esperança de mudanças efetivas alimentava o desejo de participação social tendo em vista a melhor distribuição de renda, a reforma agrária e a estatização das empresas estrangeiras. O triunfo upista (a Unión Popular (UP), vitoriosa nas eleições gerais, que abrangia os partidos comunista, socialista e social-democrata) ampliava a tradição diplomática chilena de oferecer asilo político, intensificada pela disposição do novo governo em acolher as mais diferentes personagens da esquerda latino-americana, alvos corriqueiros das diversas ditaduras instauradas no continente. Sobre esta tradição diplomática chilena, vale mencionar um trecho do pomposo discurso de Pablo Neruda ao receber Thiago de Mello em seu país: "Chile acogió siempre al pensamiento perseguido. En eso estamos de acuerdo gobernadores e gobernados. El asilo contra la opresión no es solo un verso, es el laurel de Chile, nuestro común orgullo”*.. (apud MELLO, 1984, p. 206)

A recepção de Thiago é amistosa, festiva, rodeada de hospitalidade e carinho. Com base nela, poderemos compreender aquele tratamento fraterno que sua poesia dedicou ao país que o acolheu e aos seus muitos anfitriões neste período. O Chile já era para ele uma espécie de segundo lar. Amigos chilenos, e também brasileiros exilados, aguardavam a definição de sua situação no Brasil: a prisão, a liberdade e logo a necessidade de retornar ao país onde cumprira, até meados de 1965, missão diplomática. Por conta desta familiaridade com o país andino, esta segunda passagem é menos traumática. O peso dilacerante do exílio é, de alguma forma, atenuado por uma vivência intensa, relativamente estável e segura, incluindo um papel político informalmente ligado ao poder central.

Por conta da atmosfera promissora - o testemunho de seus ideais sendo colocados em marcha num país latino-americano - os livros que escreve neste período refletem a profundidade da

* O Chile acolheu sempre ao pensamento perseguido. Neste aspecto, estamos de acordo governantes e governados. $O$ asilo contra a opressão não é apenas um verso, é a láurea do Chile, nosso comum orgulho. 
conversão de sua poesia à instrumento de luta política. São poemas que têm a vida mesma como matéria; não a vida especulada, hermética, inalcançável dos primeiros livros, mas a vida dos humildes, irmanados pelo empenho acolhedor de sua linguagem celebratória. A alegria passa a ser uma busca compulsiva: não há mais espaço para dores individuais, o compromisso com a construção de um mundo mais justo e fraterno torna-se o tema central, quase exclusivo de seus escritos. A linguagem poética busca no mundo social e nas utopias seu compromisso primeiro. Elementos já assinalados em seus primeiros livros ganham nova roupagem: poesia e vida formam um contínuo, alimentam-se um do outro, assumindo o compromisso quase profético de anunciar a emancipação humana, a liberdade e o amor. Se em Silêncio e Palavra dizia de maneira densa e algo enigmática "Somente sou quando em verso", agora, participando como entusiasta e espectador da construção do socialismo no Chile, escreverá sem margem para rodeios líricos:

Escrevo esta canção porque é preciso.

Se não escrevo, falho com o pacto que tenho abertamente com a vida. É preciso fazer alguma coisa para ajudar o homem.

Mas agora.

(MELLO, 1984, p. 323)

O envolvimento de Thiago de Mello com parte da intelectualidade chilena e brasileira, em festas, encontros e projetos comuns $\underline{54}$ gerava uma situação de vitalidade cultural e afetiva (inclusive por se apaixonar e casar com uma chilena) brutalmente oposta à vida de Gullar durante aqueles anos.

A chegada do poeta maranhense a Santiago era marcada pela revolta. A maneira patética como seu nome fora lançado para o diretório central do partido, fato que lhe obrigaria a deixar o país, ainda lhe causava remorso e frustração. A viagem para Moscou, o curso sobre marxismo e os seis meses que por lá passou, estranhando a língua, o clima e com saudades da família, contribuíram para que Gullar chegasse ao Chile já castigado pelo sentimento profundo de solidão e deslocamento. Pior que isso: sua chegada coincide com uma nova fase da aventura socialista

54 Um dos casos mais emblemáticos da atuação dos exilados brasileiros na construção do socialismo upista é o de Mario Pedrosa. O crítico de arte participou ativamente da construção do Museo de la Solidariedad, projeto artístico/político que envolveu a colaboração de figuras de primeira ordem da intelectualidade chilena e que contava com a participação efetiva do próprio Allende. Ver LOPEZ (2010). 
chilena. Dissipava-se rapidamente o clima de euforia pela vitória nas urnas e o governo de Allende, ao começar a colocar em marcha as mudanças tão aguardadas, se deparava com um tecido social extremamente complexo, no qual as diversas forças que o levaram ao poder começavam a expor suas divergências, abrindo espaço para uma encorpada investida reacionária. Logo o golpe militar começava a pairar sobre o regime, sendo, a partir de certo momento, uma questão de tempo. Diferentemente de Thiago de Mello, Gullar chegara ao Chile num estágio em que o otimismo em torno da construção do socialismo se convertera em apreensão por parte dos simpatizantes do governo de Allende. Em maio de 1973, quando entra no país, o poeta maranhense tinha a sua frente um cenário pré-apocalíptico em que ninguém em sã consciência negaria que uma reviravolta terrível poderia acontecer a qualquer instante.

Um dos capítulos do livro de memórias Rabo de Foguete (1998) oferece um painel objetivo e lúcido da tensão política que Gullar encontrou ao chegar ao Chile. Por se tratar de um livro de memórias, ou seja, escrito anos após a vivência dos acontecimentos narrados, quando "o tempo já aliviara os traumas" (GULLAR, 1998, p. 3), evidentemente as ideias e opiniões nele desenvolvidas dificilmente coincidem fidedignamente com as convicções do poeta no calor daquele momento histórico ímpar ${ }^{55}$. No entanto, a leitura de Rabo de Foguete ajuda a esclarecer algumas passagens da trajetória do autor, muitas delas decisivas para sua produção poética naquele período, além de lançar um olhar bastante ácido sobre a realidade dos exilados brasileiros nos anos de chumbo da ditadura militar. Deste livro, citamos uma passagem em que Gullar faz uma sucinta, embora contundente, análise dos primeiros meses do governo socialista:

Um dos graves erros cometidos pelo governo socialista foi, logo de saída, dar uma

55 Algumas conclusões a respeito da nebulosa conjuntura chilena, que neste livro Gullar profere como simultâneas aos acontecimentos rememorados - sobretudo as de cunho mais negativo - não são totalmente compatíveis com os escritos que elaborou naquele momento. Não é nossa intenção, e nem poderia ser, decifrar a verdade dos fatos, desvendando o que o autor realmente acreditava, se no ceticismo trágico que figura na narrativa de Rabo de Foguete, ou numa esperança algo desconfiada - mas ainda assim convicta na defesa do projeto upista - que podemos ler em alguns poemas do período. O mais adequado é entender o livro de memórias como um lúcido relato daqueles anos. Lucidez esta acumulada nos anos que se seguiram, amadurecida com as reflexões posteriores, sendo certamente difícil imaginar que qualquer intelectual envolvido como testemunha na trama chilena tivesse, no jogo de forças confusas daqueles meses, uma opinião límpida, coesa e inflexível dos acontecimentos em curso. Tal esclarecimento se deve ao fato de, havendo um aparente descompasso entre o juízo contido em Rabo de Foguete (onde impera um olhar crítico, distanciado, apoiado no desenrolar futuro dos acontecimentos) e os poemas deste período (às vezes entusiastas das mudanças em curso, entregue ao momento presente e consciente da imprevisibilidade de toda ação política) ficaremos sempre com a verdade do poema, mais interessante e sintomática da experiência histórica nele contida. Em síntese, utilizaremos o livro de memórias como uma útil ferramenta para entendermos os poemas escritos no exílio, porém relativizando-o sempre que julgarmos que o olhar futuro do autor passa a deformar, ao invés de iluminar, os sentidos desta poesia. 
aumento salarial de $100 \%$ a todos os trabalhadores do país, o que provocou o consumo desenfreado e o esgotamento de estoques. As prateleiras ficaram vazias e os preços subiram vertiginosamente. A necessidade de atender ao consumidor fez convergir para a produção de bens de consumo os recursos que deveriam dirigir-se para setores básicos da economia. Ao mesmo tempo, o esforço para suprir o comércio e minorar a escassez de mercadoria era frustrado pela ação sabotadora da burguesia, que comprava e estocava tudo que não era perecível. (...) Essa situação era gravada pelo bloqueio econômico imposto ao Chile pelos EUA. (GULLAR, 1998, p. 144)

Ferreira Gullar passou a dividir um apartamento com outro colega brasileiro, mantendo, porém, pouco contato com outros intelectuais brasileiros na mesma situação que a sua. Assim, como nos anos em que viveu clandestino no Brasil, o poeta voltava a viver numa angustiante solidão agravada pelo temor crescente de um golpe, já maquinado por alguns setores conservadores das forças armadas.

É este o momento em que a pressão social e política do momento vivido começa a se mesclar com as lembranças da infância, com a saudade do país natal, amigos e familiares, demarcando um movimento de extrema importância na obra do poeta. Os poemas escritos durante o exílio afastam-se do tom popular-nacionalista marcante nos Romances de Cordel e ainda visíveis nos primeiros poemas de Dentro da Noite Veloz, como "Homem Comum", "Poema Brasileiro", "Meu povo, meu poema" e "A bomba suja". A matéria social passa a ser internamente mediada pela experiência particular do sujeito, erguida entre os escombros do desamparo, da ausência de afetos, da sensação de desconforto e perda resultante do exílio.

O ano de 1973 é marcado pela escassez de produtos nas lojas, greves sucessivas e uma tensão social insustentável. Os conflitos aumentavam os receios de um golpe militar iminente, que ganharia forma em setembro deste mesmo ano. O país estava divido. Alguns dos intelectuais de esquerda, antevendo a violência da repressão militar, começam a deixar o Chile, outros, como Gullar, temem a perseguição decorrente do golpe; os riscos são imensos, de ser preso, torturado e possivelmente assassinado como aliado de Allende ou ainda o de ser mandado de volta para o Brasil, onde condições não menos aterradoras esperavam estes militantes. Thiago de Mello ainda se irmana a uma eventual resistência, mas sua poesia, ainda leal ao governo de Allende, dá indícios de quão grande é a delicadeza do momento:

Acho (escrevo no centro da desunião) que ainda pode se erguer um arco-íris. Mas também pode dar cupim no esteio 
da casa que é preciso edificar.

Lá nos meus campos, onde a dor é a mesma, quando a chuva socava o chão cansado, se diz que um dia, um dia a casa cai.

(MELLO, 1984, p. 344)

No dia 11 de setembro de 1973 o teatro do golpe estava armado e o palácio de La Moneda foi impiedosamente bombardeado. Allende se recusava a deixar o centro administrativo, mas as tentativas de resistência ao golpe mostrara-se inoperantes e seriam, para Gullar e Thiago, alvo de duras críticas em seus poemas. Por fim, o presidente foi assassinado, o general Augusto Pinochet assumia o poder dando início a uma das mais violentas ditaduras militares da América Latina. Na sequência do golpe, resta aos poetas, ainda incrédulos, levantar as inevitáveis perguntas: que ensinamentos a experiência da derrota deixaria na mente daqueles que a testemunharam? Como atuar diante da iminência da guerra civil? Quais os impactos daquele fracasso na luta que se desenvolvia em outros países da América Latina?

A derrocada do projeto upista torna-se, então, matéria fecunda para Gullar e Thiago. Os últimos poemas de Dentro da Noite Veloz, de Gullar, e todo o livro Poesia Comprometida com a minha vida e a sua $a^{56}$, de Thiago, estão carregados de referências ao período: a experiência do exílio, no plano pessoal, e o testemunho da construção do socialismo e o impacto do golpe militar chileno, no plano histórico. Em um dos mais interessantes poemas que escreve sobre o período, Thiago de Mello revela uma enorme frustração com as forças leais a Allende, completamente indefesas diante do potencial bélico dos militares. O olhar do poeta vai remontando todo o itinerário do fracasso upista: o governo desarticulado, as bases populares de apoio confusas entre a defesa pouco promissora do regime e o conformismo diante da reação direitista, tudo isso apresentado a partir da ótica do exilado, com o olhar ambíguo de alguém que ao mesmo tempo se sente parte daquele projeto arruinado mas que não perde o olhar do "de fora", de quem assiste aos acontecimentos como estrangeiro. Passemos, pois, ao poema:

\section{O que me espantou}

$56 \mathrm{Na}$ abertura desta obra, o autor já demarca a experiência vivida no Chile como um tema central do livro: "Thiago de Mello: caboclo amazonense de Barreirinha, poeta e cantador, e companheiro da manhã, sentado na margem esquerda do rio Reno, o rio poluído onde os peixes se afogam, no inverno da cidade de Mogúncia, aonde teve de chegar, tangido pelo incêndio monstruoso que lavrou na cordilheira do Andes em setembro de 1973" (MELLO, 1984, p. 315). 
Não foi a multidão indo para casa

(nós no meio dela, disfarçando), cabeça baixa, as pernas pesadas, seguindo a ordem que o inimigo lhe dava.

Eram operários, homens e mulheres.

Eram homens de todas as idades, subindo silenciosos a Grande Avenida.

Nenhum brado, nenhum braço erguido.

Nem foi a organização perfeita do inimigo, a pontaria espantosa de seus aviões, o rigor implacável do seu ódio.

Nem a ingenuidade dos que atenderam ao turvo e meloso apelo da monstruosidade humana repetido pelo rádio.

Pois acreditaram na idiossincrasia, e de mão beijada se entregaram ao reino das trevas e do ranger de dentes, onde até hoje, tirante os que foram mortos, aprendem todos os escalões do escárnio.

O que me espantou foi o assombro que de repente, desorbitado, o chão fugindo, o ar faltando, eu vi se erguer no olhar, no peito, nas mãos que não se achavam, daquele companheiro marinheiro de tanto mar, quando ele compreendeu, depois de tanto acreditar amando, que as barricadas, os grupos de combate, os cordões de milhares, a vanguarda de fogo, não iam chegar, não iam se erguer, não, e que os planos e projetos de resistência (escorriam de brasa as suas lágrimas) eram planos e projetos de palavras.

(MELLO, 1984, p. 346-347)

O poema é de uma abrangência notável. De modo denso e sugestivo percorre os principais dilemas anteriores à consumação do golpe militar de 11 de setembro. $\mathrm{O}$ olhar do sujeito lírico contém o leve traço da memória: resgata entre lembranças abaladas o dia da morte de Allende. O tom é de avaliação e melancolia. A construção e o exame crítico dos eventos ocorridos no dia do golpe estão mesclados a uma situação de crise do sujeito. A memória do golpe ganha vida através 
de imagens de desconcerto, "o chão fugindo", "o ar faltando", a "Grande Avenida", índices de um cenário urbano quase apocalíptico, de refugo utópico, mas também marca de introspecção de um $e u$ que busca calcular os efeitos dos eventos relembrados em sua própria subjetividade.

O título do poema, "O que me espantou”, atua como refrão elidido no início de cada estrofe. A ideia de espanto não é enunciada diretamente, quebrando o que poderia ser uma conexão entre os segmentos do poema e, consequentemente, tornando fragmentária a exposição do sujeito. Com uma afetação contida, a voz lírica percorre os fatos que ajudam a entender o horror do golpe: os militantes fieis a Allende, com os quais o sujeito se identifica, caminhando humilhados ("cabeça baixa, as pernas pesadas"), pequeninos diante da Grande Avenida; o poder de fogo do exército, antes menosprezado pelo governo socialista, "a pontaria espantosa de seus aviões"; a propaganda de direita nas rádios, "o turvo e meloso apelo da monstruosidade humana", conclamando os “cidadão de bem" a apoiarem o exército na "libertação" do país e os ecos estridentes da burguesia chilena, solidária ao golpe; e enfim, colocado como o espanto maior, a ilusão de uma resistência armada ("planos e projetos de palavras"), a derrota sem luta, sem barricadas ou grupos de combate.

Vale notar, porém, que o espanto maior, apresentado na última estrofe, surge não da conjuntura apresentada (que para a historiografia dominante são os condicionantes que explicam parte do êxito do golpe) e sim do desamparo individual, do companheiro privado de lutar, da derrota consumada sem a eclosão do combate, a princípio julgado necessário pelo sujeito do poema. Em meio ao cenário histórico rigorosamente montado no poema, emerge o drama individual, a crise subjetiva dos derrotados. Em outro poema, também de Poesia Comprometida..., é a violência do golpe e o terror instaurado que são denunciados pela voz lírica:

Lá na Alameda de Bernardo O’Higgins
e no sangue chileno que escorria
dos corpos dos obreiros fuzilados,
levados para a fossa em caminhões
pela ferocidade que aos domingos
sabe se ajoelhar e cantar os salmos.
Lá na terra marcada como um boi
pela brasa voraz do latifúndio.

(MELLO, 1984, p. 324).

Mais até do que se dedicaram a cantar o breve e tenso período de construção do socialismo no Chile, o desastre do golpe militar levanta questões de ordem individual e coletiva capazes de despertar nos dois poetas estudados a necessidade de desenvolver um balanço da derrota, rever 
erros, reforçar convicções. O baque exige destes sujeitos uma inflexão, de modo que imprimem nos poemas deste período a marca do auto-exame, não como silêncio mas como forma de manter a integridade destes atores em meio a um momento de refluxo ideológico.

O peso desalentador da experiência chilena na obra dos poetas estudados pode ser entendido à luz da interpretação que Benjamin Abdala Jr. dá ao processo social e cultural, a partir de sua leitura da historicidade contida no mito de Ícaro. Este herói trágico cai dos ares ao alçar seu voo sem seguir as instruções clássicas de equilíbrio e prudência apresentadas por seu pai e também projetor de suas asas, Dédalus, que o ordenava a voar somente em alturas medianas, para que o calor do sol não ofendesse as asas de cera. Refletindo sobre o voo e a queda de Ícaro, Benjamin Abdala Jr, afirma:

Importa é reproduzir no gesto o princípio de juventude que embala não
propriamente o preconcebido vôo trágico da personagem mitológica, mas a
possibilidade de esse princípio se reconfigurar - pela práxis individual e coletiva -
em novos e contínuos vôos, pois que a queda não é necessariamente definitiva -
um rito circunscrito à repetição sem história. No limite, quem se embalou pela
corrente "quente" da utopia - a busca autêntica da felicidade - pode se ver, após
deparar-se diante da evidência de fulgurações mais amplas, em movimento de
queda. (ABDALA, 2003, p. 30)

Da mesma forma, a experiência histórica testemunhada pelos poetas no Chile representa um intervalo entre o choque da utopia em ruínas (consciência da imprevisibilidade concernente a toda ação política) e a busca de energia para alimentar novas, e mais seguras, decolagens. Vencido o projeto político que mirava a justiça social pregando a transformação profunda da sociedade chilena, cabe aos autores recolher dentre os escombros deste projeto um sentido para aquela experiência social.

O momento de revisão é complexo e dramático, se prolonga em vários poemas e altera o estatuto lírico das obras seguintes, tanto as de Gullar como as de Thiago. Este balanço crítico também pode ser compreendido como uma espécie de luto decorrente da decepção frente a queda de Allende, conforme vimos no poema "O que me espantou". Encerrado este momento de crise e ordenação das subjetividades após o desastre chileno, podemos medir as transformações que ele acarreta na poesia dos dois autores.

Thiago de Mello optará pela ressignificação daquela derrota, transformando, bem ao gosto de seu temperamento poético, Allende em herói de uma luta que prossegue, malgrado o reconhecimento dos erros e o longo pesar diante da queda presenciada. Se o poema "O que me 
espantou" corresponde ao luto, ao embate melancólico com o fracasso da experiência socialista no Chile, o poema que o segue no livro Poesia comprometida..., afirma a dialética da experiência social e a demarcação de novas potencialidades subjetivas. Vale reparar como a ideia de "sobras" indicam o impacto da derrota, de uma interioridade em crise, enquanto o verbo "avançar" prefigura os novos passos, ou novos voos, para seguirmos na metáfora de Ícaro, ainda que o avanço ainda seja lento, calcado nas feridas que seguem abertas.

Muito perdi, mas amo o que sobrou.

Alguma dor, pungindo cristalina,

alguma estrela, um resto de campina.

Com o que sobrou, avanço devagar.

Se avançar é saber, lâmina ardendo,

na flor do cerebelo, porque foi

que a alegria, a alegria começando

a se abrir, de repente teve fim.

Mas que avançar no chão ferido seja

também saber o que fazer de mim.

(MELLO, 1984, p. 348)

Por sua vez, o movimento da poesia de Ferreira Gullar após viver o triste episódio da história chilena é mais sutil. Nota-se nos poemas seguintes uma ampliação do seu espaço de militância poética, fugindo do esquematismo mais didático e de denúncia social, para tecer uma abertura para a infância e as memórias. Este retorno aos dilemas da memória e da expressão, surgirá como estratégia para manter sua integridade subjetiva em meio aos escombros da ideologia abalada.

Tal movimento é iniciado já nos últimos poemas de Dentro da Noite Veloz, será consagrado no Poema Sujo, e continuará gradativamente corroborado em sua poesia, ao ponto de alcançar nos livros mais recentes uma larga distância dos temas sociais mais imediatamente voltados ao que se costuma definir como uma postura de engajamento poético. O movimento é também previsto por Benjamin Abdala Jr., que o demarca como resposta possível, e válida, diante de uma etapa de refluxo histórico, pois "uma das estratégias, para se preservar, pode ser contrair-se, fixando numa ilha pessoal" (ABDALA, 2003, p. 32)

Se levado a cabo na profundida que o processo histórico exige, a reflexão poética destas quedas irá muito além da escolha de vilões e traidores, não se contentará em execrar os líderes ou tampouco elevá-los à condição de mártires, seguindo a falácia militante de converter uma derrota concreta em vitória abstrata. Para que o movimento dialético de ascensão e queda atinja sua plenitude crítica, ele necessariamente precisa se voltar para a própria ideologia. Por isso, numa 
poesia controversa como a de Thiago de Mello, teremos momentos de entrega demasiadamente simplista à causa defendida, hasteando uma confiança pouco convincente em redenções, como ocorre na dedicatória da "Lição de Cordilheira":
A Salvador Allende, o fogo comendo, o sonho cantando. O povo vai fazer o resto.

(MELLO, 1984, p. 341)

Ou avaliações deste período que optam pelo didatismo, se aproximando do prosaísmo dos discursos oficiais da esquerda derrotada:

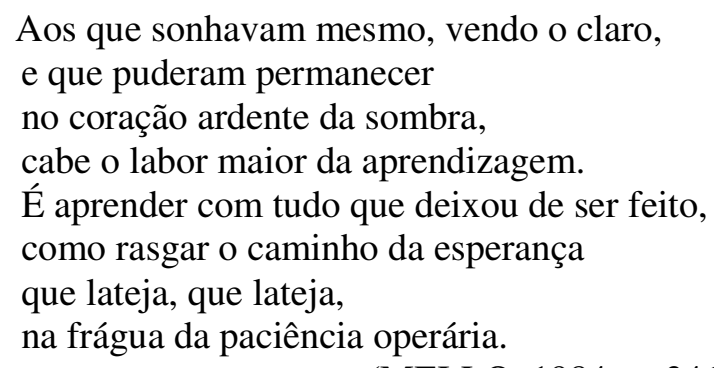

(MELLO, 1984, p. 346)

Em outros momentos, no entanto, o poeta alcança passagens de grande sensibilidade, deixando transparecer, entre as ruínas daquele fatídico setembro, "quando poderia ser a primavera", os caminhos que sua obra - e aqui lembramos do seu esforço em fundir obra e vida num todo coeso e solidário - almeja seguir para além dos acontecimentos políticos-sociais imediatos, isto é, quando a falibilidade da experiência humana oferece sentido, e beleza, à ideologia: pois, como já citamos do poeta, "que avançar neste chão ferido seja/ também saber o que fazer de mim".

Em outros termos, podemos afirmar que a experiência vivida por Thiago de Mello, no período em que cumpriu seu exílio no Chile (entre 1966 até 1973, quando seguiu para Europa), foi de aprofundamento de sua obra na questão social. Sua militância poética tornou-se mais intensa a partir deste período, marcada pela esperança de construção do socialismo no país andino e pela amizade com diversos membro da intelectualidade esquerdista do Chile e do Brasil por lá exilados. O baque sofrido com o golpe militar é tratado com grande interesse pela sua poesia e é visto de maneira ambígua, ora como uma derrota dolorida que expunha os erros da Unión Popular, mas que não chegava a botar em dúvida a validade de suas convicções, ora como um aprendizado necessário, "uma semente que não sabe que abre um rastro de luz na escuridão" (MELLO, 1984, p. 345. 
Obviamente teremos acentuadas neste período as diferenças estrondosas entre $\mathrm{o}$ temperamento poético dócil e cúmplice, característico de Thiago de Mello, e a poética vertiginosa e visceral de Ferreira Gullar. Como tratamos no início deste tópico, o exílio de Gullar mostrou-se particularmente degradante; assombrado pela saudade da família, longe dos amigos, gradativamente descrente da forma radical como entregara sua poesia, anos antes, ao utilitarismo político, Gullar acabou por incorrer num mergulho alucinado na memória da infância.

Ao narrar, em Rabo de Foguete, sua conturbada saída do Chile, sob o risco mortal de cair nas mãos do governo, aquela altura provisório, de Pinochet, a ênfase do narrador recai na aflição e no ressentimento, sem qualquer espécie de afinidade com o Chile que estava prestes a deixar: "tinha que sair daquele maldito país antes que fosse tarde demais" (GULLAR, 1998, p. 185). O exato oposto das representações do Chile na obra de Thiago de Mello, sempre marcadas pela camaradagem, a beleza das cordilheiras e a luta eufórica pelas mudanças em marcha.

Na poesia de Gullar, a queda de Allende é vista de uma perspectiva prioritariamente pessoal: no dia do golpe, Gullar tivera a entrada de sua residência pintada com a palavra "comunista", como um sinal de que os vizinhos conheciam sua atuação, o que significava grandes riscos devido a sangrenta “caça as bruxas" realizada pelas forças militares golpistas, prontas para arrasar os simpatizantes do socialismo upista. O temor de ser denunciado é a tônica de seus poemas, com passagens de discurso ágil e desconcertante, encadeadas no limiar da expressão, verbalizando o pânico da existência ameaçada:

Ao nível do fogo entre fogos (em Santiago do Chile, em Buenos Aires, em) falo

à beira da morte como os vegetais com seu motor de água como as aves movidas a vento, como a noite (ou a esperança) com suas hélices de hidrogênio

(GULLAR, 2009, p. 228-229)

Esta presença constante da morte rondando o poeta que escreve, na ânsia de se exprimir por completo antes da extinção iminente, está no gérmen de todo o Poema Sujo, conforme veremos a 
seguir. Ameaçado por todos os lados, no cerne da tensão social vivida no Chile, Gullar observa os impasses históricos de um dos centros mais importantes da América Latina. Sua cartografia poética demarca um ângulo pelo qual os acontecimentos políticos, as convicções, a revolução, tornam-se impulsos externos filtrados, ou melhor, vitalmente absorvidos pelo sujeito preso ao seu tempo e a sua condição de exilado.

Ainda em Rabo de Foguete, Ferreira Gullar analisará as lembranças do golpe militar chileno de maneira severa. A derrocada do governo, assim como para Thiago de Mello, gerará uma necessidade de reflexão sobre a própria ideologia. Apesar de acompanhar de longe as aventuras do governo socialista, mais como um refugiado do que como um intelectual atrelado ao projeto de Allende, Gullar é quem fará as avaliações mais duras daquele período de intensa mobilização:

Contrário à escolha da via armada para chegar ao poder, eu testemunhara no Chile o fracasso da via pacífica. Que conclusão devia tirar daí? Que não havia como chegarmos ao poder, que a revolução era inviável? Já antes, diante das dificuldades enfrentadas por Allende para fazer a avançar o processo socialista, me perguntara se nós, comunistas brasileiros, devíamos continuar a pagar preço tão alto para chegar ao poder, uma vez que chegar a ele não significava dar melhores condições de vida ao povo e sim, em vez disso, a curto prazo pelo menos, empurrar a sociedade para uma luta fratricida de resultado imprevisível. Agora eu conhecia o resultado: a derrota. (GULLAR, 1998, p. 198-199)

O discurso deste Gullar-narrador que conta suas lembranças do exílio, já no final dos anos 90, aponta o testemunho do golpe chileno como uma passagem fundamental para justificar seu desencanto com o ideário marxista. A fragilidade do governo de Allende, seus erros sintomáticos, a falta de coesão do operariado para organizar uma resistência (queixa também presente no poema de Thiago) foram elementos organizados em Rabo de Foguete como a justificativa histórica e biográfica para que o poeta abandonasse a militância e se afastasse gradativamente dos ideais socialistas, até renegá-los por completo.

Relembramos, entretanto, que a leitura das memórias deve ser conduzida com os cuidados indispensáveis para se analisar este gênero literário. Estamos diante de uma versão dos acontecimentos narrados; o simples fato de estar presente como testemunha dos acontecimentos não confere um valor de verdade ao relato. Ao comentar as particularidades do livro, David Arrigucci diz que "não prevalece, como se poderia esperar, a perspectiva de quem escreve depois que as coisas já se deram e a história, sabida de todos, já é outra” (ARRIGUCCI, 1998). A constatação, todavia, deve ser aplicada basicamente à estratégia narrativa utilizada pelo escritor Ferreira Gullar 
na elaboração do livro. A construção textual coloca em primeiro plano o olhar do sujeito no centro dos acontecimentos, transformando-o num personagem e dando profundidade literária ao livro, que certamente revela cuidados narrativos que vão além do mero relato autobiográfico. Entretanto, transposta para fora do campo dos procedimentos formais, a crença de que o livro, de fato, recupera com precisão as impressões do autor no período ali abarcado, só poderia soar como farsa. Tampouco podemos perder de vista que o próprio gesto de lembrar, a memória em si, é virtual e falível, como nos mostram vários dos ensaios de Walter Benjamin (1996); acompanha as mudanças da visão de mundo do autor, podendo, é claro, alterar as percepções do passado, por comodidade e, às vezes, involuntariamente.

É importante insistirmos nestas considerações antes de passarmos para a leitura de "Dois poemas chilenos", presentes também em Dentro da Noite Veloz e escritos no calor dos acontecimentos. A interpretação nele presente é menos negativa do que aquela concebida posteriormente na escritura das memórias. A segunda parte do poema apresenta vários elementos de uma elegia; o poema se dirige a Allende e é solidário à derrota de seu governo, compartilhando uma tristeza derivada da derrota moral e política provocada pelo golpe. Allende é chamado de "amigo", a expressão é repetida três vezes, destacada entre vírgulas, numa posição que pode ser tanto a de vocativo como a de aposto. A cidade é, na primeira parte, desenhada sob o signo da hostilidade: ao chegar "em plena revolução", o sujeito se depara com um ambiente farto de conflitos. A escrita da memória penetra o discurso poética, dando-lhe ambiguidade e gerando comoção; a descrição contextual do espaço ("em Santiago"), do tempo ("em maio", "o outono") e da situação ("em plena revolução") cria uma atmosfera em que os acontecimentos biográficos e históricos são explorados habilmente pela voz poética. Como mostra a leitura do poema:

\section{Dois poemas chilenos}

\section{I}

Quando cheguei a Santiago o outono fugia pelas alamedas

feito um ladrão

Latifúndios com nome de gente, famílias com nome de empresas também fugiam

com dólares e dolores no coração 
Quando cheguei ao Santiago em maio

Em plena revolução

II

\begin{abstract}
Allende, em tua cidade
ouço cantar esta manhã os passarinhos

da primavera que chega.

Mas tu, amigo, já não os pode escutar.

Em minha porta, os fascistas

pintaram uma cruz de advertência.

E tu, amigo, já não a podes apagar.

No horizonte gorjeiam

esta manhã as metralhadoras

da tirania que chega

para nos matar

E tu, amigo,

já nem as pode escutar.
\end{abstract}

(GULLAR, 2009, p. 226)

A cadência do poema é marcada por uma aparente simplicidade, sobretudo pelas rimas "pobres”, na primeira parte em “-ão" ("ladrão", "coração", "revolução”) e na segunda em "-ar" ("escutar", "apagar", "matar”), mas se estrutura em vários e elaborados jogos de tensões. A principal delas consiste na relação assimétrica que o poema estabelece entre as estações do ano. Na primeira parte, o sujeito chega ao Chile em pleno outono, encontrando um tecido social altamente complexo. A segunda parte se refere ao início da primavera, momento em que o golpe militar se efetivou, culminando no assassinato de Salvador Allende. As metáforas sobre a primavera, aliás, são abundantes na literatura interessada na história do golpe chileno, sempre invertendo o valor positivo desta estação, celebrada na tradição como símbolo de renovação, de beleza e fecundidade, com o intuito de esvaziar seu potencial utópico e denunciar a violência do golpe. A imagem de uma primavera esvaziada, ilusória, foi visitada por Thiago de Mello em passagem já mencionada, quando, ao meditar sobre a derrota de Allende, marca sua situação enunciativa de um tempo sonhado, simbólico e de esvaziada utopia, "quando podia ser a primavera" (MELLO, 984, p. 350), como se o golpe houvesse freado a marcha da história e a primavera estivesse suspensa.

Outras oposições estão espalhadas pelo poema: a chegada do poeta ao país coincide com a fuga em massa da burguesia chilena, com seus "dólares e dolores". O trocadilho expõe as relações dramáticas entre a defesa do capital e os sentimentos gerados pela fuga dos abastados; a 
proximidade entre as palavras "dólares" e "dolores" (que pode ser tanto nome de mulher como a palavra em espanhol para "dor") é semântica e sonoramente implodida por conta da posição que ocupam do poema, formando um abismo rítmico entre a proparoxítona "dólares" e a paroxítona “dolores". A melodia idílica do cantos dos pássaros e o "gorjeio" estridente das metralhadoras também formam um par em constante tensão, assim como a figura fraterna de Allende, repleta de confiança, pelo uso íntimo do sobrenome, e os fascistas que atacam a casa do sujeito lírico e ecoam nos versos finais na imagem ameaçadora da tirania que chega para matar.

O verso é literal: "a tirania que chega para nos matar", nele está presente o tom de pânico que, como foi dito a pouco, faz desta fase da poesia de Gullar uma espécie de canto dos cisnes contínuo, com cada poema sendo uma vitória, limitada e provisória, sobre a opressão que o perseguia em todas as partes. Em uma leitura mais detalhada do poema, Cris Gutkoski (2007) identifica um intertexto do poema de Gullar com a "Canção do exílio", de Gonçalves Dias, textualizado nos versos "No horizonte gorjeiam/ esta manhã as metralhadoras".

O famoso refrão "As aves que aqui gorjeiam não gorjeiam como lá” seria atualizado para o contexto das ditaduras latino-americanas. Assim, a voz idealista de quem se ressente, saudosamente, de estar longe de seu país e que faz ouvir o canto do sabiá como símbolo desta identidade, é rasurada pela violência das metralhadoras, que assassinam o líder chileno e ameaçam o sujeito que, longe do seu país, é impossibilitado de regressar. Desse modo, a chave propiciada pela ressonância dos versos românticos de Gonçalves Dias intensifica a marca elegíaca do poema, pois: "nem o substantivo exílio nem o verbo exilar-se aparecem graficamente, mas o sujeito exilado pulsa em cada segmento do poema" (GUTKOSKI, 2007, p. 8)

Como se pode ver, a voz lírica demonstra afinidade e identificação com o presidente assassinado: ambos são apresentados como vítimas da tirania, há uma convergência entre a morte de Allende e a cruz de advertência pintada na porta da casa onde o sujeito residia. Não há críticas ao comportamento do governo como as que apareceriam de modo severo no livro de memórias; tampouco há heroísmo. Allende é a própria imagem do fracasso, morto, já não pode dar continuidade ao seu projeto; não pode sequer ouviu o ricochetear das metralhadoras que, como pássaros de uma primavera abortada, marcam o cortejo violento dos sonhos ali semeados. 


\section{3- O Poema Sujo e a São Luís latino-americana}

Consumado o golpe militar no Chile, Ferreira Gullar retorna à condição de alvo em potencial de um governo autoritário latino-americano. A perseguição aos intelectuais asilados no Chile, sobretudo os de vocação esquerdista, é imediata, com uma violência impressionante mesmo para a tirânica tradição de ditadores que a América Latina apresentou durante o período da Guerra Fria. Cair nas mãos da ditadura chilena seria um passe certo para a tortura, uma sentença praticamente mortal, exacerbando os temores que Gullar apresentava desde a sua chegada no país andino e que após a derrocada de Allende assumiam uma dramaticidade extrema.

Prevenindo uma eventual investida reacionária, o poeta, assim que chegou a Santiago, se filiou como periodista de um jornal chileno conservador. A medida acabaria mostrando-se providencial no momento de conseguir o salvo conduto para deixar o país, rumo a Buenos Aires. As diversas nuances da fuga, o pavor diante dos rumores de que o governo chileno trabalhava em cooperação com a ditadura brasileira, os obstáculos, a revista da polícia política ao seu apartamento, os riscos incalculáveis da fuga, o cansaço e, por fim, o alívio provisório com a decolagem do avião em que partiria para um lugar mais seguro, estão impecavelmente narrados em Rabo de Foguete, com toda a dimensão trágica que o exílio ganha nas rememorações do poeta. Os capítulos centrais do livro de memórias narram a dramaticidade de uma jornada pessoal pelos acontecimentos políticos da América Latina, sob o olhar de quem testemunhou os eventos mais importantes daquele período de lutas decisivas, acompanhando a saga do autor pelas aventuras e desventuras da esquerda num momento chave da política do continente. ${ }^{57}$

De Santiago, Gullar seguiu para Argentina. Depois, a pedido dos filhos, passaria algum tempo em Lima, no Peru, para onde sua família também seguiu na tentativa de amenizar o sofrimento decorrente do exílio. Esta etapa é marcada pelos problemas com os filhos, envolvidos com drogas e começando a apresentar sérios distúrbios psiquiátricos. Acabam retornando para Buenos Aires, onde a instabilidade política, seguida pela queda de Perón - outro golpe

57 Eleonora Camenietzki, em livro já citado, resume com exatidão a marcha épica das passagens do exílio de Gullar: "A história narrada/vivida por Ferreira Gullar possui todos os ingredientes de um grande romance. Um homem comum, levado por circunstâncias que não controla, se vê no olho do furacão de uma crise política de proporções internacionais. Lançado no mundo, sem saber até quando e como sobreviveria, este homem conhece um grande amor, mas a vida o impedirá de vivê-lo. Empurrado pelas sucessivas derrotas e acumulando perdas e padecimentos de vários tipos, ele encara a morte e escreve seu poema final. A poesia o salva e ele retorna ao seu país, para se deitar nas areias da praia Ipanema". (2006, p. 128). 
testemunhado pelo poeta - e as sucessivas fugas do filho esquizofrênico, culminam no desespero extremo, degradante, que dará o tom de seu livro mais lido, aquele com o qual o autor alcança sua verdadeira consagração, o Poema Sujo:

O poema ia ter por volta de cem páginas, que teria vários movimentos como uma sinfonia e que se chamaria Poema Sujo. Hoje, ao refletir sobre aqueles momentos, estou certo de que o poema me salvou: quando a vida parecia não ter sentido e todas as perspectivas estavam fechadas, inventei, através dele, um outro destino. (CADERNOS, 1998, p. 125)

O contexto de elaboração do longo poema é bastante conhecido e narrado, sugestivamente, pelo autor em dezenas de entrevistas. Exausto por tanto procurar o filho, desaparecido há dois meses pelas ruas de Buenos Aires, desiludido por trotes, pistas falsas, desencontros, num país hostil e em estado de constante - e ameaçadora - agitação política, o poeta decide se sentar na cadeira de seu escritório e "vomitar" sobre o papel toda a flama vital que lhe restava, arrancando um poema da “garganta da linguagem”, no "mais fundo que a memória podia alcançar" (GULLAR, 1977). Tratase de um ato libertador, de quem se sente às vésperas da desistência final e, por que não, às vistas com a própria morte.

Ao instante de revelação, no qual escreve as cinco primeiras páginas, concebidas como uma espécie de canto dos cisnes retirado do âmago do poeta exilado e que pressente o fim eminente, inicia-se um fértil período de criação intensa até que, concluído, o poema é levado ao Rio de Janeiro numa fita cassete com a declamação do próprio Gullar, nas mãos do amigo Vinícius de Moraes, o primeiro grande entusiasta deste que, nas palavras felizes de Alcides Villaça, é um vigoroso "discurso poético autobiográfico de grande fôlego" (VILLAÇA, 1984, p. 145). Lançado em livro, torna-se a obra mais comentada nos salões literários e, pela sua intensidade e ousadia, é coroada - dentro da ainda altissonante polêmica em torno do concretismo - como a definitiva refutação dos que pregavam a morte do verso.

O longo poema é formado por vários movimentos encadeados no decorrer de um tenso processo de rememoração. Cada uma das cenas ganha os contornos da infância, em larga medida composta com elementos biográficos que serão explorados num discurso literário denso, provocante, visceral. O núcleo do poema é a São Luís onde o poeta cresceu. A cidade natal surge como espaço da fome, alvo da denúncia social latente no poema, mas é também o espaço afetivo relembrado pelo sujeito em sua maturidade trágica, do homem exilado, cuja vida pode ser a 
qualquer instante cessada por um agente da repressão que lhe arrebenta a porta. A ênfase na memória explica o ritmo fragmentário, com vários quadros partidos em estilhaços que se complementam precariamente. Os acontecimentos saltam vertiginosamente no papel sem uma cronologia explicitada, marcando a fugacidade das lembranças adulteradas, sabidamente perdidas, embaralhadas numa sinfonia irregular, carregada de associações livres e variações rítmicas. Lembranças inalcançáveis mesmo enquanto recordações precisas, mas que num instante extremo precisam ser lançadas para fora através do peso deformador da linguagem, único canal em que podem aspirar uma duração que ultrapasse o sujeito que as gerou, ainda que esta duração, por estar limitada à linguagem, seja conscientemente restrita.

Sem nos alongarmos muito na avaliação e exame de obra tão complexa e alvo de análises minuciosas, como as de Alcides Villaça (1999), ou exclusivas como as de Vinícius de Moraes (1977) e Beth Brait (1981), partiremos de imediato para a questão que nos interessa e que busca marcar nossa contribuição para o debate de uma faceta pouco comentada pelos estudos mais consagrados. O que colocamos em evidência nesta discussão é a forma como a voz lírica estabelece uma ponte enunciativa entre a cidade natal, guardada na instabilidade da memória, e a cidade do exílio - o exato oposto da afetividade natal - que contempla pela janela de seu quarto, em Buenos Aires. Mais que isso: queremos entender como estes dois cenários distintos, ocupando os extremos da afetividade do sujeito, convergem para a composição de um espaço comum que os interliga numa condição latino-americana.

A constatação de que a São Luís evocada pela voz lírica é, dentre uma série de outras abordagens possíveis e complementares, uma típica cidade da América Latina está literalmente enunciada mais de uma vez ao longo do Poema Sujo, como na seguinte passagem:

enquanto como um rato

tu podes ouvir e ver

de teu buraco

como essas vozes batem nas paredes do pátio vazio

na armação de ferro onde seca uma parreira

entre arames

de tarde

numa pequena cidade latino-americana.

(GULLAR, 2009, p. 288-289)

A definição da São Luís do poema como uma "pequena cidade latino-americana" ocorre 
num estágio adiantado do livro, nas suas últimas páginas. Até então ela é velada, sugerida ao leitor nos vários núcleos narrativos que compõem a obra. $\mathrm{Na}$ visualização da estrofe transcrita, é fácil notar que o recuo coloca em destaque o verso no qual a cidade da infância revela-se como "latinoamericana". Não há dúvida de que o poeta nos apresenta, quase como numa revelação, a lição de que a cidade onde nasceu e cresceu está contida em outras unidades aglutinadoras, de natureza histórica, econômica e social. Ou seja, assim como "muitos dias há num dia só" ou como "numa noite há muitas noites" ou ainda "a tarde tem muitas velocidades", nesse jogo simultâneo e impuro em que tudo está contido em todas as coisas, dialeticamente, como se o poeta buscasse imprimir na tessitura do papel "uma totalidade fundada no movimento e na diversidade" (CAMENIETZKI, 2006, p. 137), deste mesmo modo, a cidade lembrada, sob a ótica do sujeito que reconstrói através da linguagem um passado incontornável, possui vários níveis que se chocam e se complementam. É a pequena cidade provinciana dos anos 30, brasileira, latino-americana, terceiro-mundista e cósmica, como um ponto aleatório do universo, onde calhou de alguém visualizar, comovido, o solene silêncio das estrelas.

Antes e depois do Poema Sujo, Gullar já manejava com destreza o recurso de inserção múltipla do espaço tematizado - neste caso a cidade natal - em figurações espaciais mais amplas, sobrepostas umas às outras. Em muitos casos, este desejo de totalidade, obsessão em dizer tudo, ao mesmo tempo - como já nos explicou Alcides Villaça (1984) ao falar do recurso da sincronização passa por imagens cósmicas, flutuantes no silêncio absoluto, por cenários pessoais, subjetivados, até alcançarem a paisagem histórica, o tempo humano, material e limitado. O manejo deste procedimento literário caro a Ferreira Gullar pode ser visto nas seguintes passagens $\frac{58}{}$ :

(No nosso desamparo de São Luís do Maranhão na Gamboa dentro do sistema solar entre constelações que da janela víamos num relance)

(GULLAR, 2009, p. 219)

Júpiter, Saturno.

58 Em seu livro mais recente, Em Alguma Parte Alguma (2010), há um capítulo dedicado a estes "estudos cósmicos”. Nele estão reunidos poemas que refletem o fascínio do poeta pelos astros, pelas grandes dimensões do infinito celeste, e a indiferença deste silêncio inalcançável para com os dramas humanos. $\mathrm{O}$ estudo de Alfredo Bosi, "Roteiro do poeta Ferreira Gullar" (2004) e o prefácio que o crítico escreve para o livro Em Alguma Parte Alguma oferecem as interpretações mais agudas sobre a presença do cosmo na poesia do autor maranhense, relacionando-a com o caniço pensante de Pascal. 
de dentro do meu corpo

estou vendo

o universo noturno.

(GULLAR, 2009, p. 193)

\author{
Neste divã recostado \\ à tarde \\ num canto do sistema solar \\ em Buenos Aires
}

(GULLAR, 2009, p 302)

Nota-se, nestas passagens, um intrincado e habilidoso jogo de cenários encadeados, onde um espaço compõe vários espaços simultaneamente e as grandes dimensões do cosmo revelam a fragilidade, o desamparo do sujeito e a relativização da história humana. O expediente reforça a busca do homem por um sentido diante do infinito celeste, ao mesmo tempo em que precisa atuar na realidade mais imediata, pois vê a fome, a injusta distribuição de riqueza e sente o cheiro fétido do rio da infância ou descobre o frio da noite proletária.

O infinito cósmico é esvaziado de qualquer misticismo; ele não responde aos questionamentos, não acolhe nem ofusca a concretude do sujeito profundamente preso na cidade. Não obstante, sua mudez é eloquente: revela a fugacidade da vida, o efêmero dos afetos, o anonimato da grande cidade e a necessidade - não há outra escolha - de participar criticamente do ruidoso espetáculo da convivência e das lutas cotidianas. São pequenos choques, flashes, em que "ao falar do finito, o olhar do poeta se depara com o infinito e o corpo-texto se arrisca no universo" (CAMENIETZKI, 2006, p. 141).

A tensão surge do atrito semântico entre as palavras que acenam para a grandeza cósmica, muitas vezes explorando de forma hiperbólica o vocabulário técnico da astronomia, com as situações do cotidiano, dos sofrimentos humanos que são os grandes temas da poesia de Gullar. No embate do "homem comum" com o universo, coexistem múltiplas formas temporais que se intercruzam e se interpenetram na lógica do poema: o tempo histórico, o tempo subjetivo do sujeito que agrupa estilhaços da infância, o tempo durativo do leite que vira coalhada ou da pera que apodrece na mesa diante do mar, o tempo imensurável dos astros e por aí vai.

Neste inquieto mosaico de lugares díspares e sincronicamente moldados pelo desejo totalizante do poeta, a presença da América Latina é comum e bastante pertinente. Assim como a cidade da infância, com seus problemas resgatados pelo olhar maduro do sujeito que a recorda num 
momento extremo - esta "pequena cidade latino-americana" - outros poemas determinam esta identificação solidária do espaço sensível tomado pelo poeta com uma noção mais ampla - política e ideológica - de uma América que compartilha mazelas, soluções e estratégias de atuação semelhantes. Deste modo, não é apenas a cidade da infância que emerge na poesia de Gullar como uma exemplar cidade latina, em outros poemas este sentido amalgamado exerce a mesma função ${ }^{\underline{59}}$ :

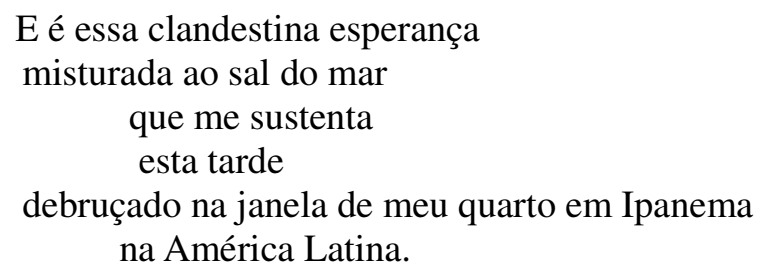

(GULLAR, 2009, p. 181)

Ao restabelecer poeticamente a "São Luíz quente e realíssima" (BOSI, 2004) do passado, com a miséria das ruas, a exploração generalizada, a sensualidade intensa, Gullar o faz com o olhar do presente, com a angústia do exilado e a sensibilidade de quem, assim como sabe que toda reconstituição do passado é imprecisa, mantém a consciência de que a vitalidade dos vários quadros que compõe a cidade onde nasceu alcançam uma abrangência sócio-histórica mais ampla que a da simples identificação autobiográfica. Desse modo, temos dois pontos de vista que se alternam livremente de tal forma que:

coexistem dois sujeitos no Poema Sujo: o primeiro, colado à imanência dos fatos passados, fornece uma história captada pelos limites do corpo, história impressiva e viva do que já houve; o segundo, instalado no presente da elaboração poética, reflete e interpreta esse passado. (VILLAÇA, 1984, p. 154)

Qualificando ainda mais a deixa proporcionada por Alcides Villaça, podemos afirmar que este primeiro sujeito, o que vive as situações rememoradas no decorrer do poema, apresenta o olhar próprio da criança, sem acesso aos desdobramentos do futuro, vendo na pequena cidade uma realidade autônoma e completa; ao passo que o olhar "maduro", do exilado político, é aquele que termina o poema com a inscrição (Buenos Aires, maio/outubro, 1975) e que assinala em várias partes do poema a cena de escrita: "meu sangue feito de gases que aspiro/ dos céus da cidade estrangeira" (GULLAR, 2009, p. 238) . Em outra passagem exemplar, o poeta parte do jogo

59 Vale a pena observar também o poema "Por você por mim", de Dentro da Noite Veloz. Nele o cruzamento se dá entre a guerra do Vietnã, com os tiros e mortes, e uma pacata tarde de Botafogo, bairro carioca elitizado. A violência do conflito e a aparente calmaria do bairro, com seus homens sérios e engravatados seguindo para o trabalho, se aproximam numa ligação tensamente articulada pelo poema. 
dialético entre dentro x fora, tônica do poema que, para Villaça, é a própria "sujeira" do título, constitutiva de tudo que existe, e marca sua condição de exílio, no momento presente, com seu espaço e tempo característico:

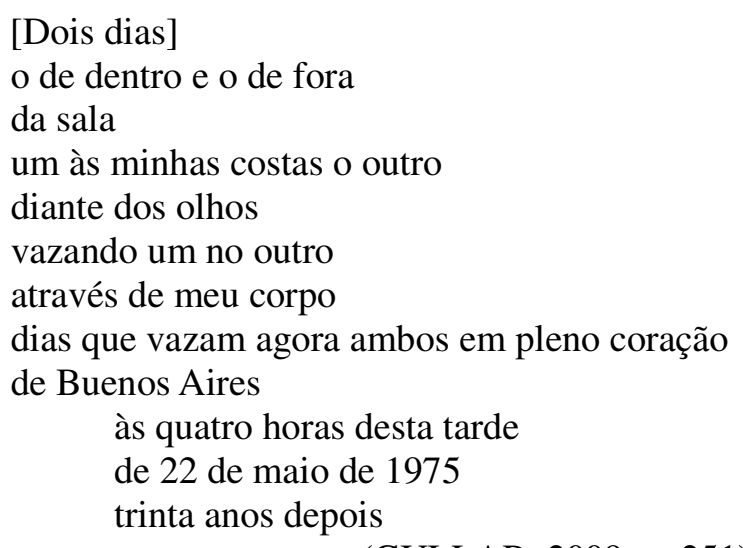

(GULLAR, 2009, p. 251)

Ou de maneira extremamente lírica e bela no desfecho, que é a também síntese do poema: a cidade está no homem
quase como a árvore voa
no pássaro que a deixa.

(GULLAR, 2009, p. 290)

É possível que a força do drama existencial resultante do mergulho nas memórias da infância, tão comovente no Poema Sujo, tenha afastado dos estudos do livro outras vertentes importantes da obra. Apoiadas inclusive na revisão que o poeta faz posteriormente de sua obra - um Gullar imerso em novos campos intelectuais, mais próximo aos grupos hegemônicos e exibindo um desencanto confesso em relação ao socialismo - várias leituras reforçam a ênfase na reflexão existencial em detrimento ao ímpeto participante. Concordamos que o grande trunfo do Poema Sujo é justamente a fusão mais condensada do drama histórico ao aprofundamento da subjetividade do sujeito poético. Sendo assim, o eu do poema ganha contornos mais complexos, passando a contemplar em sua expressão a dor do exilado, a especulação de quem rememora a infância e assume como falível, embora necessária, toda ação política.

Ele, porém, não perde de vista, com esse alargamento, o ethos de militante revolucionário que, ainda que envergonhe o poeta de hoje, faz do livro uma inquestionável continuação da voz que já se organizava em Dentro da Noite Veloz. Para tanto, basta vermos alguns trechos em que a confiança no projeto revolucionário, a identidade militante, revolucionária, ainda que enriquecida 
por um fio de dúvida, crítico das certezas programáticas, permanece intensa:

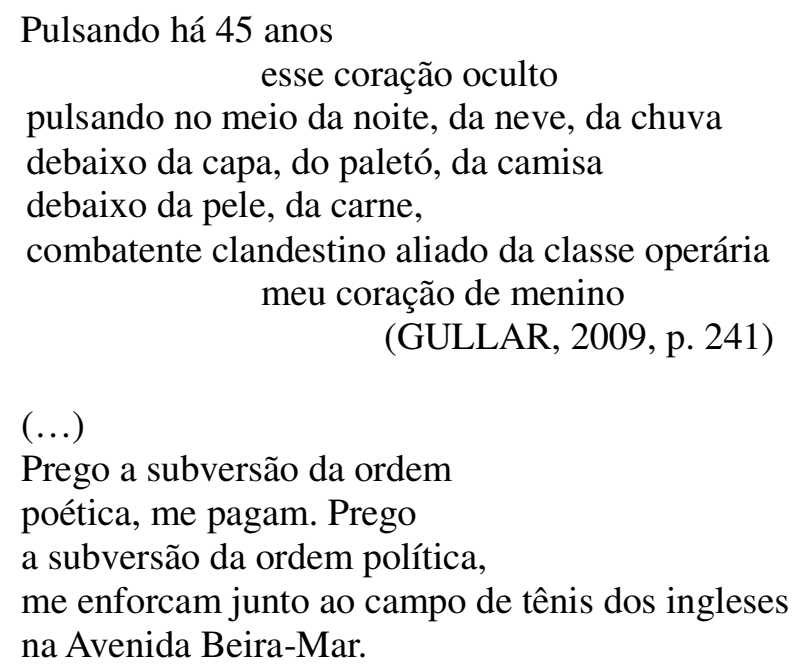

(GULLAR, 2009, p. 279)

A fundamentação do Poema Sujo, como temos lido, passa, além da estruturação decorrente das lembranças do sujeito privado de sua pátria, pela denúncia presente nos vários quadros que se formam a partir deste vertiginoso passeio pela São Luís da infância contemplada por uma turva janela da Buenos Aires pelo homem maduro e infeliz. Dentro deste microcosmo íntimo, o poeta faz brotar um infindável painel social que vai muito além da descrição do espaço natal e dos personagens que nele se movimentam, para organizar uma densa representação do contexto político brasileiro, no qual, de acordo com João Luiz Lafetá:

A procura de si mesmo (que é o primeiro nível do texto) se dá dentro de uma realidade cultural (os hábitos de vida em São Luís do Maranhão) e acaba por nos oferecer a imagem de pelo menos uma parcela da sociedade brasileira. Ou seja: a identidade pessoal revela-se como uma identidade cultural, inserida dentro de uma mais ampla identidade nacional. (LAFETÀ, 2007a, p. 207)

Para completar o raciocínio de Lafetá, cumpre notar que a São Luís tropical, desigual e rodeada de afetos perdidos, torna-se também, além de concretização lírica do "regional", do "nacional" e do "subjetivo/mnemônico", um manancial concreto e coerente da condição terceiromundista. Esse plano é dado pelo presente da enunciação, com as pistas que o sujeito exilado deixa como feridas da lembrança. Enquanto vítima de um movimento historicamente determinado, este sujeito que enuncia cria uma camada de sentidos que está em consonância com a angústia do exílio, que está em choque constante com o conforto (precário) do lar natal oferecido pela lembrança.

Esta vertente se fortalece pela escolha enunciativa de um ponto de vista latino-americano: o 
contexto da segunda guerra mundial, muito forte no livro, é visto de longe, os sentimentos que ele desperta são decorrentes das notícias ouvidas no noticiário, ou ainda o pressentimento da modernidade que passa pelos ares, indiferente, junto ao avião norte-americano que cruza o céu de São Luís.

Além disso, temas clássicos do debate político da esquerda latino-americano marcam presença no poema, como a exploração das classes mais pobres ("mínimo salário que essa gente recebe"; "não os sustém o banco/ e sim o trabalho não pago"), a dependência econômica de viés imperialista, com suas multinacionais e marcas sedutoras ("chegaram os americanos/ para construir a base aérea do Tirirical/ compraram todas as frutas e legumes/ do Mercado.”), o latifúndio e a hipocrisia da sociedade patriarcal ("Neco matou a mulher/ que - dizem - lhe punha chifres"), dentre várias outras de nossas mazelas sociais cintilando não mais de forma pedagógica, impostas pela missão revolucionária que os poetas adeptos do engajamento literário frequentemente imprimiam em seus livros, mas como camadas indissociáveis dos quadros, épicos e líricos, construídas no poema, num enlace fecundo entre o sofrimento individual, a reflexão histórica e a crítica social.

\section{4- Thiago de Mello: a língua do exílio e a língua do diálogo}

Outro ponto que merece ser examinado com atenção ao se retomar criticamente a vertente americanista dos anos 60 e 70 é o papel da língua no âmbito do diálogo continental. Ao longo dos anos, a questão do idioma tem se mostrado historicamente como um dos obstáculos mais sólidos para o aprofundamento das relações entre o Brasil e a América hispânica. Única nação dentro do continente a adotar o português como língua oficial, o país muitas vezes é deslocado para uma posição secundária dentro dos anseios comunitários, como se a língua, canal basilar do diálogo, se erguesse ironicamente como uma barreira para o contato mais profundo entre as nações.

O obstáculo seria menos tortuoso se se restringisse apenas ao aspecto comunicativo mais imediato - o dizer e ser entendido, o ouvir e compreender o outro, simples conversão de signos entre falantes -, porém sabemos que a língua traz consigo toda uma história particular, uma tradição de usos e referências; o pensamento humano não pode existir sem uma língua que o expresse e, pela sua própria condição histórica interna, a língua invariavelmente delimita ou expande essa 
expressão, pois a antecede (DIAS, 1996). Seu uso por uma comunidade de falantes pressupõe sofisticadas redes de compartilhamento de experiências delicadamente associadas a uma visão de mundo específica. Portanto, mais do que não entender a fala do outro, a diferença do idioma gera uma série de nuances que interferem nas práticas culturais dos países em questão.

Além desse desencontro de origem entre a formação histórica através da língua, devemos considerar também dois aspectos mais concretos que não podem ser negligenciados ao se pensar numa visão comunitarista de base latino-americana fomentada a partir da literatura: 1) os sistemas literários em jogo, tal como conceituados tradicionalmente por várias tendências acadêmicas ${ }^{60}$, são distintos; isto é, partimos de uma visão consagrada que separa as literaturas hispano-americanas, escrita em língua espanhola, da literatura brasileira, inserida no bojo das literaturas de língua portuguesa, criando uma desvinculação das criações brasileiras com as obras dos países vizinhos, cisão que é sustentada por parte considerável dos estudos literários e reproduzida na educação básica e nas universidades; 2) a diferença na língua dificulta a circulação de repertórios culturais, visto que a necessidade de traduções - inexistente na circulação entre os outros países latinoamericanos - gera barreiras comerciais e artísticas para um cruzamento mais intenso de obras entre o Brasil e os países hispânicos.

Fixando outra vez nosso olhar no contexto de euforia dos anos 60 e 70, é possível perceber nas obras do período uma tendência generalizada em se subestimar a barreira do idioma para a inserção do Brasil na ideia de América Latina então vinculada por nossos artistas. No âmbito teórico e político, se sobressaia, como já foi dito algumas vezes no decorrer do trabalho, a ênfase na condição social do povo latino-americano, na dependência econômica, na presença incômoda das garras imperialistas e do latifúndio, deixando esquecidas em planos secundários as diferenças culturais, inclusive linguística, por trás da busca política pelo (re)conhecimento mútuo.

Para um leitor fincado nos nossos dias, pode soar incômoda a tendência de vários autores a camuflar as diferenças e rebuscar aparentes semelhanças. Isso não pode, contudo, nos levar a tentação de julgar as manifestações do período com os critérios triunfantes apenas muito tempo depois que a aspiração comunitária, americanista e libertária, com todas as suas limitações e contradições, foi parcialmente abafada pelo individualismo neoliberal e globalizante. Mais

60 Para nós, brasileiros, a conceituação de sistema literário é de imediato relacionada ao pensamento de Antonio Candido (1975). Fora do Brasil,, Angel Rama (2006) é outro que, em diálogo com a obra do crítico paulista, difunde uma noção semelhante aplicada à história da literatura hispano-americana. 
produtivo nos parece acompanhar alguns resquícios da inquietude que, por dentro das camadas de otimismo militante, ressoam nas obras como intuição das divergências, dos paralelismos que, animadores à primeira vista, ressurgem inconciliáveis mais adiante.

Ao optarmos por este caminho, nos deparamos com a imagem da língua como elemento paradoxalmente anti-comunicativo, uma nova Babel delineando as fronteiras do Brasil e reafirmando sua condição insular: um país separado, pela imensidão do oceano Atlântico, da antiga metrópole da qual herdou o idioma, e simbolicamente desmembrado da geografia latino-americana pelo rígido muro da língua. Desse modo, é como tema secundário, despretensioso, marcado pela abordagem positiva, que alguns artistas acabarão se deparando com este obstáculo e, diante dele, formularão algumas respostas esparsas, mas ocasionalmente incisivas, para os desafios políticos e culturais decorrentes da diferença idiomática.

Na música popular, por exemplo, são abundantes nas chamadas "canções de protesto" dos anos 70 - fortemente interessada na questão do diálogo latino-americano - a tematização formal do problema da língua como a pedra no meio do caminho do almejado diálogo. Os procedimentos adotados para a exposição desta barreira, no caso da música, são vários e interessantes: o impasse do idioma podia ser resolvido harmonicamente, por uma eufórica supressão da dualidade linguística no momento da performance musical, tal como se via nos concertos/comícios em que cantores brasileiros, como Chico Buarque e Milton Nascimento dividiam o palco e a canção com cantores hispânicos como Pablo Milanés, Silvio Rodriguez, Mercedez Sosa ${ }^{61}$, alternando partes cantadas em português, partes em espanhol, como se a música exibisse seu âmago latino-americano através do enlace solidário e erótico das duas línguas, sendo o palco a metonímia da própria América Latina e os cantores símbolos de seus respectivos povos, envolvidos na catarse que a canção provocava. Mas podia ser apresentada, também, de modo festivo, como nas alegorias tropicalistas, sobretudo nas letras e poemas de Capinam, ora fazendo paródia em um poema como "Portunhol" (CAPINAM, 1995, p. 17), ora a bradar, em parceria com Gilberto Gil, o célebre refrão em castellano "Soy loco por ti América", na híbrida canção (tanto na mescla de idioma como na abundância de ritmos latinos) com mesmo título. Poderia, por fim, ser exibida com uma dose de melancolia e

61 O contato da MPB com a Nueva Música argentina e a Nueva Trueva cubana foi fundamental para que a vertente americanista, que neste trabalho estudamos na poesia, encontrasse uma linguagem bastante madura na música popular. Yolandas e Marias passaram a circular intensamente por vários países do continente, criando novos públicos para a música brasileira na medida que a própria música dos países vizinhos também passavam a se tornar familiar para os amantes da MPB, seja nas vozes originais, nas adaptações ou parcerias. 
desconforto, como em uma ou outra letra de Belchior, quando a aceitação da identidade latinoamericana - "um tango argentino me cai bem melhor que um blues" - é seguida do refrão que confessa a difícil comunicação e a angustiante posição do Brasil neste diálogo: "desesperadamente eu grito em português".

Na obra de Ferreira Gullar, o imbróglio em torno do idioma não recebe grande interesse do autor nos poemas em que faz menção a América Latina. A ausência pode ser explicada pela própria noção de identidade desenvolvida no decorrer de sua poesia. Como vimos anteriormente, o poeta afirma uma identidade construída a partir da diferença, ou seja, uma fraternidade racionalizada no presente, retirada do cerne de nossos problemas sociais comuns, sem nenhuma mistificação. Neste sentido, como vimos em "Nós, latino-americanos", pouco vale o sangue, o sobrenome, a filiação e poderíamos acrescentar, sem fugir da sua lógica, a língua. O que nos dá certa unidade é a recorrência fragmentária do mesmo dilema político, da mesma miséria a ser superada, de preferência conjuntamente. Ainda assim, citações em espanhol utilizadas para delimitar um contexto, como no Poema Sujo e em alguns poemas de Dentro da noite veloz, não são de todo ausentes em sua poesia.

Em Thiago de Mello, por sua vez, a questão linguística é frequentemente alvo de investidas do poeta. Trata-se de uma marca robusta do seu esforço americanista. A primeira vista pode parecer até surpreendente que numa poética em que o diálogo latino-americano emerge de maneira afável, num uníssono quase sempre simplificador, seja justamente aquela que, ao nosso ver, desenvolve com maior empenho o questionamento da língua enquanto fator chave para a desejada integração continental. O trânsito entre o português e o espanhol é tão substancial no decorrer de sua produção literária que mesmo sem defender explicitamente uma saída sintética para este dualismo de sistemas e falas - como, aliás, o poeta faz, didaticamente, com várias das facetas de sua militância política podemos defender que há, seguramente, um esforço programático de encurtamento da distância entre os idiomas.

A estratégias discursivas que apontam para este projeto são diversas e, de alguma forma, estão relacionadas a chegada do poeta ao Chile, durante o exílio. É neste período de intensa atividade artística e intelectual que Thiago de Mello aprofunda seu convívio com a língua espanhola, tendo diversos interlocutores, chilenos e de outras nacionalidades, num contato prolongado com figuras de primeira grandeza da literatura hispano-americana. O exílio ao mesmo 
tempo em que aprofunda o fascínio do poeta pela união dos povos americanos também confirma particularidades, gera estranhamentos próprios da condição de quem está longe do lar natal, imerso na experiência degeneradora da perda. Um destes estranhamentos, de certo o mais evidente, está no idioma, o esforço para interagir, agir e criar numa língua diferente da materna.

As comparações entre a paisagem chilena - as cordilheiras, o mar agitado, imagens relacionadas com o contexto político do país - têm como pano de fundo as lembranças de seu Amazonas, com suas águas mansas e vida simples. Assim como no grande poema de Gullar, “Traduzir-se", em que somos apresentados a um sujeito dividido e simultaneamente dialético, pois cada parte está na outra, indistintamente, assim a poesia de Thiago de Mello abre-se para ser parte de dois lugares: ela é a dor do exílio e adaptação, é devota do Chile e de Allende como é saudosa do Amazonas e da pátria brasileira, e, aqui sim alcançando certa originalidade, é comunhão com a língua e os amigos chilenos mas, ao mesmo tempo, é compromisso com a voz simples dos povos ribeirinhos, ecoando em bom português o escuro que o poeta canta de longe.

Há, assim, um projeto que talvez seja a grande marca de sua poesia. Com a voz benévola do cúmplice - este sujeito-amigo que fala em seus poemas - o autor leva adiante a captação da língua espanhola, utilizando-a como recurso expressivo e oferecendo-a aos seus leitores, domada, como um trunfo para o diálogo.

A primeira marca deste programa, podemos ir buscar fora dos seus versos. Thiago de Mello tem sido ao longos dos anos, não apenas um importante poeta, mas também contumaz tradutor de obras em espanhol, basicamente de autores latino-americanos. Desde que estreitou os laços com amigos chilenos, o poeta tornou-se estudioso atento da literatura hispano-americana. Ainda no exílio, traduziu livros de Neruda, e foi por ele traduzido. Com o passar dos anos, seguiu sendo um dos principais tradutores do vate chileno para o português e tornou-se também tradutor da poesia de Cesar Vallejo, Ernesto Cardenal, Nicolás Guillén, dentre outros poetas de prestígio. Durante a elaboração final desta tese, ele publicou uma das mais completas antologias de poetas latinoamericanos, no qual define com exatidão o sentido de seu ofício como tradutor: "Traduzir seus poetas é abrir brechas de luz sonora no muro espesso da incomunicação entre os países desunidos desta América" (MELLO, 2011, p. 18). A obra traz ao público brasileiro mais de 40 autores representativos de praticamente todos os países do continente, muitos deles ainda sem outras traduções e completamente desconhecidos por este público. O ofício de tradutor é apresentado 
como complementar e inseparável da atuação do poeta, como afirma em entrevistas, em poemas, como no interessante "Tradução, verbo e música" (MELLO, 1996, p. 32), ou nos prefácios carregados de lirismo e intimidade que geralmente escreve para os livros que traduz.

A escolha das obras que revela para o português parecem ter como critério principal - assim os discursos em torno das obras indicam - a admiração que nutre pelos poetas traduzidos: ele assume a importância de oferecer ao público brasileiro a obra destes autores, num compromisso pessoal, comunitário e de fundo ético, salientando aquele sentido tão caro à tradução enquanto ativismo cultural, ponte entre duas culturas distintas.

A familiaridade de Thiago de Mello com intelectuais da América Latina constitui um capítulo à parte. A convivência do autor com artistas vai muito além de um aspecto biográfico isolado, ou da batida busca por influências, pois é absorvida pelo seu temperamento poético, por este ethos de seus poemas, e atua no interior de seus livros. É difícil compreender adequadamente a sua poesia sem se deter nas inúmeras homenagens, referências, intertextos que o autor realiza no decorrer dos seus livros mais (e menos) importantes.

É nesta sucessão grandiloquente de amplexos verbais que a obra se reveste da aura de amistoso humanismo, de ternura comprometida, que acaba sendo sua marca registrada. São muitos os prefácios elogiosos que abrem seus livros, sempre carregados de camaradagem e que formam, antes mesmo da leitura dos poemas, uma atmosfera cordial, mais próxima da conversa informal que da experiência estética autônoma, contemplativa.

Como não poderia deixar de ser, muitas das apresentações de seus livros são escritas por intelectuais/amigos latino-americanos. Em Thiago de Mello, mais talvez do que em qualquer outro poeta brasileiro, os prefácios deixam de ser guias críticos para inserção do leitor no estilo do autor, para se converterem em partes inseparáveis da obra. Neste sentido, é curioso perceber que nos casos em que a apresentação do livro é feita por estrangeiros, ela é sempre mantida na língua original, ou seja, em espanhol.

É assim com "Desde que Thiago llegó a Chile", relato de Neruda que abre o livro Faz escuro mas eu canto (1966), ou com o soneto, também de Neruda, que abre De uma vez por todas (1996), ou ainda com "Palabras para Thiago de Mello", escrito pela cubana Nancy Morejón e presente na abertura de Campo de Milagres (1998). Para comprovar a inserção do prefácio como 
artifício de agregação simpática à substância supra-poética dos livros, podemos citar breves passagens destes textos, sublinhando o caráter afetivo, íntimo, que servem muito mais de introdução ao poeta/cidadão, ou ao menos ao ethos que ele cria nos poemas, do que aos procedimentos formais do autor e da obra:

Thiago de Mello es un transformador del alma. De cerca o de lejos, de frente o de perfil, por contacto o transparencia, Thiago há cambiado nuestras vidas, nos há dado la seguridad de la alegría.(...) El tiempo se adhiere a nuestra piel para gastarnos. Thiago pasa por nuestras almas para invitarnos a vivir. (NERUDA, 1966 apud MELLO, 1984, p. 205)

Por Thiago aprendi a amar al Brasil y su vasta cultura y su lengua americana, tan indomable como el cauce que baña la floresta. Por Thiago, ahora mismo, acabo de adentrarme en el mistério de la traducción - de su poesía - y de lo que es más importante aún: la de su ejemplo como el poeta fiel que es a las mejores causas.

(MOREJÓN, 1998 apud MELLO, 1998, p. 9)

Já no interior de sua obra poética propriamente dita, a luta para se buscar uma língua propícia ao diálogo comunitário assumirá formas bastante engenhosas. Uma delas, a mais óbvia, é a publicação de poemas escritos em espanhol. Os "Três poemas em espanhol", criados durante os anos em que viveu no Chile, são reunidos como capítulo do livro A Canção do Amor Armado (1966). A presença de poemas escritos na língua vizinha, divulgados numa edição brasileira, sem qualquer forma de tradução, visa marcar este trânsito do autor pelos dois espaços, Brasil e América Latina, amalgamados em sua voz poética como um só, tal como sugerido pela justaposição dos idiomas em sua obra.

Um procedimento parecido consiste na elaboração de poemas híbridos, mesclando versos em espanhol e versos em português. O efeito é harmonizador, como se pode notar em "No coração da memória, resumo da minha vida", um dos últimos poemas de Poesia Comprometida.... Neste poema os registros se encadeiam livremente, não só o português (que predomina como fio articulador) e o espanhol (também bastante numeroso) mas também, em alguns versos, o italiano e o francês. Tecendo uma síntese da própria vida a partir de um mergulho na memória, o autor percorre os espaços pelos quais passou, as línguas e, principalmente, as obras clássicas que lhe servem de referência. Sobretudo quando forja jogos de palavra com os nomes de livros que lhe 
servem de espelho para atuação literária, a matéria poética torna-se desastrada, pouco consistente, às vezes até causando um riso certamente involuntário. Vemos neste poema meio extravagante, além da audaciosa mistura dos idiomas, o desejo de marcar um sujeito cosmopolita, capaz de compartilhar uma comum cultura humanista $\underline{62}$ :
(...)Já varei
a dor do grande sertão,
veredas que me levaram
à residência na terra. (...)
Duro metal del diablo,
este que arde devorando
meu son entero. Sozinho,
toco uma frauta de barro,
sabendo que sous le Pont
Mirabeau coule la Seine
et nos amous, Sagarana.

(MELLO, 1984, p. 364)

É importante reparar que a mescla linguística não é em momento algum tensionada; não há choque entre os significados contidos em cada uma das sentenças, muito ao contrário, os versos em português e espanhol se complementam limpidamente; a diferença linguística é organizada pacificamente, domadas pelo tom convidativo desta poética, sustentada, enfim, pelo afã amistoso e participativo da voz lírica.

Este fundo pedagógico, obsessão em fundir poesia e vida que, em vários momentos a banaliza, afasta a obra de Thiago de Mello das linhas centrais da poesia brasileira, sobretudo, após a década de 70. O esforço de construção e contenção elevado ao grau máximo de elaboração por João Cabral de Melo Neto, depois radicalizado pela experiência concretista, foi muitas vezes tomado indiscriminadamente como único modelo válido para a criação poética, sendo domesticado e, por fim, banalizados, pelas gerações seguintes. Ao comentar a produção brasileira no início dos anos 90, Iumna Simon tece um painel pessimista dos rumos que nossa poesia esboçava naquele período:

a arte já não precisa sequer se alçar a expressão nova das inquietudes subjetivas ou ser experimental no sentido vanguardista: basta que se alegue competente, que seja bem feita, que demonstre um conhecimento acadêmico da linguagem, "perícia" no

62 Numa dura resenha chamada "Thiago de Mello: os enganos da utopia", o crítico Felipe Fortuna condena como raso o otimismo político presente na vertente universalista do autor: "pretendendo ser cosmopolita, não ultrapassa o esboço de uma luta entre Bem e Mal, de oprimidos e opressores, o que explica, para além da metáfora fácil, a dimensão menor de sua poesia" (FORTUNA, 1986). Delimitando o exame severo do crítico para algumas passagens da obra de Thiago - já que expandindo este julgamento para o conjunto da obra ele pareça um pouco exagerado, ou mesmo injusto - temos realçado o peso de algumas obsessões do autor, às vezes desgastadas pela repetição pouco criteriosa em vários poemas que não chegam a moldar um rosto próprio. 
uso dos recursos, que apresente variedade de técnicas e procedimentos de composição; enfim, basta que saiba revisitar, como se ua dizer hoje, obras e artistas modernos e de todos os tempos, e já terá cumprido seu papel e terá assegurado seu público. (SIMON, 1993, p. 122)

O triunfo desta vertente, marcada pela apropriação a-crítica de cacoetes formais, frequentemente carregados de pedantismo, ajuda a prefigurar o panorama de pouca vitalidade da poesia brasileira atual, no qual os livros de Thiago de Mello, menos por seus desacertos e equívocos evidentes do que pela matriz estética que adota, é dado como vertente superada, anacronicamente utópica, simplista nas ideias que defende e pouco rigorosa na elaboração formal $\underline{\underline{63}}$.

Por isso, é sintomático observar que a abertura de sua poesia para a América Latina, com as experiências de tematização do idioma aqui debatidas, mas também com a homenagem à artistas e $\operatorname{amigos}^{64}$, se não lograram seu objetivo maior, que era o de inserir o público leitor numa rede de referências latino-americanas, divulgando autores vizinhos, acabaram tendo como resultado indireto sua boa aceitação em países da América Latina, às vezes tornando-a mais familiar ao público e mais aceitável aos críticos hispânicos do que aos leitores especializados e críticos brasileiros.

Em outras palavras, a poesia de Thiago de Mello é, nos dias de hoje, mais conhecida - e o poeta mais admirado - em países como Peru, Bolívia, Cuba, Venezuela, Nicarágua do que entre as instâncias legitimadoras de cultura no Brasil. Nestes países em que a poesia mantém fortes traços retóricos e resquícios românticos e nerudianos, Thiago é respeitado como um genuíno cantor da América Latina, tal como aqueles que ele homenageia sistematicamente em sua poesia.

A título de conclusão: uma das considerações possíveis a respeito da abertura de Thiago para o enlaçamento entre a cultura e línguas portuguesa e espanhola espalhadas por sua obra é a de que, mais do que cumprir sua missão de trazer o diálogo com a América Latina para dentro da literatura brasileira, esta vertente, paradoxalmente, fez com que o poeta se tornasse mais legível e apreciável nos países vizinhos, tematizados e reconhecidos em seus poemas, do que no Brasil.

63 Apesar deste aparente consenso acadêmico em torno do caráter menor da obra de Thiago de Mello, cabe ressaltar que sua produção recente tem alcançado algum êxito, como a conquista do prêmio Jabuti pelo livro De uma vez por todas, além do surgimento de edições comemorativas de seus livros e antologias de poemas organizadas por grandes editoras. Longe de refutar os juízos negativos da crítica especializada, este contexto editorial ajuda a pensar a posição que a poesia de Thiago ocupa no panorama da poesia atual, dando um outro sentido às suas peculiaridades, excessos e limitações.

64 O pintor chileno Nemésio Antunez, o músico, também chileno, Victo Jara, Cristobal Pakarati, são apenas alguns dos amigos a quem o autor dedica longos poemas, trazendo estas figuras, desconhecidas do público brasileiro, para perto de seus leitores, fechando uma rede de amizades e ternuras que sua poesia busca desenhar. 


\section{4- De volta à ilha}

\section{1- Saudades da utopia ou vergonha de um dia ter sonhado?}

Após o longo período de exílio forçado, os dois autores conquistam o direito de retornar ao Brasil e dar prosseguimento a uma nova etapa de suas produções literárias. O primeiro a voltar ao país é Ferreira Gullar, em 10 de março de 1977. Impulsionado pelo sucesso do Poema Sujo, o poeta decide desafiar o regime militar, ainda resoluto no uso da truculência, e numa atitude provocativa retorna ao país com a ajuda de amigos. Sua chegada é conturbada e mesmo com a presença de diversos companheiros e intelectuais no aeroporto, pressionando pela segurança de Gullar, ele é preso no dia seguinte, sendo interrogado por 72 horas, recebendo ameaças, até ser definitivamente libertado, novamente graças a atuação pública de personagens ilustres da inteligência brasileira.

A volta de Thiago de Mello é posterior e, por isso, menos problemática; já coincide com a anistia e com o processo de redemocratização. O que é comum aos dois, e a todos que foram obrigados a saírem do país, é a chegada a um Brasil bastante diferente do que deixaram em meio a agitação política característica do final dos anos 60 e início dos 70. Diferentemente do ímpeto coletivo que guiou a atuação de Gullar no CPC eno grupo Opinião, especialmente nas peças de teatro que escreveu, ou na vivência de Thiago de Mello com o grupo ligado à editora Civilização Brasileira, a sensação era que os planos de um outro Brasil, tão sonhado e cintilante nos anos de exílio, pareciam ter sido sufocados de vez junto ao clima efusivo de outrora. Sem nenhum cenário de triunfo glorioso das forças políticas opostas ao regime militar, a sensação era de que o governo ruía dentro de seu próprio cansaço, concluindo sua prometida transição lenta, segura e gradual.

O clima cultural parecia não oferecer mais espaço para proposições conjuntas, transgressoras, ousadas. A literatura mostrava-se engessada, oscilando entre uma rebeldia ainda confusa pelas transformações em marcha e a morna elaboração para atender ao emergente mercado de massas. Os projetos de luta armada estavam definitivamente enterrados; Lamarca e Marighella estavam mortos e sem qualquer indício de se converterem em símbolos de resistência ou combustível humanos para novas revoltas.

É bem verdade, porém, que graças a atuação de artistas, intelectuais e novas lideranças 
políticas, o período da ditadura seria recontado na historiografia brasileira sob a ótica das vítimas do regime, ponto de vista que permanece praticamente consensual, malgrado algumas recentes tentativas de revisionismo histórico de fundo conservador ${ }^{65}$. Apesar disso, a vitória das forças progressistas no plano simbólico e seu aparente triunfo na "batalha pela memória" em relação aos anos de chumbo (NAPOLITANO, 2010) não se refletiam efetivamente no jogo de forças pelo poder político ou numa inserção promissora destas forças no reticente jogo democrático. Em outras palavras, a ditadura parecia ter cumprido mais uma etapa da modernização conservadora brasileira e há tempos preparava uma serena transição para deixar a cena, mediada por uma elite econômica consciente de que as coisas precisavam mudar para continuarem iguais.

O resultado destas modificações político-sociais são sentidos nos livros que os autores publicam na década de 80. Na vertigem do dia (1980) e Barulhos (1987) de Ferreira Gullar, e Mormaço na Floresta (1984) e Num campos de margaridas (1986), de Thiago de Mello. Sobretudo as obras de Gullar correspondem a um movimento de transição de uma etapa altamente politizada, que começara com os versos de cordel e encontrara o momento de maior condensação emotiva e crítica no Poema Sujo, para uma poesia mais voltada para os dramas pessoais do sujeito, acentuando uma aguda reflexão metafísica, presente desde a gênese de sua trajetória poética, mas nos últimos livro ganhando certa autonomia em relação ao mundo social. A morte - tema sempre presente em sua poética, mas muitas vezes subordinada ora ao impasses da linguagem, em a A Luta Corporal, ora ao desejo socialmente participante, como num poema da força de "Notícia da morte de Alberto Silva" - passa então a ocupar o centro de suas reflexões, vista ainda de maneira crua, materialista, reforçada pelo estilo coloquial testado continuamente pelo autor, mas sem a pressão da denúncia.

Com Thiago de Mello esta transição é menos evidente. A persistência de uma aspiração utópica, mesmo em seus livro mais recentes, poderia ser facilmente lida como a perpetuação de um compromisso inabalável do autor com a esperança e as mudanças sociais. No entanto, numa leitura mais cuidadosa, é lícito afirmar que há ali uma espécie de deformação plangente deste desejo renovador. O locus da mudança - a alvorada que irrompe após as trevas da desigualdade - é seu assunto central desde Faz escuro mas eu canto, livro em que o sujeito assume, de fato, um viés

65 Vide, por exemplo, o polêmico caso em que o editorial de um grande jornal de São Paulo se referiu à ditadura brasileira como "ditabranda", defendendo, com o infeliz trocadilho, que o governo militar no Brasil teria sido razoavelmente pacato se comparado aos dos vizinhos latino-americanos, sobretudo Chile e Argentina. 
comprometido com a superação da pobreza e um ethos, por assim dizer, revolucionário. Não obstante, a revolução timidamente exaltada pelo poeta é ambígua, abstrata: deseja desde seus primórdios relacionar-se ao imaginário político de esquerda, pregar a necessária mudança social, às vezes aceitando até a violência como modo justo de superação da desigualdade ${ }^{66}$, mas quase sempre volta-se, no auge de sua exaltação libertária, para uma fraternidade cristã, pregando o amor como unidade de atuação, tematizando os inimigos mordazes anteriormente mencionados para perdoá-los em seguida ${ }^{67}$.

Tal ambiguidade, apenas numa leitura amigável e complacente poderia ser entendida como saída original, capaz de indicar um complexidade expressiva digna de elogios pelo avaliador. A fusão criativa dos ideias marxistas com os valores básicos de um "cristianismo laico" marcam uma afinidade (mais política e filosófica do que propriamente religiosa) com as alas progressistas do clero brasileiro, com o seu amigo Paulo Freire e a chamada Teologia da Libertação. No decorrer da obra poética de Thiago de Mello, tal aproximação se mostrará, de fato, controversa, confusa, desmedida e muitas vezes resolvida com jargões e saídas fáceis. Assim, observamos uma oscilação entre uma proposição ancorada - ainda que sem nunca se decidir pelo rigor materialista visível na obra de Gullar - numa proposição histórica, de fundo revolucionário:

\footnotetext{
O tempo do inimigo se acrescenta de tão turvo poder, que está marcando - o tempo do inimigo está marcando a hora da rebeldia em nosso amor.
}

(MELLO, 1984, p. 269)

Os índices de uma luta transformadora, marcada no poema pela rebeldia, pela descrição algo maniqueista de um inimigo a ser vencido e que representa todas as mazelas da injustiça social, são anulados por uma vertente mais piedosa do autor. São versos que apelam quase sempre para o amor, para as metáforas voltadas para o jogo claro/escuro, que prometem um mundo mais digno de se viver, descuidando do movimento social, político e histórico que nos levaria até ele: é como se o canto, feito com todo o amor colhido pela convivência do eu-lírico, fosse a prova inequívoca da

66 A legitimação da violência popular ganha forma em passagens altamente metafóricas: “[o povo] no seu destino imenso de ser livre,/ que se expande em fragor de tempestades/ e gera brados balizando o rumo/ por onde avança o povo rebelado" (MELLO, 1984, p. 270).

67 Miguel Sanches Neto (1998) comenta longamente as peculiaridades deste locus enunciativo da poesia de Thiago de Mello, definindo-a como uma "poética da camaradagem"; indicação que nos parece interessante para iluminar a produção poética do autor. 
beleza que, utopicamente, chegará:

Só viverá o homem novo, não importa quando, um dia, se os que por ele sofremos formos capazes de ser semente e flor desse homem.

(MELLO, 1984, p. 352)

Portanto, enquanto identificamos na poesia de Gullar um gradativo distanciamento dos temas mais diretamente ligados a uma crítica política no sentido convencional da literatura participante, em Thiago de Mello a transição da euforia transformadora para um momento de refluxo das esperanças coletivas é mais difícil de detectar. Ela se mostrará não no abandono da utopia, mas na sua definitiva autonomização da realidade histórica. O poeta amazonense mantém poeticamente intactas as convicções dos anos de maior entusiasmo militante, a diferença é que de um canto urgente, pregando que a "manhã já vai chegar" ou a sensação moral de que "é preciso fazer alguma coisa", a matéria social, nestes livros mais recentes, aponta para um futuro indefinido, às vezes sabidamente inalcançável, conforme veremos em detalhes um pouco mais a frente.

A urgência do canto, como símbolo ritual da renovação humanizadora, deixa de ser arma de luta e passa a ser consolo. A fusão canto-amor-luta perde sua força e em alguns momentos a voz poética se permite até mesmo questionar-se sobre a possibilidade de se alcançar o mundo almejado, mesmo que a resposta venha em seguida, reafirmando o compromisso inicial.

Na Vertigem do Dia e Barulhos, de Ferreira Gullar, e Mormaço na Floresta e Num campo de margaridas, de Thiago de Mello, estão inseridos num período confuso da história recente, cercado de expectativas e reviravoltas no plano biográfico dos autores e do contexto com o qual dialogam. São poemas que exploram o reencontro com o lugar natal - daí a força com que a memória e a cidade da infância são tematizados nesta obras - e inauguram a entrada dos autores no outono da velhice. São poemas que testemunharam a anistia e a abertura política, mas sequer intuem a derrocada da União Soviética e o esvaziamento da dualidade ideológica que marcara a Guerra Fria. Enfim, podemos notar neste livros que publicam na década de 1980 uma persistência do sentido de combate e denúncia - que será negado nas obras seguintes de Gullar, e atenuado na poesia de Thiago de Mello - ao mesmo que tempo que já anunciam o interesse por motivos poéticos que, se não são totalmente estranhos a sua poesia, serão abundantemente explorados nos livros publicados no anos 1990, como a velhice e a intuição da morte, a memória e a cidade natal. 
Se acompanharmos as respostas que Ferreira Gullar e Thiago de Mello elaboram diante da prefiguração de um um mundo desencantado, de um período de refluxo ideológico e crise da utopia revolucionária, veremos que elas não são de todo pessoais e isoladas. Em livro extremamente provocador, carregado de ironias, Terry Eagleton (1998) remonta os pressupostos históricos da chamada pós-modernidade para questionar a natureza, a seu ver, conformista de suas conclusões. Para um mundo órfão dos ideais revolucionários, no qual a consolidação ideológica do capital, via indústria da informação, adquire eficiência nunca antes vista, Eagleton observa, acidamente, que para as antigas vozes de contestação, agora isoladas em um casulo de anacronismo, cabem algumas saídas possíveis, que ele enumera e descreve impiedosamente:

Como se espera que a esquerda política reagisse a uma derrota desse tipo? Muitos, sem dúvida, por ceticismo ou boa fé, descambariam para a direita, arrependendo-se de suas ideias passadas e reputando-as idealismo infantil. Outros manteriam a fé por hábito ou nostalgia, aferrando-se a uma identidade ilusória e correndo o risco de neurose que dela pode advir. Existem, afinal, aqueles devotos para quem nada neste mundo serve para desvirtuar suas crenças - aqueles cristãos, por exemplo, que, fiéis ao que os doutores da ciência chamam de "subdeterminação de dados pela teoria", continuariam a reunir-se sorridentes em torno da mesa eucarística, mesmo depois de todo mundo já ter se dado conta de que os evangelhos são fraudulentos do início ao fim. (EAGLETON, 1998, p. 10)

A espantosa clarividência do diagnóstico de Eagleton nos instiga a enfrentar, nos próximos passos da pesquisa, os livros que Ferreira Gullar e Thiago de Mello publicaram nos anos 90 como respostas díspares a uma mesma situação histórica: o declínio das esquerdas após o esfacelamento do bloco comunista, bem como as consequências decorrentes daí, a saber, a expansão do neoliberalismo e o processo de legitimação em nível global da ideologia de mercado, coroada pelo processo denominado por muitos como globalização. As diversas mudanças que Terry Eagleton acompanha são examinadas de acordo com a ótica perplexa de quem vivenciou as derrotas políticas do marxismo e lança um olhar severamente crítico ao que, para ele, seria uma tentativa de transpor essa derrota política para o plano da teoria, a qual se congregaria em torno dos estudos pósmodernos.

Interessa recompor este cenário para investigarmos os fundamentos das viradas que ocorrem nas poéticas dos autores estudados desde o momento de retorno ao Brasil, com uma transição dos temas e formas já em andamento nos anos 80, passando para um significativo período de silêncio, até o lançamento dos seus últimos livros, já para fins dos anos 90, com De uma vez por todas e 
Campo de Milagres de Thiago de Mello, e Muitas Vozes, de Ferreira Gullar ${ }^{68}$.

Os efeitos destas mudanças são duramente sentidos pela poesia contemporânea. Entramos, pois, numa época em que a poesia aprofunda a perda de público leitor e sua importância no conjunto da literatura e da própria engrenagem social, de tal maneira que nunca se discutiu com tanta plausibilidade o tópico da morte da poesia. Para obras em que o ato criador fundamentava-se numa visão estético-política na qual a obra de arte almejava ser parte material da própria vida, as duras mudanças conjunturais certamente levariam os dois poetas que acompanhamos até aqui ou ao silêncio absoluto, ensaiado por Gullar nos longos períodos em que ficou sem lançar livros inéditos de poesia, ou na pretensa despedida que Thiago de Mello anunciava, desde o título, em De uma vez por todas, ou ainda à mudanças profundas de estilo e orientação poética.

As transformações acabam inevitavelmente se impondo e os rumos são semelhantes àqueles profetizados pelo texto de Eagleton. Gullar adota publicamente um discurso que tangencia o derrotismo: suas posições políticas são revistas, passagens de sua poesia mais ligada a um ideal socialista são duramente renegadas, tolhidas e taxadas de ingênuas; as aspirações revolucionárias outrora celebradas passam a ocupar o vão das ilusões juvenis. O discurso de abandono da militância e da auto-crítica é repisado em algumas entrevistas do autor. Numa delas, para a revista Bravo, em março de 2009, ele é indagado se continua acreditando na validade do engajamento poético. Sua resposta é contundente e enfática:

Não, de jeito nenhum. Os poetas, agora, irão se engajar em quê? No socialismo ridículo do Hugo Chávez? Foi um engano imaginar que versos contribuiriam para a revolução social. Admito que um poema consiga iluminar o leitor, consiga lhe abrir a cabeça. Mas daí a mudar a sociedade... Muito complicado! Abandonei todos os mitos daquela época. Não creio mais em luta de classes. Já aprendi que o capitalismo é como a natureza: invencível. (GULLAR, 2009)

Em seguida, na mesma entrevista, reforça enfaticamente sua desilusão com o projeto socialista e um decidido conformismo diante da "indestrutibilidade" do sistema capitalista:

Repito: o capitalismo vai imperar porque segue a lógica da natureza. É brutal, é feroz, é amoral. Não demonstra piedade por nada nem por ninguém. Em

68 Para esta reflexão deixaremos parcialmente de fora o livro Em Alguma Parte Alguma (2010), recém lançado por Ferreira Gullar. Por ter sido publicado no decorrer da elaboração deste trabalho, seria temerário realizarmos um mergulho mais profundo nas questões que o livro suscita. De todo modo, cumpre assinalar que com base numa leitura inicial do livro e na sua recepção crítica mais imediata, podemos afirmar que ele surge muito mais como extensão do movimento aqui estudado do que como nova ruptura ou refutação das hipóteses aqui debatidas. 
compensação, nos oferece uma série de benefícios. O capitalismo, à semelhança da natureza, se desenvolve espontaneamente. Não precisa que meia dúzia de burocratas dite o rumo das coisas, como acontecia nos regimes socialistas. (GULLAR, 2009)

O impacto desta mudança simultânea, do autor Ferreira Gullar, e do contexto político mundial, certamente não tendem, por si só, a gerar mudanças qualitativas, para pior ou melhor, em seus poemas. No entanto, ele demanda alterações formais marcantes: 1) a preferência por temas como a morte, a memória, carregados de metafísica, em detrimento à denúncia social, à representação poética dos humildes e explorados; 2) a apuração da linguagem poética; mesmo mantendo a base coloquial que caracteriza seus melhores versos, o estilo é condensado ao extremo por um autor mais rigoroso, talvez mais maduro no manejo da linguagem crua e expressiva que sempre buscara. Na fortuna crítica centrada neste último livro de Gullar, nota-se uma recepção bastante favorável às investidas do autor em direção ao drama existencial. Suas abordagens sobre a morte, o tempo, o espaço cósmico enquanto símbolo do desamparo humano e da fugacidade cintilante da vida, são recebidos com entusiasmo pelos seus críticos mais importantes.

A base poética que as engloba também é descrita com termos elogiosos, nos quais frequentemente encontramos termos positivos da crítica literária, como "maturidade expressiva", "condensação lírica”, "domínio da forma”, para ficarmos somente em alguns dos mais recorrentes. Se há um grande mérito nesta nova etapa, observado, por exemplo, por Davi Arrigucci Jr. (1999), é o de o poeta conseguir alcançar maior autonomia em relação às sempre polêmicas opiniões políticas e estéticas ${ }^{69}$, em oposição a conversão algo simplista de sua poesia a objeto de afirmação de uma causa qualquer, seja a do concretismo, do neoconcretismo ou a do popular-nacionalismo.

Neste sentido, repetimos, as mudanças da obra de Thiago de Mello nesta virada dos anos 90 são menos nítidas. A persistência de um otimismo congratulante, que segue anunciando auroras, cada vez mais rarefeitas e distantes, é uma marca que dá a sua obra uma posição ímpar no cenário da poesia brasileira atual. Num ambiente em que o pessimismo é elevado à categoria de regra de composição, corroborado por um formalismo academicista altamente evanescente, já alertado por Iumna Simon (1993) em importante ensaio já citado, a voz de Thiago de Mello destoa radicalmente

69 Ao mesmo tempo em que profere a impossibilidade do socialismo, despertando a ira de antigos companheiros e leitores, Gullar acumulou também oponentes atrozes por conta de outras polêmicas, sobretudo por conta de seus artigos sobre artes plásticas, nos quais defende o esgotamento das vanguardas artísticas e ataca duramente vários segmentos da arte contemporânea. 
do individualismo vigente na poesia brasileira (e por que não mundial) em fins do século XX.

O risco assumido por tal abordagem é imenso: pode desembocar em anúncios vazios de mudanças improváveis, pode ofuscar a inquietação do indivíduo, cuja complexidade latente é o centro irradiador de sentidos da lírica, além de resultar em logro político, repetição, mais por hábito do que por convicção, de um discurso potencialmente demagógico que pode acabar se cristalizando em dogma.

De fato, a obra do poeta amazonense chega a escorregar por cada uma destas armadilhas e resulta, em seu conjunto, num retrato pouco convincente da persistência da dimensão utópica em nosso tempo. Diferentemente da eficácia simbólica dos "sonhos diurnos" defendidos por Ernst Bloch (2005), as auroras da poesia de Thiago, imersas num mundo hostil à esperança de renovação e justiça, são quase sempre sonhos evanescentes que se repetem monotonamente no interior de sua obra. Lembrando novamente das palavras de Eagleton, eles representam, talvez, a nostalgia de um tempo de maior vitalidade política que, por princípio ou segurança, o autor não aceita abrir mão. Essa dificuldade em problematizar o contexto atual e lançar sobre ele uma perspectiva realmente convincente no plano crítico é, mais do que as virtudes do autor, que exploramos em outras partes do trabalho, a tônica do olhar que a crítica literária vem lançando sobre a poesia de Thiago:

Como quem não domina seus recursos formais, Thiago de Mello se deixa embalar por composições que são, a um só tempo, cantigas melodiosas e anotações pessoais - mas, em nenhum dos dois casos, se trata de grande poesia. (...)No Brasil, a sua poesia é uma das que mais se aproximou do texto discursivo, e é lícito afirmar que, desejando ser poeta, ele é quase sempre um prosador. A distinção é necessária por vários motivos. Inicialmente, porque retrata a mania quase obrigatória dos poemas políticos, que é a grande extensão da obra. A musicalidade também se compromete, e por fim a expressão poética se reduz ao quase nada. (FORTUNA, 1986)

A peculiaridade da poesia de Thiago de Mello, apartada das principais linhas verificadas pela crítica na poesia contemporânea, é tão inusitada como a escolha do autor em, ao retornar do exílio, viver na pequena cidade de Barreirinha, no interior do Amazonas. O caminho solitário de sua poesia é coroada pelo seu distanciamento opcional dos grandes centros brasileiros e o encontro com sua cidade natal. Poderíamos pensar até num exílio depois do exílio, este último opcional, desejado, mas nem por isso imune aos efeitos de deslocamento e estranhamento, da incompreensão e do distanciamento de sua poesia em relação à crítica e ao público leitor especializado. Longe dos centros legitimadores de cultura, a poesia de Thiago de Mello será muitas vezes recebida sob o 
duvidoso rótulo do regionalismo. Atuando de longe nos debates literários, com os quais se envolve cada vez menos, e decidido a gastar seus dias entre a calma da floresta e a amizade dos povos ribeirinhos, o autor segue distante dos debates mais solenes da crítica, observando de longe se sem interesse as novas tendencias poéticas, redimindo-se do refinado discurso da arte atual. É impossível analisar a obra do poeta sem relacionar em termos largos e flexíveis esta sua peculiaridade quase exótica dentro da lírica contemporânea e este exílio opcional do escritor em sua afastada terra natal.

\section{2- Globalização e América Latina, memória e resistência}

A derrocada do bloco socialista e seu impacto traumático nos poetas que viveram a euforia popular-revolucionária dos anos 60-70 explica apenas parte da guinada das suas obras neste período pós-Guerra Fria. Para compreendermos a nova dimensão alcançada pelo tópico da latinidade (ou, de alguma maneira, a supressão desse tópico) nos livros que Ferreira Gullar e Thiago de Mello publicam nos anos 90, é necessário passarmos pelo problemático conceito de "globalização". Nas palavras do teórico Zigmunt Bauman (1999), a repetição pouco criteriosa elevou o termo à condição de palavra da moda, um desses tantos "conceitos fetiches" aplicados para explicar os mais diferentes dilemas de determinado tempo.

Ao discorrer sobre o tema, Bauman logo trata de separar o conceito de globalização de uma visão mais universalista, em marcha até mesmo antes do ciclo das grandes navegações. Segundo ele:

A ideia de "universalização" foi cunhada com a maré montante dos recursos das
potências modernas e das ambições intelectuais modernas. Toda a família de
conceitos anunciava em uníssono a vontade de tornar o mundo diferente e melhor
do que fora e de expandir a mudança e a melhoria em escala global, à dimensão da
espécie. Além disso, declarava a intenção de tornar semelhantes as condições de
vida de todos, em toda parte, e, portanto, as oportunidades de vida para todo
mundo; talvez mesmo torná-las iguais. Nada disso restou no significado de
globalização, tal como formulado no discurso atual. O novo termo refere-se
primordialmente aos efeitos globais, notoriamente não pretendidos e imprevistos, e
não às iniciativas e empreendimentos globais. (BAUMAN, 1999, p. 66) 
Em termos sintéticos, podemos definir a "globalização" - este termo tão examinado em todas as áreas do conhecimento, mas mesmo assim ainda deixado em suspenso, entre aspas, dada a abundância e controvérsia das análises - como o impacto sentido de maneira particularmente tensa em nosso tempo e resultante, de alguma maneira, do enfraquecimento dos estados nacionais, tal como fundamentado na ascensão da era moderna. Isso se reflete na economia, com a organização em blocos de países e na circulação volúvel do capital financeiro-especulativo pelo globo terrestre, sob a liderança de investidores e empresas transnacionais; se reflete na cultura, com a intensificação e expansão estandardizada da indústria cultural, com seus modelos de entretenimento e espetáculo, intensificados com os avanços da tecnologia da informação; se reflete na organização social dos países, aumentando as desigualdades regionais e criando fenômenos como a emigração em massa nos países mais pobres, marcada pela busca de melhores opções nas grandes potências; se reflete, enfim, em todas a áreas do conhecimento, do consumo e do modo de estar e sentir o mundo em nosso tempo.

O certo é que a circulação em nível global de determinados repertórios ideológicos, artísticos, humanos, tem convergido para a construção de fronteiras cada vez mais diluídas entre as antigas nações. Retomando o trecho citado de Bauman, a globalização é muito mais uma consequência, um efeito mais ou menos imprevisto e incontrolável das novas estratégias de expansão do capitalismo tardio, cada vez mais flutuante e agressivo, do que um projeto em construção ou uma proposta; é mais um turbilhão que a tudo arrasta, do que um convite.

As críticas mais comuns à ideia de globalização acusam seus teóricos e defensores mais ilustres de serem coniventes com a crescente autonomia da economia (de mercado) em relação aos campos políticos, ainda fundamentalmente nacionais e territorializados, bem como de camuflar a impregnação passiva da ideologia de mercado em todos os aspectos da vida, fantasiada com a máscara ilusória de um "mundo sem fronteiras”, sem utopias e, se o fosse possível, sem história.

Nas duas poéticas examinadas no decorrer deste trabalho, podemos observar que a questão do diálogo latino-americano, objeto central de nosso estudo, sofre modificações profundas na passagem deste período-chave de nosso tempo. Poderíamos inicialmente questionar se a formulação de laços comunitários, difundidos pela voz poética participante, perderia seu ímpeto conforme a consolidação do processo globalizador confundisse diferenças e afinidades entre os países, cada vez mais próximos na cartilha política que têm a cumprir para garantir investimentos estrangeiros e nos 
padrões de consumo - inclusive cultural - verificados na disseminação de um modelo, basicamente norte-americano. Ao desejo de aproximação e cooperação solidária engendrados em boa parte dos poetas brasileiros, em meados do século $\mathrm{XX}$, se prosseguiria a conformação frente aos blocos, tal como o Mercosul, de caráter primordialmente comercial, deixando de fazer sentido, ao menos para a literatura, cumprir um papel de mediação e conhecimento mútuo entre as diferentes culturas da América Latina?

Para refletirmos sobre esta mudanças partiremos de uma ótica em que o comunitarismo atua como categoria ainda válida para se pensar a matéria literária e social. Para isto, recorremos novamente às ideias de Benjamin Abdala Jr. (2003) para quem os trânsitos entre a literatura brasileira e as culturas afins, ou seja, aquelas com as quais o país compartilha paralelismos sóciohistóricos mais evidente, são extremamente produtivos para uma aproximação soberana e podem ser ativados como estratégia de resistência, desde que efetuado às margens da especulação interesseira e mercantilizada das imposições globalizantes. O crítico orienta seu pensamento tendo como norte os países de língua portuguesa, em cima dos quais desenvolve um modelo de comparatismo literário descolonizado, mas deixa em perspectiva também a América Latina:

Em lugar de um comparatismo da necessidade que vem da circulação norte/sul, vamos promover, pois, o comparatismo da solidariedade, buscando o que existe de próprio e de comum em nossas culturas. Vemos sobretudo duas laçadas, duas perspectivas simultâneas de aproximação: entre os países hispano-americanos e entre os países de língua (oficial) portuguesa (ABDALA Jr., 2003, p. 67)

Novas formas de aproximação comunitária entre os países seriam, então, desejáveis e cada vez mais possíveis, segundo o autor, tendo em vista os avanços no âmbito da comunicação e da circulação promovidas pelo avanço da mundialização da economia capitalista bem como pela posição política e econômica mais ou menos similar que o consenso neoliberal imprimiu nos países latino-americanos ${ }^{70}$. O resgate crítico de laços e diálogos entre as culturas abriria espaço para novas estratégias de ação conjunta, atuando como contraponto dialético à tendência globalizadora, revertendo (e invertendo) a disseminação de padrões uniformizados, devidamente aprovados pelas forças hegemônicas, em prol de uma circulação que respeite as diferenças culturais e busque forças

70 Segundo Néstor García Canclini, "nunca uma política de reestruturação [a neoliberal], nem a populista, nem a desenvolvimentista, havia conseguido se impor de forma simultânea e com tanta homogeneidade no conjunto dos países latino-americanos. (...) Nunca antes tivemos a oportunidade de sintonizar as experiências latino-americanas numa única frequência" (CANCLINI, 2008, p. 50). Desse modo, a dispendiosa aventura da globalização neoliberal poderia deixar ferramentas e instrumentos para uma superação conjunta por parte dos países do continente. 
na diversidade, consolidando vínculos a partir de trânsitos horizontais, críticos e solidários.

Portanto, talvez mais até do que no contexto de polaridade ideológica dos anos 60, o diálogo supranacional teria atualmente um importante papel de resistência e questionamento a cumprir no cerne da literatura contemporânea. Problematizar alternativas às mazelas sociais advindas das novas práticas econômicas e lançar mão de estratégias críticas ao cenário de "desordem global" (BAUMAN, 1999, p. 44), decorrente da descentralização do capital e de sua reprodução socialmente insensível, permanece sendo uma contribuição valiosa que a literatura (e também a crítica literária e social) tem a oferecer nestes tempos de crise.

No caso dos poetas estudados, a aspiração latino-americana que acompanhamos em suas obras desde a década de 60, passaria por duras provações, e necessárias transformações, após o retorno ao Brasil e ao novo contexto encontrado neste regresso. $\mathrm{O}$ baque é ainda mais intenso se o tomarmos, como temos sugerido no decorrer do trabalho, a vertente americanista da poesia de Thiago de Mello e Ferreira Gullar como parte integrante de um projeto mais amplo, de ordem política e social, que visava, em última instância, a própria tomada do poder, sendo a poesia parte indispensável de um longo projeto de conscientização popular, tomada de atitude e mudança social. Ora, ao chegarem novamente no Brasil, após os anos de exílio, os autores encontram um ambiente renovado: o papel pedagógico do intelectual e sua alardeada missão enquanto catalisador de revoltas estava numa crise aparentemente terminal; a confiança no poder mobilizador da arte também não encontrava defensores como nos duros debates sobre o papel social da arte nos anos 60; a familiaridade dos grandes centros urbanos com os produtos da moderna indústria cultural norte-americana e com os objetos de consumo das empresas transnacionais era tão salutar ${ }^{71}$ que as obras latino-americanas que reivindicavam para si qualquer grau de "autenticidade" cultural, só poderiam ser consideradas sob o rótulo de ultrapassado exotismo. Soma-se a isso os traumas e decepções que a experiência do golpe militar chileno gerou nos dois autores e temos uma ideia dos impasses que se seguiriam na forma (mesmo na necessidade e interesse) de seguir cantando a América Latina nos tempos pouco acolhedores ao canto solidário. Derrotado o projeto político que trouxera a América Latina para o centro da cultura brasileira, que espaço ela poderia ocupar (se é que poderia ocupar algum) nas obras de Ferreira Gullar e Thiago de Mello nestes anos de inflexão

71 A respeito da relação tensa entre a indústria cultural e a "alta literatura" no contexto brasileiro, indica-se a leitura do artigo "Literatura e Cultura de Massa", de Silviano Santiago (2004), e o texto "Ainda a censura", de Tânia Pellegrini (2001). 
política?

Algumas hipóteses para esta questão serão desenvolvidas nos próximos capítulos, dedicados a examinar os resquícios, os ecos e resíduos daqueles momentos de euforia em torno da identidade latino-americana nos últimos livros que os autores lançaram até aqui. Adiantamos, porém, que seus poemas não mais poderiam ser concebidos sob o véu do entusiasmo e da celebração identitária. Sem espaço para um certo heró́smo voluntarioso que emana em vários momentos da poesia dos autores durante a década de 60 e 70, a América Latina migrará para o espaço da memória, das lembranças que buscam ser organizadas e esperam revelar no passado erros e acertos que preservem a integridade destes sujeitos e ofereçam novos olhares sobre o outro como forma de entendermos, quem sabe, a nós mesmo.

\section{3- De uma vez por todas, América}

São dois os livros de poesia publicados por Thiago de Mello nos anos 90, De uma vez por todas, lançado em 1996, e Campo de Milagres, de 1998. O primeiro anuncia já no título uma despedida; o poeta, cansado pela longa marcha da vida, reivindica um merecido descanso do ofício que fora, em sua obra, sinônimo do próprio existir:

\section{Este livro, de um homem e sua vida, que nada traz de novo além do amor, me despede da mágica aventura de dar sonho sonoro à humana argila e transformar estrelas em palavras: mistura de alegria e agonia.}

(MELLO, 1996, p. 31)

Nos primeiros poemas do livro a despedida presta contas principalmente aos leitores e aos críticos, sempre severos em relação a sua obra. No poema "Palavras perto do peito", por exemplo, a defesa de sua poética parte da afirmação de antigos propósitos inconfundíveis de sua obra, como o compromisso com a liberdade e o desacordo com o formalismo academicista:

$$
\text { (...) }
$$

(Alguns, da arte só pela arte, me torcem a cara quando canto em nome do meu povo 


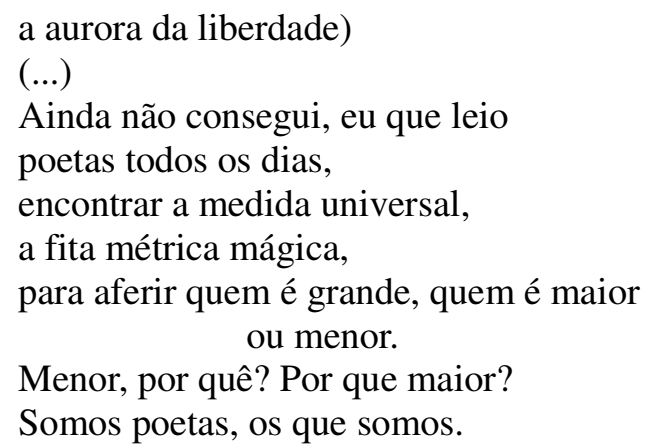

(MELLO, 1996, p. 35-37)

Não obstante, nestes mesmos poemas, o autor, como parte inequívoca de uma explicação/justificação de sua poesia, desfila autorreferências, a seus versos mais conhecidos e a passagens de sua biografia. Também são abundantes as citações de autores consagrados, eruditos, vários deles símbolos de uma poesia estetizante e de extremo apuro formal, como é o caso de Paul Valéry e T. S. Eliot, citado em mais de um poema do livro, e de João Cabral de Mello Neto. Exibindo um conhecimento vasto do cânone poético, o sujeito dos poemas de Thiago de Mello se insere numa tradição literária das mais altas linhagens, sobretudo ao relatar a convivência e o sentimento de amizade que nutria com vários autores brasileiros e latino-americanos.

Como já foi analisado, o tom das citações é de humildade por parte da voz poética, mas ressalta numa rede fraternal de vozes e intertextos que transitam na tessitura do livro de Thiago de Mello, marcando a construção de um ethos cosmopolita e erudito. Apresentemos, pois, alguns exemplos:

É a escolha

sobre a qual pedi grave a Albert Camus, em um bar da França, que me desse mais luz ao meu opaco entendimento.

(MELLO, 1996, p. 32)

Mas gosto tanto de Heidegger quando ele diz que poesia é a fundação do ser pela palavra da boca.

(MELLO, 1996, p. 50)

Noite já tarde, o Rosa me esperando, aflito me pedia, era uma consoante de vida ou morte, era uma angústia que me assustava, ainda me assusta agora, 
"errei num verbo, o do pêlo, aquela vaca, na luz noturna, não reluz, obluz".

(MELLO, 1996, p.77)

A mão de José Lins do Rego escrevendo

Fogo Morto,

a mesma mão que apertava a minha

no seu derradeiro dia.

(MELLO, 1996, p. 81)

[Manuel Bandeira] me dá, do João, o "Cão Sem Plumas":

"É seco, mas dá sumo, não esprema".

No mesmo dia li. Ano passado li,

acho que leio todo ano e acabo triste:

"É seco, mas tem sumo, não esprema".

Um fim de tarde ele me chama

ao seu apartamento, riba e mar.

$\mathrm{Na}$ voz do próprio T. S. Eliot,

ouvimos The Hollow Men.

(MELLO, 1996, 74)

Outra marca destas passagens em que o poeta reflete sobre sua trajetória artística e se defende, literariamente, do discurso crítico em torno de sua obra, está presente na enfática afirmação de seu estilo, assumindo um vínculo de continuidade, talvez até de professada repetição, do seus temas e abordagens. A começar pela epígrafe do livro, retirada dos livros de Jorge Luiz Borges: "De un hombre que ha cumplido los setenta años que nos aconseja David, poco podremos esperar, salvo el manejo consabido de unas destrezas, una que outra ligera variación y hartas repeticiones"*- (apud MELLO, 1996, p. 28).

Podemos retirar da epígrafe duas ideias principais - além, e claro, do importante sinal de se tratar de um poeta hispano-americano - que merecem uma consideração mais atenta. Primeiro, a marca de enunciação fixada na velhice, com o poeta já beirando os 70 anos, envolto no cansaço do corpo, na ameaça mais concreta da morte e num desejo de repouso e reclusão usualmente atribuídos aos indícios da velhice. Em segundo lugar, um aviso solene de que o livro não pretende alcançar qualquer novidade em relação ao timbre já consolidado do autor, trata-se, pois, de "hartas repeticiones". Neste sentido, o escritor anuncia desde o início o caráter de continuidade do livro, seu desinteresse em atender a pedidos de inovação, enfim, sua recusa em flertar com qualquer

* De um homem que já chegou aos 70 anos que nos aconselha David, pouco podemos esperar. Salvo o manejo consabido de umas destrezas, uma ou outra ligeira variação e fartas repetições. 
ímpeto neófito.

Estas duas questões aparecem interligadas: a afirmação de um estilo que não se quer "antenado" à novas formas ou modas é, de algum modo, justificada por características da idade, do ponto outonal da vida do qual o sujeito se apresenta. Como afirma em chave literal no poema "Os impenetráveis" $\stackrel{72}{ }$, o autor renega estratégias obscuras e esteticizantes de trabalhar a poesia, malgrado, como já dissemos, teça homenagens a poetas frequentemente taxados de herméticos, como Valery e Eliot. Em outras passagens, o aviso de continuidade formal contido na epígrafe, bem como de uma marca estilística avessa ao experimentalismo e às inovações, é repetido, em tom que oscila entre a auto-explicação e a modéstia, em palavras do poeta:

Mas dito seja, de uma vez por todas,
que nada faço por literatura,
que nada tenho a ver com a história,
mesmo concisa, das letras brasileiras.
Meu compromisso é com a vida do homem
a quem trato de servir com a arte do poema.

(MELLO1996, p. 45)

Sou simplesmente um cantor.

Já disse que nada invento

nem produzo formatos diferentes.

(MELLO, 1996, p. 41)

Nada criei de novo.

Nada acrescentei às formas

tradicionais do verso.

Quem sou eu para criar coisas novas, pôr no verso, Deus me livre, uma invenção?

(MELLO, 1996, p. 46)

No que refere ao cenário formal de De uma vez por todas, os avisos de conservação programática do estilo consolidado pelo autor nas década anteriores são seguidos quase à risca. A estrutura do livro, em capítulos que separam seus grandes eixos temático (a poesia, o erotismo, a amizade e a denúncia social), se mantém, em geral, próxima a dos livros anteriores. A diferença é que as separações são mais rígidas fazendo com que a matéria social não "contamine" mais com

72 O poema diz: "Quero confessar, penalizado/ e com palavras brandas/ que não consigo entender/ por mais que leia e releia/ as palavras impenetráveis/ dispostas em forma de verso/ que deram de aparecer./ Textos que se querem poemas/ construídos com o ostensivo empenho/ de não permitir acesso/ ao leitor comum de poesia" (MELLO, 1996, p. 49) 
tanta força as outras facetas de sua poesia.

A presença constante dos versos decassílabos e da redondilha também é confirmada, uma vez mais, nas opções rítmicas, o mesmo valendo para a pouca frequência das rimas, o tom prosaico, reflexivo e contínuo de seus poemas. Nenhum sinal de extravagância ou ousadia em relação ao que produzira até então. No entanto, é preciso relativizarmos tais depoimentos se quisermos compreender as peculiaridades que, mesmo alheias ao pragmatismo consciente do escritor, deixam transparecer as relações que a obra estabelece com o momento histórico no qual está inserida e que, como vimos, é totalmente hostil às propostas eufóricas reproduzidas nos poemas escritos pelo autor até o final dos anos 70.

Por isso, para além da monotonia formal, podemos mapear na articulação expressiva e na posição do sujeito dos poemas de De uma vez por todas duas mudanças substanciais: primeiro, a preocupação mais alongada com a morte, com o estágio da velhice sendo a base biográfica para ponderações mais íntimas sobre a finitude, e, em segundo lugar, uma visível e profunda rearticulação da matéria utópica em seus poemas. Isto é, embora persista uma crença verbalizada na redenção humana, na liberdade e na justiça (dirá o poeta: "Lúcido escrevo, de uma vez por todas,/ que confio no amor e na utopia./ Os cínicos, os fofos, que prefiram/ enganar a favor do apocalipse" (MELLO, 1996, p. 33), as entrelinhas deixam entrever um cenário desfavorável, em que os planos utópicos, outrora criados sobre o chão concreto da história e da rebeldia (vide a sugestão violenta do título A canção do amor armado), passam a ser adiados para um futuro desforme, quase que desligado da ação humana e sem nenhum apelo revolucionário, nos termos comunistas dos anos 60 . O convite à luta em torno de alvoradas redentoras torna-se, nesta nova fase, promessas vagas de tempos menos sombrios; tempos fincados mais no encanto poético que seus versos tentam criar do que num referencial historicamente compartilhado.

Estas sugestões de leitura podem ser discutidas com maior abundância de exemplos no livro seguinte de Thiago de Mello, Campo de Milagres. Em certa medida, a publicação deste novo conjunto de poemas é a contraprova do livro anterior: um triunfo do esforço criador sobre o cansaço. A promessa de despedia contida em De uma vez por todas não é cumprida e sua explicação reside na vitória da criação (eminentemente coletiva e comunicante, para o caso do poeta) sobre o desejo de repouso (individual) do escritor. Os poemas desta nova publicação afirmam que não há como, para o sujeito desta poética - cuja maior particularidade talvez seja o 
radicalismo com que insiste na fusão entre vida e obra - abdicar da poesia sem lançar mão do viver em si. Neste sentido, reforça-se o elo que segue toda sua produção:

Quem me freqüenta de livro

ou de vida, o que afinal

vem a dar no mesmo, sabe

que não padeço da feia

enfermidade da falsa

modéstia.

(MELLO, 1998, p. 32)

O título de fundo religioso - extraído de um poema de Manuel Bandeira, que serve de epígrafe para o livro $^{73}$ - é a metáfora da própria vida, radiante mas com o escuro da morte à espreita: um campo de milagres, semeado pelo potencial solidário do homem e fecundado pelas dádivas da amizade. No decorrer do livro, os pequenos milagres do cotidiano dividem espaço com o ainda presente milagre da utopia, como dissemos anteriormente, cada vez mais apartada de um chão social e histórico. O poeta agora fala também da morte, que na sintomática velhice o encara, mas sempre para refutá-la, para ir além dela e com uma dose comedida de melancolia celebrar a vida. Em De uma vez por todas ela já estava lá, ameaçadora e terna:

Não viverei para ver o homem que eu quero ser.

$(\ldots)$

Posso dizer: preparado para atravessar o rio. Lá do outro lado não sei, nem saber é o meu ofício, o que de mim será feito pois lá sei que não serei dono de meu escolher.

(MELLO, 1996, p. 56)

Como nunca morri, não sei da morte.

Da vida sei, e tanto sei, que faço com este verso uma declaração de amor, talvez de queixa: ela é que vem de mim se despedindo devagar, fatigada de mim, enquanto agarro, com as garras de todos os sentidos, o que ela ainda me dá, sempre encantada.

73 Diz o belo poema de Bandeira: “A vida é um milagre./ O tempo é um milagre./ A memória é um milagre./ Tudo é um milagre./ Tudo, menos a morte,/ que é o fim de todos os milagres” (apud MELLO, 1998, p.16) 
(MELLO, 1996, p 32).

Em Campo de Milagres, novamente a morte é revisitada com dolorosa resignação:

\begin{abstract}
A morte me pertence. Digo a minha. A que nasceu comigo. Vive em mim, de mim vive. Depende do que sou e do que faço. Do que faz comigo, não faz por mal e tem todo o direito de repartir comigo a vida dela.

Não me quer mal, a morte. Se dá bem com as leis do meu ser e seus segredos que talvez os conheça mais do que eu.
\end{abstract}

(MELLO, 1998, p. 67)

Se seguirmos tomando como contraponto a poesia de Ferreira Gullar, veremos que na obra do autor maranhense as imagens da morte também ganham importância em seus livros mais recentes, sobretudo a partir de Barulhos - no qual vários poemas exploram o luto e a melancolia diante da morte de amigos - e em Muitas Vozes - quando a persistência crua da morte de antigos companheiros soma-se às perdas familiares e ao enfrentamento do sujeito com a sua própria morte atinge a consciência inquebrantável que ronda todos os poemas do livro: "a morte é uma certeza invencível" (GULLAR, 2009, p.472).

O que não temos nunca em Gullar é a tentativa de demonstrar calma diante do fim iminente; a poesia de Thiago de Mello indica um aspecto de conformismo do sujeito em relação à morte. A voz poética busca na memória elementos que geram um cenário de "missão cumprida" e o contato com a dita, como no poema que citamos por último, é uma companheira antiga que se aproxima, com uma voracidade quase respeitosa e cheia de dignidade, do sujeito. Em Gullar não há nenhum desejo de reconciliação com a morte, ao contrário, a aceitação de que tudo acaba e de que não há transcendência alguma na qual se apoiar é repetida, poema a poema, nos seus últimos livros: conforme se acentua a certeza do inevitável, mais o sujeito se ressente diante do abismo vazio que o cerca. Fiquemos com a força exemplar do poema "Aprendizado". Nele está marcado o despojamento do autor ao retratar a morte, sobretudo na economia de palavras, na ausência de rodeios retóricos e mistificação, para se deparar com a experiência da morte que o ronda: 


\section{Aprendizado}

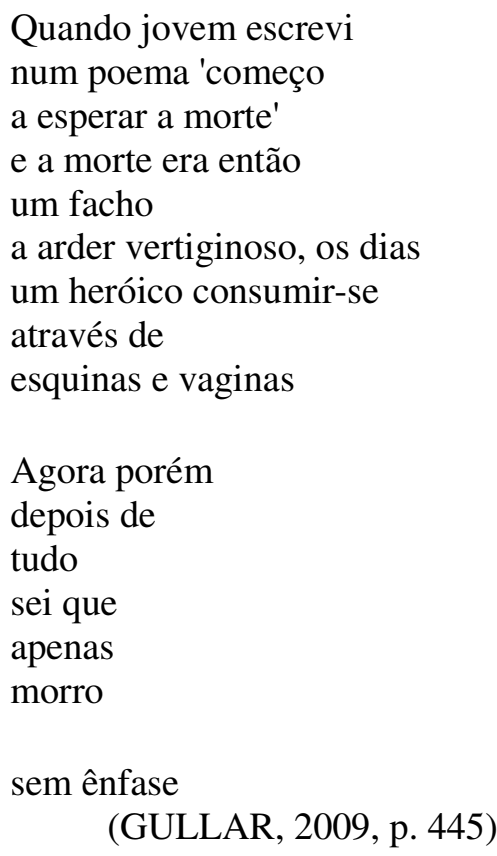

O que é importante esclarecer é que o interesse dos dois autores pela temática relacionada à morte - lembrando ainda que o tema não era de todo estranho à poesia dos autores, apenas se verifica uma recorrência maior e um tratamento mais alongado da questão - merece se interpretado em toda a sua complexidade. Não se trata simplesmente de um mergulho na individualidade, como forma de escapar ao esvaziamento das propostas políticas semeadas nas décadas anteriores, mero efeito interno de uma situação externa desencantada; tampouco o fato pode ser entendido apenas como efeito de uma etapa biográfica, a chegada dos 70 anos, a sensação do fim à espreita dos autores motivando uma ênfase quase obsessiva nestas questões. Uma mediação crítica entre a explicação particularista, biográfica, e o movimento histórico é imprescindível para que alcancemos uma leitura mais interessante e correta.

De uma vez por todas e Campo de Milagres, os dois livros mais recentes de Thiago de Mello, apresentam, portanto, um traço extremamente ambíguo: eles preservam o ethos solidário, de fundo participativo, profetizando ainda suas "auroras", só que não mais simbolizando uma causa política reconhecida, mas sim direitos mais abstratos, uma certo de humanização, nos quais se fala mais em "justiça", "amor", do que em mudança social (e nunca em "revolução"), a fala militante se empenha mais na conservação da floresta Amazônica do que em cultivar uma rebeldia propriamente dita. A crítica social, além de mais evanescente e moralizada, perde espaço em relação aos livros 
anteriores. Em seu lugar, vemos emergir temas de ordem mais íntima, como o encontro amoroso e já examinada preocupação com a morte que, se sempre estiveram presentes em sua produção, agora ganham peso maior ao se desenvolverem com uma menor vigilância do sentimento de culpa que as sufocava em favor de um engajamento mais radical.

A parte de sua poesia mais visivelmente identificável sob o rótulo do "protesto" agora se localiza em capítulos específicos como o "Diário de um brasileiro", em De uma vez por todas, ou sob a orientação drummondiana que organiza "Os do ser e estar no mundo" (capítulo de Campo de Milagres). O que não impossibilita, claro, que o ímpeto participativo esteja também disseminado em outras partes destes livros; a diferença é que o poeta agora trabalha com a separação entre os poemas propriamente questionadores da realidade social brasileira, ou que assim se apresentam, daqueles em que o senso de justiça se envereda pelos rumos da especulação subjetiva, que tratam a mudança e a utopia não como construções eminentemente políticas, mas como um modo de enfrentar o mundo, um atributo fundido em todas as facetas do sujeito lírico e que se confunde com o próprio canto.

Assim, temos de um lado preservado o compromisso com a mudança, a simpatia pelos povos mais sofridos e as múltiplas referências que criam uma "poética da camaradagem" capaz de carregar o leitor carinhosamente pela mão, num diálogo de cumplicidade afetiva. Pois cada vez mais o sujeito se abre, como uma sala de visita, ou uma "praça de convites", para homenagear antigos companheiros, ilustres autores mortos ou humildes personagens da terra onde vive. Do outro lado, seus poemas de denúncia soam como uma necessidade mais ética do que expressiva; valem como pegadas de uma desilusão contida, um vago sentimento de derrota que a voz poética, ao reafirmar uma confiança inabalável no poder da poesia, tenta constituir em vitória, ou, retomando as palavras de Eagleton, uma nostalgia da participação política mais realista em outros tempos, como se deixa subentender num dos poemas de Campo de Milagres:

\section{Confidência}

De tudo ganhei um pouco deste enlouquecido século que se vai e deixa a ternura ameaçada de extinção.

Ganhei flores. Do segredo 
de tantas já me esqueci.

Entre as prendas, guardo marcas

das dores que mereci.

Só me ampara uma certeza:

me dei todo no que fiz.

Comigo se acaba a mágoa

de perder o que mais quis.

(MELLO, 1998, p. 21)

O poema é uma espécie de balanço do sujeito, medindo perdas e ganhos que a vida lhe revelou. O cenário histórico é mencionado com preocupação: ele fala de "um enlouquecido fim de século" que ameaça a ternura de extinção. O tempo é de risco, portanto. Mas se a ternura surge ameaçada pelos males verificados no momento enunciativo do poema, é sinal de que ela ainda existe. O "saldo da vida" buscado nas simplórias redondilhas de seus versos, na cadência singela e rimas simples, contempla lembranças e esperanças. Dores, flores cujo perfume já se perdeu na memória do sujeito e, por fim, um controverso sentimento de missão cumprida, verbalizada no amparo de que "me dei todo no que fiz", trazendo para a subjetividade a redenção da missão não plenamente satisfeita no plano histórico. O desfecho mantém, em construção um pouco mais enigmática, o balanço final das ações: "Comigo se acaba a mágoa/ de perder o que mais quis". A ideia do fim está presente, sinalizando, portanto, a iminência da morte; a perda e a esperança mais íntima se complementam mutuamente neste cenário de calma atribulação do eu poético. O saldo final? É confuso, ambíguo, cheio de nostalgia, mas também carregado de contentamento e consolo.

Pouco depois de retornar do exílio, Thiago de Mello surpreende a todos e decide se transferir para a cidade de Barreirinha, onde passa a viver em contato intenso com a floresta Amazônica, cenário marcante de vários de seus livros, principalmente os escritos em prosa, onde exerce uma forte militância em favor da preservação da floresta, saindo deste seu reduto do mundo apenas eventualmente, para eventos literários, conferências ou lançamento de obras. A distância dos grandes centros intelectuais do país ajuda a explicar, em partes, o silêncio da crítica sobre sua obra, ainda que o poeta mantenha uma constância editorial sólida, publicando, nos últimos anos, duas antologias de poemas e as suas obras completas.

O retorno ao Brasil acaba sendo uma espécie de nova etapa do exílio. Conforme indicamos no capítulo anterior, trata-se de um exílio cumprido agora em casa, na companhia de conhecidos, com a liberdade de sair e voltar do espaço onde nasceu, mas mantendo alguns sinais inequívocos do exilado, confirmando as proposições de Edward Said ao dizer que: “o exílio baseia-se na existência 
do amor pela terra natal e nos laços que nos ligam a ela - o que é verdade para todo exílio não é a perda da pátria e do amor à pátria, mas que a perda é inerente à própria existência de ambos". (SAID, 2003, p. 59).

Thiago de Mello, ao retornar para o isolamento de sua cidade natal, se mantém distante dos grandes centros de debate literário (principais universidades, jornais de maior circulação, polos editoriais), ao mesmo tempo em que sua obra segue tomando um rumo bastante singular dentro das linhas de força da poesia contemporânea, acentuando a solidão que parece acompanhar suas últimas publicações, como expressão de um poeta a descansar mansamente nas margens do grande Amazonas, longe de tudo, relembrando de amigos e episódios da trágica e bela história da América Latina no século XX.

O distanciamento, então, não é apenas geográfico, mas também de afinidade. Incomoda para muitos o fato da obra de Thiago de Mello não se inserir nas linhas mais festejadas da lírica moderna, o que dificulta sua recepção crítica. O contínuo diálogo que ele estabelece com a tradição é sempre medido pelo viés da cumplicidade amiga e nunca pela retomada crítica de um legado; dialoga muito mais com pessoas, com antigos escritores que foram seus amigos, do que efetivamente com obras de referência dentro da literatura brasileira. Para uma crítica literária impregnada pela valorização da negatividade, pelo gosto sutil das citações ecléticas, da despersonalização, das identidades abaladas e uma série de outros elementos já conceituados de antemão, a poesia dócil, cheia de certezas, de Thiago pode ser apressadamente taxada de inconveniente, anacrônica, romântica, desnecessária.

Entretanto, a dificuldade em se analisar esta poética com os recursos que a crítica formulou para a lírica moderna, faz com que em muitos casos a análise exija uma proposta que simplesmente não era a formulada pela obra. Chegando ao ponto de taxá-la como regionalista, unicamente pela coincidência biográfica do poeta ter optado em se recolher a sua Barreirinha, fugindo assim da profusão dos grandes centros formadores de opinião. Evidentemente, este cenário não pode também nos levar ao equívoco presente no outro extremo: o de formular um julgamento complacente de seu alcance artístico, como se a peculiaridade de sua elaboração fosse suficiente para torná-la esteticamente apreciável.

Passando do rol das mudanças para o não menos interessante rol das permanências, veremos que ao menos uma característica se manteve praticamente intacta na passagem de sua poesia pela 
encruzilhada do mundo pós-guerra fria, à nova "desordem" econômica, aos efeitos da globalização neoliberal: a formulação literária da já apresentada "poética da camaradagem”. Com os elementos afetivos, solidarizantes, ternos e cúmplices, os dois últimos livros de Thiago de Mello mantém com o restante da obra um fio de coerência que certamente é o rosto com o qual ficará gravada no capítulo da história literária brasileira que ajudou a construir.

Aliás, o artifício das amizades será até mesmo expandido nos livros mais recentes, com a inserção de recursos novos, como a apresentação de imagens de amigos (fotos em que o autor aparece em cenas de enorme carinho com os amigos que são homenageados nos poemas), retratos de presentes que são mencionados e tornam-se matéria de alguns poemas e servem como ilustração e, mais até, como índices de um realismo cortês cujo desejo maior é transmitir ao leitor uma aura de amizade e confiança no sujeito-poeta-amigo: este interlocutor virtual da poesia de Thiago se trata de um "leitor desconhecido, mas de cuja vida participa meu canto repartido a serviço do amor, lucidamente" (MELLO, 1996, p. 9).

Interessa-nos particularmente esta permanência e suas escolhas textuais - as homenagens, o diálogo íntimo com o leitor, o intertexto menos crítico do que fraternal. Porque é a partir dessa memória pessoal, na qual emergem amigos e cenários, que sua poesia mantém, neste novo contexto de circulação desterritorializada de cultura e capital, uma perspectiva latino-americana de persistência do desejo de integração dos laços.

Com Thiago de Mello vemos se manter, ainda, a esperança de um diálogo. Diferente da obra de Gullar, que, como veremos detalhadamente no próximo item de reflexão, sentirá os impactos do esgotamento do ideal de aproximação, acentuados nos anos 90, já com o adestramento capitalista do mito de Che Guevara, com a morte de Neruda e os duros problemas econômicos enfrentados por Cuba. Na poesia mais recente de Ferreira Gullar, o único espaço de sua obra poética que ainda aglutina a referência à América Latina passa a ser, tanto em Muitas Vozes como no recente Em Alguma Parte Alguma, o vórtice da memória particular do exílio. Em Thiago de Mello, ainda presenciamos na dedicatória de seu livro mais recente, a referência a poetas escritores latino-americanos devidamente assinalados sob o desejo de um pátria maior que os una:

Para Ernesto Cardenal, Eliseo Diogo, Mario Benedetti, Nicanor Parra, Jayme Sabines, Cesar Calvo, Enrique Lihn, Roberto Retamar, Pablo Armando, Jaime Jaramillo Escobar, Adán Méndez, poetas da pátria grande. (MELLO, 1996, p. 4) 
Além das dedicatórias, prefácios e fotografias, que estão, como já foi dito, estrategicamente dispostos como mapas de leitura e complementos de sentido da matéria poética, há, no que se refere a proposta americanista destes dois últimos livros, outras referências espalhadas pelos poemas. Algumas delas já foram levantadas e analisadas nos capítulos anteriores: o poema "O coração latino-americano" - lido por nós como síntese da identidade continental veiculada no interior da obra do poeta - o poema "Segunda declaración de amor", dedicado a Fidel Castro, dentre outros já estudados em capítulo anteriores. Outro exemplo bastante contundente é o poema "O Nemésio", sem dúvida um dos mais comoventes de Campo de Milagres.

Nele é relatada com delicadeza e uma bem medida dose de melancolia os últimos dias do pintor chileno Nemesio Antunez. O pintor fora um dos grandes amigos de Thiago durante sua passagem pelo Chile e já havia sido retratado em dois poemas de Faz escuro mas eu canto, sendo, ao lado de Neruda, umas das figuras mais importantes dessa cadeia de referências e companheirismo que a poesia de Thiago visa criar. Com o câncer do amigo em estágio bastante desenvolvido, o poeta viaja novamente para o Chile já ciente de que uma despedida era inevitável.

Cantei, voz sem tremer: "Soy marinero!"

Ouvi (vi) o refrão no seu olhar, rebrilhando feliz: "me gusta el mar".

Ardiam as estrelas dos seus olhos.

Abri meus braços e cantei de novo:

"Soy marinero", e Nemo me espantou:

respondeu já sem voz: "Me gusta el mar".

Depois sua mão pousou na minha

e me disse sorrindo: "Te esperé".

Isso no entardecer. De madrugada,

Nemesio Antunez voou, pássaro imenso

com suas asas meigas, poderosas,

para o outro lado do rio. Vazio

o cavalete fica do pintor

que gravada deixou todas as cores

do milagre latino-americano.

(MELLO, 1998, p. 83)

Memórias da luta junto a Allende, esperanças de uma América unida e antigas alegrias vão cintilando do diálogo entre o poeta e o pintor, em seu leito terminal. No poema, as várias estratégias e cacoetes utilizados para simbolizar a união entre o continente americano (a citação do espanhol, a apresentação de autores/amigos de pouco acesso por parte do público brasileiro, a defesa de uma integração entre os países) aparecem fundidas densamente no poema, sem o artificialismo de outras 
ocasiões. É como se a força emotiva da perda do amigo unificasse as aspirações ideológicas e as justificasse poeticamente, num resultado estético mais elevado, capaz de comover o leitor que vê, na imagem realista deste amigo (ao lado do poema há a reprodução de uma foto em que o pintor esbanja um elegante e largo sorriso) mais que um símbolo estreito de um continente que mal conhecemos.

Os índices de amizade, o terror e a dignidade presentes nos últimas instantes do artista prostrado na cama, se relacionam liricamente com um desejado diálogo entre os países ali representados: resgatam, na concretude narrativa de seus versos, uma disposição para a solidariedade, na esperança humanamente terna de dividirmos nossas fraquezas e medos, no silêncio inquietante do fim.

\section{4- Entre as ruínas da memória, ruínas de América.}

O contraste observado na comparação entre a poesia de Ferreira Gullar e a poesia de Thiago de Mello revela, dentre outras coisas, a peculiaridade e o isolamento da dicção poética adotada pelo segundo dentro da lírica brasileira contemporânea. Ferreira Gullar imprime em sua obra mais recente um crescente aperfeiçoamento da palavra justa, poética, elaborada em sua máxima densidade e rigidez melódica. A voz de Thiago de Mello é solitária: mantém uma retórica solta, flertando com a prosa, mais apoiada na espontaneidade singela de seus versos do que numa condensação poética rigorosa. Nos últimos livros, Ferreira Gullar eleva a patamares de extremo labor construtivo o tom coloquial que, cada vez mais sofisticado e reflexivo, persiste no cerne de sua expressão. Como resultado concreto destas mudanças, vemos em Muitas Vozes o predomínio de poemas extremamente curtos, como "Manhã de novembro", "O morto e o vivo" e "Reflexão"; outros com requintados ritmos musicais, como "Dança Flamenca", além de referências mais abundantes à certa tradição erudita, citações e diálogos com Rodin, Willemsen, Mallarmé, que até estavam presentes anteriormente ${ }^{74}$, mas que vêm à tona, agora, com uma tensão mais refinada, livre

74 Em seu livro de estreia, A luta corporal, a pena do Gullar crítico de artes plásticas é sentida claramente em vários poemas: na escultura do poema "O Anjo", nos poemas sobre as frutas, verdadeiros quadros de natureza morta, como "As peras" e "As frutas", ou no detalhismo pictórico do poema "Galo galo" e "Galinha". Em Dentro da Noite Veloz o diálogo com a tradição erudita, seja das artes plásticas ou da literatura, é preservado mas encenado como negação. Lembramos, por exemplo, no poema “Agosto 1964", em que o autor se despede de Mallarmé, Rimbaud, relógios lilases, concretismo, neoconcretismo, para se concentrar de vez no cotidiano sofrido das cidades, nos salários 
de compromissos morais ou receios de pedantismo que porventura intercediam na autonomia artística.

As já comentadas mudanças na visão de mundo do escritor deixam entrever a adoção de um discurso calcado no ressentimento político e moldam a sua forma poética de maneira bastante intensa. Não significa necessariamente que, por isso, ela perca alcance crítico ou abandone, cinicamente, sua "função social”. Ao contrário, o que temos é uma migração do seu canal de resistência, com as necessária alterações na postura do sujeito de seus poemas: num mundo cada vez mais alheio à reflexão e mecânico nas relações com as experiências, a arte passa a cumprir papel cada vez mais importante na defesa crítica da humanização plena, sendo mais que nunca necessária. Os poemas de Muitas Vozes, com suas investidas na questão da morte, suas ponderações sobre a arte, seu mergulho na memória e as inquietudes metafísicas que animam a obra, são exemplos decisivos de uma rearticulação da palavra poética.

Durante esta migração de sentidos, as temáticas ligadas ao pensamento latino-americano perdem espaço no rol de assuntos da poesia de Gullar. No plano histórico, a força com que a latinidade irradiou nas letras brasileiras nos anos 60 e 70 já se diluíra, como vimos, na consolidação da globalização neoliberal, sustentada pelos meios de comunicação, cada vez mais sintonizados com a ideologia oficial, inclusive na circulação de suas mensagens, já fortemente adaptadas à condição de produtos globais.

As ligações que sua poesia mais abertamente engajada formulava continuamente entre o Brasil e a América Latina - "aquela pequena cidade latino-americana", ao falar de São Luís do Maranhão, ou “em "Ipanema, na América Latina” - que imprimiam na sua poética uma sólida vertente que pregava a similaridade e fomentava o intercâmbio entre os países, agora deixa de ser evidente. Antes notávamos isso com facilidade nos grandes poemas urbanos de Dentro da Noite Veloz um inequívoco movimento de ampliação da ótica do sujeito, de modo a buscar correlativos e referentes externos, irmanando o drama social percebido na cidade brasileira, ora o Rio de Janeiro onde vive, ora a São Luís da infância. Por sua vez, no tumulto fônico de Muitas Vozes o foco do olhar se inverte. A referência textual à cenários paralelos e simultâneos ("Uma greve em Santiago. Chove na jamaica... A bolsa no Rio fecha em alta ou baixa”) dá lugar a uma visão mais íntima da cidade. Como no poema "Morrer no Rio de Janeiro", no qual a contemplação das teias de agitação, 
banal, prosaica e ruidosa, da cidade suscitam uma reflexão de cunho mais metafísico do que de revolta explícita ou desconforto social.

A decepção com o projeto socialista, tema recorrente em várias entrevistas do autor, resulta numa aceitação mais ou menos crítico do modelo vigente, no caso o capitalismo em seu estágio informatizado, "globalizado". Assim, a defesa de uma consciência terceiro-mundista, antiimperialista e abertamente revolucionária, cede lugar a um cosmopolitismo voltado à tradição literária mais prestigiada, num diálogo acurado, mas preservando algo de impuro, com artistas da mais aplaudida estirpe.

As exceções a este silêncio programático são relativas às escritas da memória. Sem a ambição totalizadora do Poema Sujo, a memória continua sendo matéria importante dos poemas do livro de 1999. Estes poemas exploram passagens biográficas do poeta e problematizam o jogo do lembrar/esquecer, desafiando, ainda que sabidamente em vão, a força corrosiva do tempo. É neles que a América ressurge, não mais colocada em perspectiva, como uma formulação política urgente e sim como um espaço traumaticamente evocado pela memória do sujeito. Em Muitas Vozes e no recentíssimo Em Alguma Parte Alguma, os anos de exílio no Chile retornam à cena, mediados pela distância temporal propiciada pela memória. Como podemos constatar no poema "Queda de Allende":

\section{Queda de Allende}

A luz da manhã era leitosa e não se via o leiteiro na esquina da Carlos Sampaio Desci

com dois litros vazios atravessei o conjunto residencial do outro lado da praça havia uma fila de gente comprando leite e à minha frente uma senhora se dirigia também para lá pensei em bancar o cavalheiro mas o leite era pouco deixei-a para 
trás sem saber que

daquele leite

não haveria de beber

\section{2}

escondi meus escassos

dólares sob a

palmilha do

sapato pus numa

sacola escova e pasta de

dentes e saí para

participar da

resistência mas

na primeira esquina havia

num banca de

jornais uma fila

ouvia-se

longe o matraquear das

metralhadoras aviões

sobrevoavam La Moneda o mundo

desabava e ainda

assim entrei na fila

para comprar cigarros.

3

cheguei à Vila

Olímpica: de uma esquina

soldados atiravam contra uma

fábrica que

resistia

enquanto entre

os soldados e a

fábrica num

terreno baldio um

grupo de rapazes

jogava futebol: quando

os soldados atiravam

eles se abaixavam e

quando o tiroteio cessava

voltavam a jogar.

(GULLAR, 1999, p. 443-444)

O poema está presente em Muitas Vozes. Como bem observa Alfredo Bosi (2004), é o único poema abertamente amparado por um evento histórico, político. É também a referência mais clara 
aos anos de exílio do poeta na América Latina. Embora tematize um acontecimento político e tenha uma referencialidade bastante evidente, não se pode dizer, contudo, que "Queda de Allende" quebre a lógica de distanciamento do engajamento poético - tal como aquele esmiuçado nos livros anteriores - entendida como marca dominante desta nova etapa da poesia do autor. Muito mais do que um posicionamento negativo diante do golpe militar que assassinou Salvador Allende, o que vemos é uma ênfase formal no aspecto da rememoração de acontecimentos testemunhados por esse $e u$ num passado difuso, repleto de névoas e traumas, sem nenhum indício de saudade ou nostalgia.

Os procedimentos literários convergem para esta expressão interiorizada dos acontecimentos, valendo mais a carga íntima que eles despertam do que sua relevância ou eventual dramaticidade do ponto de vista social da história da América Latina. Isso ocorre, sobretudo, pela estratégia de economia de pontuação. A falta de pausas marcadas gera, no tecido poético, um ocultamento entre as fronteiras das frases, embaralhando a sintaxe e exigindo do leitor uma postura de reordenação dos sentidos ali expressados, transmitindo a quem lê uma sensação de desconforto e vertigem análoga à vivida pelo sujeito poético nos momentos de indefinição narrados.

A começar pelas imagens dos primeiros versos, com a luz leitosa da manhã contrastando com a ausência do leite e a necessidade de ir buscá-lo nas longas filas de distribuição. Temos aqui o que pode ser uma referência invertida, altamente negativa, do desfecho do poema "A morte do leiteiro", de Carlos Drummond de Andrade (2002, p. 178-180), cuja imagem final é a da mescla do sangue do trabalhador, torpemente assassinado, com o leite que viria a entregar, formando "um terceiro tom a que chamamos aurora”. A manhã chilena, isto é, a manhã da memória do sujeito, é uma manhã sem leite, farta de sede, e a aurora não se costura no sangue que caíra nas ruas após o golpe já maquinado.

A falta de pontuação exige do leitor um lento processo de separação dos acontecimentos, desembaralhando, ativamente, a sintaxe e a ordem causal-temporal do poema. Isso gera um efeito de mistura, confusão que também é própria do delírio. A matéria recordada vem inundada de fantasmas, reforçando a impressão daqueles dias vividos sob o pânico de ser descoberto pelas autoridades chilenas e entregue para a ditadura brasileira. As situações narradas também cumprem essa mesma função de dilatar a atmosfera obscura da memória traumática, aparentemente solta, flertando com o inconsciente, do sujeito que recorda passagens conturbadas de sua vida, como era também a do contexto lembrado: a senhora que ele deixa para trás na fila, a banca de jornal, os 
jovens interrompendo intermitentemente a partida de futebol para se protegerem dos tiroteios, tudo carrega consigo um tom surreal, uma marca de "absurdo realista". A violência legível nas frestas do discurso, no desejo de resistir, logo cortado pelo desejo banal de comprar cigarros, ou, mais a frente, na fábrica que "resistia" (a palavra é inserida solitariamente num verso, marcando melancolicamente o isolamento dos defensores de Allende).

O núcleo da poética de Gullar, como vemos neste importante poema, se desloca de um prosaísmo mais livre e questionador, revelador dos dramas do sujeito inserido numa dinâmica social injusta, para um coloquialismo depurado, pungente, que encontra nos pequenos objetos um "susto", um "choque" capaz de revelar divagações de ordem subjetiva. Em "Queda de Allende", poema recente, fundado na memória do exílio, não há mais espaço para o olhar perplexo que contemplava, ferido, as ruínas da esperança chilena em "Dois poemas chilenos", contemporâneos ao golpe e analisado no capítulo anterior.

Allende não pode mais ser chamado de amigo, não há abertura para um balanço histórico didatizante, ainda que negativo, ou para a solidariedade diante da primavera adiada pelas forças golpistas. A resistência muda de lugar: não é mais abertamente participante, antes disso é desiludida, ferida em suas convicções coletivas, mas se concentra na defesa do sentir, almeja fazer da poesia uma constante renovação do questionamento, da dúvida, da beleza e da liberdade.

Para tomarmos um contra-exemplo da poesia de Thiago de Mello, citamos o poema "Chile", presente em De uma vez por todas, portanto também inserido nas facetas mais recentes da poesia do autor, sendo também uma rememoração sobre os anos em que viveu no Chile:

\section{Chile}

De tua longa pétala uma gota

de orvalho intacta

perdura no meu peito.

A doce luz da tua primavera

nasce dela, que nunca se evapora.

Mais que gota de pétala, és o mar denso,

brisa da noite, vento de verão,

neve de cordilheira, a lava ardente

e doce da ternura que tua gente

nos âmagos da vida me gravou. 


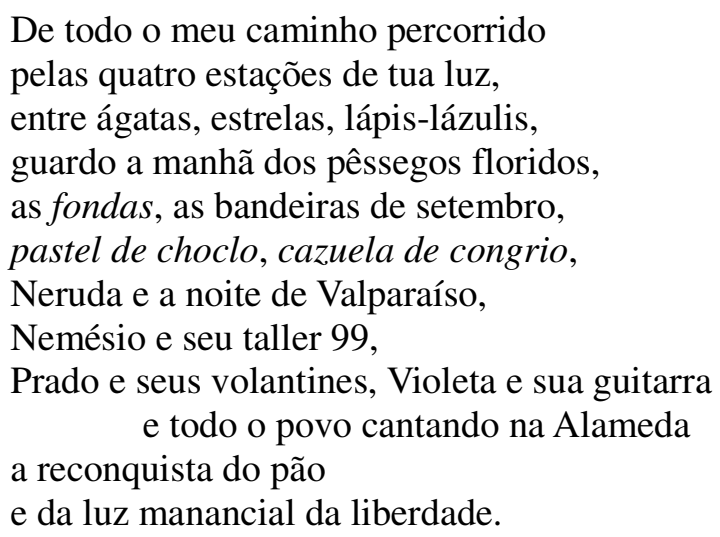

(MELLO, 1996, p. 98-99)

A memória do exílio elege como símbolos dos anos em que passou no Chile a paisagem natural do país (alamedas, oceano, cordilheira, a primavera) e os episódios vividos com seu povo. Novamente emergem no poema figuras latino-americanas já estudadas ao longo do trabalho: Neruda, em imagem estática e simbólica, quase que fundido à noite de Valparaíso; Nemésio Antunez, Violeta (no caso Violeta Parra, importante cantora chilena) e uma ideia de totalidade resumida na imagem eufórica do povo cantando nas ruas "a reconquista do pão". O poema constitui, portanto, um cenário pré-golpe, quando parte do país se irmanava na construção do socialismo.

Embora fragmentada em quadros isolados, como se cada verso guardasse em si experiências e alegrias maiores que a simples descrição narrativa, podemos dizer que não há maiores tensões neste lembrar: as imagens são cristalinas, de uma dicção poética tradicional, farta de metáforas, e fluem no corpo do poema. A postura do sujeito em relação ao país é de cumplicidade e gratidão; pensar no Chile é, para essa voz, constatar "a doce ternura que tua gente/ nos âmagos da vida me gravou". Memórias positivas, que não buscam resgatar os horrores do golpe, antigos ressentimentos e decepções, apenas preservar uma integridade humana e solidária, dócil e benemérita, esta sim deixando escapar uma dose de saudosismo, se não em relação aos anos de exílio, ao menos em relação aos amigos semeados durante este período.

Uma outra mudança em relação ao tratamento do exílio de Gullar pela América Latina pode ser visto em "Volta a Santiago do Chile", já do livro Em Alguma Parte Alguma, de 2010. Nele é enunciada a problemática separação entre o sujeito que viveu a experiência do golpe militar chileno do sujeito que as rememora, passado já muitos anos, bem como entre a cidade agitada dos anos 70 e a pacata Santiago neoliberal: 


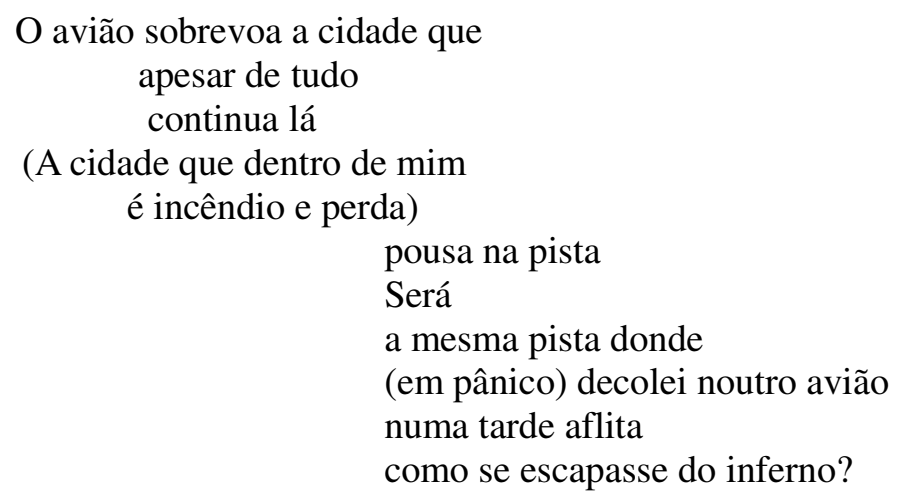

(GULLAR, 2010, p. 119)

O poema constrói duas camadas temporais, a do presente da enunciação, criada a partir da perspectiva área de quem olha, do avião, a cidade de Santiago, com suas avenidas, mercados, praças, o palácio de La Moneda; e o tempo da memória, do passado que visita o sujeito e relembra o terror do exílio, a hostilidade daquela paisagem nos anos em que ali viveu - "pânico", "inferno", indicam a negatividade destas lembranças. Contemplando de cima a cidade, o poeta se indaga sobre o passar do tempo. Num exercício quase heraclitiano, percebe que tudo é diferente, mas a cidade é a mesma:

\section{Estou de volta a Santiago ou não? \\ É esta a cidade onde vivi?}

(GULLAR, 2010, p. 119)

Em cortes secos a ação rapidamente se transfere de espaço: o poeta já está no carro, cruzando pelas ruas da cidade, conhecidas-desconhecidas, como labirintos já visitados mas nem por isso menos enigmáticos:

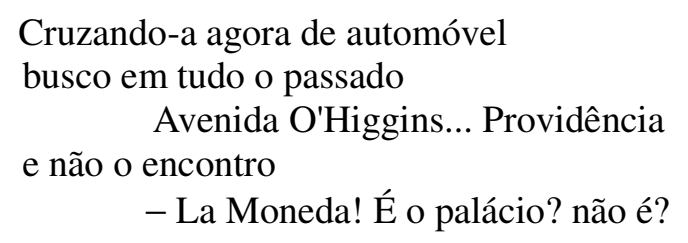

(GULLAR, 2010, p. 119)

"Busco em tudo o passado (...) e não o encontro". A linguagem grave do poema acena para a reconstituição de uma experiência, um sujeito cobrando dos lugares que revisita e das palavras que guardam antigas significações (esperanças? decepções? temores?), mas descobre no silêncio oco que emana dos versos que estes cenários já são outros, vazios e banalmente alegres. Só resta, 
como se verá mais adiante, a certeza dolorosa de que "o passado sou eu” (GULLAR, 2010, p. 120), como se as lembranças e indagações feitas pelo sujeito à cidade só existissem, de fato, em suas próprias experiências, na sua própria capacidade de lembrar e esquecer.

Mais um corte brusco e o sujeito está no hotel:

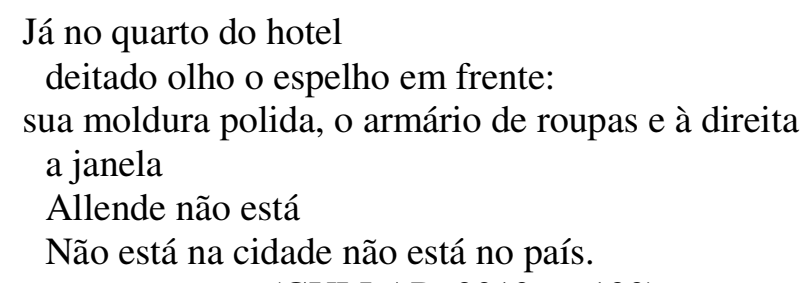

(GULLAR, 2010, p. 120)

A auto-análise, já evidenciada no caráter meditativo das estrofes anteriores, atinge seu grau máximo na imagem do sujeito diante do espelho. Ao encara seu rosto, a concretude da imagem poética indica o momento de reflexão, o sujeito questionando-se, encarando sua personalidade metaforizada no duplo que o reflexo do espelho enfatiza. É no auge do enfrentamento consigo mesmo que Allende novamente retorna como o núcleo desta "Santiago do passado", do passado já perdido, impossível de ser resgatado. Outra vez não há nenhum resquício da intimidade terna com que Gullar se referia a Allende em "Dois poemas chilenos". A presença de Allende é, paradoxalmente, marcada pela ausência: o presidente derrotado simplesmente não está, nem fisicamente, nem com seus projetos, nem com sua resistência mirabolante.

Tudo se desgastou, se transformou, inclusive o homem que reencontra (a cidade, o passado, um fantasma inofensivo de Allende, afinal são a mesma coisa), agora realmente livre, mas que carrega invariavelmente as cicatrizes daqueles anos, inseparáveis de si e daquele espaço por onde passeia; por isso, segue o poema: "La Moneda não é La Moneda”, "Santiago não é Santiago" e por isso, "O passado sou eu".

O contato rápido com as lembranças de Allende demarca as mudanças sociais da cidade. $\mathrm{O}$ presente é agora de segurança, de uma paz conquistada sobre as aspirações derrotadas de sua geração A tranquilidade das alamedas, os hábitos de consumo dos transeuntes, a vida que prosseguiu enquanto o poeta retornou para o Brasil, geraram uma nova realidade, pacata e amena. As feridas do passado são mais pungentes para o sujeito do que para a cidade que seguiu, cicatrizada. Sem fazer qualquer espécie de julgamento político, o poeta chega a constatação, liricamente elaborada nos últimos versos do poema, de que a nova cidade (a triunfante, capitalista, 
com suas mercadorias e shopping centers) é uma espécie de reduto onde a memória não reconhece - nem se reconhece - saudade alguma:

A cidade é agora apenas suas ruas e casas, os supermercados, os shoppings abarrotados de mercadorias.

Nenhum temor, nenhuma esperança maior.

(GULLAR, 2010, p. 121)

Santiago é descrita sem os índices e adjetivos que a aproximaria de uma típica cidade latinoamericana. No lugar da repetida imagem da miséria, temos a referência neutra aos shoppings e a abundância de mercadorias - o exato oposto das filas de distribuição, conforme narradas em “Queda de Allende". A tensão social, as chagas do subdesenvolvimento, a expectativa de mudanças estruturais, o fim da desigualdade, a ascensão triunfante do socialismo, todas referências ao discurso político dos anos 60 são anuladas neste novo tempo/espaço, agora domesticado e amistoso - ao menos com esta fantasia pouco ameaçadora que revestes o objetos de consumo, esta paz ambígua, que pode ser conformismo ou segurança.

Em outros termos, a poesia de Gullar acompanha a mudança da história recente e recupera a consolidação de uma Santiago genérica, típico cenário globalizado, onde a homogeneização e a nivelação capitalista de sua paisagem a transforma num espaço desprovido de identidade, a não ser, repetimos, aquela ferida de Allende e do golpe que o derrubou, a cicatriz guardada na paisagem que se modernizou. Sai a cidade latino-americana, derrotada, para elevação monumental das conquistas estandardizadas do mercado. O dado crucial do poema é que em meio à calmaria, na segurança exuberante do capital, a segurança parece ser conquistada às custas da esperança humana.

Neste cenário completamente pós-utópico, o verso final é um cruzamento implícito entre a paz e contentamento, e entre esperança e desconforto. A definição da Santiago - e que vale para os grandes centros pós-modernos da América Latina - é a de um lugar "sem nenhum temor, sem nenhuma esperança maior". O poeta, porém, já não explica se o saldo desta mudança é positivo ou negativo, não indica se há um preço justo a se pagar pela esperança perdida. Cabe ao leitor, novos atores desta América Latina cada vez mais plural e, quem sabe por isso, mais solitária, fazer as suas contas e descobrir o que nos resta e o que ainda nos falta nestes novos tempos. 


\section{Considerações finais}

O balanço crítico dos ideais comunitários, proposto por esta pesquisa, permite indicar algumas importantes conclusões a respeito da cultura brasileira em uma de suas vertentes mais problemáticas: os diálogos e trânsitos culturais com os países latino-americanos. Tomando como base o recorte histórico escolhido, no caso a segunda metade do século XX, delimitamos dois momentos distintos: os das décadas de 1960 e 1970, no qual predomina um sentimento de euforia e celebração de uma pretensa unidade latino-americana a ser impulsionada no plano simbólico e ratificada na ação; e o das décadas de 1980 e 1990, marcadas por uma crise do discurso utópico e esvaziamento da política, momento de imposição da ideologia neoliberal e de sua faceta globalizadora, cujos princípios mercadológicos se opõem a qualquer aspiração comunitária tal como formulada nas décadas anteriores.

Neste período notamos uma migração do discurso da e sobre a América Latina. As tentativas de desvendar as particularidades do continente tornam-se mais escassas na literatura ao mesmo tempo que se fortalecem linhas de pesquisa acadêmica em torno da temática americanista, seja nos grandes centros universitários da América Latina ou nos Estados Unidos. São cada vez mais abundantes as contribuições destes estudos, com uma rede de cooperação entre pesquisadores e a publicação de trabalhos sob os mais variados enfoques, destacando-se as constantes investidas no manancial teórico dos estudos culturais e pós-coloniais.

A reflexão de cunho universitário tem expandido o conhecimento sobre a latinidade, formulando uma sólida revisão crítica do passado dessas relações, dos textos fundadores e canônicos, bem como de debates contemporâneos que vão da migração às políticas de incentivo à cultura, das demandas das minorias aos resquícios das ditaduras no continente.

No campo das formulações simbólicas, sobretudo literárias, a perspectiva de uma América Latina que compartilha problemas e desafios - econômicos, sociais, políticos, humanos - é cada vez menos visitada pela produção atual. Os vínculos entre os países latino-americanos - vínculos existentes ou a serem construídos - tornaram-se, em certa medida, assunto para especialistas, não mais para poetas. Vale salientar, contudo, que ficou para traz o tempo em que existia uma dicotomia normativa entre o discurso literário e o discurso acadêmico/científico. Até mesmo o padrão de racionalidade, objetividade, isenção e a quimérica ideia de neutralidade científica, têm sido 
constantemente alvos de ataques certeiros de novas abordagens de pesquisa, mais flexíveis e sensíveis às constituições e especifidades culturais. A crítica aos padrões eurocêntricos e a busca por um conhecimento construído a partir das margens são elementos que imprimem à crítica literária e cultural um caráter de combate que guarda ainda certas semelhanças com a "literaturamissão" dos anos 1960 e o heroísmo de algumas de suas peças.

Apesar do constante redimensionamento destas fronteiras enunciativas, ainda são evidentes as diferenças entre uma peça científica, um ensaio, uma tese, um artigo, por mais descentrado e "anti-científico" que se pretenda, e um romance, uma letra de canção ou um poema. A arte se volta, por essência, a outro tipo de conhecimento, mais plástico e simbólico, mais sugestivo e provisório; sua linguagem atua no inconsciente, é ambígua, polissêmica, evoca imagens, gera efeitos diversos e contraditórios. São estes atributos da linguagem literária, radicalizados na linguagem poética, que revestem de interesse o que se produziu na literatura brasileira em torno da latinidade, seja na etapa de euforia e construção utópica, ou na atual etapa de refluxo político e desconfiados lampejos de resistência.

O conjunto de poemas analisados comparativamente durante a pesquisa compõem dois modos de se pensar a América Latina a partir do Brasil, tendo como intenção secundária se somar aos esforços de aproximação e diálogo almejados por parte da intelectualidade do continente num período específico. Se não poderiam, como é de se esperar, formar um conhecimento acabado, coerente e coeso a respeito do que é ser latino-americano, estas obras expressam possibilidades autênticas e, em seus melhores momentos, deixam transparecer a inquietação por trás destes esforços de busca infindável.

Sem dúvidas, as manifestações mais efusivas da latinidade na obra de Ferreira Gullar e Thiago de Mello surgem em um contexto único, bastante favorável e receptivo aos discursos comunitários, dificilmente projetável num futuro próximo. A empolgação do momento histórico e as dramáticas aproximações entre arte e política exigidas no período, explicam não apenas a abundância da temática latino-americana nos livros da época como ajuda compreender os limites estéticos neles observados. Dentre os vários pontos problemáticos comentados ao longo do trabalho, lembremos de alguns: a ênfase exagerada nas similaridades, em detrimento das inúmeras e fecundas diferenças que permeiam a formação das nações do continente; a diluição de algumas tensões, rasuradas por um didatismo algo panfletário em alguns momentos e simplificadores em 
outros; o abuso de algumas metáforas familiares, manejadas para reforçar um parentesco natural e irrecusável entre as diversas culturas latino-americanas.

Tais estratégias discursivas, hoje facilmente identificáveis como empobrecedoras, são mais facilmente identificáveis na poesia de Thiago de Mello, enquanto Ferreira Gullar muitas vezes ultrapassa esses cacoetes retóricos, invertendo-os e subvertendo-os para espremer do âmago de suas contradições um sentido verdadeiramente crítico. Mesmo com estes momentos de intensidade lírica, é possível afirmar que muitas combinações e imagens presentes na obras dos autores estão excessivamente coladas ao contexto que favoreceram seu surgimento, não resistindo à dinâmica das mudanças que ocorreram desde então.

$\mathrm{O}$ ar de anacronismo que paira sobre alguns dos poemas que tematizam a união em torno da identidade latino-americana não os tornam, porém, descartáveis ou meros exemplos de um passado distante, no qual os laços mais solidários e humanos ainda eram desejáveis. Ao contrário, o manejo artificial e simplista de um sentimento americanista mantém sua atualidade por servirem como contraponto simbólico às atuais tendências globalizadoras. Longe de fecharem portas, a leitura destas obras pode abrir janelas em direção a um conhecimento mais fecundo das culturas vizinhas, de suas histórias e o modo como nos relacionamos. A perspectiva em questão, lida neste novo contexto, pode, quem sabe, criar um incômodo contrapeso ao competitivo individualismo contemporâneo e suas novas formas de mercado. Em outras palavras, o extremo clamor por diálogo, contrastado pela atual louvação da autossuficiência, abre margens para uma reflexão mais ajustada sobre o quanto estamos dispostos a encarar espelhos imperfeitos, partidos e repartidos, na árdua missão de sermos menos solitários.

Se não acharmos este meio termo insondável, as experiências poéticas aqui confrontadas talvez mantenham abertas alternativas frente ao eurocentrismo dominante na formação cultural latino-americana e frente à hegemonia norte-americana no cenário da cultura de massas, com seus produtos pré-formatados destinados ao consumo a-crítico. O horizonte do contato se mantém, portanto, digno de ser questionado: seja ele em torno da contorcida geografia latino-americana, com seus muros de língua e silêncio, ou em torno da língua portuguesa, com seus oceanos de ressentimentos, ou das mais recentes perspectivas sul-sul, não menos tortuosas e cheias de armadilhas.

Encontrar um espaço neste novo século, conforme assinala Néstor Garcia Canclini (2008), é 
uma tarefa ainda em aberto para nós, latino-americanos, ainda incrédulos e indecisos sobre o que realmente somos e hoje, diferentemente de 40 anos atrás, inseguros inclusive a respeito do que não somos. Talvez os sonhos e pesadelos do século anterior tenham algo a dizer nessa busca. Como nos autores estudados neste trabalho, as respostas oferecidas são imprecisas, irregulares, mas não raro revelam certa contundência.

O silêncio a respeito da América Latina na literatura brasileira atual é eloquente. Mas os esporádicos ruídos que o ofusca também o são. De Ferreira Gullar e Thiago de Mello entendemos que tais ruídos chegam de um passado mais promissor, desejado e nunca alcançado. São ruínas, enfim. Mas deste chão castigado surgem novas e velhas formulações. Em Gullar, a América Latina se refunda em seu canto, as marcas da memória, recordações de passos perdidos pelo continente vão sendo evocadas num misto de remorso e alivio. Em Thiago de Mello, malgrado o sujeito mantenha o mesmo ethos otimista, idealista, voluntarioso, as redes secundárias de seus versos indicam uma instabilidade que se quer negar. Como diante do amigo, Nemésio Antunez, pintor que expressou "todas as cores do milagre latino-americano", e que vai morrer. Como no poeta que se cala para que o tradutor assuma a infausta missão do diálogo.

Dizer que no século XXI a América Latina continua existindo seria uma conclusão perigosa demais para este trabalho. Perigosa por demasiado óbvia, perigosa por incapaz de ser comprovada. Mas em algum dos anos deste século, em uma grande festa da música latino-americana, por onde trafegava estrelas pops do último verão, se aplaudiu com anacrônico empenho uma canção que remedava - em ritmo de rap modernoso e um videoclip que não se cansava de exibir rostos sofridos de um povo com traços indígenas - os lugares-comuns da latinidade, os mesmo que flamulavam na década 1960, novamente repostos em nova versão. Seu nome: "Latinoamérica". Os ruídos pareciam voltar, sem promessas ou saídas anunciadas. Com um trecho dessa canção fechamos este trabalho, da única maneira digna que uma pesquisa pode terminar: abrindo outras.

Soy el que nace y el día que muere, Con los mejores atardeceres, Soy el desarrollo en carne viva, Un discurso sin saliva, Las caras más bonitas que he conocido, Soy la fotografía de un desaparecido, La sangre dentro de tus venas, Soy un pedazo de tierra que vale la pena, Una canasta con frijoles.

Soy Maradona contra Inglaterra Anotándole dos goles.

Soy lo que sostiene mi bandera, La espina dorsal de mi planeta, en mi cordillera. 
Soy lo que me enseño mi padre, El que no quiere a su patria no quiere a su madre. Soy América Latina un pueblo sin piernas pero que camina. ${ }^{75}$ em 2011. 


\section{Referências Bibliográficas}

\section{- Dos autores estudados}

GULLAR, Ferreira. Toda Poesia. Rio de Janeiro: José Olympio, 2009. . Em Alguma parte Alguma. Rio de Janeiro: José Olympio, 2010.

.Cultura posta em questão. Rio de Janeiro: Civilização Brasileira, 1966.

. Vanguarda e Subdesenvolvimento. Rio de Janeiro: Civilização Brasileira, 1978.

1992. . "A revolução cubana". In: SADER, Emir (org). Por que Cuba? Rio de Janeiro: Revan, . Rabo de Foguete: os anos de exílio. Rio de Janeiro: Revan, 1998.

. Os melhores poemas de Ferreira Gullar. Org. Alfredo Bosi. São Paulo: Global, 2002.

. Argumentação contra a morte da arte. Rio de Janeiro: Revan, 1998.

. Sobre arte, sobre poesia. Rio de Janeiro: José Olympio, 2008.

. Relâmpagos - dizer o ver. São Paulo: Cosac \& Naify, 2003.

. "Bienal Brasil exalta experiência frustrada". Folha de São Paulo, Ilustrada, 30 abr.

1994.

- Ferreira Gullar - Depoimentos a Carlos Eduardo Novaes. Coleção Gente. Rio de Janeiro: Editora Rio, 2003.

. Entrevista à revista Bravo. Edição de março 2009.

. Entrevista à Folha Ilustrada. Folha de São Paulo. 02 de junho de 2010.

MELLO, Thiago de. Vento Geral. Rio de Janeiro: Civilização Brasileira, 1984.

. Num campo de margaridas. Rio de Janeiro: Civilização Brasileira, 1986.

. De uma vez por todas. Rio de Janeiro. Civilização Brasileira, 1996.

. Campo de Milagres. Rio de Janeiro. Bertrand Brasil, 1998. 
. Os melhores poemas de Thiago de Mello. São Paulo: Global, 2009.

. Poesía de Thiago de Mello. Trad. Pablo Neruda. Havana: Casa de las Américas, 1977.

. Poemas preferidos do autor e seus leitores. Rio de Janeiro: Bertrand Brasil, 2008.

. Poetas da América de canto castellano. São Paulo: Global, 2011.

. Entrevista a José Castello. In:http://www.revista.agulha.nom.br/castel14.html.

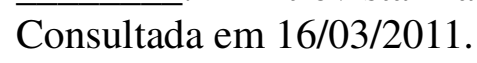

$\overline{16 / 03 / 2011 .}$

Entrevista a Lêdo Rivas. In: http://www.revista.agulha.nom.br/rivas.html Consultada em

\section{- Sobre os autores}

ARRIGUCCI, Davi. “Tudo é exílio”. Jornal de Resenhas. Folha de São Paulo, novembro de 1998. . "O silêncio e Muitas Vozes". In: Folha de São Paulo, 12/06/1999.

BOSI, Alfredo. "Roteiro do poeta Ferreira Gullar”. In: Céu Inferno. São Paulo: Duas Cidades, 2004.

BRAIT, Beth. Literatura comentada/ Ferreira Gullar. São Paulo: Abril educação, 1981.

CADERNOS DE LITERATURA BRASILEIRA: Ferreira Gullar. Instituto Moreira Salles, São Paulo, nº 6, set. 1998.

CAMENIETZKI, Eleonora Ziller. Poesia e Política: a trajetória de Ferreira Gullar. Rio de Janeiro: Revan, 2006.

CONY, Carlos Heitor. "De uma vez por todas". Disponível no site: http://www.revista.agulha.nom.br/cheitor01c.html. Consultado em 16/03/2011.

FORTUNA, Felipe. Os enganos da utopia. In: Suplemento Idéia. Jornal do Brasil. 27/12/1986.

GIORGI, Artur. V. "Nascer, exílio”. In: Anais do Simpósio Fazendo Gênero 9. 23-26 de agosto de 2010 .

GUTKOSKI, Cris. "Estrutura da fuga do exílio em Ferreira Gullar”. Revista letras e letras. Vol. 6, Uberlândia, 2007.

LAFETÁ, José Luís “Traduzir-se”. In: Dimensão da noite. São Paulo: Editora 34, 2007. 
_. "Dois pobres, duas medidas". In: A Dimensão da Noite: Editora 34, 2007.

LINS, Álvaro. "Silêncio, Palavra e Arte Poética". In: MELLO, T. Vento Geral. Rio de Janeiro: Civilização Brasileira, 1984. p. 25.

MERQUIOR, José Guilherme. “A volta do poema”. In: Crítica 1964-1989. Rio de Janeiro: Nova Fronteira, 1990.

MONTENEGRO, O. “...A linguagem do verso”. In: MELLO, T. Vento Geral. Rio de Janeiro: Civilização Brasileira, 1984.

MORAES, Vinícius. "Poema sujo de vida”. Machete: Rio de Janeiro, 1977.

MOURA, George. Ferreira Gullar - Entre o espanto e o poema. Série Perfis do Rio. Rio de Janeiro: Relume-Dumará, 2001.

NERUDA, Pablo. "Desde que Thiago llegó a Chile...". In: MELLO, Thiago de. Vento Geral. Rio de Janeiro: Civilização Brasileira, 1984.

NETO, Miguel S. "Poeta à moda antiga". Disponível no sítio: http://www.revista.agulha.nom.br/msanches28.html. Consultado em 16/03/2011.

PIGNATARI, Decio. “Inimigos Íntimos”. Folha de São Paulo, 12/06/2007

PINTO, Z. “Thiago de Mello: de uma vez por todas, agora.”. Disponível no sítio http://www.revista.agulha.nom.br/zpinto01c.html . Consultado em 16/03/2011.

. “Thiago na luz de Thiago: 45 anos de ternura e poesia”. Disponível no sítio: http://www.revista.agulha.nom.br/zpinto02c.html. Consultado em 16/03/2011.

SECCHIN, Antonio Carlos."A luta corporal". In: Poesia e desordem. São Paulo: Topbooks, 1996

VILLAÇA, Alcides. A poesia de Ferreira Gullar. Tese de Doutoramento. FFLCH-USP. São Paulo, 1984.

Olympio, 1999.

"Em torno do Poema Sujo". Prefácio In: Poema Sujo. $7^{\circ}$ Edição. Rio de Janeiro: José

\section{- Bibliografia Geral}

ABDALA JR. Benjamin. Literatura, História e Política. São Paulo: Ateliê, 2007. 
. De vôos e ilhas. São Paulo: Ateliê, 2003.

. Incertas relações: Brasil-Portugal no século XX. São Paulo: Senac, 2003.

. \& SCARPELlI, M. (org). Portos Flutuantes: trânsitos ibero-afro-americanos. São Paulo: Ateliê, 2004.

ALONSO, Cecilia Laura. Reflexo brasileiro em olhos mexicanos: o Brasil em MONTERREY, correo literario de Alfonso Reyes. Dissertação de mestrado. Universidade Federal Fluminense. Instituto de Letras, 2006.

ANDERSON, Benedict. Nação e consciência nacional. São Paulo: Ática, 1989.

ANDRADE, Carlos Drummond de. Nova Reunião. Rio de Janeiro: José Olympio, 1983. . Antologia poética. Rio de Janeiro: Record, 2002.

AZEVEDO, Isabel Cristina Alencar de. "Revista Civilização Brasileira (1965-1968): produção cultural em revista". Dissertação de mestrado. Rio de Janeiro: Instituto de Letras, UFRJ, 1999.

BANDEIRA, Manuel. Libertinagem \& Estrela da Manhã. Rio de Janeiro: Nova Fronteira, 2000.

. "Perdi a Fé e a esperança no Brasil". Entrevista a Thiago de Mello, Comício, 1:23, Rio de Janeiro. In: ANTELO, Raúl. Literatura em revista. São Paulo: Ática, 1984.

BAUMAN, Zigmunt. Comunidade: a busca por segurança no mundo atual. Trad. Plínio Dentzien Rio de Janeiro: Jorge Zahar, 2005.

Zahar, 1999.

Globalização: as consequências humanas. Trad. Marcus Penchel. Rio de Janeiro: Jorge

BENDA, Julien. La Trahison des Clercs. Paris, Grasset, 1975.

BENJAMIN, Walter. Magia e técnica, arte e política. Trad. Sergio Paulo Rouanet. São Paulo: Brasiliense, 1996.

BLOCH, Ernest. O Princípio Esperança. Vol. I. Trad. Nelio Schneneider. Rio de Janeiro: Contraponto, 2005.

BOSI, Alfredo. Céu Inferno. São Paulo: Duas Cidades, 2004. . O Ser e o Tempo da poesia. São Paulo: Cia. Das Letras, 2000.

BURGER, Peter. "O declínio da Era Moderna”. Trad. Heloísa Jahn. In: Novos Estudos Cebrap, no20, 1988, p. 81-95. 
CAMILO, Vagner. Da rosa do povo à rosa das trevas. São Paulo: Ateliê, 2001.

CANCLINI, Néstor García. Latino-americanos à procura de um lugar neste século. Trad. Sérgio Molina. São Paulo: Iluminuras, 2008.

CANDIDO, Antonio. "Literatura e Subdesenvolvimento". In: Argumento. Rio de Janeiro: Paz e Terra, 1973.

. Formação da Literatura Brasileira. São Paulo: EDUSP, 1975.

. Literatura e sociedade. São Paulo: Nacional, 1985.

CASTAÑEDA, Jorge. Che Guevara: a vida em vermelho. Trad. Bernardo Joffily. São Paulo: Cia. Das Letras, 1997.

DALCASTAGNÉ, Regina. O espaço da dor: o regime de 64 no romance brasileiro. Brasília: ED. UNB, 1996.

DIAS, Luiz Francisco. Os sentidos do idioma nacional. Campinas: Pontes, 1996.

EAGLETON, Terry. As ilusões do pós-modernismo. Trad. Elizabeth Barbosa. Rio de Janeiro: Jorge Zahar, 1998.

FERNANDES, Florestan. Da guerrilha ao socialismo: a Revolução Cubana. São Paulo: T. A. Queiroz, 1979. . Mudanças sociais no Brasil. São Paulo: Difel, 1974.

FREDERICO, Celso. “A Política Cultural dos Comunistas". In: História do Marxismo no Brasil. Vol. III. Campinas: Unicamp, 1998.

FRIEDRICH, Hugo. Estrutura da lírica moderna. Trad. Marise M. Curioni e Dora F. da Silva. São Paulo: Duas Cidades, 1978.

GALEANO, Eduardo. As veias abertas da América Latina. Trad. Galeano de Freitas. Rio de Janeiro: Paz e Terra, 1990.

GINZBURG, Jaime. “A literatura contra o estado em 1968: política e exclusão em Clarice Lispector”. In: Via Atlântica, v. 12, p. 133-139, São Paulo, 2009.

. "Memória da ditadura em Caio Fernando Abreu e Luís Fernando Veríssimo".

Letterature d'America, v. 113, p. 95-110, 2008.

HALL, Stuart. A identidade cultural na pós-modernidade. Trad. Tomás Tadeu da Silva e Guaracira Lopes Louro. Rio de Janeiro: DP\&A Editora, 1999. 
HAMBURGER, Michael. A verdade da poesia. Trad. Alípio Correia de Franca Neto. São Paulo: Cosac \& Naify, 2007.

HOSBSBAWM, Eric. Era dos Extremos: o breve século XX (1914-1991). Trad. Marcos Santarrita. São Paulo: Cia. Das Letras, 2010.

HOLLANDA, Heloísa Buarque. Impressões de Viagem. Rio de Janeiro: Aeroplano, 2004.

JOHNSON, Randal. “A dinâmica do campo literário brasileiro (1930-1945)”. Revista USP. São Paulo, jun-ago 1995, p. 164-181.

LAFETÁ, João Luís. 1930: a crítica e o modernismo. São Paulo: Duas Cidades, 1974.

LOGUERCIO, E. A. "Pan-americanismo versus latino-americanismo". Tese de mestrado. São Paulo: FFLCH, 2007.

LOPEZ, Matias. "Ideologia e utopia no Chile: os usos sociais do exílio e da arte". In: Cad. De Pesq. Interdisc. Em Ci-S. Florianópolis, nº 98, jan-jun 2010.

LOURENÇO, Eduardo. A nau de Ícaro. Lisboa: Gradiva, 1999.

LOYOLA, Hernán. Ser y morir en Pablo Neruda. Santiago: Ed. Santiago, 1997.

MÁRQUEZ, Gabriel García. Eu não vim fazer um discurso. Trad. Eric Nepomuceno. Rio de Janeiro: Record, 2011.

MENDES, J. M. "O desafio das identidades". In: SANTOS, B. S. A globalização e as ciências sociais. São Paulo: Cortez, 2002

MICELI, Sérgio. Intelectuais e Classes Dirigentes no Brasil (1920-1945). São Paulo: Difel, 1979.

MORAES, Marco Antônio de. (org). Correspondência Mário de Andrade \& Manuel Bandeira. São Paulo: Edusp, 2000.

MORAES, Vinícius de. História Natural de Pablo Neruda: uma elegia que vem de longe. São Paulo: Cia. Das Letras, 2006.

Livro de sonetos. Rio de Janeiro: Sabiá, 1967.

MOURA, Murilo Marcondes. Três poetas brasileiros e a Segunda Guerra Mundial: Carlos Drummond de Andrade, Murilo Mendes, Cecília Meireles. Tese de Doutoramento. São Paulo: FFLCH-USP, 1998.

NAPOLITANO, Marcos. "MPB: a trilha sonora da abertura política". In: Estudos Avançados USP, vol. 24, nº 69, São Paulo, 2010. 
NERUDA, Pablo. Canto General. Madrid: Cátedra, 1992.

. Confesso que vivi. Trad. Olga Savary. Rio de Janeiro: Difel, 1977

. Livro das Perguntas. Trad. Ferreira Gullar. São Paulo: Cosac Naify, 2009.

PELLEGRINI, Tânia. "Ficção brasileira contemporânea: ainda a censura?". In: Acta Sciencitarium, Maringá, nº 23, p. 79-86, 2001.

PERRONE-MOISÉS, Leyla. Vira e Mexe Nacionalismo. São Paulo: Cia das Letras, 2007.

RAMA, Ángel. Literatura, cultura y sociedad en América Latina. Montevideo: Trilce, 2006.

SAID, Edward. Representações do intelectual. Trad. Milton Hatoum. São Paulo: Cia. das Letras, 2002.

. "Reflexões sobre o exílio". In: Reflexões sobre o exílio e outros ensaios. Trad. Pedro Maia Soares. São Paulo: Cia. Das Letras, 2003

SALERNO, Nicolás. "Neruda: sus críticos y sus biografos". IN: Estudios Públicos Chilenos, Santiago, 2004.

SANTÍ, Enrico Mario. "Introducción”. In: NERUDA, Pablo. Canto General. Edición de Enrico Mario Santí. Madrid: Cátedra, 1992.

SARTRE, Jean-Paul. Que é a literatura? São Paulo: Ática, 1989.

SCHWARZ, Roberto. "Cultura e política 1964-169". In: O pai de família e outros estudos. Rio de Janeiro: Paz e Terra, 1978.

. Sequências brasileiras: ensaios. São Paulo: Cia. Das Letras, 1999.

SELIGMANN-SILVA, Márcio Orlando (org). História, memória, literatura. O testemunho na era das catástrofes. Campinas: Ed.Unicamp, 2003.

Sicard, Alain. El pensamiento poético de Pablo Neruda. Madrid: Gredos, 1981.

SIMON, Iumna. "Esteticismo e Participação: as vanguardas poéticas no contexto brasileiro (19541969)". In: Novos Estudos Cebrap, n 26, março de 1990.

SOUZA, Eneida Maria de. Crítica Cult. Belo Horizonte: Editora UFMG, 2007.

SOUZA, Raquel. S. Convergências e Divergências: revistas literárias em perspectiva. Tese de Doutoramento. Universidade de São Paulo. Faculdade de Filosofia Letras e Ciências Humanas, 2008. 
SUBIRATS, Eduardo. A penúltima visão do paraíso: ensaios sobre memória e globalização. São Paulo: Studio Nobel, 2001.

TEITELBOIM, Volodia. Neruda. Santiago: Editorial Sudamericana, 1996.

VAlleJO, Cesar. Poesía completa de Cesar Vallejo. Trad. Thiago de Mello. Rio de Janeiro: Philobiblion, 1985.

WITKÓVSKI, A. "L'amitié, le communisme, l'écriture. Pablo Neruda et Jorge Amado" In: ABADALA, B. \& SCARPELLI, M. Portos Flutuantes: trânsitos ibero-afro-americanos. São Paulo: Ateliê, 2004.

ZANETTI, S. "Modernidad y religación: una perspectiva continental (1880-1916)”. In: PIZARRO, Ana. América Latina: palavra, literatura e cultura. Vol. 2. Campinas: UNICAMP, 1993. 